SILAS CARDOSO DE SOUZA

\title{
AS ENTIDADES FECHADAS DE PREVIDÊNCIA COMPLEMENTAR ENQUANTO INSTRUMENTOS DE ATUAÇÃO DO ESTADO NA ECONOMIA
}

Orientador: Prof. doutor Luís Fernando Massoneto

$$
\text { DisSERTAÇÃo DE MESTRAdo }
$$

FACUldAdE DE DiREITo dA UNIVERSIDAdE DE SÃo PAUlo

SÃo PaUlo 


\section{AS ENTIDADES FECHADAS DE PREVIDÊNCIA COMPLEMENTAR ENQUANTO INSTRUMENTOS DE ATUAÇÃO DO ESTADO NA ECONOMIA}

Dissertação apresentada à Banca

Examinadora do Programa de Pós Graduação em Direito da Universidade de São Paulo, como exigência parcial para obtenção do título de Mestre em Direito, na área de concentração Direito Econômico, sob a orientação do Professor Luís Fernando Massoneto.

Faculdade de Direito da Universidade de São Paulo São Paulo 


\title{
AS ENTIDADES FECHADAS DE PREVIDÊNCIA COMPLEMENTAR ENQUANTO INSTRUMENTOS DE ATUAÇÃO DO ESTADO NA ECONOMIA
}

\begin{abstract}
Dissertação apresentada à Banca
Examinadora do Programa de Pós

Graduação em Direito da Universidade de São Paulo, como exigência parcial para obtenção do título de Mestre em Direito, na área de concentração Direito Econômico, sob a orientação do Professor Luís Fernando Massoneto.
\end{abstract}

Data de Aprovação:

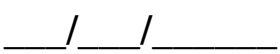

Banca Examinadora:

Prof. Dr. Luís Fernando Massoneto (Orientador) - FDUSP 


\section{AGRADECIMENTOS}

Agradeço à minha família, em especial à minha mãe, Norma, meu pai, José Carlos, e à minha irmã, Yasmin, pelo apoio, amor e carinho de todos estes anos de convivência. Agradeço pela compreensão de quem, já convivendo a distancia há 8 anos, deu mais demonstrações de compreensão ao longo deste último período, no qual tivemos que privar de momentos juntos para a finalização deste trabalho.

Agradeço ao meu orientador, Luís Fernando Massoneto, pela sua receptividade ao meu projeto inicial, pela sua abertura permanente ao diálogo, pelas reuniões proveitosas nestes três anos, por mostrar os caminhos e fazer apontamentos ao longo de todo este trabalho. Sem dúvida, o amadurecimento de ideias inicialmente incipientes não seria possível sem a sua valiosa orientação. Aos professores Alessandro Octaviani e Úrsula Dias Peres agradeço pelas importantes sugestões na banca de qualificação.

Ao Pedro Salomon agradeço pela revisão meticulosa do trabalho. Ao Ivan Candido da Silva de Franco, ao Flavio Marques Prol e ao Francisco Brito Cruz agradeço pelas conversas que também ajudaram a dar forma a esta dissertação. Ao Ivan agradeço ainda por ter sido, durante estes três anos, o amigo de todas as horas, para todos os assuntos, o melhor amigo. À Aline Viotto, companheira de mestrado, agradeço por compartilhar de todas as angústias da caminhada.

Ao Ministro Gilberto Carvalho, figura extraordinária com quem tive a oportunidade de conviver durante 2 anos e meio, agradeço por ensinar, pelo exemplo, a solidariedade, a fraternidade, a opção pelos pobres, e por renovar a crença na luta e na organização política como instrumentos de construção de uma sociedade mais justa e igualitária.

A Diogo de Sant'ana e Vanessa Dolce Faria, meus chefes e amigos, agradeço não só pela compreensão durante as minhas ausências em Brasília, mas sobretudo pelo apoio e incentivo a este projeto de crescimento acadêmico.

Aos amigos de Salvador e São Paulo, Caio Santiago, Flavia Annenberg, Guilherme Giufrida, João Dias Turchi, Jonnas Esmeraldo, José Carlos Callegari, Julia Britto, Laís Gomes, Leonardo Martins, Lucas Amoedo, Luiz Felipe Ramos, Otavio Bessa, Pedro Muller, Rafaela Barbosa, Renan Kalil, Rodrigo Campos, Saylon Pereira, Tulio Alencar, Vanessa Mazzafera, Veridiana Alimonti, agradeço simplesmente pela amizade, essa que é a mais bela das quatro estações da terra (Françoise Hardy). 
Aos amigos de Brasília, em especial Ricardo Leite Ribeiro e Marcos Rogério, agradeço pelo acolhimento na cidade, por me mostrar o caminho das tesourinhas entre as quadras, por me apresentar à vida na secura do cerrado. No planalto central, fiz outras grandes amizades com muita gente boa, querida, competente, com brilho nos olhos e vontade de mudar o país. Gente que me propiciou um crescimento pessoal incrível.

Gente como Aline Souza, Ana Tulia, Andre Calixtre, Bianca dos Santos, Danilo Bertazzi, Duda Cintra, Eduardo Paiva, Fanie Miranda, Fernanda Machiaveli, Fernanda Marangoni, Fernanda Papa, José Lopes Feijóo, Laís Lopes, Lecio Costa, Lucas Maciel, Marcelo Chilvarquer, Marcia Blank, Maria Victoria Hernandez, Melissa Mestriner, Miraci Lopes, Nathalia Ribeiro, Patrick Mariano, Renata Antão, Sabrina Dourigon, Severine Macedo, Thor Ribeiro, Verner Pereira, Victor Pimenta, Vinicius Carvalho, Vladmir Sampaio e Yuri Logrado.

Por fim, mas não menos importante, agradeço a todos os homens e mulheres que militaram no Fórum da Esquerda, coletivo estudantil da Faculdade de Direito da USP, ao qual eu devo a minha formação política e alguns dos melhores anos da minha vida. 


\section{RESUMO}

Com as transformações ocorridas nas últimas décadas do século XX, notadamente a expansão financeira pela qual passou o capitalismo, o enfraquecimento fiscal dos Estados nacionais e o questionamento aos sistemas de previdência pública por repartição, ganham importância em todo o mundo os fundos de pensão. Estes fundos, ao lado de outros investidores institucionais, como seguradoras e fundos de investimentos, passam a cumprir papel central no mercado acionário e também no mercado de títulos públicos e privados. Com o objetivo de realizar lucros para pagar benefícios de aposentadoria para os seus participantes, os fundos de pensão arrecadam e concentram poupança privada pulverizada, transformando-a em um ativo poderoso. No Brasil, as Entidades Fechadas de Previdência Complementar - nomenclatura jurídica dos fundos de pensão - possuem um total de 702 bilhões de reais em ativos, que se concentram nas três maiores entidades do país: Previ, Petros e Funcef. Em comum, estes três fundos têm o fato de serem patrocinados por empresas estatais, o que, pela legislação vigente, dá ao Poder Executivo a competência de indicar metade de seus dirigentes, incluindo o seu presidente que possui voto de desempate. O presente trabalho pesquisou o papel que estas três EFPCs cumprem enquanto instrumento de atuação do Estado no domínio econômico, especialmente para o provimento de fundos para o desenvolvimento. Para isso, primeiramente, o estudo explora o movimento de expansão financeira do capitalismo e a crise no padrão de desenvolvimento brasileiro. Depois, investiga de maneira sistemática o arcabouço jurídico que regula os fundos de pensão; e, por fim, analisa a alocação dos seus investimentos e o perfil dos seus dirigentes.

\section{Palavras-chave}

Fundos de Pensão, Previdência Complementar, Financeirização, Desenvolvimento, Direito Econômico. 


\begin{abstract}
With the changes occurred in the last decades of the twentieth century, notably the financial expansion that has occurred in capitalism, the fiscal weakening of national states and the questioning of the public pension "Pay as You Go" systems, the pension funds increases their importance worldwide. These funds, along with other institutional investors, such as insurance companies and investment funds, started to fulfill a central role in the stock market and also in the public and private securities market. In order to make profits to pay retirement benefits to its participants, pension funds collect and concentrate spread private saving, transforming it into a powerful asset. In Brazil, the Closed Pension Funds Entities - Legal classification of pension funds - have a total of 702 billion reais in assets, which are concentrated in the three largest country's entities: Previ, Petros and Funcef. In common, these three funds are sponsored by state-owned enterprises, which, by Law, gives the Executive Branch the power to appoint half of its leaders, including the President, who has the casting vote. This study investigated the role that these three EFPCs meet as state action instrument in the economic field, especially for the provision of funds for development. To achieve this, we studied the movement of financial expansion of capitalism, the crisis in the Brazilian development pattern and the whole legal framework that regulates the pension funds, to, then, move to an analysis of the allocation of its investments and the profile of its leaders.
\end{abstract}

\title{
Keywords
}

Pension Funds, Complementary Pension System, Financial Expansion, Development, Economic Law. 


\section{LISTA DE GRÁFICOS}

Gráfico 1 - Ativos EPFCs (em bilhões de reais)

Gráfico 2 - Ativos das maiores EFPCs (em bilhões de reais)

Gráfico 3 - Evolução dos investimentos das EFPCs (em \% do total) 


\section{LISTA DE TABELAS E QUADROS}

Tabela 1 - Indicadores da Economia Mundial

Tabela 2 - Carga Tributária Bruta e Líquida (em \% do PIB)

Tabela 3 - Dívida Externa Brasileira (em US\$ milhões)

Tabela 4 - Principais limites de alocação por modalidade de investimento das EFPCs

Tabela 5 - 10 maiores Entidades Fechadas de Previdência Complementar

Tabela 6 -Empresas com participação paraestatal

Tabela 7 - Composição acionária da Vale

Tabela 8 - Empreendimentos grupo Invepar

Tabela 9 - Composição dos investimentos das EFPCs - Junho/2014

Tabela 10 - Composição carteira Previ por classe de investimento (em bilhões de reais)

Tabela 11 - Composição carteira Petros por classe de investimento (em bilhões de reais)

Tabela 12 - Composição carteira Funcef por classe de investimento (em bilhões de reais)

Tabela 13 - Empresas Participadas Previ

Tabela 14 - Participações acionárias Petros (valores em milhões de reais)

Tabela 15 - FIPs participados por Previ, Petros e Funcef

Quadro 1 - Presidentes da Previ

Quadro 2 - Presidentes da Petros

Quadro 3 - Presidentes Funcef 


\section{LISTA DE SIGLAS E ABREVIATURAS}

ABRAPP - Associação Brasileira das Entidades Fechadas de Previdência Complementar

ABVCAP - Associação Brasileira de Private Equity e Venture Capital

ALL - América Latina Logística

APCEF - Associação do Pessoal da Caixa Econômica Federal

Art. - Artigo

BANDES - Banco de Desenvolvimento do Governo do Estado do Espírito Santo

BANESPREV - Fundo Banespa de Seguridade Social

BB - Banco do Brasil

BNDE - Banco Nacional de Desenvolvimento Econômico

BNDES - Banco Nacional de Desenvolvimento Econômico e Social

BNDESPAR - BNDES Participações S/A

BRF - Brasil Foods

CAP - Caixa de Aposentadoria e Pensões

CEF - Caixa Econômica Federal

CEPAC - Certificados de Potencial Adicional de Construção

$\mathrm{CF}$ - Constituição Federal

CGPC - Conselho de Gestão da Previdência Complementar

CLT - Consolidação das Leis do Trabalho

CMN - Conselho Monetário Nacional

CNPC - Conselho Nacional de Previdência Complementar

CNSP - Conselho Nacional de Seguros Privados

CRPC - Câmara de Recursos da Previdência Complementar

CUT - Central Única dos Trabalhadores

CVM - Companhia de Valores Mobiliários 
CVRD - Companhia Vale do Rio Doce

DARPA - Defense Advanced Research Projects Agency

DEM - Democratas (Partido político)

EAPC - Entidade Aberta de Previdência Complementar Aberta

EC - Emenda Constitucional

EFPC - Entidade Fechada de Previdência Complementar

EMBRAPA - Empresa Brasileira de Pesquisa Agropecuária

EUA - Estados Unidos da América

FAT - Fundo de Amparo ao Trabalhador

FDA - Fundo de Desenvolvimento da Amazônia

FDCO - Fundo de Desenvolvimento do Centro-Oeste

FED - Federal Reserve System

FENAE - Federação Nacional das Associações do Pessoal da Caixa Econômica Federal

FGTS - Fundo de Garantia por Tempo de Serviço

FGTS - Fundo de Garantia por Tempo de Serviço

FGV - Fundação Getúlio Vargas

FHC - Fernando Henrique Cardoso

FI-FGTS - Fundo de Investimento do Fundo de Garantia do Tempo de Serviço

FINEP - Financiadora de Estudos e Projetos

FIP - Fundo de Investimento em Participações

FMI - Fundo Monetário Internacional

FMIEE - Fundos de Investimento em Empresas Emergentes

FNDE - Fundo de Desenvolvimento do Nordeste

FORLUZ - Fundação Forluminas de Seguridade Social

FUNCEF - Fundação dos Economiários Federais

FUNCESP - Fundação CESP 
FUNPRESP - Fundação de Previdência Complementar do Servidor Público Federal FUNPRESP-EXE - Fundação de Previdência Complementar do Servidor Público Federal do Poder Executivo

FUNTTEL - Fundo para o Desenvolvimento Tecnológico das Telecomunicações

HTTP - Hypertext Transfer Protocol

IAP - Instituto de Aposentadoria e Pensões

INPS - Instituto Nacional da Previdência Social

INSS - Instituto Nacional de Seguridade Social

IPREM - Instituto de Previdência Municipal de São Paulo

ISSB - Instituto de Serviços Sociais do Brasil

LC - Lei Complementar

LOPS - Lei Orgânica da Previdência Social

MPAS - Ministério da Previdência e Assistência Social

MPS - Ministério da Previdência Social

OCDE - Organização para a Cooperação e Desenvolvimento Econômico

OPEP - Organização dos Países Produtores de Petróleo

ORTN - Obrigação Reajustável do Tesouro Nacional

P\&D - Pesquisa e Desenvolvimento

PAC - Programa de Aceleração do Crescimento

PAEG - Plano de Ação Econômica do Governo

PASEP - Programa de Formação do Patrimônio do Servidor Público

PETROS - Fundação Petrobrás de Seguridade Social

PIB - Produto Interno Bruto

PIS - Programa de Integração Social

PIS - Programa de Integração Social

PITCE - Política Industrial, Tecnológica e de Comércio Exterior 
PLN - Projeto de Lei do Congresso Nacional

PLP - Projeto de Lei Complementar

PMDB - Partido do Movimento Democrático Brasileiro

PND - Plano Nacional de Desenvolvimento

PPA - Plano Plurianual

PPP - Parceria Público-Privada

PREVI - Caixa de Previdência dos Funcionários do Banco do Brasil

PREVIC - Superintendência Nacional de Previdência Complementar

PSDB - Partido da Social Democracia Brasileira

PT - Partido dos Trabalhadores

PTB - Partido Trabalhista Brasileiro

RF - Renda Fixa

RFC - Reconstruction Finance Corporation

RGPS - Regime Geral de Previdência Social

RPPS - Regime Próprio de Previdência Social dos Servidores Públicos

RV - Renda Variável

SISTEL - Fundação Sistel de Seguridade Social

SPC - Secretaria de Previdência Complementar

SPE - Sociedades de Propósito Específico

SP-PREVCOM - Fundação de Previdência Complementar do Estado de São Paulo

SUMOC - Superintendência da Moeda e do Crédito

SUSEP - Superintendência de Seguros Privados

USP - Universidade de São Paulo

VALIA - Fundação Vale do Rio Doce de Seguridade Social

VLI - Valor da Logística Integrada

WSK - Welfare State Keynesiano 
"If Karl Marx were alive today, he would be in the British Library devouring everything he could find on pension funds: the new fuel of global capitalism."

Mike Davis 


\section{SUMÁRIO}

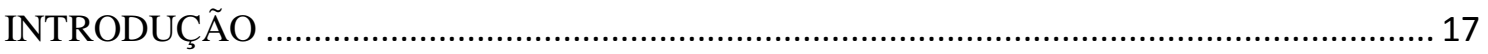

1. AS GRANDES TRANSFORMAÇÕES DO SÉCULO XX ……................................ 25

1.1 Financeirização: a crise do Estado keynesiano ………....................................... 29

1.1.1 Os ciclos de acumulação capitalista ..................................................................... 30

1.1.2 A etapa financeira do ciclo de acumulação americano ....................................... 33

1.1.3 Características e consequências da financeirização ............................................. 38

1.1.4 Financeirização e sistemas de previdência ........................................................... 45

1.2 O caso brasileiro: padrão de financiamento do ciclo desenvolvimentista ...........51

1.2.1 1930-64: Restrições ao financiamento …………............................................ 54

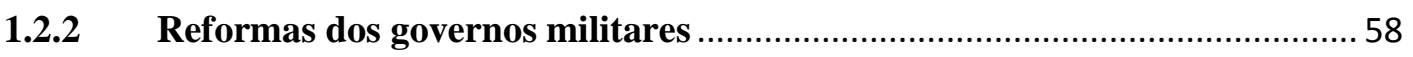

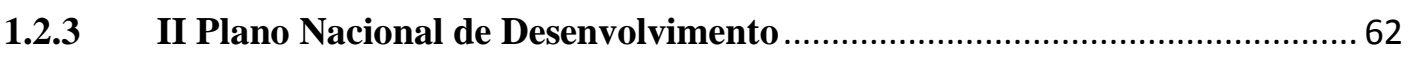

1.2.4 A década de 1980 e a crise da dívida ...........................................................67 67

\section{REGULAÇÃO DAS ENTIDADES FECHADAS DE PREVIDÊNCIA}

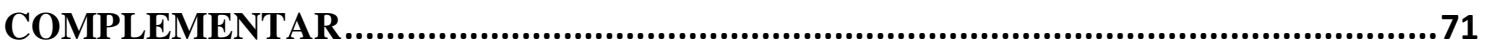

2.1 Atuação do Estado no domínio econômico ........................................................................... 73

2.1.1 A Ordem Econômica na Constituição de 1988 ............................................................ 74

2.1.2 Direito Econômico: desenvolvimento histórico e conceito........................................... 76

2.1.3 Formas de atuação do Estado no domínio econômico ................................................. 82

2.2 Antecedentes da Regulação da Previdência ....................................................................... 86

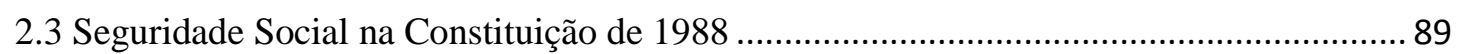

2.3.1 Previdência Social na Constituição de 1988 ............................................................... 93

2.3.2 Previdência Complementar na Constituição de 1998 ................................................ 95

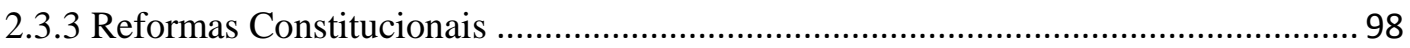

2.4 Regulação da Previdência Complementar - LC n ${ }^{\circ}$ 109/2001 ........................................... 103

2.4.1 Fundamentos e objetivos da regulação................................................................... 104

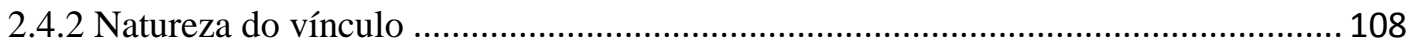

2.4.3 Forma das Entidades de Previdência Complementar ................................................ 109

2.4.4 Governança das Entidades de Previdência Complementar ...................................... 111

2.4.5 Proteção da higidez da Previdência Complementar ................................................. 113

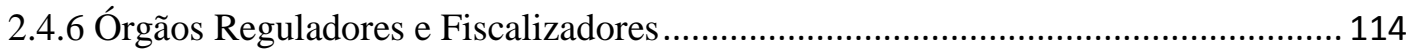

2.5 Estrutura das EFPC patrocinadas por empresas estatais ................................................. 116

2.6 Diretrizes para as aplicações: Resolução CMN n 3.792/2009 …….............................. 119 
2.7 Conclusões preliminares

3. A ATUAÇÃO DOS FUNDOS DE PENSÃO DAS EMPRESAS ESTATAIS 128

3.1. O Estado investidor e as EFPCs ......................................................................... 129

3.1.1 Os fundos públicos .......................................................................... 133

3.1.2 Os bancos públicos ............................................................................ 136

3.1.3 As EFPCs patrocinadas por estatais ........................................................ 138

3.2 Carteira de Investimentos das EFPCs ................................................................ 147

3.3 Participação das EFPCs em empresas e empreendimentos ....................................... 154

3.4 Dirigentes das EFPCs ............................................................................. 161

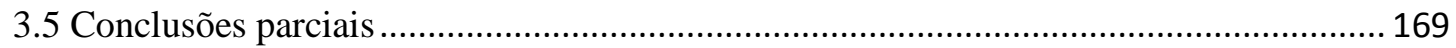

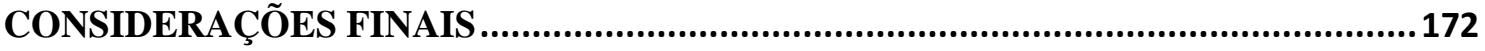

REFERÊNCIAS BIBLIOGRÁFICAS ............................................................. 179 


\section{INTRODUÇÃO}

Entre novembro e dezembro de 2014, situação e oposição travaram um debate no plenário do Congresso Nacional que se prolongou por algumas madrugadas, com discursos inflamados de parte a parte, dedos em riste e ameaças de confronto físico. $\mathrm{O}$ motivo da divergência era a mudança proposta pelo Governo Federal $^{1}$ na Lei de Diretrizes Orçamentárias daquele ano, que retiraria do cálculo do superávit primário ${ }^{2}$, os gastos estatais com obras do Programa de Aceleração do Crescimento (PAC), e com as desonerações concedidas sobre a folha de pagamento de alguns setores da economia.

Com um crescimento do Produto Interno Bruto (PIB) e consequentemente das receitas muito abaixo do esperado, a União passou longe de alcançar a meta que havia previsto para si mesmo no início do ano. Em sua defesa, o governo argumentava que os investimentos do PAC e os subsídios concedidos foram essenciais para o país, pois sem eles os níveis de emprego e renda sofreriam impactos negativos diante de um cenário econômico internacional desfavorável ao país.

Este foi um dos debates sobre a destinação dos recursos públicos mais acirrados e com maior repercussão na opinião pública dos últimos anos, sobretudo em razão da quantia considerável de recursos públicos em jogo. Dizia respeito a um montante de 167,4 bilhões de reais - economia que União, Estados e Municípios deveriam ter realizado em conjunto; ou 116,1 bilhões de reais, se considerada apenas a meta de economia do governo central (Tesouro Nacional, Banco Central do Brasil e Previdência) em 2014.

O episódio narrado impressiona e dá a dimensão da importância, em termos quantitativos, do objeto deste trabalho, pois este último valor citado equivale a aproximadamente $16,5 \%$ do total de ativos dos fundos de pensão brasileiros, ou $27,1 \%$ dos investimentos dos fundos de pensão patrocinados por órgãos e entidades da Administração Pública.

\section{Apresentação do Problema}

Um conjunto de transformações processadas nas últimas décadas converge para o relevo que ganharam os fundos de pensão. Estas transformações aconteceram principalmente em três dimensões. A primeira dimensão de transformações, que acaba por condicionar

\footnotetext{
${ }^{1}$ Projeto de Lei do Congresso Nacional - PLN nº36/2014.

2 Diferença entre despesas e receitas do setor público, excetuadas as despesas financeiras, isto é, o pagamento de juros da dívida pública.
} 
as outras duas, são as mudanças no padrão de acumulação do modo de produção capitalista. A partir da década de 1970, o capitalismo mundial entrou em uma fase de acumulação predominantemente financeira ${ }^{3}$, na qual os haveres financeiros (títulos da dívida pública, títulos privados, ações, dentre outros) passaram a prevalecer como a principal forma de riqueza, ocupando o centro das relações políticas, econômicas e sociais. Esta forma específica de valor, o capital portador de juros, busca "fazer dinheiro" sem sair da esfera financeira, sob a forma de juros de empréstimos, dividendos e outros pagamentos nascidos de sua posse. ${ }^{4}$

A expansão das finanças na última quadra do século $\mathrm{XX}$ faz parte de um processo cíclico na história do capitalismo, como mostra Giovanni Arrighi ${ }^{5}$, e começa a se formar com a criação do mercado de eurodólares em Londres e se acentua com o choque do petróleo na década de 1970, a queda do regime cambial criado em Bretton Woods, e, posteriormente com a liberalização do mercado da dívida pública dos países subdesenvolvidos. ${ }^{6}$ Como características desta fase do capitalismo encontram-se a desregulamentação e a mundialização das finanças, a elevação do fluxo de capitais, e as crescentes inovações dos instrumentos financeiros.

Outra característica, fundamental para a presente dissertação, é o crescimento da importância na economia dos chamados investidores institucionais, que atuam por meio da centralização da poupança pulverizada, sejam lucros não-reinvestidos das empresas ou renda economizada pelas famílias. Dentre os investidores institucionais encontram-se as companhias de seguro, os fundos de investimento e os fundos de pensão, como os estudados neste trabalho. Estas instituições tornaram-se, nesta fase do capitalismo, grandes detentoras das ações de companhias abertas e de títulos da dívida privada e pública em todo o mundo.

A segunda dimensão de transformações diz respeito às mudanças no papel do Estado e dos instrumentos de que dispõe para atuar na economia, em especial no caso brasileiro. As dívidas públicas, tanto dos países do centro quanto da periferia e semi-periferia do capitalismo, jogaram papel importante do processo de financeirização, em especial a partir de meados da década de 1970. Elas foram consideradas a "espinha dorsal" dos

\footnotetext{
${ }^{3}$ ARRIGHI, Giovanni. O Longo Século XX: Dinheiro, Poder e as Origens do Nosso Tempo. São Paulo: Unesp, 1996.

${ }^{4}$ CHESNAIS, François (Org.). A finança mundializada. São Paulo: Boitempo, 2005, p. 35.

5 ARRIGHI, op. cit..

${ }^{6}$ CHESNAIS, op. cit., pp. 36-44.
} 
mercados de obrigações internacionais, propiciando a sua expansão e sua estruturação nos países onde eram incipientes ou inexistentes. ${ }^{7}$ Este fato, combinado com o choque dos juros de 1979 e a valorização do dólar provocaram crescentes pressões fiscais sobre os Estados nacionais.

O Estado brasileiro, neste contexto, passou por uma forte crise fiscal que comprometeu a sua capacidade de investimento e fez secar as fontes de financiamento para o país. De maneira que o modelo de desenvolvimento lastreado no endividamento externo, que vigorou durante cerca de 50 anos no século $\mathrm{XX}$, se tornava insustentável naquele momento. Assim, o Estado Brasileiro viu comprometida a sua capacidade de atuação e de direção no domínio econômico, pelo menos pela via daqueles instrumentos tradicionalmente usados para tanto, quais sejam: o orçamento público - que passa a sofrer os constrangimentos do serviço da dívida e as pressões por austeridade típicas do período de predomínio da esfera financeira; e a atividade de bancos e empresas estatais - muitos deles vendidos ao longo da década de 1990.

A terceira dimensão de transformações refere-se às mudanças nos sistemas previdenciários a partir do último quartel do século XX. Com a fragilização fiscal dos Estados nacionais, foram colocados em xeque alguns dos instrumentos do chamado Estado de Bem Estar Social erigido no pós-guerra. Dentre estes instrumentos, destaca-se o modelo de previdência pública de repartição, no qual Estado, empregadores e trabalhadores contribuem para o pagamento de benefícios àqueles que, por algum motivo (velhice, doença, invalidez, desemprego, morte), não conseguem vender a sua força de trabalho. Outro fato que contribuiu para o questionamento da previdência pública foi o progressivo envelhecimento da população, que gerou um aumento grande no passivo das despesas sem a correspondente contrapartida na arrecadação, provocando a necessidade de maiores aportes advindos do orçamento dos Estados nacionais.

Assim, por todo o mundo foram operadas reformas que limitaram o escopo da previdência pública ou mesmo a eliminaram (como é o caso do Chile). Com isso, a previdência privada (previdência aberta ou fundos de pensão) se fortalece, seja em substituição seja em complementação à previdência pública. Isto também ocorre no Brasil, com as reformas constitucionais de 1998 e 2003 que, em linhas gerais,

\footnotetext{
${ }^{7}$ CHESNAIS, François (Org.). A finança mundializada. São Paulo: Boitempo, 2005, pp. 41-42.
} 
impuseram regras mais rígidas para o cálculo e o acesso aos benefícios da previdência social para trabalhadores da iniciativa privada e servidores públicos.

Como uma de suas principais características, a previdência privada possui a especificidade de atuar sob o regime de capitalização, utilizando o mercado da dívida pública, o mercado de ações, e também o imobiliário para valorização dos recursos arrecadados dos seus associados. Assim, a fase de expansão financeira do capitalismo parece ter como correlato o modelo de previdência privada por capitalização. Não à toa, Catherine Sauviat ${ }^{8}$ os apresenta como os principais atores dos mercados financeiros.

No Brasil, a previdência privada - chamada de Previdência Complementar pela atual legislação - tem previsão no art. 202 da Constituição Federal e é regida pela Lei

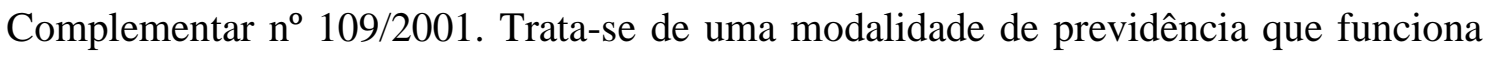
em paralelo e de forma complementar à previdência pública, gerida pelo poder público por meio do Instituto Nacional de Seguridade Social (INSS) e pelos órgãos que operam os Regimes Próprios dos Servidores Públicos (RPPS) nos Estados e Municípios.

Por sua vez, a Previdência Complementar divide-se em Aberta e Fechada. As Entidades Abertas de Previdência Complementar Aberta (EAPC) oferecem planos de previdência diversificados ao público em geral, enquanto as Entidades Fechadas de Previdência Complementar (EFPC), nomenclatura técnica dos fundos de pensão, são instituições privadas sem fins lucrativos que arrecadam recursos dos patrocinadores ou instituidores (empregadores ou instituições de classe) e participantes (empregados ou associados à respectiva entidade classista) com o objetivo de oferecer benefícios quando da aposentadoria dos trabalhadores. São entidades "fechadas" porque só podem aderir a elas as pessoas vinculadas às instituições participantes, ao contrário das entidades abertas, cujos planos de benefícios são acessíveis a todos. Ou seja, do fundo de pensão patrocinado pelo Banco do Brasil só podem participar os seus empregados, ao contrário das opções de previdência aberta oferecidas por aquele banco.

Destacam-se dentre os fundos de pensão brasileiros, pelo volume de recursos e número de participantes, três grandes entidades patrocinadas por empresas estatais: os fundos de pensão do Banco do Brasil, da Caixa Econômica Federal e da Petrobrás. Aplicam-se a

\footnotetext{
${ }^{8}$ SAUVIAT, Catherine. Os fundos de pensão e os fundos mútuos: principais atores da finança mundializada e do novo poder acionário. In: CHESNAIS, François (Org.). A finança mundializada. São Paulo: Boitempo, 2005, p. 109.
} 
estas entidades, além da LC nº109/2001, citada acima, as disposições da Lei Complementar $n^{\circ}$ 108/2001, que estabelece regras para a governança e gestão dos fundos de pensão patrocinados por entidades da Administração Pública. Esta lei prevê participação paritária nos órgãos de direção de representantes indicados pelas empresas e pelos participantes e assistidos do fundo, cabendo o voto de minerva no Conselho Deliberativo ao presidente indicado pela empresa patrocinadora. Como estamos falando de empresas cujo acionista majoritário e controlador é o Governo Federal, é lícito supor que haja forte influência do governo central na administração e gestão dos recursos das EFPCs patrocinadas pelas estatais.

\section{Hipótese de Pesquisa}

A breve explanação que fizemos até agora nos permite pontuar alguns postulados, que serão aprofundados durante a nossa investigação:

a) Nas últimas décadas, o processo de acumulação capitalista concentrou-se na esfera financeira;

b) Nas últimas décadas, houve uma crise fiscal dos Estados nacionais em geral e do brasileiro em particular, com a consequente perda de capacidade de atuação e financiamento da economia, pelo menos por meio dos instrumentos tradicionais;

c) Os sistemas de previdência social acompanharam as transformações apontadas nos dois itens anteriores, com a progressiva substituição dos regimes públicos de repartição pelos regimes de capitalização;

d) Enquanto poderosos instrumentos arrecadadores de poupança, os fundos de pensão se transformam em agentes econômicos relevantes em todo o mundo, inclusive no Brasil;

e) A estrutura jurídica dos fundos de pensão das estatais brasileiras permite que sobre eles seja exercida uma considerável influência do Poder Executivo Federal.

Com base nestes postulados podemos formular a pergunta e a hipótese que nortearão o nosso trabalho: num estágio de desenvolvimento do capitalismo em que a acumulação de capital volta a se concentrar na esfera financeira, e o Estado perde parte da sua capacidade de atuação na economia, seriam os fundos de pensão das empresas estatais uma alternativa para o financiamento do desenvolvimento? 
Nossa hipótese é de que a resposta a esta pergunta é afirmativa, dado o arranjo jurídico que possibilita ao Estado o controle destas entidades e a enorme capacidade que possuem para arrecadar poupança individual, dando origem a grandes montantes de recursos.

\section{Objeto da Pesquisa}

Esta dissertação de mestrado tem como objeto de investigação as três maiores EFPC brasileiras, quais sejam, a Caixa de Previdência dos Funcionários do Banco do Brasil (PREVI), a Fundação Petrobrás de Seguridade Social (PETROS), e a Fundação dos Economiários Federais (FUNCEF). É por meio da investigação destas três grandes entidades que buscaremos responder à hipótese formulada sobre os fundos de pensão patrocinados por estatais, e a atuação do Estado na economia.

O recorte se justifica pelo fato de serem entidades patrocinadas por empresas estatais, controladas pela União, o que confere ao poder público federal participação importante na gestão dos seus ativos, e principalmente pelo fato destes três fundos juntos deterem a maioria absoluta dos recursos das EFPC brasileiras (44,81\%) e das EFPC patrocinadas por órgãos ou entidades da Administração Pública (73,71\%). Assim reunidos, estes fundos configuram um universo capaz de oferecer as respostas buscadas por esta dissertação.

\section{Estrutura do Trabalho}

No primeiro capítulo desta dissertação pretendemos realizar uma reconstrução das transformações no capitalismo e no Estado brasileiro às quais aludimos na introdução, com enfoque para a expansão financeira do modo de produção capitalista e o padrão de desenvolvimento brasileiro que tem sua crise na década de 1980. Para isso, procederemos a uma leitura e sistematização da bibliografia existente sobre: i) fundamentos do Estado keynesiano; ii) financeirização e crise do Estado keynesiano; iii) formas de financiamento do Estado desenvolvimentista brasileiro; iv) formas e regimes da previdência social no Estado keynesiano, e após sua crise.

Não temos a pretensão de esgotar estes temas, demasiado abrangentes, nesta dissertação, mas antes mapear e situar o debate, em especial nas suas intersecções com o tema dos fundos de pensão, para prosseguirmos com as etapas posteriores da pesquisa. Aqui, tomaremos informações e referências de diferentes fontes, com a contribuição 
decisiva da economia política, mas também da história econômica e do direito econômico e financeiro.

No segundo capítulo da investigação, procederemos a uma análise mais meticulosa da legislação que regula os fundos de pensão brasileiros, deste a Constituição Federal e suas reformas à resolução do Conselho Monetário Nacional que regula os limites para os investimentos das Entidades Fechadas de Previdência Complementar, passando pelas Leis Complementares n ${ }^{\circ} 108$ e 109. Veremos também quais são as formas estudadas pelo direito econômico de atuação do Estado na economia. Com isso, queremos observar de que forma a legislação impacta e condiciona a aventada atuação estatal por meio dos fundos de pensão.

Neste estágio da pesquisa, temos o desafio de conseguir fugir da análise puramente dogmática das normas e penetrarmos no seu conteúdo político e econômico. Para isso, será de fundamental importância o entendimento do direito econômico enquanto ramo do direito destinado a instrumentalizar a política econômica do Estado, e também como método que encerra uma interpretação teleológica, funcional, um ângulo novo sob o qual podem ser estudados os fenômenos econômicos e políticos. ${ }^{9}$

O terceiro capítulo será reservado a um estudo descritivo sobre a destinação dos investimentos dos fundos de pensão aqui estudados (Previ, Petros, Funcef), de modo a verificar a concentração da carteira por tipo de ativos e quais as empresas e projetos que são participados por estas três EFPC. Esta verificação será realizada a partir de dados oficiais e públicos disponibilizados pelos órgãos reguladores, pelos próprios fundos de pensão e por relatórios de companhias participadas.

Também buscaremos traçar um perfil dos dirigentes destas três entidades, a partir de uma investigação sobre os seus presidentes. Como recorte temporal para esta parte da pesquisa (tanto para a análise dos investimentos quanto para o perfil dos gestores), estabelecemos a aprovação da nova legislação dos fundos de pensão, no ano de 2001, que conferiu a atual estruturação do setor. Verificaremos, ainda, como se inserem os fundos num contexto de novas formas de atuação do Estado e sua articulação com instrumentos públicos, como o BNDES e outros fundos administrados pelo Estado, bem como a sua interação com os atores e privados. Os resultados encontrados serão

\footnotetext{
${ }^{9}$ GRAU, Eros Roberto, A Ordem Econômica na Constituição de 1988 (Interpretação e Crítica), 12 a ed., São Paulo: Malheiros, 2007, pp. 152-155.
} 
analisados a partir dos subsídios oferecidos pela pesquisa teórica e pelo exame da legislação pertinente, o que nos permitirá verificar de que forma se dá a atuação dos fundos e qual o papel que exercem na atualidade.

Nas Considerações Finais, serão retomados os principais argumentos até então desenvolvidos e os resultados encontrados na pesquisa, de modo a relacioná-los entre si, e a partir deles aferir conclusões. Por fim, apontaremos elementos para uma agenda de pesquisa, em aberto, sobre os fundos de pensão patrocinados por órgãos e entidades da Administração Pública. 


\section{AS GRANDES TRANSFORMAÇÕES DO SÉCULO XX}

Este capítulo tem como objetivo entender, sob a perspectiva da economia política e da história econômica, as transformações sofridas pelo capitalismo mundial nas últimas décadas do século XX, com o crescimento da acumulação na esfera financeira e seus impactos nos regimes de previdência e no modelo de desenvolvimento adotado pelo Brasil. Veremos que o fenômeno descrito como financeirização fez com que ganhassem espaço os regimes de previdência privados e por capitalização, em detrimento dos modelos públicos que funcionam no sistema de repartição. No Brasil, as últimas décadas do século XX levaram ao colapso de um modelo de desenvolvimento financiado principalmente pelo endividamento externo.

A partir das lutas sociais, das experiências de guerra e da emergência de uma literatura que contestava o liberalismo econômico, ainda que dentro dos marcos do capitalismo, o século XX assiste à emergência de novas formas de relacionamento entre o Estado e a economia.

Karl Polanyi ${ }^{10}$ identifica, na transição entre os séculos XIX e XX um movimento de autoproteção da sociedade contra o que ele chama de moinho satânico do mercado autorregulável. Para o autor, o século XIX assistiu a uma novidade histórica ${ }^{11}$, a economia de mercado, um padrão institucional dirigido pelos preços e pelo lucro, não sofrendo interferência de fatores externos. ${ }^{12}$ Esta forma de organização econômica foi destruída pelas medidas protetivas que a sociedade passava a adotar, em reação à tentativa do mercado de se autorregular, para não ser aniquilada. ${ }^{13}$

O movimento de autoproteção da sociedade manifesta-se através das ações dos bancos centrais, que buscavam proteger a moeda da imposição de tarifas aduaneiras, também através da proteção social e da democratização do estado político. Importantes atores

\footnotetext{
${ }^{10}$ POLANYI, Karl. A Grande Transformação: as origens da nossa época. Rio de Janeiro: Elsevier, 2000.

${ }^{11}$ Ibidem, p. 56.

${ }^{12}$ Para José Luís Fiori, Polanyi tem o mérito de recuar no tempo histórico para encontrar as raízes últimas da crise na mercantilização do trabalho, da terra e do dinheiro, e no conflito entre as tendências expansivas dos mercados autorregulados e as medidas políticas defensivas, de resistência e contenção, tomadas pelas sociedades. Ver: FIORI, José Luís. Estados, moedas e desenvolvimento. In FIORI, José Luís (org.). Estados e moedas no desenvolvimento das nações. $2^{\text {a }}$ Ed. Petrópolis: Editora Vozes, 1999.

${ }^{13}$ POLANYI, op. cit., pp. $172-174$ e p. 289.
} 
deste processo foram as organizações sindicais e políticas dos trabalhadores na Europa, influenciadas pelas ideias socialistas e pela Revolução Russa. ${ }^{14}$

A primeira grande guerra (1914-18) também contribui para estas transformações. A economia de guerra leva a uma expansão das atividades do Estado no campo econômico, especialmente no que diz respeito à centralização econômica e ao planejamento. ${ }^{15}$ Já na segunda grande guerra (1939-45), o Estado lança mão de novos processos de captação da poupança popular, do empréstimo compulsório à emissão sistemática de títulos da dívida pública. ${ }^{16}$

Para Polanyi, ainda há uma tentativa, após a primeira guerra, de se restaurar os elementos moldados pelo mercado autorregulável, como o padrão-ouro, o Estado liberal e o equilíbrio de poder entre as nações europeias. Entretanto, na década seguinte há um colapso do sistema econômico internacional que torna insustentável a manutenção destes elementos. ${ }^{17}$ A grande depressão cria condições para que a doutrina econômica liberal fosse abandonada. Vejamos o exemplo do financiamento da economia estadunidense:

Diante da contração abrupta de mais de $30 \%$ no nível de atividade nos Estados Unidos da América, o governo de Herbert C. Hoover anteriormente, portanto, ao New Deal de Franklin D. Roosevelt criou instituições financeiras públicas com o objetivo explícito de sustentar o investimento privado em longo prazo. Em 1932, foi criada a Reconstruction Finance Corporation (RFC), com o objetivo de realizar empréstimos para bancos, ferrovias e companhias de seguro. A partir dessa experiência, o governo americano foi estendendo sua atuação financeira para as áreas de agricultura, exportação e habitação. Casos semelhantes também vieram a ocorrer no cenário europeu. ${ }^{18}$

\footnotetext{
${ }^{14}$ POLANYI, Karl. A Grande Transformação: as origens da nossa época. Rio de Janeiro: Elsevier, 2000, pp. 254-275. Para uma leitura sobre a relação entre as transformações políticas do Estado e os programas das organizações marxistas no começo do século XX, ver COUTINHO, Carlos Nelson. Contra a corrente: ensaios sobre democracia e socialismo. São Paulo: Cortez Editora, 2000, pp. 38-48.

${ }^{15}$ BERCOVICI, Gilberto. O Ainda Indispensável Direito Econômico. In BENEVIDES, Maria Victoria de Mesquita; BERCOVICI, Gilberto; MELO, Claudineu de (orgs.), Direitos Humanos, Democracia e República: Homenagem a Fábio Konder Comparato. São Paulo: Quartier Latin, 2009, pp. 503-519.

${ }^{16}$ COMPARATO, Fábio Konder. O Indispensável Direito Econômico. In Estudos e Pareceres de Direito Empresarial. Rio de Janeiro: Forense, 1978, pp. 453-472.

${ }^{17}$ POLANYI, op. cit., pp. 37-47.

${ }^{18}$ TORRES FILHO, Ernani Teixeira, e COSTA, Fernando Nogueira da. Financiamento de Longo Prazo no Brasil: um mercado em transformação. Revista Economia e Sociedade, 2012, p. 6.
} 
A grande depressão que atinge a Europa na década de 30 dá forças aos movimentos e correntes acadêmicas que questionavam o liberalismo econômico. Aqui, destaca-se a formulação teórica de John Maynard Keynes. ${ }^{19}$ Keynes inverte a causalidade entre poupança e investimento pregada na abordagem ortodoxa. $\mathrm{O}$ autor argumenta que a magnitude da poupança efetiva é necessariamente determinada pela escala do investimento, e que esta escala é promovida por uma taxa de juro baixa. Por sua vez, os níveis de emprego e renda da economia dependem dos gastos autônomos em investimento.

A partir deste postulado, Keynes produz um prognóstico clássico e poderoso da economia política, o de que o Estado deve controlar determinadas áreas da vida econômica, através de uma extensão das funções do governo. Esta seria a forma de assegurar o pleno emprego, aumentar e suplementar o estímulo ao investimento e atingir uma distribuição mais equitativa da riqueza e dos rendimentos. ${ }^{20}$ As suas proposições levaram ao que se convencionou chamar de revolução keynesiana, dando fundamento teórico à atuação do Estado no domínio econômico, com o objetivo de reduzir a intensidade e duração das crises cíclicas do capitalismo. ${ }^{21}$

Para Avelãs Nunes ${ }^{22}$, a revolução keynesiana fundamentou a emergência de um "Estado-providência", pois Keynes percebeu que, para evitar grandes sobressaltos como o da grande depressão, seria necessária a manutenção do poder de compra dos trabalhadores, mesmo aqueles sem emprego. Para Keynes, a desigualdade acentuada de rendimentos contraria mais do que favorece o desenvolvimento da riqueza. Esta outra proposição keynesiana constituiu fundamento teórico para a intervenção do Estado na regulamentação das relações sociais, no reconhecimento de direitos econômicos e sociais aos trabalhadores e na implantação de sistemas públicos de segurança social. Através destes instrumentos, buscou-se uma equação capaz de conciliar progresso social e eficácia econômica, dentro do modo de produção capitalista.

\footnotetext{
${ }^{19}$ KEYNES, John Maynard. Teoria Geral do Emprego, do Juro e da Moeda. Lisboa: Relógio D’Água Editores, 2010.

${ }^{20}$ Ibidem, pp. 355-364.

${ }^{21}$ NUNES, António José Avelãs. Uma Introdução à Economia Política. São Paulo: Quartier Letin, 2007, p. 590.

${ }^{22}$ Ibidem, pp. 585-590.
} 
Para Claus Offe ${ }^{23}$, o Welfare State Keynesiano (WSK) foi um arranjo específico de organização econômica que contribuiu para compatibilizar a democracia de massas e o capitalismo na Europa durante boa parte do século XX. O WSK foi adotado enquanto concepção básica do Estado e da prática estatal em quase todos os países ocidentais, como um mecanismo eficiente para dirigir e controlar os conflitos socioeconômicos. Para o autor, o WSK proporcionou um boom econômico que favoreceu todas as economias capitalistas e levou o conflito de classes para um patamar mais economicista e institucionalizado, em torno do problema da distribuição do excedente econômico.

José Luís Fiori ${ }^{24}$ aponta que, com o pensamento de Keynes, foram abertos caminhos para a presença de um Estado ativo e intervencionista, que viabilizou o mais longo e contínuo processo de crescimento experimentado pelas economias capitalistas. Fiori também atenta para a composição de classes que tornou possível este período de bem estar econômico e social:

As políticas de corte keynesiano, atuando de forma indireta sobre a demanda, redinamizaram as economias e diminuíram, durante trinta anos, o impacto cíclico das crises, permitindo o pleno emprego e desativando a ideia socialista de controle direto e detalhado da produção. Mais do que isso, criaram as premissas de um pacto explícito ou implícito entre sindicatos e capitalistas, que fundou as bases do Welfare State e de uma paz social que duraria até os anos $70 .^{25}$

Francisco de Oliveira ${ }^{26}$, por sua vez, identifica que nesse período surge o modo social democrata de produção. O modo social democrata de produção tem como característica principal a forte presença do fundo público como padrão de financiamento da economia capitalista. ${ }^{27} \mathrm{O}$ fundo público, em suas diversas formas, passou a ser o pressuposto do financiamento da acumulação de capital e do financiamento da reprodução da força de

\footnotetext{
${ }^{23}$ Outro fator de estabilização que possibilitou a convivência da democracia de massas e o capitalismo foi a democracia partidária competitiva, que implicou uma mudança de conteúdo dos programas partidários, com a sua desradicalização, burocratização da sua direção e uma crescente heterogeneidade estrutural e cultural dos seus filiados. Ver OFFE, Claus. A Democracia Partidária Competitiva e o "Welfare State" Keynesiano: fatores de estabilidade e desorganização. In OFFE, Claus. Problemas Estruturais do Estado Capitalista. Rio de Janeiro: Tempo Brasileiro, 1984, pp. 356-385.

${ }^{24}$ FIORI, José Luís. Para repensar o papel do Estado sem ser um neoliberal. In Revista de Economia Política, vol. 12, nº 1, janeiro/março de 1992, pp. 76-89.

${ }^{25}$ Ibidem, pp. 76-77.

${ }^{26}$ OLIVEIRA, Francisco de. Os direitos do antivalor: a economia política da hegemonia imperfeita. Editora Vozes. Petrópolis, 1998, p. 58.

${ }^{27}$ Ibidem, p. 19.
} 
trabalho. Ele vincula-se a finalidades determinadas aprioristicamente ${ }^{28}$, e é concebido como instrumento econômico anticíclico. Durante o período do WSK, o financiamento público torna-se abrangente, estável e marcado por regras assentadas pelos principais grupos sociais e políticos. Criam-se, então, uma esfera pública e um mercado institucionalmente regulado.

No que diz respeito ao financiamento da acumulação de capital, são exemplos os subsídios para a produção, a constituição de setores estatais produtivos, os incentivos para ciência e tecnologia, além do sustento do mercado financeiro e de capitais através de bancos e/ou fundos estatais. Já do lado do financiamento da reprodução da força de trabalho estão a constituição de sistemas de saúde e educação universais, a previdência social, o seguro-desemprego, os subsídios para o transporte, benefícios familiares ${ }^{29}$.

Em convergência com os autores citados anteriormente, Leda Paulani ${ }^{30}$ demonstra que o Estado de Bem Estar Social, erigiu a sua própria forma de lidar com a sobrevivência material e com a incapacidade - passageira ou permanente - de os indivíduos venderem a sua força de trabalho. Esta forma própria é um sistema de proteção público, universal e de amplo alcance, baseado nos seguintes princípios: i) solidariedade intergeracional; ii) financiamento público de parte dos benefícios, e; iii) vínculo não tão rígido entre acesso ao benefício e contribuição ao sistema. A autora nota que o termo seguridade social, que dá nome a este sistema público de proteção, nasce com o Social Security Act, do presidente estadunidense Franklin D. Roosevelt, sem dúvida um dos marcos do que se chamou de revolução keynesiana na condução do Estado e da economia.

\subsection{Financeirização: a crise do Estado keynesiano}

No período descrito acima, o capitalismo viveu uma acumulação predominantemente na esfera produtiva, o que contribuiu para sustentar o WSK. Em sentido oposto, as últimas três décadas do século XX assistiram a uma acumulação de capital predominantemente na esfera financeira, retirando a centralidade do trabalho e da produção para a criação de valor. Passa a predominar o que Marx denomina de capital fictício. Veremos abaixo

\footnotetext{
${ }^{28}$ OLIVEIRA, Francisco. Os direitos do antivalor: a economia política da hegemonia imperfeita. Editora Vozes. Petrópolis, 1998, p. 31.

${ }^{29}$ Ibidem, p. 21.

${ }^{30}$ PAULANI, Leda Maria. Seguridade social, regimes previdenciários e padrão de acumulação: uma nota teórica e uma reflexão sobre o Brasil. In FAGNANI, Eduardo; HENRIQUE, Wilnês; e LÚCIO, Clemente Ganz (orgs.). Previdência Social: Como incluir os excluídos. LTr: São Paulo, 2008.
} 
como se deu a configuração desta etapa do capitalismo, bem como suas implicações sobre as instituições do WSK.

\subsubsection{Os ciclos de acumulação capitalista}

Ao fazer uma análise do desenvolvimento histórico do capitalismo, Arrighi identifica semelhanças nos quatro ciclos sistêmicos de acumulação (genovês, holandês, inglês e americano) por ele estudados, os "longos séculos". Estes ciclos de acumulação compõem a ascensão, plena expansão e superação dos agentes e estruturas hegemônicas no período. Em cada um dos ciclos, há uma concentração da expansão capitalista ora na esfera financeira ora na esfera material, e são observados alguns momentos críticos nos quais são criadas as condições para, primeiramente, o nascimento de um novo ciclo de acumulação e, depois, para a superação do ciclo anterior pelo nascente. Esses momentos críticos serão chamados de crise sinalizadora e crise terminal, respectivamente.

Para Arrighi, os "longos séculos" ficam cada vez mais curtos. Isso decorre, para o autor, do avanço cada vez maior dos estágios do desenvolvimento capitalista. À medida que nos distanciamos dos estágios mais iniciais desse desenvolvimento, leva cada vez menos tempo para que eles se desenvolvam por completo, gerem as suas contradições e sejam superados.

Assim sendo, o longo século genovês aparece como o mais extenso, tendo durado 290 anos, enquanto o longo século britânico durou 190 anos. Outra forma de medição, esta menos arbitrária para Arrighi, é a distância entre as crises sinalizadoras de cada ciclo. Este tempo também diminui progressivamente, sendo de 220 anos a distância entre a crise sinalizadora do regime genovês e a do regime holandês, 180 anos entre a do holandês e a do ciclo britânico, e, por fỉm, 130 anos entre a crise sinalizadora britânica e a americana.

Assim, os ciclos sistêmicos de acumulação se superpõem, sendo o novo ciclo engendrado no âmbito da crise sinalizadora do ciclo anterior, que é completamente superado através da sua crise terminal. Ao período que vai da crise sinalizadora do ciclo sistêmico anterior à crise terminal do novo ciclo, Arrighi dá o nome de longo século, identificando em cada um deles três momentos distintos.

O primeiro período vai da crise sinalizadora do regime anterior à sua crise terminal. Durante este intervalo, desenvolve-se, durante o período de expansão financeira (MD') 
do ciclo anterior, um novo regime de acumulação. Este novo regime é gestado exatamente a partir das contradições internas que surgem no ciclo sistêmico anterior. Como exemplo, o ciclo americano começa a se desenvolver a partir da crise sinalizadora do período inglês, marcada, para Arrighi, com o início da grande depressão, no ano de 1873.

O segundo período dos "longos séculos" é aquele no qual vai se dar a consolidação e o desenvolvimento do novo regime de acumulação, através de uma expansão predominantemente material (DM). Aqui, os agentes da região dominante controlam e se beneficiam de toda a expansão econômica mundial. O período de expansão material começa com a crise terminal do regime anterior e termina na crise sinalizadora do novo ciclo.

Esta etapa da acumulação encontra seus limites na tendência à queda na taxa de lucro. ${ }^{31}$ Num dado momento, constitui-se um excedente de capitais ou o capital aplicado excede o nível de investimento que impediria a queda na taxa de lucros. Os centros comerciais, diante disso, tendem a tentar diminuir barreiras geográficas ou de fechamento de mercados nacionais. Entretanto, ao fazerem isso, acirram a concorrência e minam as instituições deste ciclo. Sobre esta tendência, escreveu Arrighi:

(...) toda expansão material da economia mundial capitalista baseou-se numa estrutura organizacional específica, cuja vitalidade foi progressivamente minada pela própria expansão. (...) Mais especificamente, à medida que aumentou a massa de capital que buscava reinvestimento no comércio, sob o impacto dos lucros ascendentes ou elevados, uma parcela crescente do espaço econômico necessário para mantê-los em ascensão ou elevados foi sendo consumida (...). Quando os centros de acumulação tentaram opor-se aos lucros decrescentes, através da diversificação de seus negócios, eles também aniquilaram a distância geográfica e funcional que os vinha mantendo fora do caminho uns dos outros, em mercados mais

\footnotetext{
${ }^{31}$ A queda tendencial da taxa de lucro foi esboçada por Adam Smith para expansões comerciais dentro de uma mesma jurisdição política. Entretanto, para Arrighi, a tese pode ser transposta para um sistema de acumulação com jurisdições múltiplas. A tendência à queda da taxa de lucros decorre do acirramento da competitividade entre os agentes econômicos, que acaba empurrando para baixo as suas margens de lucro. A mesma tendência foi observada por Marx, ao notar que o capitalismo induz, dentro desta competitividade entre os atores econômicos, a uma concentração de capital e a uma queda nos salários reais, o que dá novo fôlego à taxa de lucro e à expansão material.
} 
ou menos protegidos. Com o resultado dessa dupla tendência, a cooperação entre os centros foi substituída por uma concorrência cada vez mais violenta, que deprimiu os lucros ainda mais e acabou por destruir as estruturas organizacionais em que se baseara a expansão material anterior. $^{32}$

Assim, a fase de expansão material é representada graficamente numa curva com trajetória em "S", com fases de rendimentos crescentes e fases de rendimentos decrescentes.

Ao final deste período de expansão material e como consequência do acirramento da competição intercapitalista, acontece uma crise chamada por Arrighi de crise sinalizadora. A crise sinalizadora marca o momento em que o agente principal do processo de acumulação capitalista passa a deslocar seu capital dos setores produtivos e comercial para a esfera financeira. Essa transferência do capital para a especulação e a intermediação revela uma avaliação negativa, um pessimismo dos agentes econômicos, em relação à possibilidade de lucrar com o reinvestimento na esfera material, refletindo a queda na taxa de lucros. Assim, a crise é o "sinal" de uma crise sistêmica subjacente profunda, que a passagem do capital para a esfera das finanças vai adiar temporariamente. Com a crise sinalizadora, repete-se o primeiro período do "longo século", no qual vão sendo geradas as condições para a superação do ciclo sistêmico de acumulação.

Entretanto, como observa o autor, o objetivo primordial do capitalismo é a expansão monetária e não a expansão comercial ou produtiva em si mesma. Assim, o capitalista só reinveste o seu lucro na esfera material se houver expectativa positiva quanto ao seu retorno. Grosso modo, como há uma tendência à queda nesse retorno, conforme observamos, o capital tende a concentrar-se na esfera financeira:

Quando os rendimentos do capital investido no comercio de mercadorias, apesar de ainda positivos, caem abaixo de um índice crítico (Rx), que é o que o capital pode ganhar nos comércios monetários, um número crescente de organizações capitalistas abstémse de reinvestir os lucros na expansão adicional do comércio de

\footnotetext{
${ }^{32}$ ARRIGHI, Giovanni. O Longo Século XX: Dinheiro, Poder e as Origens do Nosso Tempo. São Paulo: Unesp, 1996, pp. 231-232.
} 
mercadorias, Todos os excedentes de caixa que elas acumulam são desviados do mercado de produtos para os mercados financeiros. ${ }^{33}$

Nas etapas de expansão financeira da economia ocorre uma coincidência aproximada entre oferta e demanda por capital monetário. Enquanto alguns agentes capitalistas deslocam seus fluxos de caixa do sistema comercial para o sistema de crédito, aumentando a oferta de empréstimos, outros agentes buscam cada vez mais recursos financeiros adicionais para sobreviverem num meio mais competitivo. Para Arrighi, característica importante da etapa de expansão financeira é a sua volatilidade ou turbulência, em contraste com a relativa estabilidade das fases de expansão na esfera material. As crises sinalizadoras indicam que checou ao fim essa estabilidade e indicam também o surgimento de uma nova via de desenvolvimento, dotada de maior potencial de crescimento, que dará origem ao ciclo de acumulação material posterior.

\subsubsection{A etapa financeira do ciclo de acumulação americano}

Após essa visão panorâmica da teoria de Arrighi sobre os ciclos sistêmicos de acumulação capitalista, iremos nos deter, neste item, ao último longo século analisado pelo autor: o longo século XX, de domínio americano, especialmente à etapa de expansão financeira deste período, que tem início na crise sinalizadora de derrocada do regime de Bretton Woods.

Cada ciclo sistêmico baseia-se numa estrutura organizacional específica, que dá suporte à acumulação capitalista. Essas estruturas atuam internalizando custos e propiciando a expansão capitalista. Enquanto no ciclo holandês as Companhias de Navegação internalizaram custos de proteção da acumulação, no ciclo britânico as máquinas da Revolução Industrial conseguiram avançar, internalizando custos de produção.

No ciclo americano, a estrutura organizacional que vai internalizar custos, viabilizando a acumulação, é a das multinacionais, grandes corporações dentro das quais há uma integração das etapas de produção no interior de uma mesma unidade produtiva e de planejamento, propiciando uma internalização dos custos de transação, com ganhos na economia de escala, além de altas margens de lucro e menor insegurança quanto aos fatores de mercado.

\footnotetext{
${ }^{33}$ ARRIGHI, Giovanni. O Longo Século XX: Dinheiro, Poder e as Origens do Nosso Tempo. São Paulo: Unesp, 1996, p. 236.
} 
Peter Evans ${ }^{34}$ também aponta as multinacionais como a materialização organizacional do capital internacional. Para o autor, as multinacionais não são simplesmente empresas capitalistas que existem para dar lucro, elas estendem a alienação através das fronteiras políticas: instalam-se nas periferias ou semiperiferias do capitalismo, mas suas decisões estratégicas são formadas no centro. As mudanças de estrutura das multinacionais levam a uma evolução organizacional das empresas americanas, com o controle de "impérios empresariais de escala". Essa organização das empresas americanas foi central para que o país vencesse a "corrida" contra o capitalismo alemão no momento da crise do ciclo inglês, a partir de 1870 .

Entretanto, para Arrighi, este não foi o único fator que levou os EUA a assumirem a condição de centro de um novo ciclo sistêmico de acumulação. A expansão norteamericana, que num primeiro momento se deu incorporando novas áreas ao seu território e, num segundo momento, expandindo a área sob sua influência, fez nascer uma economia autocentrada. Enquanto a Inglaterra era uma oficina e um entreposto comercial, os EUA se tornaram uma economia que produzia para si mesma. $\mathrm{O}$ oeste estadunidense fornecia insumos para as indústrias do leste, enquanto a América do Sul, sob influência norte-americana, era fonte de divisas do país.

Assim, com a integração vertical dos processos de produção e troca dentro das empresas, com a integração continental e a expansão no espaço transacional, faz nascer um capitalismo autocentrado, com um fortíssimo peso do Estado sustentando a acumulação, por meio de um complexo militar-industrial de dimensões continentais e sua vasta rede de governos subalternos.

Após as duas grandes guerras mundiais, consolida-se o modelo americano. Já durante a década de 1920, entretanto, a produtividade começa a aumentar nos Estados Unidos num ritmo maior do que em qualquer parte do mundo, acentuando a vantagem competitiva deste país em relação àqueles que, já naquela época, eram seus devedores. Aumenta, assim, a dependência do sistema mundial de pagamentos em relação ao dólar norte-americano.

O confronto mundial da década de 40 traduziu-se no estabelecimento de uma nova ordem mundial, centrada nos Estados Unidos e por eles organizada. Com o fim da

34 EVANS, Peter. A tríplice aliança: as multinacionais, as estatais e o capital nacional no desenvolvimento dependente brasileiro. Rio de Janeiro: Zahar, 1980, pp. 29-58. 
guerra, já estavam estabelecidos, para Arrighi, os três principais contornos do novo sistema monetário internacional. Em Hiroshima e Nagazaki foram estabelecidos os novos parâmetros no que diz respeito aos meios de violência que serviriam de base à dominação militar americana. Da mesma forma, com a Carta das Nações Unidas firmaram-se as bases para a nova organização das relações internacionais e para a legitimação da gestão do Estado e da guerra. O terceiro contorno, que diz respeito ao sistema monetário internacional, foi estabelecido através dos acordos de Bretton Woods.

Como consequência de seus sucessivos superávits comerciais, os EUA passam a desfrutar praticamente de um monopólio da liquidez mundial, com suas reservas de ouro chegando a $70 \%$ das disponíveis em todo o globo ${ }^{35}$ e uma crescente demanda por dólares. Os americanos se beneficiaram ainda da concentração e da centralização da capacidade produtiva e da demanda efetiva, o que lhes permitiu liderar a nova etapa de expansão material do capitalismo, em especial após a segunda grande guerra.

Neste contexto, é decisiva a importância dos acordos firmados em Bretton Woods ${ }^{36} \mathrm{em}$ 1944 e as instituições que deles decorreram. A regulamentação financeira revela um papel importante do Estado na gestão e controle das finanças. Arrighi aponta uma originalidade do sistema monetário gestado em Bretton Woods. Nos sistemas monetários anteriores, inclusive o britânico, os circuitos e redes de altas finanças tinham sido controlados por banqueiros e financistas privados, que os organizavam a partir das suas próprias perspectivas de lucro. Ao contrário, no sistema nascido em Bretton Woods:

(...) a "produção" do dinheiro mundial foi assumida por uma rede de organizações governamentais, primordialmente movidas por considerações de bem-estar, segurança e poder - em princípio, o FMI e o Banco Mundial e, na prática, o Sistema da Reserva Federal dos Estados Unidos, agindo em concerto com os bancos centrais dos

\footnotetext{
${ }^{35}$ ARRIGHI, Giovanni. O Longo Século XX: Dinheiro, Poder e as Origens do Nosso Tempo. São Paulo: Unesp, 1996, p. 284.

${ }^{36}$ Quarenta e quatro países, incluindo o Brasil, reuniram-se em New Hampishire (EUA) em Julho de 1944 na Conferência Monetária e Financeira das Nações Unidas com objetivo de estabelecer as regras do sistema financeiro internacional. A reunião aconteceu quando a Segunda Guerra Mundial caminhava para o seu final e o mundo sentia ainda os reflexos da Grande Depressão dos anos 1930. O acordo de Bretton Woods definiu que cada país seria obrigado a manter uma política monetária que assegurasse a taxa de câmbio de sua moeda "congelada" em relação ao dólar, dando surgimento ao padrão "dólar-ouro" na economia mundial. Também durante a conferência foram criadas as instituições financeiras multilaterais, como o Banco Mundial e o Fundo Monetário Internacional.
} 
aliados mais íntimos e mais importantes do país. Assim, o dinheiro mundial tornou-se um subproduto das atividades de gestão do Estado. $^{37}$

François Chesnais ${ }^{38}$ aponta que, após a Segunda Guerra Mundial, o capitalismo viveu décadas de acumulação sem ruptura. Mesmo os breves períodos de recessão durante o que se chamou de trinta anos gloriosos, eram períodos de ajustes e mudanças dentro do capitalismo, não tendo havido ruptura. Ainda segundo o autor, para alongar o período de acumulação sem choques os países dominantes, em especial os EUA, construíram um arranjo geoeconômico em que a exploração de mais-valor migrou para a Ásia, enquanto o epicentro do setor financeiro permaneceu na Europa e nos EUA. Como consequência, o capital resultante da reprodução ampliada, não reinvestido, voltava a estes centros financeiros. Isto estará na gênese do que Arrighi chama de crise sinalizadora do ciclo sistêmico americano.

Para Arrighi, entre 1968 e 1973 foi gerada a crise iminente do ciclo americano. Isso se deu, para o autor, em três frentes: a militar, com a derrota no Vietnã; a ideológica, com a perda de espaço da cruzada anticomunista; e a financeira, com a perda de sustentação do sistema de Bretton Woods.

Parece-nos que este terceiro aspecto foi o mais decisivo para a passagem da etapa material para a etapa financeira da economia capitalista. Isso porque o fim do regime cambial de Bretton Woods, em 1973/74, deu início a uma era de desregulamentação que levou a um domínio da esfera do capital financeiro.

A nova etapa de expansão financeira tem seu embrião na formação de um mercado offshore em Londres ${ }^{39}$, que deu origem ao que se convencionou chamar de eurodólares. A causa da formação deste mercado, que teve sua explosão a partir de 1968, foi a forte migração dos lucros não reinvestidos das multinacionais norte-americanas, para tirar proveito dos custos mais baixos e da maior liberdade de ação proporcionados por aquele

\footnotetext{
${ }^{37}$ ARRIGHI, Giovanni. O Longo Século XX: Dinheiro, Poder e as Origens do Nosso Tempo. São Paulo: Unesp, 1996, p. 285.

${ }^{38}$ CHESNAIS, François. El fin de um ciclo: Alcance y rumbo de la crisis financeira. 2008. Disponível em: 〈http://www.iade.org.ar/uploads/c87bbfe5-1033-09ca.pdf>. Acesso em: 31.07.2012, pp. 1-22; e CHESNAIS, François. (Org.). A mundialização financeira: gênese, custos e riscos. São Paulo: Xamã, 1998, pp. 11-33.

${ }^{39} \mathrm{O}$ mercado offshore londrino foi criado em 1958, com estatuto próprio, aproximando-se de um paraíso fiscal, conforme mostra CHESNAIS, François (Org.). A finança mundializada. São Paulo: Boitempo, 2005, p. 38.
} 
mercado. Esse fluxo se acelera ainda mais a partir de 1970, com o esgotamento do dinamismo da idade de ouro (os trinta anos de prosperidade do capitalismo) ${ }^{40}$. Com o tempo, o acúmulo deste capital se tornou incompatível com o padrão dólar-ouro estabelecido em Bretton Woods.

O rompimento unilateral dos americanos com o acordo que haviam liderado, em 1974, é o momento marcante de um período de forte desregulamentação e liberalização financeira. François Chesnais ${ }^{41}$, estudioso do processo de financeirização, divide este período em três fases. Durante a primeira fase, entre as décadas de 60 e 80, há uma integração indireta do capital financeiro mundial através do mercado de eurodólares, além de uma evolução do sistema financeiro rumo às finanças diretas. Na segunda fase, entre 1980 e 1985, ocorre um processo de alta brutal da taxa de juros e de securitização $^{42}$ da dívida pública. O mercado de títulos da dívida pública seria posteriormente chamado de "espinha dorsal" do mercado financeiro internacional. A associação destes fatores (juros e securitização da dívida) faz nascer a ditadura dos credores, ou, mais precisamente, do capital patrimonial rentista contemporâneo. A partir de 1985, a desregulamentação entra em sua terceira fase, com um ganho de complexidade e inovação dos produtos do mercado financeiro. ${ }^{43}$

O processo vivido nas últimas décadas do século $\mathrm{XX}$, entretanto, não é exatamente uma novidade na história do capitalismo. Nas palavras de Arrighi ${ }^{44}$ :

Expansões financeiras desse tipo repetiram-se desde o século XIV, como a reação característica do capital à intensificação das pressões competitivas que decorreram, invariavelmente, de todas as grandes expansões do comércio e produção mundiais. A escala, o âmbito e a sofisticação técnica da atual expansão financeira são, é claro, muito maiores que os das expansões anteriores. Mas essa maior escala, âmbito e sofisticação técnica nada mais são que a continuação da sólida tendência da longue durée do capitalismo histórico à formação de blocos cada vez mais poderosos de organizações governamentais e

\footnotetext{
${ }^{40}$ CHESNAIS, François (Org.). A finança mundializada. São Paulo: Boitempo, 2005, pp. 37-39.

${ }^{41}$ CHESNAIS, François. (Org.). A mundialização financeira: gênese, custos e riscos. São Paulo: Xamã, 1998, pp. 249-318.

${ }^{42}$ Securitização, neologismo derivado da língua inglesa, é a possibilidade de comercializar em mercados secundários os títulos de dívida de uma empresa ou do Estado.

${ }^{43}$ CHESNAIS, François (Org.). A finança mundializada. Op. cit. , pp. 40- 41.

${ }^{44}$ ARRIGHI, Giovanni. O Longo Século XX: Dinheiro, Poder e as Origens do Nosso Tempo. São Paulo: Unesp, 1996, p. 309.
} 
empresariais como principais agentes da acumulação do capital em escala mundial.

\subsubsection{Características e consequências da financeirização}

Realizada esta breve discussão sobre os antecedentes do atual período de acumulação, caracterizada por sua predominância na esfera financeira, passamos, então, a analisar neste subitem as características da financeirização e suas consequências para o desempenho da economia mundial, com especial atenção ao continente latinoamericano.

François Chesnais define o processo de acumulação financeira vivido nas últimas décadas do século XX como a:

(...) centralização em instituições especializadas de lucros industriais não reinvestidos e de rendas não consumidas, que têm por encargo valorizá-los sob a forma de aplicação em ativos financeiros - divisas, obrigações e ações - mantendo-os fora da produção de bens e serviços. $^{45}$

A definição apresentada, apesar de sucinta, nos fornece dois elementos essenciais para entender esta etapa da acumulação capitalista. O primeiro deles é a exterioridade do capital financeiro em relação à economia real, ou seja, a produção e circulação de mercadorias e serviços.

O segundo elemento é a presença dos investidores institucionais, isto é, instituições centralizadoras de poupança. O objeto de estudo desta dissertação, as Entidades Fechadas de Previdência Complementar (EFPC), conhecidas como fundos de pensão, são, como veremos posteriormente, um exemplo de investidor institucional, e têm um protagonismo neste processo.

O crescimento e o protagonismo assumido pelos investidores institucionais estão entre os fatores ${ }^{46}$ apontados por Chesnais como responsáveis pelo fato de o capital portador de juros encontrar-se atualmente no centro das relações econômicas e sociais. As instituições financeiras, às quais nos referimos no parágrafo anterior, especialmente as não-bancárias, centralizam os fundos não reinvestidos de empresas e famílias, sobretudo

\footnotetext{
${ }^{45}$ CHESNAIS, François (Org.). A finança mundializada. São Paulo: Boitempo, 2005, p. 37.

${ }^{46}$ Ibidem, pp. 35-36.
} 
planos de previdência privados e poupança salarial, e buscam "fazer dinheiro" sem sair da esfera financeira, sob a forma de juros de empréstimos, dividendos e outros pagamentos recebidos a título de posse de ações.

O outro fator pelo qual esse tipo específico de capital passa a ter tal centralidade é a liberação dos movimentos dos capitais e desregulamentação dos sistemas financeiros nacionais. Ainda conforme Chesnais, a desregulamentação desdobra-se em três "D" constitutivos da mundialização financeira que conformam um novo paradigma de regulação (ou a falta dela) das finanças mundiais, quais sejam ${ }^{47}$ : a desregulamentação financeira; a desincompartimentalização; e a desintermediação. A desregulamentação financeira diz respeito às reformas implementadas pelas instituições multilaterais, notadamente o FMI e o Banco Mundial com o objetivo de eliminar as barreiras à circulação do capital. A desincompartimentalização traz consigo duas dimensões, uma interna e outra externa. A dimensão interna refere-se às funções financeiras, quais sejam: câmbio, crédito, e ações que deixam de existir em departamentos ou instituições separadas dos grupos financeiros. A dimensão externa, por sua vez, está relacionada à abertura dos mercados de títulos públicos aos operadores estrangeiros e abertura da bolsa às empresas estrangeiras. Já a desintermediação diz respeito ao fato de as instituições não-bancárias passarem a ter acesso aos mercados como emprestadoras.

O capital financeiro se comporta de maneira a privilegiar operações de curto prazo, buscando formas de valorização que devem atender às necessidades de liquidez e segurança do investimento. Suas movimentações têm finalidade exclusiva de produção de mais-valia, que se traduz, neste caso, na valorização do ativo. ${ }^{48}$ Leda Paulani aponta que, com sua lógica própria, o capital fictício impõe um novo ritmo às transações econômicas. Os investimentos ficam cada vez mais voláteis, em busca de maiores taxas de lucros e de lucros mais rápidos, tornando-se independentes da esfera produtiva ${ }^{49}$.

\footnotetext{
${ }^{47}$ CHESNAIS, François (Org.). A finança mundializada. São Paulo: Boitempo, 2005, p. 46.

${ }^{48}$ CHESNAIS, François. (Org.). A mundialização financeira: gênese, custos e riscos. São Paulo: Xamã, 1998, pp. 258-259.

49 Leda Paulani explica que, com a figura do crédito, o processo de acumulação se autonomiza da produção e da realização da mais valia. Apesar de o crédito acelerar o desenvolvimento das forças produtivas, ele abre as portas para a especulação e as crises, com a entrada em cena do capital portador de juros. Ver: PAULANI, Leda M. A Autonomização das formas verdadeiramente sociais na teoria de Marx: comentários sobre o dinheiro no capitalismo contemporâneo. Revista Economia, vol. 12, n. 1, jan/abril 2011. Disponível em: 〈http://www.anpec.org.br/revista/vol12/vol12n1p49_70.pdf>. Acesso em: 06.08.2012.
} 
Robert Brenner ${ }^{50}$ aponta que o ritmo de crescimento do valor das ações se descola do lucro efetivo das empresas a partir da década de 1990.

Concordando com este diagnóstico, Luiz Gonzaga Belluzzo aponta que a trajetória DM-D' do capital, exposta por Marx, aproxima-se cada vez mais do D-D,51, como num processo de aperfeiçoamento do capitalismo, com o dinheiro sendo pressuposto e o resultado do processo de acumulação, prescindindo da esfera produtiva. Belluzzo aponta algumas características importantes deste novo ciclo financeiro capitalista: i) profundidade, assegurada por transações secundárias dos títulos em grande escala e frequência; ii) liquidez e mobilidade, o que permite aos investidores facilidade de entrada e saída entre diferentes ativos e segmentos do mercado, e; iii) volatilidade de preços dos ativos, resultante das mudanças frequentes de avaliação dos agentes quanto à evolução dos preços dos papeis. O autor detecta, ainda, o desenvolvimento de diversas inovações financeiras, como hedges, derivativos, "gestão de riscos", que trazem enorme potencial de formação de bolhas nos seus movimentos de alta e de colapso nos movimentos de baixa.

Esta nova lógica do capital exigiu, por sua vez, uma nova dinâmica de regulação econômica e financeira dos Estados nacionais. A nova dinâmica preconizava: i) maior liberdade para o capital; ii) maior proteção da propriedade privada e promoção do mercado; iii) limites estreitos para a atuação do Estado; iv) rigor na disciplina fiscal dos Estados, com limitações ao investimento e ao gasto social. Este conjunto de instituições era apresentado como ideal para a promoção do desenvolvimento ${ }^{52}$, devendo, por isso ser adotadas pelos Estados nacionais. Para Luís Fernando Massonetto ${ }^{53}$, o padrão normativo da expansão financeira do capitalismo é marcado, na forma, pela flexibilidade, e, no conteúdo, pela tutela jurídica da renda financeira do capital. Isto porque este padrão normativo tenderia a um melhor desempenho na redução de incertezas e na garantia da expansão financeira.

\footnotetext{
50 BRENNER, Robert. O Boom e a bolha: os Estados Unidos na economia mundial. Rio de Janeiro: Record, 2003, p. 202.

${ }^{51}$ BELLUZZO, Luiz Gonzaga. Finança global e ciclos de expansão. In FIORI, José Luís. Estados, moedas e desenvolvimento. In FIORI, José Luís (org.). Estados e moedas no desenvolvimento das nações. $2^{a}$ Ed. Petrópolis: Editora Vozes, 1999.

52 TRUBEK, David M. e SANTOS, Alvaro. The New Law and Economic Development: a critical appraisal. Nova York: Cambridge Press, 2006, pp. 5-6.

${ }^{53}$ MASSONETTO, Luís Fernando. O Direito Financeiro no Capitalismo Contemporâneo: a emergência de um novo padrão normativo. Tese de doutorado apresentada ao Departamento de Direito Econômico, Financeiro e Tributário da Faculdade de Direito da USP. São Paulo: 2006, pp. 104-105.
} 
É marcante, também a ausência de mecanismos endógenos de regulação e a centralidade da política monetária americana, ditada por instituições como o FED (Federal Reserve System, autoridade monetária americana):

A importância da política monetária americana decorre do efeito combinado dos fatores de hierarquização próprios ao período de 'mundialização do capital', da interligação dos mercados de títulos e da posição ocupada pelos déficits públicos. ${ }^{54}$

A concentração da acumulação capitalista na esfera financeira evidencia um regime específico de propriedade do capital, o capitalismo patrimonial ${ }^{55}$. A propriedade patrimonial está ligada à figura do proprietário acionista, mais especificamente ao acionista institucional possuidor de títulos de empresas. Estes proprietários se colocam numa posição exterior à produção, entretanto não são credores, ou seja, não são apenas titulares de "empréstimos" a empresas ${ }^{56}$. O seu patrimônio significa uma propriedade mobiliária (ações, títulos) ou imobiliária que foi acumulada e dirigida para o rendimento e não tem como finalidade o consumo ou a criação de riquezas. Apesar de exterior à esfera produtiva, os proprietários têm o poder de decidir sobre a divisão da riqueza produzida entre lucros, salários e renda financeira, e também decidir sobre a divisão no que diz respeito a dividendos, juros e investimento.

A exterioridade do proprietário (geralmente um investidor institucional) em face das atividades relacionadas à produção e circulação de mercadorias leva-o a "exigir da economia mais do que ela pode dar" ${ }^{25}$, isso por conta das características que observamos da exigência por rendimentos altos e a curto prazo, com liquidez e segurança para os investidores.

Da exterioridade à qual nos referimos também emerge um "poder administrativo", exercido pelos executivos e administradores dos grandes grupos empresariais, delegados dos proprietários-acionistas, que se submetem a eles e têm de responder às suas demandas de rendimento. Por sua vez, o poder administrativo é exercido sobre os

${ }^{54}$ CHESNAIS, François. (Org.). A mundialização financeira: gênese, custos e riscos. São Paulo: Xamã, 1998, p. 259.

${ }_{55}$ CHESNAIS, François (Org.). A finança mundializada. São Paulo: Boitempo, 2005, pp. 48-52.

${ }^{56}$ François Chesnais chama atenção para o caráter dual das ações. Estas são simultaneamente frações do capital de uma sociedade que dá direito a receber lucros e dividendos e também um ativo financeiro cujo valor se altera diariamente em função da dinâmica autorreferenciada dos mercados de capitais. Ver CHESNAIS, François. (Org.). A mundialização financeira: gênese, custos e riscos. Op. cit, p. 271.

${ }^{57}$ CHESNAIS, François (Org.). A finança mundializada. Op.cit, p. 61. 
assalariados, que respondem em última instância aos efeitos das normas de alta rentabilidade impostas pelas finanças, com reflexos no rigor salarial e na flexibilização do emprego.

O processo de financeirização em curso a partir dos anos 1970 teve como uma das principais consequências o aumento da fragilidade econômica dos países, refletido no grande número de abalos e crises das últimas décadas, e também no aumento da abrangência e da velocidade de contágio das crises financeiras, resultando no que Chesnais chama de vulnerabilidade sistêmica. ${ }^{58}$

No que se refere à vulnerabilidade sistêmica da economia mundial, Chesnais sustenta que a desregulamentação e a abertura financeiras provocam uma fragilização dos bancos e uma degradação da qualidade dos créditos bancários. Por sua vez, a fragilização dos bancos é consequência do fortalecimento dos investidores institucionais, principais beneficiários da desregulamentação. Os investidores institucionais, especialmente fundos de pensão e fundos de aplicação coletiva, têm absorvido boa parte da poupança das famílias - segundo o autor - que antes era capturada exclusivamente pelos bancos. ${ }^{59}$

As fontes da fragilidade sistêmica são ${ }^{60}$ :

i) Valor nominal extraordinariamente elevado dos ativos financeiros, que é, em boa parte, fictício, descolado dos ativos da economia real;

ii) Os abalos financeiros levam à necessidade de liquidez, que tem de ser suportada pelos sistemas nacionais de crédito, que têm mais dificuldade de cumprir este papel;

iii) Generalização do comportamento dos mercados financeiros para outros setores, como o mercado imobiliário e de matérias-primas (commodities), como demonstra a crise dos alimentos de 2007 e a crise do setor imobiliário americano no ano posterior;

\footnotetext{
${ }^{58}$ CHESNAIS, François. (Org.). A mundialização financeira: gênese, custos e riscos. São Paulo: Xamã, 1998, p. 249.

${ }^{59}$ Ibidem, p. 277.

${ }^{60}$ Ibidem, pp. 263-265.
} 
iv) Desregulamentação dos mercados financeiros emergentes, que acabou criando economias frágeis nos quais os abalos financeiros se propagam de forma contagiosa.

O aumento da vulnerabilidade das economias nacionais e a multiplicação de abalos e crises teve um efeito particularmente perverso nos países em desenvolvimento, inclusive em países da América Latina, como o Brasil. Estes países tiveram a sua capacidade de desenvolvimento minada pela estrutura financeira, particularmente por conta da piora na sua dependência externa e da crise fiscal resultante do estabelecimento de altas taxas de juros decorrentes da necessidade de atração de capitais. Vejamos.

A reciclagem dos petrodólares pelos bancos europeus na década de $1970^{61}$ é também a porta de entrada dos países subdesenvolvidos para sua inserção na mundialização financeira. Naquela década, a forma de regulação dos fluxos de capitais, com controles de câmbio e das flutuações das divisas favoreceu os financiamentos externos que tinham a forma de empréstimos bancários. O setor público foi o principal destinatário, especialmente em países que seguiram estratégias de industrialização voltadas para o mercado interno, como é o caso da América Latina. Na década seguinte, os fluxos foram praticamente interrompidos por conta da crise da dívida destes países, enquanto que nos anos 1990, o financiamento será principalmente de fluxos privados sob a forma de investimentos diretos externos ${ }^{62}$ e investimentos em carteira ${ }^{63}$, atraídos por fortes taxas de juros.

Vanessa Correa e Niemeyer Almeida Filho apontam que esta configuração dos fluxos financeiros potencializa a vulnerabilidade externa dos países da América Latina, isso porque estes recursos apresentam viés de curto prazo, na medida em que sempre as decisões sobre a sua aplicação dependem da conjuntura, do comportamento dos juros e

\footnotetext{
${ }^{61}$ Inundados de dólares provenientes do aumento do preço do petróleo no mercado internacional, os países da OPEP os investia no sistema financeiro estadunidense (Nova York) e inglês (Londres). Os bancos, por sua vez tornavam a emprestar estes dólares aos países do chamado terceiro mundo. A este processo convencionou-se chamar de reciclagem dos petrodólares.

62 "Os investimentos estrangeiros podem ser efetuados sob a forma de investimentos diretos ou de investimentos em carteira. O investimento direto é constituído quando o investidor detém $10 \%$ ou mais das ações ordinárias ou do direito a voto numa empresa; e considera-se como investimento em carteira quando ele for inferior a 10\%." Definição extraída do sítio eletrônico da Receita Federal do Brasil. Disponível em <http://www.receita.fazenda.gov.br/aduana/IDE/IDEBrasilCuba/ide.htm>. Acesso em 04.05.2014.

${ }^{63}$ CAMARA, Mamadou; SALAMA, Pierre. A inserção diferenciada - com efeitos paradoxais - dos países em desenvolvimento na mundialização financeira. In CHESNAIS, François (Org.). A finança mundializada. São Paulo: Boitempo, 2005, pp. 201-202.
} 
dos títulos nos mercados centrais, especialmente o americano. Assim, quanto maior o peso dos capitais com perfil especulativo e de alta flexibilidade no Balanço de Pagamentos de um país periférico, maior vulnerabilidade deste país, na medida em que se sujeita a bruscas reversões de recursos. ${ }^{64}$

Camara e Salama corroboram esta visão ao apontarem que existe uma forte correlação entre o fluxo de capitais estrangeiros e a elevação das taxas de juros reais nos anos 90. Isso significa que uma conjuntura favorável à entrada desses capitais especulativos (juros altos) é também desfavorável aos investimentos locais. Assim, os autores sustentam que existe uma relação de substituição entre o capital estrangeiro e o doméstico, ao invés de uma relação de complementaridade. Ou seja, a forte entrada de capital externo não é uma fonte de acumulação local, nem serve ao desenvolvimento nacional ou mesmo à transferência de tecnologia estrangeira ao país periférico. ${ }^{65}$

Ainda segundo estes autores, as crises geradas na América Latina nos anos 1990 são crises relacionadas a estas restrições no balanço de pagamentos. O modelo de desenvolvimento adotado nestes países, fortemente dependentes de financiamento externo, gera uma propensão à instabilidade e à produção de crises financeiras, que se tornam mais agudas no contexto da acumulação predominantemente financeira. ${ }^{66}$

A própria manipulação da taxa de juros como um instrumento para evitar desequilíbrios externos é prejudicial aos países da região pelas suas implicações na dívida pública. François Chesnais ${ }^{67}$ aponta a centralidade dos mercados secundários de títulos da dívida dos países centrais para o processo de financeirização. Para o autor, surge novo tipo de rentista: o detentor dos títulos da dívida pública. Em paralelo, a situação fiscal dos países se complica: a alta taxa de juros leva a uma queda na receita por conta da redução da atividade produtiva e do nível de emprego, ao tempo em que as taxas de juros tornam

\footnotetext{
${ }^{64}$ CORRÊA, Vanessa Petrelli; ALMEIDA FILHO, Niemeyer. Fragilidade financeira e vulnerabilidade externa em países periféricos. In CASSIOLATO, José Eduardo; MATOS, Marcelo Pessoa de; LASTRES, Helena M. M. Desenvolvimento e mundialização - O Brasil e o pensamento de François Chesnais. E-papers: Rio de Janeiro, 2014, p. 268.

${ }^{65}$ CAMARA, Mamadou; SALAMA, Pierre. A inserção diferenciada - com efeitos paradoxais - dos países em desenvolvimento na mundialização financeira. In CHESNAIS, François (Org.). A finança mundializada. São Paulo: Boitempo, 2005, p. 209.

${ }^{66}$ Ibidem, pp. 212-219.

${ }^{67}$ CHESNAIS, François. (Org.). A mundialização financeira: gênese, custos e riscos. São Paulo: Xamã, 1998, pp. 260-261; e CHESNAIS, François (Org.). A finança mundializada. São Paulo: Boitempo, 2005, pp. 3940.
} 
o financiamento dos déficits públicos mais caros, surgindo uma "bola de neve" da dívida, nos dizeres do autor.

Já nos países subdesenvolvidos, o autor mostra que além destas consequências, o crescimento da dívida pública destes países, pós-1979, abriu caminho para uma maior dominação econômica dos países centrais, bem como abriu portas para que fossem impostas políticas ditas de ajuste estrutural e processos de desindustrialização. Para José Luis Fiori, estes Estados tiveram a sua capacidade de definir horizontes e criar novos espaços de acumulação fortemente afetada pelo encurtamento dos recursos internos e externos. $^{68}$

\subsubsection{Financeirização e sistemas de previdência}

Vimos até agora que as mudanças estruturais no capitalismo durante as últimas décadas do século XX alteraram substancialmente a regulação dos fluxos financeiros, com impactos na regulação do mercado de trabalho, no crescimento dos países e também na capacidade de financiamento dos Estados e na sua dependência em relação aos grupos financeiros.

A forma de a sociedade lidar com as incertezas ${ }^{69}$ não fica imune a estas transformações de final de século. Para Sara Granemann ${ }^{70}$, o Welfare State e as políticas sociais amplas e de alcance universal tornam-se não só impróprios como também obstáculos para a realização das exigências do capital financeiro:

Para a dinâmica da acumulação do grande capital comandada pelas finanças, os equipamentos públicos formatados com base no acesso universal e que (...) respondiam ao preceito fordista do consumo em massa, da circulação da moeda e da luta da força de trabalho por melhores condições de vida e trabalho, tornam-se obsoletos. ${ }^{71}$

Assim, o movimento que leva à concentração da riqueza na esfera financeira, à crise nas instituições de Bretton Woods e do próprio Welfare State Keynesiano, enfraquece os

\footnotetext{
${ }^{68}$ FIORI, José Luís. Para repensar o papel do Estado sem ser um neoliberal. In Revista de Economia Política, vol. 12, nº 1, janeiro/março de 1992, p. 83.

${ }^{69}$ Por incertezas, referimo-nos aos riscos sociais, especialmente àqueles que retiram dos trabalhadores a possibilidade de vender a sua força de trabalho: acidentes, doença, envelhecimento, dentre outros.

${ }^{70}$ GRANEMANN, Sara. Políticas Sociais e Financeirização dos Direitos do Trabalho. In Revista da Faculdade de Serviço Social da Universidade do Estado do Rio de Janeiro, nº 20, 2007.

${ }^{71}$ Ibidem, p. 58.
} 
regimes de previdência de cunho contributivo e solidário, fortalecendo os regimes de capitalização $^{72} \mathrm{e}$, assim, tornando gigantes alguns players econômicos que antes não tinham tanto destaque: os fundos de pensão.

Como sugerido acima, há dois padrões possíveis de estruturação dos regimes previdenciários: o de repartição e de capitalização. No regime de repartição existe um pacto de gerações, no qual os segurados ativos (geração atual) pagam os benefícios dos segurados inativos (geração passada). O pagamento dos próprios benefícios depende da geração futura. Leda Paulani ${ }^{73}$ aponta o regime de repartição como herdeiro da história e dos princípios do Welfare State. O sistema tem na previdência pública seu instrumento de atuação, e, além da solidariedade intergeracional, é balizado por outros dois pilares.

O primeiro é a universalidade do benefício. Há um vínculo menos rígido entre o acesso ao benefício e a contribuição ao sistema. O outro é a participação do Estado no sistema tripartite, pois faz parte da característica desse regime a possibilidade de existência de déficits, que devem ser custeados através da coleta normal de impostos. Ainda segundo a autora, o sistema será tão mais equilibrado quanto maiores forem o emprego, a renda, o nível do salário médio real e, por consequência, a participação dos salários na renda. A partir destes apontamentos, pode-se concluir que a sustentação do regime está intimamente ligada à possibilidade de expansão material do capitalismo.

Já no regime de capitalização, cada geração constitui as reservas para suportar seus próprios benefícios. Cada trabalhador, durante sua fase ativa, deve gerar o montante necessário para suportar o custo dos benefícios da sua própria aposentadoria. Aqui, para Maria Jardim ${ }^{74}$, estão presentes as ideias de auto empreendedorismo e individualismo, visto que a capitalização favorece o aparecimento do "individualismo patrimonial". O vínculo entre contribuição e benefício é extremamente reforçado. São formadas caixas de aposentadoria separadas das contas do empregador nas quais as reservas (provenientes das contribuições patronais ou salariais) são acumuladas e valorizadas no mercado financeiro.

\footnotetext{
72 PAULANI, Leda Maria. Seguridade social, regimes previdenciários e padrão de acumulação: uma nota teórica e uma reflexão sobre o Brasil. In FAGNANI, Eduardo; HENRIQUE, Wilnês; e LÚCIO, Clemente Ganz (orgs.). Previdência Social: Como incluir os excluídos. LTr: São Paulo, 2008.

${ }^{73}$ Ibidem, pp. 24-25.

${ }^{74}$ JARDIM, Maria A. Chaves. Entre a solidariedade e o risco: sindicatos e fundos de pensão em tempos de governo Lula. São Paulo: Annablume, Fapesp, 2009, pp. 35-36.
} 
Se o regime de repartição está ligado às origens do Welfare State, a história mostra que o regime de capitalização é herdeiro das sociedades e associações mutualistas, e dos sistemas estatais voltados para categorias específicas de profissionais. ${ }^{75}$

Hoje, os principais operadores dos sistemas de capitalização são os fundos de pensão, que funcionam acumulando contribuições calculadas sobre os salários dos trabalhadores, com o objetivo de conceder, quando da cessação do trabalho, uma pensão regular e estável. Os recursos arrecadados são centralizados nas mãos dos gestores destes fundos. Dessa maneira, aponta Chesnais, a poupança acumulada se transforma em capital ${ }^{76}$, que é investido preponderantemente em títulos e no mercado mobiliário, indo ao encontro do regime de acumulação patrimonial explicado anteriormente.

Os gestores dos fundos de pensão, desta forma, têm o objetivo de garantir, com razoável grau de segurança, o maior rendimento possível. Sobre estes gestores são exercidas pressões típicas do mercado, como a necessidade de liquidez - os fundos precisam ter capital disponível para pagar as pensões e aposentadorias devidas naquele determinado momento -, tolerância ao risco e horizonte temporal de antecipação das perspectivas de rendimento, que são avaliadas a partir do cálculo atuarial pertinente à estrutura etária dos beneficiários. ${ }^{77}$ Como agentes do sistema financeiro, os fundos têm interesse em altas taxas de juros reais e salários deprimidos. ${ }^{78}$ Isso porque, conforme explica Chesnais, com a aceleração do processo de financeirização dos grupos industriais, o horizonte temporal da realização dos lucros destes grupos passa a ser de curto ou curtíssimo prazo. $^{79}$

François Chesnais demonstra que a titulização, a alta das taxas de juros e a liberação dos movimentos dos capitais coincidiram com o momento em que os fundos de pensão, em decorrência do alto volume de recursos acumulados, buscavam oportunidades de aplicação em larga escala. Por isso, estes foram os primeiros beneficiários da

\footnotetext{
${ }^{75}$ PAULANI, Leda Maria. Seguridade social, regimes previdenciários e padrão de acumulação: uma nota teórica e uma reflexão sobre o Brasil. In FAGNANI, Eduardo; HENRIQUE, Wilnês; e LÚCIO, Clemente Ganz (orgs.). Previdência Social: Como incluir os excluídos. LTr: São Paulo, 2008, pp. 24-25.

${ }^{76}$ CHESNAIS, François (Org.). A finança mundializada. São Paulo: Boitempo, 2005, p. 51.

77 SAUVIAT, Catherine. Os fundos de pensão e os fundos mútuos: principais atores da finança mundializada e do novo poder acionário. In: CHESNAIS, François (Org.). A finança mundializada. São Paulo: Boitempo, 2005, p. 111.

${ }^{78}$ PAULANI, op. cit., p. 26.

${ }^{79}$ CHESNAIS, François. (Org.). A mundialização financeira: gênese, custos e riscos. São Paulo: Xamã, 1998, p. 261.
} 
desregulamentação monetária e financeira. Ao longo dos anos 80, os investidores institucionais tomam o protagonismo do sistema bancário na centralização financeira:

No caso dos Estados Unidos, a formação das caixas de previdência de empresas ou da administração pública remonta às vezes aos anos 20 , mas mais frequentemente ao período 1940-50. Sua emergência nos países anglo-saxões e no Japão como principais atores da finança de mercado no fim dos anos 70 é consequência da escolha política feita nesses países, ao fim da Segunda Guerra Mundial, em favor dos sistemas de previdência privados. Mas, nos anos 70, os estímulos fiscais reforçaram sua atratividade. ${ }^{80}$

Para Chesnais, a migração progressiva dos sistemas de previdência por repartição para sistemas de capitalização, é uma das exigências para a estruturação do mercado financeiro nas últimas décadas do século XX. Isto porque quantidades significativas de poupança salarial escapam do mercado financeiro com o regime de repartição. ${ }^{81}$

Em consonância com esta tendência, o Banco Mundial lança em 1994 um importante relatório intitulado Averting the Old Age Crisis: Policies to Protect the Old and promote Growth. O relatório indica que as mudanças na estrutura etária dos países, com o progressivo envelhecimento da população, tornariam os sistemas de previdência por repartição cada vez mais custosos e deficitários aos Estados, e aponta para a necessidade de adoção de sistemas de previdência por capitalização.

Robin Blackburn discorda desta recomendação. Para Blackburn, esta é uma previsão alarmista e baseada numa visão neoliberal da economia, que tem como objetivo direcionar a poupança dos trabalhadores aos fundos comerciais de pensão, assumindo como pressuposto o fato de que a pensões só podem ser fornecidas por estes fundos geridos pela indústria de serviços financeiros. Para o autor, se é verdade que o envelhecimento da população aumenta o tempo em que as pessoas dependem das pensões, as mudanças ocasionadas com o avanço da medicina e a diminuição da taxa de natalidade pode também aumentar o tempo de idade ativa e consequentemente de contribuição dos trabalhadores, bem como reduzir o numero de dependentes de cada trabalhador. Ainda, os principais problemas do capitalismo não dizem respeito, em sua

\footnotetext{
${ }^{80}$ CHESNAIS, François (Org.). A finança mundializada. São Paulo: Boitempo, 2005, p. 41.

${ }^{81}$ CHESNAIS, François. (Org.). A mundialização financeira: gênese, custos e riscos. São Paulo: Xamã, 1998, p. 262.
} 
visão, à duração do trabalho ativo de cada trabalhador, mas principalmente às taxas de desemprego. Formas de organização do trabalho que favoreçam o emprego e não marginalizem o trabalho dos mais velhos aumentariam as bases de arrecadação dos sistemas previdenciários ${ }^{82}$.

In modern societies economic provision for those in retirement is bound to be costly but there are ways of anticipating and covering this cost that could encourage a more responsible pattern of social relations, one that combats inequality and unemployment by encouraging sustainable development. ${ }^{83}$

De qualquer forma, o avanço destes investidores institucionais em escala global é comprovado pelo alto volume de capital que centralizam. Na virada do século, os fundos de pensão chegaram a acumular ativos no valor de 13 trilhões de dólares, enquanto a soma do PIB global era de 28 trilhões e a soma do valor das ações 23 trilhões. $^{84}$

Catherine Sauviat ${ }^{85}$ indica que os Fundos de Pensão e os Fundos Mútuos ${ }^{86}$ são os dois componentes mais dinâmicos da finança mundial. São os principais acionistas e principais emprestadores de empresas e também do Estado, o que lhes confere um duplo poder, de proprietário e credor. Ao longo da década de 90, os fundos tomam o lugar das grandes seguradoras como os principais investidores institucionais do mercado financeiro. No final desta mesma década, os haveres dos investidores institucionais representavam $140 \%$ do $\mathrm{PIB}$ dos países da $\mathrm{OCDE}^{87}$, crescendo sempre a um ritmo sustentado.

A emergência dos Fundos de Pensão, viabilizada pela desregulamentação das finanças, alimenta o crescimento do mercado financeiro, sendo estes os principais responsáveis

\footnotetext{
${ }^{82}$ BLACKBURN, Robin. Banking on Death or investing in life: the history and future of pensions. Verso. Nova York, 2002, pp. 9-20.

${ }^{83}$ Ibidem, p. 27.

${ }^{84}$ Ibidem, p. 6.

85 SAUVIAT, Catherine. Os fundos de pensão e os fundos mútuos: principais atores da finança mundializada e do novo poder acionário. In: CHESNAIS, François (Org.). A finança mundializada. São Paulo: Boitempo, 2005, pp. 109-110.

${ }^{86}$ Os Fundos Mútuos não gerem patrimônio próprio, mas constituem e administram uma carteira coletiva de valores mobiliários, subscritos por investidores individuais e institucionais (fundos de pensão, seguradoras etc.). Três quartos desses valores são detidos por famílias e o quarto restante pelos demais investidores institucionais. Ver Ibidem, pp. 114-115.

${ }^{87}$ CHESNAIS, François (Org.). A finança mundializada. São Paulo: Boitempo, 2005, pp. 43-44.
} 
pelas transações em ações e obrigações, a maior parte delas nos mercados secundários. ${ }^{88}$ A busca por rendimentos cada vez mais altos aumenta a velocidade e o volume das transações, contribuindo para as crises financeiras cada vez mais frequentes. ${ }^{89}$

Não à toa, Sauviat fala em um novo poder acionário destes grandes investidores institucionais. Eles tornaram-se os principais acionistas das empresas, em especial das maiores, que recorrem à poupança pública, tendo feito das ações um instrumento privilegiado tanto de suas aplicações domésticas como internacionais. As empresas têm substituído os bancos como intermediários financeiros através da securitização das suas dívidas. O novo poder acionário traz consequências para a organização da economia e para as relações capital-trabalho.

A primeira delas é uma ameaça à soberania dos Estados e à capacidade decisória das empresas. Afinal, a concentração das ações nas mãos dos investidores institucionais conferiu-lhes o poder de reivindicar coletivamente suas prerrogativas de acionistas e de exigir das empresas e de seus dirigentes níveis mais elevados de retorno sobre a aplicação ${ }^{90}$.

Outra consequência é a afirmação de uma concepção financeirizada da empresa. Esta torna-se uma coleção de ativos divisíveis e líquidos, prontos para serem cedidos ou comprados de acordo com as oportunidades de rendimento financeiro. Há uma ameaça permanente de retirada por parte dos fundos, que podem se livrar de todo o compromisso financeiro da noite para o dia em nome da necessidade de liquidez. Além disso, os investidores têm o poder de avaliar publicamente as empresas com ajuda de métodos e instrumentos padronizados. Isso leva Sauviat ${ }^{91}$ a afirmar que o novo poder acionário trata-se de um poder social mais amplo, que se exerce de certo modo do exterior e se encarna na afirmação da primazia dos interesses dos acionistas sobre qualquer outro interesse.

\footnotetext{
88 SAUVIAT, Catherine. Os fundos de pensão e os fundos mútuos: principais atores da finança mundializada e do novo poder acionário. In: CHESNAIS, François (Org.). A finança mundializada. São Paulo: Boitempo, 2005, p. 116.

${ }^{89}$ Para uma interessante análise sobre a natureza e evolução das crises financeiras durante as últimas décadas do século XX, ver CHESNAIS, François. (Org.). A mundialização financeira: gênese, custos e riscos. São Paulo: Xamã, 1998, pp. 11-31.

${ }^{90}$ SAUVIAT, op. cit., pp. 121-123.

${ }^{91}$ Ibidem, pp. 123-124.
} 
Os administradores das empresas, por sua vez, não ficam imunes ao fortalecimento dos investidores institucionais. Afinal, são eles os pressionados pela necessidade de apresentação de resultados compatíveis com os objetivos do mercado. A forma de remuneração dos administradores se modifica, para adaptar-se à nova realidade. É neste sentido que surgem as Stock-options ${ }^{92}$, como forma de remuneração que contorna o novo poder acionário, harmonizando os interesses dos administradores e dos acionistas. Entretanto, diversos escândalos que explodiram nas últimas décadas demonstram que estes resultados são obtidos, muitas vezes, à custa de grandes acrobacias contábeis, como nos casos Enron, WorldCom, e Tyco, nos quais administradores "enganaram" os acionistas com o objetivo de maximizar sua remuneração de curto prazo mediante a valorização das ações do grupo.

Por último, o novo poder acionário agudiza contradições nas relações capital trabalho. Como visto, o horizonte das pensões e aposentadorias individuais dos trabalhadores passa a depender de uma exploração cada vez maior dos trabalhadores enquanto classe. Afinal, a gestão das empresas passa a privilegiar cada vez mais os esquemas que vão ao encontro das "preferências" dos investidores, tais como redução de custos, reestruturação dos grupos em torno dos segmentos de atividades mais rentáveis e programas recorrentes de recompra de ações. Isso se traduz, no mundo do trabalho, em segmentação crescente do mercado de trabalho, aumento das desigualdades na remuneração dos assalariados, degradação das condições de trabalho dos assalariados, e instabilidade no emprego. ${ }^{93}$

\section{$1.2 \mathrm{O}$ caso brasileiro: padrão de financiamento do ciclo desenvolvimentista}

Neste item, nos propomos a analisar a forma como o Brasil se inseriu nas mudanças do capitalismo da segunda metade do século $\mathrm{XX}$, especialmente no que diz respeito ao financiamento da atividade econômica e do desenvolvimento do país. Poderemos observar que as mudanças no contexto internacional no que tange à mobilidade de capitais e à disponibilidade de financiamento provocaram alterações profundas na capacidade de o Estado brasileiro induzir e planejar a atividade econômica. Entretanto,

\footnotetext{
92 As Stock-options são uma forma de remuneração de gestores através de contratos de opções de compra de ações da própria empresa. Dá-se ao gestor a opção (mas não o dever) de comprar ações da empresa para a qual trabalha a um determinado valor.

${ }^{93}$ CHESNAIS, François (Org.). A finança mundializada. São Paulo: Boitempo, 2005, pp. 55-56; e SAUVIAT, Catherine. Os fundos de pensão e os fundos mútuos: principais atores da finança mundializada e do novo poder acionário. In CHESNAIS, François (Org.). A finança mundializada. São Paulo: Boitempo, 2005, pp. 126129.
} 
veremos também que fatores internos também foram decisivos para a constituição e exaustão de um determinado modelo econômico, calcado na presença decisiva do fundo público no financiamento da acumulação de capital no país.

A hipótese da combinação de fatores internacionais e domésticos na explicação da performance do capitalismo brasileiro é apresentada por Ricardo Carneiro em seu livro Desenvolvimento em Crise. ${ }^{94} \mathrm{O}$ economista elenca três fatores externos como importantes na determinação da dinâmica nacional do desenvolvimento:

i) Dinâmica tecnológica (grau de disseminação e acesso às tecnologias produtivas dominantes);

ii) Organização das finanças internacionais (disponibilidade de financiamento), e;

iii) Ordem econômica internacional (regras relativas ao comércio e finanças).

Para ele, o ciclo econômico vivido pelo capitalismo nas décadas após a II Guerra Mundial favoreceu a inserção e a performance das economias da periferia do sistema, como a brasileira, especialmente por conferir um maior grau de autonomia à política econômica doméstica:

A consideração conjunta dos fatores de estímulo ao crescimento oriundos do contexto internacional permite identificar como conjunturas mais favoráveis aos países periféricos aquelas que incluem a estabilidade do paradigma tecnológico e uma ordem internacional similar à de Bretton Woods, caracterizada pelo estímulo ao comércio e financiamento de longo prazo, bem como pela possibilidade de maior autonomia das políticas domésticas. Combinações nas quais não está presente o conjunto desses elementos, como as observadas nos demais períodos, produzem, além de crescimento global menor, um dinamismo bastante diferenciado entre países. $^{95}$

Por outro lado, contribuem para explicar o desempenho do capitalismo brasileiro, fatores internos como: i) Padrão de crescimento (combinação de setores produtivos líderes do processo); ii) Padrão de financiamento (capacidade de financiar o

\footnotetext{
${ }^{94}$ CARNEIRO, Ricardo. Desenvolvimento em Crise: a economia brasileira no último quarto do século $X X$. Editora Unesp, IE Unicamp. São Paulo, 2002, pp. 28-34.

95 Ibidem, p. 32.
} 
investimento nos volumes e prazos requeridos), e; iii) Papel do Estado em sua intervenção na economia.

Decerto que a presença forte do Estado brasileiro na economia (especialmente entre as décadas de 1930 e 1980), seja em sua atuação direta no domínio econômico, através de suas empresas estatais, seja através do papel ativo no financiamento via bancos públicos e endividadamento externo, seja na escolha de setores produtivos que dirigiriam o processo de desenvolvimento, é destacada por diversos autores.

Para Peter Evans ${ }^{96}$, houve, no Brasil, uma tríplice aliança entre capital internacional, capital estatal e capital privado nacional, este último com uma participação muito menor, no financiamento da industrialização e do desenvolvimento. Conforme a leitura do autor, coube ao Estado, através da coação e do incentivo, redirigir a racionalidade global do capital internacional, com vistas à acumulação local.

Em sentido semelhante, Maria da Conceição Tavares e José Carlos Miranda apontam que:

[a] intervenção econômica do Estado é uma constante no desenvolvimento capitalista brasileiro. A combinação de políticas protecionistas do grande capital nacional e estrangeiro, de financiamento direto da grande burguesia nacional e de fomento ou restrição à produção estatal de commodities internacionais (minério, aço e petróleo), é que varia com as modificações que ocorrem na inserção internacional da economia brasileira. ${ }^{97}$

Para estes autores, a formação da burguesia industrial brasileira dependeu do crédito das instituições públicas nacionais. Sua estruturação patrimonial baseou-se em mecanismos ad hoc de criação de crédito e de finance pelo Estado. Fiori ${ }^{98}$ acrescenta que, em decorrência da atrofia do sistema financeiro privado, o processo de desenvolvimento

96 EVANS, Peter. A tríplice aliança: as multinacionais, as estatais e o capital nacional no desenvolvimento dependente brasileiro. Rio de Janeiro: Zahar, 1980.

${ }^{97}$ TAVARES, Maria da Conceição e MIRANDA, José Carlos. Brasil: estratégias de conglomeração. In FIORI, José Luís. Estados, moedas e desenvolvimento. In FIORI, José Luís (org.). Estados e moedas no desenvolvimento das nações. $2^{\text {a }}$ Ed. Petrópolis: Editora Vozes, 1999, p. 337.

98 Trata-se do que Fiori chamou de "fuga para frente" em sua tese de doutorado, posteriormente reeditada em: FIORI, José Luís. O vôo da coruja: para reler o desenvolvimentismo brasileiro. Ed. Record. Rio de Janeiro, 2003. Ver também: FIORI, José Luís. Para repensar o papel do Estado sem ser um neoliberal. In Revista de Economia Política, vol. 12, nº 1, janeiro/março de 1992, pp.76-89. 
nacional passou sempre pela inflação ou pelo endividamento externo. Este padrão de financiamento, por sua vez, fragilizou o Estado no plano fiscal e se tornaria insustentável a partir da década de $70 .{ }^{99}$ Esta visão é corroborada por Torres Filho e Costa:

$$
\begin{aligned}
& \text { [a] crise da dívida externa dos anos } 1980 \text { levou não só às } \\
& \text { maxidesvalorizações cambiais e consequentemente à mudança de } \\
& \text { patamar da taxa de inflação, mas também à desorganização das } \\
& \text { finanças públicas. }{ }^{100}
\end{aligned}
$$

Ricardo Carneiro ${ }^{101}$ aponta que o aparato regulador, combinado com a propriedade de empresas produtivas e financeiras, conferiu ao Estado brasileiro uma ampla capacidade de intervenção e direção no domínio econômico. Para o autor, o investimento do setor produtivo estatal, em conjunto com o gasto público tradicional, atuou como indutor do investimento privado. E, graças a esta atuação estatal, o capitalismo brasileiro conseguiu ter mais dinamismo, crescimento e diferenciação da estrutura produtiva do que seria possível apenas pelas forças de mercado.

Veremos nos subitens seguintes, de forma mais pormenorizada, como se comportou o Estado brasileiro no financiamento e direcionamento do capital durante o ciclo desenvolvimentista até o esgotamento do modelo no último quarto do século XX.

\subsubsection{0-64: Restrições ao financiamento}

A década de 1930 marca uma importante inflexão no capitalismo brasileiro, com o deslocamento do centro dinâmico da economia. Até então o elemento essencial na determinação do nível de renda e da atividade produtiva era a demanda externa, concentrada, sobretudo, no setor agroexportador. Contudo, após a crise de 1929 - que provocou uma drástica redução da procura internacional, e consequentemente da procura e dos preços do principal produto brasileiro, o café - o elemento determinante

\footnotetext{
99 FIORI, José Luís. O nó cego do desenvolvimentismo brasileiro. In Novos Estudos CEBRAP no 40, novembro de 1994, pp. 125-144.

100 TORRES FILHO, Ernani Teixeira, e COSTA, Fernando Nogueira da. Financiamento de Longo Prazo no Brasil: um mercado em transformação. Revista Economia e Sociedade, 2012, p. 9.

${ }_{101}$ CARNEIRO, Ricardo. Desenvolvimento em Crise: a economia brasileira no último quarto do século XX. Editora Unesp, IE Unicamp. São Paulo, 2002, p. 40.
} 
do nível de renda passa a ser a atividade produtiva relacionada ao mercado interno, mais precisamente o consumo e o investimento doméstico ${ }^{102}$.

Celso Furtado, em seu Formação Econômica do Brasil, observa que esta seria a segunda etapa de um processo de desenvolvimento de uma região de escassa população e abundantes recursos naturais, como o Brasil. ${ }^{103}$ Furtado nota que, no Brasil, a política do governo brasileiro pós-crise de 1929, ao financiar a compra e queima de toneladas de café acabou ajudando na manutenção dos níveis de emprego e renda na economia brasileira.

O mercado interno passará a ser o responsável pelo atendimento à demanda interna por bens de consumo, inclusive manufaturados, que se encontrava relativamente alta. Daí para frente, respondendo a um estrangulamento externo, o país passa a investir, nas décadas subsequentes, numa política de industrialização por substituição de importações. Como produto desta política, o setor industrial ganha cada vez mais relevância na composição da riqueza, passando de 22,7\% do PIB nacional em 1928/29, para 36,1\% em 1940/45. Em contraposição, a agricultura perde importância relativa, passando de $52,5 \%$ do PIB para $37,1 \%$ no mesmo período. ${ }^{104}$

No contexto da industrialização por substituição de importações, o Estado assume um papel importante, exercendo quatro funções principais ${ }^{105}$ : i) adequação do arcabouço institucional à indústria, com a legislação trabalhista e criação de mecanismos institucionais para direcionar capitais do setor agrícola para o industrial; ii) geração de infraestrutura básica, especialmente de transportes e energia; iii) fornecimento dos insumos, com a criação de estatais como a Companhia Vale do Rio Doce (CVRD) e Companhia Siderúrgica Nacional, e; iv) captação e distribuição de poupança, com o sistema financeiro público.

No que diz respeito à função do financiamento, Carneiro enfatiza que ela ganha em importância à medida que o processo de industrialização avança em direção aos setores mais complexos da indústria, intensivos em tecnologia e extensivos em trabalho, pois

\footnotetext{
${ }^{102}$ GREMAUD, Amaury Patrick; VASCONCELOS, Marco Antonio Sandoval; TONETO JUNIOR, Rudinei. Economia Brasileira contemporânea. $7^{\mathrm{a}}$ edição. 11 $1^{\mathrm{a}}$ reimpressão. Editora Atlas. São Paulo, 2014, pp. 347-349.

${ }^{103}$ FURTADO, Celso. Formação Econômica do Brasil. Edição comemorativa: 50 anos. Companhia das Letras. São Paulo: 2009, pp. 324-328.

${ }^{104}$ GREMAUD; VASCONCELOS; TONETO JUNIOR, op. cit., p. 348.

${ }^{105}$ Ibidem, pp. 359-360
} 
estes setores exigem maiores volumes de capital, com prazo de maturação e retorno dilatados. ${ }^{106}$ Também cresce em importância o sistema de financiamento quando se analisa a independência do crescimento perante condicionantes externas. Assim, caso não haja um sistema financeiro doméstico capaz de prover crédito em volumes e prazos demandados pelas atividades econômicas, recria-se a dependência. ${ }^{107}$

O setor privado brasileiro foi incapaz de desenvolver um sistema bancário que pudesse responder a estas demandas, cada vez mais complexas. Pelo contrário, Fiori aponta que a atrofia do setor bancário brasileiro transferiu para o crédito público a responsabilidade pelo financiamento dos grandes projetos de investimento indispensáveis à industrialização. O Estado, por sua vez, recorria ora à inflação, ora ao endividamento externo para sustentar o processo de crescimento, que, assim, se constituía sobre bases extremamente frágeis. ${ }^{108}$

Carneiro concorda no diagnóstico e mostra que através da criação e gestão de fundos de poupança compulsória, além da criação de instituições especiais de crédito, o Estado tornou os recursos fiscais e parafiscais os principais responsáveis pelo sistema doméstico de financiamento a longo prazo. ${ }^{109}$

Pode-se observar, todavia, que as possibilidades para financiamento do próprio Estado não foram homogêneas nem isentas de dificuldades. No período pré-64, havia uma "dificuldade intrínseca do Estado, dado o quadro institucional daquele momento histórico, em financiar-se junto ao público, ou mesmo externamente, mediante a emissão de títulos da dívida pública". ${ }^{110}$

No âmbito interno, as principais dificuldades eram a já citada pouca penetração do sistema financeiro privado e a vigência da Lei da Usura, de 1933, que limitava a taxa de juros nominal a $12 \%$ ao ano, praticamente inviabilizando os empréstimos a longo prazo.

\footnotetext{
${ }^{106}$ CARNEIRO, Ricardo. Desenvolvimento em Crise: a economia brasileira no último quarto do século $X X$. Editora Unesp, IE Unicamp. São Paulo, 2002, pp. 37-38.

${ }^{107}$ Ibidem, p. 38.

108 Para Fiori, contudo, corroborando a posição de Maria da Conceição Tavares, a posição do Estado brasileiro no financiamento foi passiva. Isto significa que ele cumpriu a função de aportar massas de capitais através especialmente do crédito subsidiado, sem conseguir articular financeiramente a estratégia de industrialização. Isto se deveu a uma posição subordinada do capital estatal na aliança com o capital privado, especialmente estrangeiro, que tinha uma a postura antiestatal que impediu as tentativas de realizar uma centralização financeira mais ativa por parte do setor público. Ver FIORI, José Luis. O nó cego do desenvolvimentismo brasileiro. Novos Estudos Cebrap, N.40, 1994, pp. 127-129.

${ }^{109}$ CARNEIRO, op. cit., p. 38.

110 PIRES, Julio Manuel. Uma visão histórica sobre o problema do padrão de financiamento da economia brasileira. Ensaios FEE, Porto Alegre, v. 25, n. 2, pp. 545-560, out. 2004, p. 547.
} 
Do ponto de vista externo, não havia um mercado de crédito privado de âmbito internacional. O financiamento externo só vai adquirir maior importância para os países em desenvolvimento a partir do final da década de 1960. Até então, o governo era obrigado a fazer uso de créditos externos de curto prazo e swaps. ${ }^{111}$ Internamente, o governo se financiava a partir de legislações impositivas, como a emissão compulsória de títulos junto aos setores previdenciário e financeiro. ${ }^{112}$

No período pré-64, arrecadação tributária cresceu modestamente, mas de forma constante. Entretanto, cresceu de forma insuficiente para cobrir as despesas geradas com o projeto de sustentação e aceleração do crescimento industrial. Elevação do endividamento externo foi relativamente pequena, segundo o autor: $80 \%$. Enquanto isso, houve redução da relação dívida interna/PIB ${ }^{113}$.

Todavia, o volume de recursos exigidos naquela fase do processo de industrialização brasileira não era tão elevado se comparado com os recursos despendidos em fases posteriores, nas quais o foco da substituição de importações estará em setores mais complexos. Por isso o crescimento da dívida externa brasileira será menor durante a ditadura militar. Também por conta destas características, a industrialização brasileira não sofrerá tanto com estas restrições internas e externas:

Do pós-guerra até o final dos anos 50, as restrições implícitas no padrão de financiamento da economia brasileira não chegaram a constituir obstáculo ao processo de desenvolvimento econômico, em virtude do volume de recursos de investimentos relativamente modesto então demandado pela economia brasileira, dada a fase de industrialização então em curso. A possibilidade de contar com substancial ampliação do afluxo de capital externo de risco, com aumentos gradativos de arrecadação tributária, acompanhados do financiamento inflacionário, foi suficiente para manter o dinamismo econômico. $^{114}$

\footnotetext{
${ }^{111}$ Swap é uma operação financeira na qual os investidores trocam de posição no que diz respeito ao risco e à rentabilidade da operação. Têm como objetivo a diminuição de riscos para empresas bancos e grandes instituições financeiras. São comuns em transações envolvendo cambio, juros e commodities.

112 PIRES, Julio Manuel. Uma visão histórica sobre o problema do padrão de financiamento da economia brasileira. Ensaios FEE, Porto Alegre, v. 25, n. 2, pp. 545-560, out. 2004, pp. 547-548.

${ }^{113}$ Ibidem, pp. 549-550.

${ }^{114}$ Ibidem, p. 557.
} 
Do ponto de vista das empresas privadas, estas contavam com duas fontes básicas de financiamento: o autofinanciamento e o acesso aos capitais do exterior. $\mathrm{O}$ autofinanciamento destas empresas está relacionado à estrutura do capital industrial do país. Como havia uma presença forte do capital externo, as filiais brasileiras tinham um acesso virtual a grandes volumes de capital de empréstimo.

A ação governamental (crédito, benefícios fiscais, tarifários) também contribuiu para estas empresas. As autoridades governamentais concederam, via de regra, os mais variados estímulos ao ingresso e à lucratividade dos capitais externos, como, por exemplo, a Instrução 113 da SUMOC, que permitiu a importação de máquinas e equipamentos sem cobertura cambial para o Brasil, na forma de investimento direto, e também os já citados swaps. Ou seja, a questão do financiamento para as empresas privadas foi resolvida com autonomia em relação ao sistema financeiro interno. ${ }^{115}$

As entidades do setor público (administração direta, autarquias, empresas estatais), por sua vez, praticavam, em regra, uma política de preços e tarifas que visava a subsidiar e impulsionar a atividade privada. Por conta disso, foram incapazes de se autofinanciar. Por isso, tinham a necessidade de recorrer ao apoio de fontes externas de financiamento. Com a criação do Banco Nacional de Desenvolvimento Econômico (BNDE), em 1952, as empresas públicas passaram a dispor de um importante instrumento de financiamento. De fato, entre os anos 50-60 coube ao BNDE o papel de principal provedor de créditos às estatais e autarquias. ${ }^{116}$

\subsubsection{Reformas dos governos militares}

Se a combinação entre o afluxo de capitais externos de risco, o financiamento inflacionário e o aumento da arrecadação tributária constituiu uma solução para o financiamento da industrialização brasileira até a década de 50, esta solução se revelou esgotada na década seguinte, levando o governo militar que tomou o poder em 1964, a partir de um golpe de Estado, a adotar um conjunto de reformas tanto no sistema financeiro quanto no tributário.

\footnotetext{
${ }^{115}$ CRUZ, Paulo R. Davidoff C. Notas sobre financiamento de longo prazo na economia brasileira do após guerra, 12/1994, Economia e Sociedade (UNICAMP. Impresso), Vol. S/N, Fac. 3, Campinas, 1994, pp. 67-69.

${ }^{116}$ Ibidem, pp. 70-71.
} 
Este esgotamento se deveu, sobretudo, à crise gerada após a implantação do Plano de Metas, durante o governo Juscelino Kubitschek, entre 1956 e 1960. O Plano de Metas é considerado por alguns como o auge do período da industrialização por substituição de importações $^{117}$, e consistiu em superar pontos de estrangulamento em setores da economia brasileira, especialmente na oferta de infraestrutura e de bens intermediários, além de criar pontos de germinação, através dos quais o investimento geraria demandas derivadas que iriam acarretar novos investimentos (demanda derivada). Tinha como objetivo central promover a montagem de uma estrutura industrial integrada, com o aprofundamento da produção de bens de consumo duráveis, especialmente a indústria automobilística. $^{118}$

O Plano foi bem sucedido no cumprimento das metas, entretanto, aprofundou as contradições do modelo industrial brasileiro, pois seu financiamento se deu, sobretudo, através de emissão monetária, o que causou uma aceleração inflacionária. Do ponto de vista externo, aumentou a dívida externa e o déficit de transações correntes. ${ }^{119}$

Assim sendo, com o objetivo de fazer frente a estas dificuldade, a ditadura militar implementou um conjunto de reformas já nos seus primeiros anos. O Plano de Ação Econômica do Governo (PAEG), lançado em 1964 com objetivos de estabilidade de preços e do setor externo, "definiu um novo padrão de financiamento para a economia em geral e para o Estado em particular". ${ }^{120}$ Este novo padrão foi lastreado em mecanismos destinados a captar recursos externos e internos de maneira nãoinflacionária.

No que diz respeito ao financiamento externo, a principal preocupação dos militares foi a inserção do país nos fluxos internacionais de capital, que estavam em franca expansão no período. Contribuiu para isso a mudança política causada pelo golpe, que permitiu que o ambiente se tornasse mais "confiável" aos investidores. Os militares realizaram uma reforma monetário-financeira, cujas principais medidas foram ${ }^{121}$ :

\footnotetext{
117 GREMAUD, Amaury Patrick; VASCONCELOS, Marco Antonio Sandoval; TONETO JUNIOR, Rudinei. Economia Brasileira contemporânea. $7^{\mathrm{a}}$ edição. $11^{\mathrm{a}}$ reimpressão. Editora Atlas. São Paulo, 2014 , p. 365

118 Ibidem, pp. 365-370.

119 Ibidem, pp. 371-374.

120 PIRES, Julio Manuel. Uma visão histórica sobre o problema do padrão de financiamento da economia brasileira. Ensaios FEE, Porto Alegre, v. 25, n. 2, p. 545-560, out. 2004, p. 551.

${ }^{121}$ GREMAUD; VASCONCELOS; TONETO JUNIROR, op. cit., pp. 380-381.
} 
i) Reforma da Lei 4.131/1962, facilitando o acesso do setor privado ao crédito fornecido por bancos estrangeiros;

ii) Criação da correção monetária e da emissão das ORTNs (Obrigações Reajustáveis do Tesouro Nacional), o que propiciou a superação da Lei da Usura e permitiu o desenvolvimento do mercado de títulos públicos, e;

iii) Edição da Resolução $n^{\circ} 63$ do Banco Central do Brasil, que facilitava a contratação de empréstimos externos pelos bancos nacionais com objetivo de repasse às empresas.

Assim, conforme demonstra Julio Manoel Pires ${ }^{122}$, como consequência de dois fatores, quais sejam, a maior liquidez internacional e a constituição de mecanismos institucionais voltados à captação de recursos externos, o período pós-64 permitiu "uma enorme ampliação do endividamento externo como instrumento da economia brasileira”. No período 1965-73: dívida externa passou de 3,6 bi para 12,5 bi (em dólares). Em 1979, valor chegaria a 49,9 bi.

Em relação à reforma tributária realizada pelos militares, houve um forte aumento da arrecadação, que ocorreu de forma concomitante à sua centralização no governo central. Ainda, houve a instituição de vários fundos parafiscais como o FGTS (Fundo de Garantia por Tempo de Serviço), e o PIS (Programa de Integração Social), que constituíram em importantes fontes de poupança compulsória.

Por outro lado, $\mathrm{Cruz}^{123}$ aponta que o BNDE deixou, progressivamente, de financiar o setor público e passou, cada vez mais, a destinar seus recursos ao setor privado. Até o golpe, $90 \%$ dos recursos liberados eram absorvidos pelo setor público. Durante o II PND, esse percentual chegou a 20\%. Para Gremaud, Vasconcelos e Toneto Junior ${ }^{124}$, isso acontece porque, com o novo quadro institucional desenhado pelos militares, os bancos de investimento privado deveriam atender ao crédito de médio e longo prazo, enquanto os bancos de desenvolvimento estatais deveriam financiar operações especiais de fomento através do repasse de recursos fiscais e recursos externos.

\footnotetext{
${ }^{122}$ PIRES, Julio Manuel. Uma visão histórica sobre o problema do padrão de financiamento da economia brasileira. Ensaios FEE, Porto Alegre, v. 25, n. 2, p. 545-560, out. 2004, pp. 551-552.

${ }^{123}$ CRUZ, Paulo R. Davidoff C. Notas sobre financiamento de longo prazo na economia brasileira do após guerra, 12/1994, Economia e Sociedade (UNICAMP. Impresso), Vol. S/N, Fac. 3, Campinas, 1994, pp. 70-71.

${ }^{124}$ GREMAUD, Amaury Patrick; VASCONCELOS, Marco Antonio Sandoval; TONETO JUNIOR, Rudinei. Economia Brasileira contemporânea. $7^{\mathrm{a}}$ edição. 11 $1^{\mathrm{a}}$ reimpressão. Editora Atlas. São Paulo, 2014, pp. 382-383.
} 
Para Cruz ${ }^{125}$, as reformas de 1965/67 foram decisivas para se transitar de um sistema pouco diferenciado - apoiado nos bancos comerciais e em algumas agências públicas de fomento - para um sistema mais complexo que se propunha a modernizar o financiamento das empresas e das famílias. No entanto, apesar de uma tentativa de dar protagonismo aos bancos de investimento privado e também ao mercado de capitais (Lei 4.728/1965 reformou o mercado de capitais, aproximando-o do modelo americano), o financiamento de longo prazo no país permaneceu como uma lacuna importante. As razões apontadas para isso variam desde a impossibilidade do desenvolvimento de ativos financeiros em economias inflacionárias até a recusa do capital bancário brasileiro a participar de atividades de maior risco. ${ }^{126}$

Para o autor ${ }^{127}$, as mudanças no capitalismo central, com o desenvolvimento do euromercado e a internacionalização das operações de crédito, bem como a manutenção de um padrão industrial com forte presença do capital externo, fez com que a criação de instituições de financiamento de longo prazo não fosse uma necessidade nesta época.

Assim, a ditadura militar institui, de fato, um padrão de financiamento baseado no financiamento externo que, ao lado do aumento da carga tributária, pode sustentar um período de fortíssimo crescimento econômico, mas que traria consequências deletérias à economia do país no período subsequente.

Sobre a adequação deste padrão de financiamento ao contexto internacional dos anos 60-70 e seu esgotamento no final desta década com a crise dos juros e os choques do petróleo, Pires é assertivo:

Grosso modo, podemos dizer que, até o final dos anos 70, esse padrão de financiamento pode operar de forma razoavelmente eficiente. Todavia a crise externa desencadeada a partir do segundo "choque do petróleo" e da elevação da taxa de juros norte-americana colocou obstáculos cada vez maiores à continuidade do financiamento externo; a moratória mexicana, em 1982, tornou tais obstáculos intransponíveis. O financiamento mediante a emissão de títulos da dívida pública interna viu-se cada vez mais problemático e custoso ao

\footnotetext{
${ }^{125}$ CRUZ, Paulo R. Davidoff C. Notas sobre financiamento de longo prazo na economia brasileira do após guerra, 12/1994, Economia e Sociedade (UNICAMP. Impresso), Vol. S/N, Fac. 3, Campinas, 1994, p. 65.

${ }^{126}$ Ibidem, p. 72.

${ }^{127}$ Ibidem, p. 73.
} 
longo dos anos 80 , tendo em vista a necessidade de redução do perfil da dívida em virtude das dificuldades de colocação junto ao público, ressabiado pelo volume ascendente do endividamento e pela possibilidade de inadimplência ou de redução do valor real dos seus créditos. $^{128}$

\subsubsection{Plano Nacional de Desenvolvimento}

Como vimos anteriormente, os choques do petróleo da década de 1970 foram importantes marcos do fim de uma ordem econômica internacional erigida no fim da segunda guerra mundial, que tinha como características a regulação dos fluxos de capitais e um padrão cambial fixo baseado na relação dólar-ouro.

Mais que isso, os choques marcaram o fim de um período estável e de muita prosperidade para as nações capitalistas. Durante a vigência das instituições criadas em Bretton Woods, houve uma forte interação entre o crescimento do produto (riqueza) e da produtividade, levando a um aumento simultâneo de lucros e salários que retroalimentava as fontes de dinamismo. Já na segunda metade da década de 1970, os indicadores econômicos revelavam a exaustão do dinamismo: há mundialmente uma desaceleração do crescimento, conjugada com uma perda de dinamismo do comércio internacional, bem como um aumento dos juros e da inflação ${ }^{129}$.

\begin{tabular}{|l|c|c|c|}
\hline \multicolumn{4}{|c|}{ Tabela 1 - Indicadores da Economia Mundial } \\
\hline Indicador & $1950-60$ & $1960-70$ & $1970-80$ \\
\hline PIB Total & 4,2 & 5,3 & 3,6 \\
\hline Taxas de Juros de Longo Prazo (Nominais) & 3,7 & 5,1 & 8,2 \\
\hline Índice de Preços (IPC) & 2,5 & 2,7 & 7,9 \\
\hline
\end{tabular}

Fonte: CARNEIRO, Ricardo. Desenvolvimento em Crise: a economia brasileira no último quarto do século XX. Editora Unesp, IE Unicamp. São Paulo, 2002, p. 48. Os dados sobre taxa de juros e inflação dizem respeito à média ponderada dos países: Estados Unidos, Reino Unido, Alemanha e França.

128 PIRES, Julio Manuel. Uma visão histórica sobre o problema do padrão de financiamento da economia brasileira. Ensaios FEE, Porto Alegre, v. 25, n. 2, p. 545-560, out. 2004, p. 552.

${ }^{129}$ CARNEIRO, Ricardo. Desenvolvimento em Crise: a economia brasileira no último quarto do século $X X$. Editora Unesp, IE Unicamp. São Paulo, 2002, pp. 48-49. 
No Brasil, vivia-se o final do "milagre econômico", intervalo de tempo no qual, sob um regime ditatorial, o país cresceu a taxas elevadas, tendo como base principal de financiamento o endividamento externo. Os países da periferia do capitalismo, especialmente aqueles não-produtores de petróleo sofreram bastante com o impacto do aumento do preço dessa matéria prima.

O Brasil, no entanto, respondeu de maneira peculiar a estas mudanças na ordem econômica internacional, através do II Plano Nacional de Desenvolvimento (II PND), lançado pelo presidente Ernesto Geisel em 1974. O período de forte crescimento do "milagre econômico" já dava sinais de esgotamento, como a aceleração inflacionária e dependia de condições externas favoráveis para a manutenção do ciclo expansionista. Entretanto, o cenário global era o oposto, dada a crise internacional desencadeada pelo primeiro choque do petróleo no ano anterior (1973). O governo militar decide, então, lançar um novo ciclo de forte investimento na economia, tentando completar mais uma fase da industrialização brasileira, com foco especialmente na indústria pesada, promovendo um ajuste estrutural na economia e diminuindo a dependência brasileira de matérias-primas importadas. Para Ricardo Carneiro o II PND compreendia:

(...) um amplo programa de investimentos, cujo objetivo último era permitir a correção dos desequilíbrios na estrutura industrial e no setor externo, típicos de uma situação de subdesenvolvimento, ainda presentes na economia brasileira apesar de quase meio século de crescimento industrial contínuo. ${ }^{130}$

Ricardo Carneiro, prosseguindo na sua explanação, aponta que a estratégia do II PND pode ser sintetizada em 4 eixos: i) Modificações na matriz industrial, ampliando a participação da indústria pesada; ii) Mudanças na organização industrial, acentuando participação da empresa privada nacional; iii) Desconcentração regional; iv) Melhoria na distribuição de renda.

A lógica do modelo, para Gremaud, Vasconcelos e Toneto Junior era a seguinte: as estatais avançariam com seus investimentos no setor de insumos básicos e, a partir disso, gerariam uma enorme demanda derivada que, por sua vez, estimularia o setor privado a investir em bens de capital. O II PND tinha como meta alcançar um

\footnotetext{
${ }^{130}$ CARNEIRO, Ricardo. Desenvolvimento em Crise: a economia brasileira no último quarto do século
} $X X$. Editora Unesp, IE Unicamp. São Paulo, 2002, pp. 59-60. 
crescimento anual de $10 \%$ do PIB, com crescimento industrial em torno de $12 \%$. Estas taxas não foram alcançadas, entretanto, o período de 1974-79 registrou elevadas taxas de crescimento econômico ${ }^{131}$.

A política anticíclica da época, bem como a atuação do Estado, não se ativeram aos gastos em infraestrutura. Após 1976, o Estado apoia de forma mais incisiva a uma política de sustentação de setores prioritários, como energia, agricultura e o setor exportador, por meio de linhas de crédito subsidiadas, isenções e subsídios diretos ${ }^{132}$. Isto pode ser comprovado por meio da tabela abaixo, que mostra uma situação estável na carga tributária bruta, enquanto a carga tributária líquida declinava.

\begin{tabular}{|l|c|c|c|c|c|c|c|}
\hline \multicolumn{7}{|c|}{ Tabela 2 - Carga Tributária Bruta e Líquida (em \% do PIB) } \\
\hline ANO & 1974 & 1975 & 1976 & 1977 & 1978 & 1979 & 1980 \\
\hline CARGA TRIBUTÁRIA BRUTA & 25,1 & 25,2 & 25,1 & 25,5 & 25,7 & 24,7 & 24,7 \\
\hline TRANSFERÊNCIAS & 8,8 & 10,1 & 9,4 & 9,4 & 10,7 & 10,6 & 12,6 \\
\hline CARGA TRIBUTÁRIA LÍQUIDA & 16,3 & 15,2 & 15,7 & 16,2 & 15,0 & 14,1 & 12,1 \\
\hline
\end{tabular}

Fonte: CARNEIRO, Ricardo. Desenvolvimento em Crise: a economia brasileira no último quarto do século XX. Editora Unesp, IE Unicamp. São Paulo, 2002, p. 101. No campo "transferências" estão computados os juros da dívida (interna e externa), assistência e previdência e subsídios.

O Estado atuava, ainda, através dos fundos de poupança compulsória, bem como por meio das instituições especiais de crédito. Além disso, o BNDE cumpriu o importante papel de financiar o setor privado para expansão do setor de bens de capital. Vale ressaltar que, os empréstimos desta instituição eram realizados com uma correção monetária pré-fixada, causando um desequilíbrio patrimonial ao banco, que era coberto por aportes do Tesouro Nacional. ${ }^{133}$

131 GREMAUD, Amaury Patrick; VASCONCELOS, Marco Antonio Sandoval; TONETO JUNIOR, Rudinei. Economia Brasileira contemporânea. $7^{\mathrm{a}}$ edição. $11^{\mathrm{a}}$ reimpressão. Editora Atlas. São Paulo, 2014, pp. 402-403.

${ }^{132}$ CARNEIRO, Ricardo. Desenvolvimento em Crise: a economia brasileira no último quarto do século XX. Editora Unesp, IE Unicamp. São Paulo, 2002, p. 101.

${ }^{133}$ Ibidem, p. 97. 
Todavia, apesar de se propor a realizar um ajuste estrutural na economia brasileira, o II PND não alterou substancialmente o modelo histórico de desenvolvimento, nem o padrão de financiamento consolidado na primeira década da ditadura militar. No que diz respeito ao padrão de desenvolvimento, o que o Plano buscava era diferenciar a estrutura produtiva, aproximando-a daquela existente nos países centrais, a fim de resolver o problema do atraso nos setores pesados. ${ }^{134}$ No que concerne ao financiamento das atividades produtivas, o II PND não realizou nenhuma reforma que visasse à superação do modelo herdado do período do milagre, pelo contrário:

Os obstáculos ao crescimento, em nenhum momento, eram percebidos como resultado da inadequação da base financeira doméstica, assentada na poupança compulsória e largamente dependente de financiamentos externos. Em consonância com a tese da continuidade ante o período anterior e, sobretudo, no que diz respeito ao arcabouço de financiamento, o II PND não previa mudanças significativas nesse campo. $^{135}$

Ou seja, durante o II PND houve um aprofundamento do endividamento externo brasileiro, como mostram os números abaixo:

\begin{tabular}{|c|c|c|c|c|c|}
\hline \multicolumn{5}{|c|}{ Tabela 3 - Dívida Externa Brasileira (em US\$ milhões) } \\
\hline 1974 & 1975 & 1976 & 1977 & 1978 & 1979 \\
\hline 17.165 & 21.171 & 25.985 & 32.037 & 43.510 & 49.904 \\
\hline
\end{tabular}

Fonte: GREMAUD, Amaury Patrick; VASCONCELOS, Marco Antonio Sandoval; TONETO JUNIOR, Rudinei. Economia Brasileira contemporânea. $7^{\mathrm{a}}$ edição. $11^{\mathrm{a}}$ reimpressão. Editora Atlas. São Paulo, 2014, p. 400.

Razão importante para a continuidade da aposta no endividamento externo repousa na facilidade que havia em obter recursos no exterior por conta do processo de reciclagem dos petrodólares. Inundados de dólares oriundos das altas no petróleo, os países da

\footnotetext{
${ }^{134}$ CARNEIRO, Ricardo. Desenvolvimento em Crise: a economia brasileira no último quarto do século $X X$. Editora Unesp, IE Unicamp. São Paulo, 2002, p. 63.

${ }^{135}$ Ibidem, p. 64.
} 
OPEP, diante da impossibilidade de reinvestirem esse dinheiro em suas economias domésticas, injetavam-no no sistema financeiro internacional. ${ }^{136}$ Para Ricardo Carneiro, entretanto, a atrofia do sistema financeiro privado interno, que permaneceu durante o período do II $\mathrm{PND}^{137}$ foi o fator determinante.

Não houve apenas um aumento quantitativo da dívida externa brasileira. Houve também uma mudança do perfil desta dívida, que se tornou majoritariamente pública. Em outras palavras, ocorre, durante o II PND, uma estatização da dívida externa brasileira. Em 74, era 50\% a participação do setor público na dívida externa, percentual que chegou a $69 \%$ em $1980 .^{138}$

Uma causa que pode ser apontada é a forte presença do Estado nos investimentos do período. No II PND, estatais eram os carros-chefes dos investimentos. Contudo, suas políticas de preços e tarifas foram novamente utilizadas como subsídio ao setor privado, o que minou sua capacidade de autofinanciamento e levou à solução do endividamento externo. Durante o Plano de Metas, esta política tarifária também se fez presente. Mas, enquanto nos anos 50 os empréstimos eram contraídos principalmente a partir de agências públicas, no II PND as fontes de recursos eram bancos privados internacionais. $^{139}$

Ricardo Carneiro aponta que, em momentos de maiores flutuações do ciclo doméstico e de maior dificuldade no balanço de pagamentos, como foram os anos pós-74, o investimento privado tende a se retrair ainda mais, com as captações públicas aumentando proporcionalmente em conjunturas externas adversas (aumento dos juros, por exemplo) $^{140}$.

O autor observa, ainda, que havia três possibilidades de o Estado brasileiro financiar estes investimentos de larga escala. A primeira delas seria o autofinanciamento que, como vimos anteriormente, seria impossível devido à utilização das políticas tarifárias

\footnotetext{
136 GREMAUD, Amaury Patrick; VASCONCELOS, Marco Antonio Sandoval; TONETO JUNIOR, Rudinei. Economia Brasileira contemporânea. $7^{\mathrm{a}}$ edição. $11^{\mathrm{a}}$ reimpressão. Editora Atlas. São Paulo, 2014 , p. 404.

${ }^{137}$ CARNEIRO, Ricardo. Desenvolvimento em Crise: a economia brasileira no último quarto do século XX. Editora Unesp, IE Unicamp. São Paulo, 2002, p. 87.

${ }^{138}$ Ibidem, pp. 93-94.

${ }^{139}$ CRUZ, Paulo R. Davidoff C. Notas sobre financiamento de longo prazo na economia brasileira do após guerra, 12/1994, Economia e Sociedade (UNICAMP. Impresso), Vol. S/N, Fac. 3, Campinas, 1994, pp. 70-72.

${ }^{140}$ CARNEIRO, op. cit., p. 95.
} 
como subsídios ao setor privado. Ademais, a contenção dos preços públicos servia ainda aos propósitos anti-inflacionários do regime militar. A segunda possibilidade era o aporte de recursos fiscais. Todavia, isto implicaria na realização de uma reforma tributária que ampliasse a arrecadação do Estado. Sobrou, então, a terceira alternativa, que era a do financiamento externo, facilitada, como vimos, pela abundância de crédito internacionalmente. ${ }^{141}$

Assim, pode-se dizer que o II PND, lançado em um contexto de choques do petróleo, elevação das taxas de juros e elevada liquidez internacional, alcança o objetivo de avançar mais uma etapa na industrialização brasileira, com foco na indústria pesada. Entretanto, ao aprofundar o padrão de financiamento através do endividamento externo, deixa como legado um aumento da dívida externa, em volume e também no seu grau de estatização, o que conduziria o país a uma crise significativa na década seguinte.

\subsubsection{A década de 1980 e a crise da dívida}

Os anos 1980 ficaram conhecidos como a "década perdida" para a economia brasileira. Após um período de aproximadamente 50 anos de crescimento econômico, o país sofre com uma grave crise que o leva à recessão e à escalada da inflação, no começo da década. Segundo Fiori ${ }^{142}$, houve durante estes 10 anos: oito planos de estabilização da moeda, quatro diferentes moedas nacionais, onze índices de inflação, cinco congelamentos de preços e salários, além de dezenas de alterações nas regras de câmbio, controle de preços e propostas de renegociação da dívida externa. Como veremos a seguir, mais que um momento conjuntural de crise, a década de 1980 representou, sobretudo, uma ruptura definitiva com o padrão de financiamento que a economia brasileira construiu no período desenvolvimentista, especialmente nos anos da ditadura militar.

Ocorre que, durante os anos 1980, adveio uma deterioração global da situação econômica dos países da periferia capitalista. O Banco Central americano passa a adotar em 1979 uma política monetária restritiva, na tentativa de conter a desvalorização do dólar que era verificada desde a adoção do cambio flutuante em 1973. Para isso,

\footnotetext{
${ }^{141}$ CARNEIRO, Ricardo. Desenvolvimento em Crise: a economia brasileira no último quarto do século XX. Editora Unesp, IE Unicamp. São Paulo, 2002, pp. 95-96.

${ }^{142}$ FIORI, José Luís. O nó cego do desenvolvimentismo brasileiro. In Novos Estudos CEBRAP no 40 , novembro de 1994, p. 142.
} 
restringiu o crédito e elevou drasticamente as taxas de juros ${ }^{143}$, o que provocou uma piora relativa nos termos de troca para os países periféricos. Além disso, o choque dos juros aumentou exponencialmente o peso do pagamento da dívida externa desses países. Em paralelo, houve um racionamento do financiamento externo: entre 1975-79, os países subdesenvolvidos eram o destino de $50 \%$ dos fluxos de capital, número que cai para $23 \%$ no período de $1985-89 .{ }^{144}$

O Brasil não fica imune a estes movimentos, que provocam um desequilíbrio em sua balança comercial. O choque dos juros com a elevação do peso do serviço da dívida provoca uma interrupção na absorção de recursos externos. Os empréstimos tomados pelo país passam a ser insuficientes para cobrir o serviço da dívida, levando a uma queima rápida de reservas. Este problema é acentuado em 1982, com a moratória mexicana que interrompe de vez os fluxos de capital. Se entre 1979-82 ainda havia alguma absorção de recursos externos, mesmo que insuficiente, a partir daí vai haver uma forte transferência de recursos para o exterior para o pagamento da dívida externa. $^{145}$

O governo brasileiro passa a adotar uma política recessiva para conter a demanda interna, e de estímulo às exportações para corrigir os desequilíbrios na balança comercial e fazer frente à necessidade de pagamento da dívida externa. Assim, o país teve PIB negativo em 1981 e 1983, e baixo crescimento em 1982. No tocante à balança comercial, o ajuste promovido alcançou seus objetivos, pois a política recessiva levou a uma queda nas importações, e o país obteve superávits comerciais em 1983 e 1984. Entretanto, os incentivos às exportações contribuíram para uma piora na situação fiscal do país. ${ }^{146}$

A interrupção do fluxo de capitais externos para o país teve, todavia, efeitos diferenciados, como aponta Cruz. ${ }^{147}$ As empresas de capital estrangeiro, antecipando-se às turbulências, reduziram as tomadas de empréstimo já no fim dos anos 1970 e

\footnotetext{
${ }^{143}$ GREMAUD, Amaury Patrick; VASCONCELOS, Marco Antonio Sandoval; TONETO JUNIOR, Rudinei. Economia Brasileira contemporânea. $7^{\mathrm{a}}$ edição. 11 $1^{\mathrm{a}}$ reimpressão. Editora Atlas. São Paulo, 2014, pp. 408-409.

${ }^{144}$ CARNEIRO, Ricardo. Desenvolvimento em Crise: a economia brasileira no último quarto do século XX. Editora Unesp, IE Unicamp. São Paulo, 2002, pp. 115-119.

${ }^{145}$ Ibidem, pp. 116-123.

${ }^{146}$ GREMAUD; VASCONCELOS; TONETO JUNIROR, op. cit., pp. 110-112.

${ }^{147}$ CRUZ, Paulo R. Davidoff C. Notas sobre financiamento de longo prazo na economia brasileira do após guerra, 12/1994, Economia e Sociedade (UNICAMP. Impresso), Vol. S/N, Fac. 3, Campinas, 1994, pp. 74-76.
} 
consequentemente amenizaram o impacto da crise sobre as suas atividades. Durante os anos 1980, continuou caindo o volume de investimentos diretos estrangeiros. Assim, filiais de empresas no exterior reduziram a mobilização de recursos externos e repatriaram parcela cada vez maior dos lucros. Já o setor público foi ainda mais impactado. As autoridades monetárias nacionais haviam assumido parcela substantiva dos compromissos em moeda estrangeira do setor privado. As empresas estatais, que tinham grande passivo em moeda estrangeira, também viram crescer suas despesas financeiras pela elevação da taxa internacional de juro e pela política cambial ao mesmo tempo em que viram reduzir drasticamente seu acesso a recursos no exterior. A capacidade de investimento destas empresas ficava, assim, completamente deteriorada. A título de comparação, os investimentos das estatais representavam 7\% do PIB entre 1975-79, reduzindo-se a 2,7\% no período 1986-90.

Pires ${ }^{148}$ traça um paralelo entre a crise dos anos 1960, posterior ao Plano de Metas do Governo JK, e a crise dos anos 1980. Para ele, ambas as crises acontecem após momentos em que se promoveu estruturas profundas no aparato produtivo, com novos patamares alcançados no processo de industrialização. Entretanto, o autor aponta algumas diferenças: i) houve uma maior aceleração inflacionária nos anos 1970, por conta da indexação criada com a correção monetária; ii) o nível de endividamento externo do país era muito maior nos governos Geisel e Figueiredo, em termos relativos e absolutos do PIB; iii) a possibilidade de contrair empréstimos externos era menor na década de 1980, e; iv) mudanças na relação Estado-sociedade, uma vez que, com a institucionalização de um regime autoritário na segunda metade dos anos 1960, foi mais fácil encontrar saídas institucionais para retomada do crescimento.

Quanto a este último ponto, considerado por Cruz como a diferença mais importante entre as duas crises, Fiori ${ }^{149}$ aponta que a falência fiscal do Estado nos anos 1980 aguçou as contradições políticas do regime militar, rompendo a aliança entre o empresariado nacional e a ditadura, ao mesmo tempo em que crescia a contestação dos trabalhadores à regulação do mundo do trabalho estabelecida pelo regime autoritário. Neste cenário:

\footnotetext{
148 PIRES, Julio Manuel. Uma visão histórica sobre o problema do padrão de financiamento da economia brasileira. Ensaios FEE, Porto Alegre, v. 25, n. 2, p. 545-560, out. 2004, pp. 554-555.

${ }^{149}$ FIORI, José Luís. O nó cego do desenvolvimentismo brasileiro. In Novos Estudos CEBRAP $\mathrm{n}^{\circ} 40$, novembro de 1994, pp.137-142.
} 
(...) as manifestações críticas se acumularam em velocidade crescente, e a perda de poder do Estado passou a refletir-se de forma mais manifesta na sinuosidade e impotência de sua política econômica, frente ao avanço acelerado do processo inflacionário e a permanência da estagnação econômica. ${ }^{150}$

Os acontecimentos que se seguiram no campo político são de conhecimento público: a ditadura entra em seu outono e é substituída por um novo regime democrático estabelecido pela Constituição Federal de 1988. Entretanto, a década de 1980 deixa consequências profundas no campo econômico, que ainda perduram, especialmente no que diz respeito à busca de novas formas de financiamento para o desenvolvimento brasileiro, dado a quebra do padrão que se constituiu anteriormente e a perda da capacidade fiscal do Estado e de suas empresas, causada pelo aumento e pela estatização do endividamento brasileiro.

${ }^{150}$ FIORI, José Luís. O nó cego do desenvolvimentismo brasileiro. In Novos Estudos CEBRAP no 40, novembro de 1994, p. 142. 


\section{REGULAÇÃO DAS ENTIDADES FECHADAS DE PREVIDÊNCIA COMPLEMENTAR}

Neste capítulo, iremos nos debruçar sobre a legislação e as instituições que fazem regulação da Seguridade Social no Brasil e em especial das Entidades Fechadas de Previdência Complementar (EFPC), desde sua previsão constitucional às normas emanadas pelos agentes reguladores. As normas serão analisadas sob o ponto de vista do seu conteúdo dogmático, sendo o seu estudo subsidiado pelos conceitos trazidos do Direito Administrativo e do Direito Econômico. A análise também levará em conta a dimensão histórica e econômica, contextualizando as mudanças na estrutura da Previdência Social.

O principal objetivo deste capítulo é compreender a forma como está estruturada em nosso país a seguridade social, e quais são os espaços abertos pela opção política dos constituintes e legisladores para a atuação do Estado por meio da Previdência Complementar em geral e, especificamente, das EFPC.

Atualmente, a seguridade social é prevista na Constituição Federal no seu Título VII, artigo 194. A Constituição estabelece que a seguridade social é composta pelo tripé saúde, assistência social, e previdência social.

A previdência, por sua vez, é formada atualmente por dois núcleos fundantes ${ }^{151}$ : o núcleo básico, de natureza estatal e pública, e o complementar, de caráter privado, que constitui uma proteção social adicional, supervisionada pelo governo federal e com relações jurídicas submetidas às normas de direito privado. Veremos que esta estruturação guarda alguma semelhança com modelos disseminados nos países ocidentais, combinando formas de gestão estatal - geralmente vinculadas a regimes de repartição $^{152}$ - e de gestão privada - estas em regra vinculadas a regimes de capitalização.

A previdência complementar, núcleo dentro do qual se situa o objeto de estudo no presente trabalho, tem as características da facultatividade, da subsidiariedade e da

\footnotetext{
${ }^{151}$ JARDIM, Maria A. Chaves. Entre a solidariedade e o risco: sindicatos e fundos de pensão em tempos de governo Lula. São Paulo: Annablume, Fapesp, 2009, p. 14.

${ }^{152}$ Ver no capítulo 1 do presente trabalho as definições dos regimes de repartição e capitalização.
} 
solidariedade, conforme explica Anna Luiza Duarte. ${ }^{153}$ A facultatividade se expressa através da forma de admissão do segurado no sistema de proteção. É facultado ao trabalhador a adesão ou não a determinado plano de benefícios. A subsidiariedade se explica pelo caráter complementar deste núcleo de previdência, enquanto a solidariedade se explica pelo fato de os recursos aplicados não serem suficientes para o pagamento das aposentadorias. Recorre-se, assim, a uma solidariedade entre os participantes. $^{154}$

O núcleo básico, de caráter público, se divide entre o Regime Geral de Previdência Social, de caráter contributivo e filiação obrigatória (Constituição Federal, art. 201), e os Regimes Próprios de Previdência Social dos servidores públicos (Constituição Federal, art. 40), também de caráter contributivo.

No núcleo complementar de previdência, por sua vez, temos dois grandes tipos de entidades. O primeiro deles é o de Entidades Abertas de Previdência Complementar (EAPC), constituídas sob a forma de sociedades anônimas e acessíveis a quaisquer pessoas físicas, tendo como objetivo instituir e operar planos de benefícios de caráter previdenciário concedidos de forma continuada ou de pagamento único.

De outro lado, temos as Entidades Fechadas de Previdência Complementar (EFPC), mais conhecidas como fundos de pensão. As EFPC são constituídas sob a forma de fundações ou sociedade civil sem fins lucrativos ${ }^{155}$, e têm seus planos endereçados a um público específico, ou melhor, aos empregados de uma determinada empresa, grupo de empresas ou aos associados de entidade de classe ou de representação.

Assim, compomos o quadro geral da previdência social no Brasil:

\footnotetext{
${ }^{153}$ DUARTE, Anna Luiza. A gestão dos fundos de pensão e a sua influencia sobre a organização interna das empresas participadas. Dissertação de Mestrado apresentada à Faculdade de Direito da Universidade de São Paulo, 2003, pp. 14-16.

${ }^{154} \mathrm{~A}$ presença da característica solidariedade na previdência complementar, defendida por Duarte, é questionada por Maria Luiza Jardim, para quem neste modelo está presente a ideia de auto empreendedorismo e de individualismo, uma vez que a capitalização favorece o aparecimento do "individualismo patrimonial". Ver JARDIM, Maria A. Chaves. Entre a solidariedade e o risco: sindicatos e fundos de pensão em tempos de governo Lula. São Paulo: Annablume, Fapesp, 2009, pp. 3435.

${ }^{155}$ Exceto o Funpresp, fundo de pensão dos servidores públicos titulares de cargos efetivos na União, que, conforme veremos posteriormente, foi constituído sob a forma de autarquia, conforme previsão do art. 40 da Constituição Federal e art. $4^{\circ}, \S^{\circ}$ da Lei 12.618/2012.
} 


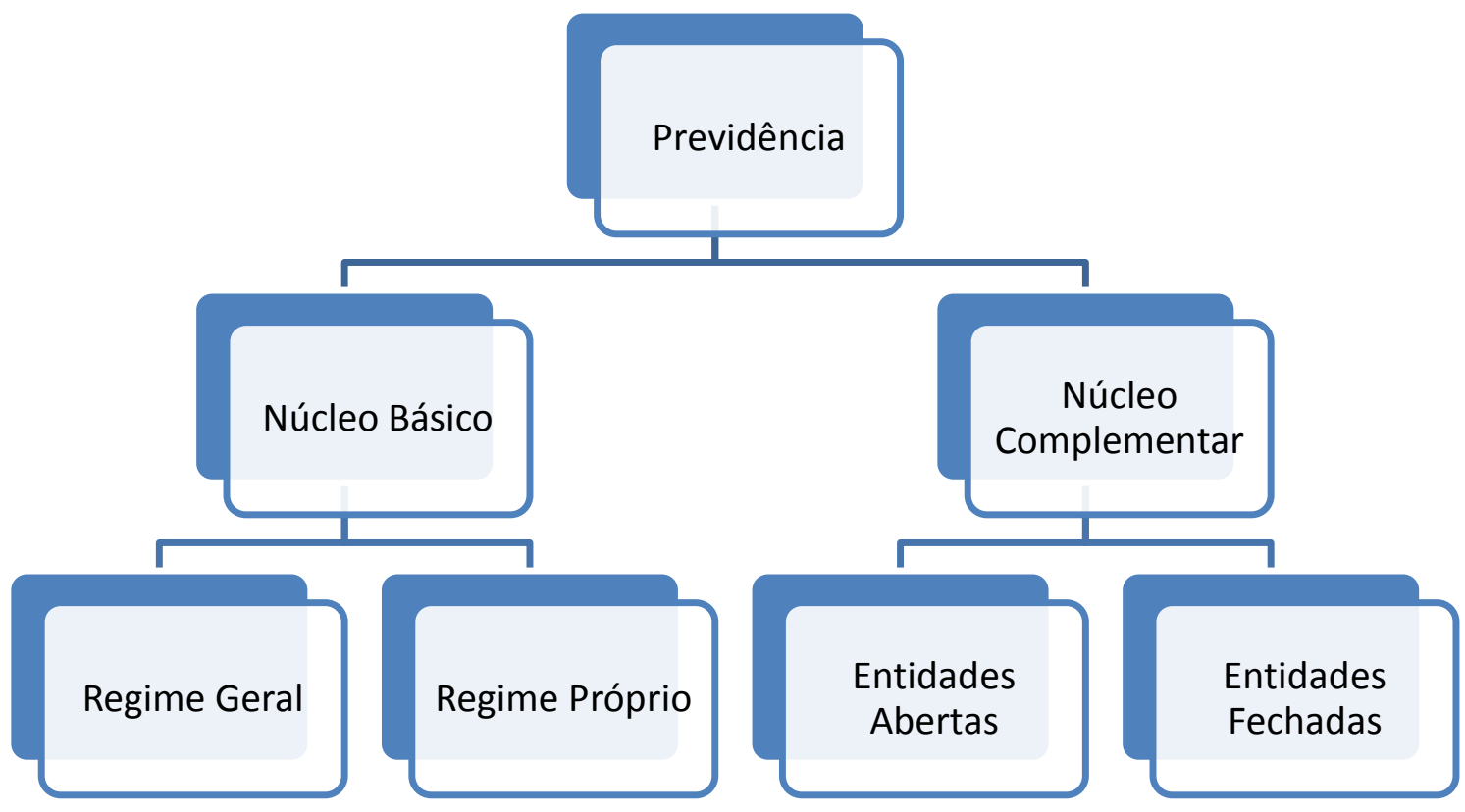

Fonte: Elaboração própria.

As Entidades Fechadas de Previdência Complementar patrocinadas pelas empresas estatais brasileiras, núcleo do nosso objeto de estudo, submetem-se à disciplina da Lei Complementar 109/2001, que diz respeito à Previdência Complementar como um todo, mas também à Lei Complementar 108/2001, que dispõe sobre a relação entre os entes públicos (incluindo, aqui, as empresas controladas pelo Estado) e suas EFPC.

Sua atuação se dá sob a supervisão e fiscalização da Superintendência Nacional de Previdência Complementar (Previc), autarquia vinculada ao Ministério da Previdência Social. O órgão regulador, por sua vez, é o Conselho Nacional de Previdência Complementar, vinculado a este mesmo Ministério. No que diz respeito à estrutura interna, as entidades patrocinadas pelo poder público e suas empresas têm seus órgãos e competências delimitados pelo conteúdo da Lei Complementar 108/2001. Já a competência para disciplinar os seus investimentos é do Conselho Monetário Nacional $(\mathrm{CMN})$. Vejamos em mais detalhes sua estrutura e forma de atuação.

\subsection{Atuação do Estado no domínio econômico}

Precede à análise do conjunto de normas que dão forma às Entidades Fechadas de Previdência Complementar uma breve retomada da literatura do direito econômico e da Ordem Econômica na Constituição de 1988, para uma correta compreensão das formas de atuação do Estado no domínio econômico. Afinal, é o Direito Econômico que vai 
instrumentalizar a atuação do Estado, através do oferecimento de um leque de alternativas e arranjos institucionais, como a formação de empresas públicas, sociedades de economia mista, órgãos supervisores e reguladores, além da atividade de defesa da concorrência. Na Constituição estão inseridas as normas que devem conformar a atuação do Estado e dos agentes públicos, que deverão agir sempre no sentido da consecução de princípios e objetivos também nela elencados.

\subsubsection{A Ordem Econômica na Constituição de 1988}

A ideia de Ordem Econômica na Constituição pressupõe, logicamente, a possibilidade de distinção, dentre as normas constitucionais, aquelas que possuem ou não caráter econômico. Entretanto, esta possibilidade é discutível, vez que não há como precisar o que é, exatamente, a matéria econômica. Por isso, a doutrina alemã do pós-Primeira Guerra Mundial elaborou o conceito de constituição econômica, em oposição à concepção tradicional de constituição. ${ }^{156}$ Essa é a concepção que vai ser utilizada pelos autores aqui estudados, que enxergam a constituição econômica como parte integrante, não autônoma ou estanque, da constituição total. ${ }^{157}$

Gilberto Bercovici mostra que a constituição econômica não é uma inovação do século $\mathrm{XX}$, mas que mesmo as Constituições liberais já traziam em seu bojo as garantias do sistema econômico liberal, como a propriedade, as liberdades contratual e de comércio. $\mathrm{O}$ que vai diferenciar as constituições liberais daquelas do século XX é que, enquanto as primeiras se limitavam a sancionar o existente, as últimas, além de trazerem um capítulo sobre a ordem econômica de maneira sistematizada e formal, vão também propor transformações à realidade. ${ }^{158}$

Desta forma, a noção de constituição econômica vai estar intimamente ligada à de constituição dirigente, que defende a mudança da realidade pelo direito, buscando direcionar a atuação politica:

A Constituição dirigente busca racionalizar a política, incorporando uma dimensão materialmente legitimadora ao estabelecer um fundamento constitucional para a política. O núcleo da ideia de Constituição Dirigente é a proposta de legitimação material da

\footnotetext{
${ }^{156}$ COMPARATO, Fábio Konder. “Ordem Econômica na Constituição Brasileira de 1988”, Revista de Direito Público no 93, São Paulo, RT, janeiro/março de 1990, p. 263.

157 BERCOVICI, Gilberto. Constituição Econômica e Desenvolvimento: uma leitura a partir da constituição de 1988. Malheiros Editores. São Paulo, 2005, p. 13.

158 Ibidem, pp. 31-33.
} 
constituição pelos fins e tarefas previstos no texto constitucional para a política. $^{159}$

Promulgada no contexto da redemocratização brasileira, a Constituição de 1988 inserese no bojo das constituições dirigentes, contendo, no seu artigo $3^{\circ}$, o que se chama de cláusula transformadora. ${ }^{160}$ São os objetivos previstos neste artigo que devem conformar a atuação política dos agentes públicos tanto na elaboração legislativa quanto na implementação e execução de políticas públicas.

Pode-se afirmar que a Constituição de 1988 faz uma clara opção pelo sistema capitalista. Entretanto, não faz o mesmo em relação ao modelo liberal e à autorregulação da economia. Pelo contrário, estabelece um modelo econômico aberto, suscetível a ser ajustado às demandas sociais. Mais que isso, vai atribuir legitimidade à sociedade para reivindicar, perante o Estado, a execução de políticas públicas. ${ }^{161}$ Eros Grau fala em uma opção pelo modelo de bem-estar, no qual o Estado exercerá um papel decisivo:

$\mathrm{CF} / 88$ projeta um Estado desenvolto e forte, o quão necessário seja para que os fundamentos afirmados no seu $\operatorname{art}^{\circ} 1^{\mathrm{e}}$ os objetivos definidos no art. $3^{\circ}$ venham a ser plenamente realizados garantindo-se tenha por fim, a ordem econômica, assegurar a todos existência digna. $^{162}$

Além dos fundamentos e objetivos enunciados no Título I da constituição, o Título VII, que trata da Ordem Econômica e Financeira traz, no art. 170, os princípios da ordem econômica. Estes princípios são os que deverão nortear a ação dos agentes econômicos privados, bem como a organização do mercado. ${ }^{163}$

No que diz respeito à divisão de competências em matéria econômica, pode-se dizer que a Constituição de 1988 dá preeminência à União, apesar de ter ensaiado uma divisão menos rígida entre esta e os outros entes federados. É a União que vai ditar a política

159 BERCOVICI, Gilberto. Constituição Econômica e Desenvolvimento: uma leitura a partir da constituição de 1988. Malheiros Editores. São Paulo, 2005, p. 35

${ }^{160}$ Ibidem, pp. 36-37.

${ }^{161}$ Ibidem, p. 31; e do mesmo autor BERCOVICI, Gilberto. Petróleo, Recursos Minerais e Apropriação do Excedente. Tese de titularidade apresentada à Faculdade de Direito da USP. São Paulo, 2010, pp. 234235; ver ainda, GRAU, Eros Roberto, A Ordem Econômica na Constituição de 1988 (Interpretação e Crítica), 12a ed., São Paulo, Malheiros, 2007, p. 352.

162 GRAU, op. cit. p. 131.

163 BERCOVICI, Gilberto. Petróleo, Recursos Minerais e Apropriação do Excedente, op. cit., pp. 234235. 
monetária e financeira, além de elaborar e executar planos nacionais e regionais de desenvolvimento econômico e social. $\mathrm{O}$ rol de competências administrativas e legislativas que são privativas da União é extenso e encontra-se nos artigos 21 e 22 , respectivamente. Dentre estas competências, destacamos algumas que são importantes para o presente trabalho:

Art. 21. Compete à União:

(...)

VIII - administrar as reservas cambiais do País e fiscalizar as operações de natureza financeira, especialmente as de crédito, câmbio e capitalização, bem como as de seguros e de previdência privada; (grifo nosso)

Art. 22. Compete privativamente à União legislar sobre:

(...)

XIX - sistemas de poupança, captação e garantia da poupança popular;

$(\ldots)$

XXIII - seguridade social;

\subsubsection{Direito Econômico: desenvolvimento histórico e conceito}

Em boa parte das análises econômicas mais correntes, de viés liberal, o mercado é apresentado como uma instituição espontânea, própria da natureza humana, isto é, como forma de produção e circulação de riquezas que prescinde de qualquer outro instrumento forjado pela sociedade para a sua manutenção e desenvolvimento.

Entretanto, como vimos no capítulo anterior desta dissertação, o mercado enquanto instituição autorregulável que detém a primazia na organização social é uma novidade histórica que aparece apenas no século XIX, sendo confrontado com mecanismos de autoproteção e organização da sociedade que acabam por transformá-lo estruturalmente. Enxergar o mercado e o modo de produção capitalista de forma natural e espontânea é fazer uma análise desprovida de historicidade, como assevera Gilberto Bercovici:

O mercado não é uma "ordem espontânea", natural, embora o discurso liberal sustente essa visão, mas é uma estrutura social, fruto da história 
e de decisões políticas e jurídicas que servem a determinados interesses, em detrimento de outros. ${ }^{164}$

Como tal, o mercado busca a sua sustentação em elementos outros que dizem respeito não só à esfera econômica, como no Estado, com a sua legitimação política, e no próprio direito, que vai, através da criação de institutos como a propriedade, o contrato, e a igualdade jurídica, fornecer os elementos necessários para a circulação de mercadorias.

O direito do modo de produção capitalista é racional e formal, caracterizando-se pela universalidade abstrata das formas jurídicas e pela igualdade formal perante a lei, refletindo a universalidade da troca mercantil e buscando garantir a previsão e a calculabilidade de comportamentos. ${ }^{165}$

Num primeiro momento do capitalismo, a ordem jurídica cumpre as funções de assegurar a livre circulação de mercadorias e de resguardar as "liberdades individuais", em contraposição a um poder autocrático centralizado, típico do modelo absolutista. Contudo, no início do século XX, com as necessidades impostas pelo esforço de guerra e pela crise econômica mundial, o liberalismo entrará em declínio e surgirá com mais força a discussão sobre o Direito Econômico propriamente dito.

Com as transformações do século XX, a ordenação da atividade econômica pelo Estado não vai mais se limitar à imposição do cumprimento de contratos, havendo uma demanda pela organização dos agentes econômicos destinada à produção em massa para as guerras e à superação da recessão.

Este "novo" direito vai assumindo importância cada vez maior para o modo de produção capitalista. Dada a sua natureza extravagante aos códigos e ao fato de sua atuação desafiar as categorias tradicionais da ciência jurídica, surgirão questões relacionadas à sua definição e à identificação da sua natureza e conteúdo. ${ }^{166}$

\footnotetext{
${ }^{164}$ BERCOVICI, Gilberto, O Ainda Indispensável Direito Econômico. In BENEVIDES, Maria Victoria de Mesquita; BERCOVICI, Gilberto \& MELO, Claudineu de (orgs.), Direitos Humanos, Democracia e República: Homenagem a Fábio Konder Comparato, São Paulo, Quartier Latin, 2009, p. 504. ${ }^{165}$ Ibidem.

${ }^{166}$ COMPARATO, Fábio Konder. O Indispensável Direito Econômico. In Estudos e Pareceres de Direito Empresarial. Rio de Janeiro, Forense, 1978, pp. 454-455.
} 
No século XIX, a Teoria do Estado tinha um caráter estritamente liberal, dado a transposição do método jurídico da Escola Pandectista do direito privado para o direito público. Tal método tinha como estratégia deliberada a contenção da decisão política, limitando ao máximo as possibilidades de atuação do Estado, e concebendo-o como um ente perfeitamente jurídico.

A personalidade jurídica do Estado vai dar coerência e credibilidade ao sistema de direito público e torná-lo ao mesmo tempo um ente soberano e limitado. O Estado tutelava os direitos e liberdades fundamentais, submetendo-se também à supremacia da lei. Neste contexto, com a negação das relações entre direito, Estado e economia, tornava-se impossível a discussão sobre um Direito Econômico. ${ }^{167}$

Esta visão liberal do Estado coincidia com a visão de economia política predominante à época, que concebia a ordem econômica como algo essencialmente estático, centrado em torno do equilíbrio natural entre a produção e circulação de riquezas. Daí o papel que era dado ao Estado, de garantir a manutenção deste equilíbrio e, eventualmente, de atuar como redutor de crises. ${ }^{168}$

Os autores estudados neste trabalho vão convergir em apontar a Primeira Guerra Mundial (1914-1918) como um momento decisivo em que haverá uma quebra desta lógica. Dado o esforço de guerra, o direito vai ser chamado a cobrir zonas cada vez mais extensas da vida econômica. Com ênfase no planejamento e na centralização, surgirá uma legislação abundante e minuciosa, que vai transformar as estruturas clássicas do direito patrimonial, abolindo princípios, deformando institutos e confundindo fronteiras. ${ }^{169} \mathrm{O}$ que era em princípio uma legislação excepcional de natureza transitória, vai se tornar perene com a nova organização do capitalismo no período pós-Primeira Guerra Mundial.

Se antes o capitalismo assentava as suas bases sobre a livre concorrência, o que vai dar a tônica à sua organização e expansão; neste momento será sobre a concentração de capital, com a formação de grandes conglomerados. A dominação burguesa vai precisar,

\footnotetext{
${ }^{167}$ BERCOVICI, Gilberto, O Ainda Indispensável Direito Econômico. In BENEVIDES, Maria Victoria de Mesquita; BERCOVICI, Gilberto \& MELO, Claudineu de (orgs.), Direitos Humanos, Democracia e República: Homenagem a Fábio Konder Comparato, São Paulo, Quartier Latin, 2009, pp. 504-508.

${ }^{168}$ COMPARATO, Fábio Konder. O Indispensável Direito Econômico. In Estudos e Pareceres de Direito Empresarial. Rio de Janeiro, Forense, 1978, pp. 462-463.

169 Ibidem, p. 456.
} 
então, de um Estado politicamente poderoso para garantir os mercados nacionais e a expansão econômica dos seus conglomerados. ${ }^{170}$

Os partidos socialdemocratas da Europa, com orientação marxista, vão defender que o papel do proletariado seria a tomada do poder, através do Estado, com vistas à desapropriação da oligarquia que controlava o capital financeiro. $\mathrm{O}$ conflito de classes vai então ser incorporado ao texto constitucional, especialmente com a Constituição de Weimar (1919) na Alemanha.

A constituição de Weimar, de 1919, não representa mais a composição pacífica do que já existe, mas lida com conteúdos políticos e com a legitimidade, em um processo contínuo de busca de realização de conteúdos, de compromisso aberto de renovação democrática, que visava a emancipação política completa e a igualdade de direitos, incorporando os trabalhadores ao Estado. ${ }^{171}$

Weimar e seu "Estado econômico" consolidam uma posição privilegiada do Direito Econômico. Na Alemanha vai ser fundado, pelo jurista Justus Wilhelm Hedemann, o "Instituto de Direito Econômico". Hedemann é quem utiliza, pela primeira vez, a expressão "Direito Econômico" como uma nova disciplina jurídica, como veremos mais a frente. Fato é que o Estado pós-liberal, que começava a se organizar, não poderia mais prescindir de normas de forte conteúdo econômico.

A crise de 1929 também impacta a produção jurídica dos países nela envolvidos. A crise provocada por uma expansão desordenada da produção e do consumo nos EUA, e por uma queda nas importações europeias, vai provocar uma queda vertiginosa nas bolsas de valores dos EUA e do velho continente, causando forte recessão e desemprego em massa.

Desaparecia, neste contexto, a pujança da iniciativa econômica privada, restando ao Estado deixar de lado o seu papel de unicamente estabelecer e promover o respeito às regras do jogo econômico. Ao Estado caberá, nesse momento, o impulso da atividade econômica, através da intervenção no domínio econômico, com regulação de moeda, crédito, produção, criação de empresas públicas e realização de grandes obras.

\footnotetext{
${ }^{170}$ BERCOVICI, Gilberto, O Ainda Indispensável Direito Econômico. In BENEVIDES, Maria Victoria de Mesquita; BERCOVICI, Gilberto \& MELO, Claudineu de (orgs.), Direitos Humanos, Democracia e República: Homenagem a Fábio Konder Comparato, São Paulo, Quartier Latin, 2009, p. 510.

${ }^{171}$ Ibidem, p. 511.
} 
O impulso econômico estatal (...) manifestou-se por uma autêntica proliferação de textos jurídicos de todos os graus, extravagando da condição clássica e acarretando sérias distorções à dogmática tradicional. $^{172}$

Com a Segunda Guerra Mundial e as necessidades de financiamento público que ela impunha, surgem novas formas de captação da poupança individual por parte do Estado, como os empréstimos compulsórios e a emissão de títulos da dívida pública, que vão se configurar em novos instrumentos do Direito Econômico.

A ação econômica do Estado moderno deixa de ser episódica ou pontual e torna-se sistêmica. A economia torna-se cada vez mais regulamentada e administrada, ou seja, jurídica. Isto porque o direito contemporâneo vai sistematizar e tornar permanente as normas surgidas das necessidades de guerra, conformando-as para atingir novos objetivos, como a corrida armamentista, a concentração do poder econômico nos países industrializados e, no mundo subdesenvolvido, a promoção de uma política de desenvolvimento. ${ }^{173}$

Assim, estes três momentos da história mundial no século XX (duas grandes guerras e a crise de 1929), somados à sistematização dos fundamentos teóricos para a atuação do Estado na economia realizada por Keynes em $1936^{174}$, formatam um novo direito, que não se enquadrará nas formas e ramos tradicionais da ciência jurídica. Pelo contrário, a penetração das normas de forte conteúdo econômico no ordenamento jurídico vai desafiar a doutrina no sentido da classificação e delimitação deste novo ramo jurídico.

Aponta Fabio Konder Comparato que a doutrina passa a reagrupar as disciplinas jurídicas, visando a integrar as normas de direito econômico, que a princípio não se enquadravam no binômio direito privado-público. Ainda para Comparato, alguns autores vão além do mero reenquadramento de normas e vão conceber o Direito Econômico como uma espécie de ordenamento constitucional da economia, contendo

\footnotetext{
${ }^{172}$ COMPARATO, Fábio Konder. O Indispensável Direito Econômico. In Estudos e Pareceres de Direito Empresarial. Rio de Janeiro, Forense, 1978, p. 457.

${ }^{173}$ Ibidem, p. 458.

${ }^{174}$ KEYNES, John Maynard. Teoria Geral do Emprego, do Juro e da Moeda. Lisboa: Relógio D’Água Editores, 2010.
} 
princípios e regras que irão disciplinar as instituições econômicas. Seria então a tradução jurídica da economia dirigida. ${ }^{175}$

Este último entendimento é o que mais se aproxima da concepção desenvolvida pelo autor, que vai entender o Direito Econômico como:

(...) o conjunto das técnicas jurídicas de que lança mão o Estado contemporâneo na realização de sua política econômica. Ele constitui assim a disciplina normativa da ação estatal sobre as estruturas do sistema econômico. ${ }^{176}$

O Direito Econômico, para este mesmo autor, seria então um ramo do direito aplicado, supondo o conhecimento de categorias jurídicas tradicionais tanto do direito público quanto do direito privado. Sua utilidade, no que diz respeito ao aspecto formal, é a de possibilitar o estudo sistemático de várias matérias que dificilmente se enquadrariam todas dentro de um dos ramos jurídicos tradicionais. Já no aspecto teleológico, o Direito Econômico cumpriria a função de aperfeiçoar constantemente as instituições jurídicas tendo em vista os seus objetivos concretos. ${ }^{177}$

Eros Grau, por sua vez, afirma que hoje o Direito Econômico é reconhecido pela própria Constituição Brasileira (art. 24, I), podendo ser concebido tanto como um ramo quanto como um método de análise. O que peculiariza o Direito Econômico como um ramo do direito é a sua destinação de instrumentalização da política econômica do Estado. É a este Direito Econômico que a Constituição se refere no seu artigo 24. É a disciplina que se destina a traduzir normativamente a política econômica do Estado.

Já o Direito Econômico enquanto método é a opção por uma interpretação essencialmente teleológica, funcional, que instrumentalizará toda a interpretação jurídica, conformando, assim, a interpretação do direito como um todo. O Direito Econômico criaria assim uma moldura, um ângulo novo sob o qual seriam estudados os fenômenos jurídicos com implicações econômicas. É um método de análise substancial

\footnotetext{
175 COMPARATO, Fábio Konder. O Indispensável Direito Econômico. In Estudos e Pareceres de Direito Empresarial. Rio de Janeiro, Forense, 1978, pp. 460-462.

176 Ibidem, p. 465.

${ }^{177}$ Ibidem, pp. 470-472.
} 
e crítica, com possibilidade transformadora, tornando-se, assim, não um direito de síntese, mas um sincretismo metodológico. ${ }^{178}$

Gilberto Bercovici aponta que, apesar de muitos autores, vinculados ao direito privado, entenderem o Direito Econômico como o "direito da organização dos mercados", a concepção majoritária é a de que ele seria o "direito da intervenção estatal na economia". Neste sentido, não estamos diante de um direito geral da economia, mas de um direito específico, que trata da intervenção do Estado no domínio econômico.

\subsubsection{Formas de atuação do Estado no domínio econômico}

No que diz respeito às ferramentas (ou instrumentos) para a execução da política econômica, o professor Comparato distingue duas formas de atuação do Estado. A primeira se dá quando o Estado age de forma unilateral, exercendo as suas prerrogativas de imperium, enquanto a outra seria quando ele atua de forma colaborativa junto a agentes econômicos privados.

Como exemplos da primeira forma de atuação estatal estariam a regulação do crédito do sistema bancário e da exploração dos recursos minerais (atuação direta do Estado através da elaboração de normas impositivas), e também a atuação no domínio econômico através das suas empresas públicas descentralizadas (aqui a atuação é realizada de maneira indireta).

Já na atuação colaborativa com os agentes privados, há a formação das sociedades de economia mista (cujo capital é composto pelo Estado e pelos agentes privados) e as relações de economia mista (técnicas contratuais de colaboração entre o setor público e o privado). ${ }^{179}$

A melhor sistematização das formas de atuação estatal, entretanto, é aquela feita por Eros Grau. $\mathrm{O}$ autor vai fazer uma distinção entre atividade econômica em sentido amplo e atividade econômica em sentido estrito, para dizer que nem toda atuação estatal é propriamente uma intervenção. Afinal, o vocábulo intervenção implica em uma atuação

\footnotetext{
${ }^{178}$ GRAU, Eros Roberto, A Ordem Econômica na Constituição de 1988 (Interpretação e Crítica), 12ªed., São Paulo, Malheiros, 2007, pp. 152-155.

${ }^{179}$ COMPARATO, Fábio Konder. O Indispensável Direito Econômico. In Estudos e Pareceres de Direito Empresarial. Rio de Janeiro, Forense, 1978, pp. 467-469.
} 
no domínio de outrem, e a Constituição reserva para o Estado alguns setores da atividade econômica. $^{180}$

Assim sendo, atuação estatal vai denotar atuação do Estado tanto em áreas de sua titularidade como em áreas do setor privado, ou seja, atividade econômica em sentido amplo. Já intervenção implica, necessariamente, em atuação estatal em áreas de titularidade do setor privado.

A distinção feita será importante para compreender a atuação do Estado na prestação de serviços públicos. Os serviços públicos se enquadram no conceito de atividade econômica em sentido amplo, mas não em sentido estrito, dado que a Constituição reserva para o Estado a sua execução. Grau define serviço público como

atividade indispensável à consecução da coesão social. (...) o que determina a caracterização de determinada parcela da atividade econômica em sentido amplo como serviço público é a sua vinculação ao interesse social. ${ }^{181}$

Segundo a classificação feita por Eros Grau, são três as modalidades de intervenção do Estado no domínio econômico. O Estado pode intervir na economia por absorção (ou participação), por direção ou indução. Na primeira, o Estado intervém no domínio econômico, enquanto que nas duas últimas intervém sobre o domínio econômico.

$\mathrm{Na}$ intervenção por absorção, o Estado é sujeito da atividade econômica, assumindo para si todo um setor da atividade econômica em sentido estrito, executando-a sob o regime de monopólio. Quando o faz em regime de competição com outras empresas privadas, há a intervenção por participação.

Na modalidade de intervenção por direção o Estado não é propriamente sujeito da atividade econômica, entretanto, vai exercer um papel regulador sobre essa atividade. Vai exercer pressão sobre a economia, estabelecendo normas compulsórias para os agentes privados que atuam em determinado setor. São comandos imperativos, dotados de cogência, isto é, impositivos de certos comportamentos. Exemplo dessa modalidade de atuação é o controle de preços.

\footnotetext{
${ }^{180}$ GRAU, Eros Roberto, A Ordem Econômica na Constituição de 1988 (Interpretação e Crítica), 12aed., São Paulo, Malheiros, 2007, pp. 148-155.

${ }^{181}$ Ibidem, p. 130.
} 
Já na intervenção por indução, o Estado também vai agir como regulador, entretanto manipula as normas e regulamentos em conformidade com as leis do mercado. Aqui, as normas não são dotadas do mesmo nível de cogência da intervenção por direção. Ao contrário, são normas dispositivas, que buscam incentivar determinados comportamentos por parte dos agentes econômicos. É o campo típico da sanção premial, que se configura como um convite ao setor privado para atuar em conformidade com aquilo que o Estado elege, através da sua política econômica, como interesse coletivo e social.

No que diz respeito aos serviços públicos (atividade econômica em sentido amplo), eles podem ser prestados tanto pelo Estado quanto por particulares. Há uma divisão dos serviços públicos entre os privativos, cuja prestação é exclusiva do Estado, admitida, entretanto, a possibilidade de particulares o exercerem mediante concessão, autorização ou permissão (Constituição Federal, art. 175), e os serviços públicos não privativos, que podem ser prestados pelo setor privado independente de concessão, permissão ou autorização, como no caso da saúde e da educação.

Importante notar que, quando empresas estatais (sociedades de economia mista ou empresas públicas) prestam serviço público elas não serão concessionárias, mas, sim, delegadas do Estado. Não há também que se falar em monopólio no campo dos serviços públicos, mas, sim, em um privilégio do Estado. A caracterização de determinada atividade econômica como serviço público ou atividade econômica em sentido estrito vai ser importante para identificar o regime jurídico a que estão submetidas as empresas estatais que a exercem. ${ }^{182}$

Eros Grau ${ }^{183}$ sustenta que a Constituição encerra todos os elementos para a definição de serviço público e retoma o pensamento do francês Léon Duguit para expor a sua concepção de serviço público, que deve ser construída, para o autor, sobre as noções de interdependência social e coesão. Por ter essas duas características, determinada parcela da atividade econômica assume o caráter de serviço público, devendo ser prestada à sociedade pelo Estado ou por outra pessoa administrada. A identificação dos casos nos quais os referidos elementos estão presentes estaria conformada pela própria

\footnotetext{
${ }^{182}$ Para uma discussão aprofundada sobre o tema ver GRAU, Eros Roberto, A Ordem Econômica na Constituição de 1988 (Interpretação e Crítica), 12a ed., São Paulo, Malheiros, 2007, pp. 132-148.

${ }^{183}$ GRAU, Eros Roberto. Constituição e Serviço Público. In GRAU, Eros Roberto e GUERRA FILHO, Willis Santiago (orgs). Direito Constitucional: estudos em homenagem a Paulo Bonavides. Malheiros: São Paulo, 2003, pp. 249-267.
} 
Constituição. Através de uma interpretação sistemática da carta maior, defende o autor, o que inclui a consideração das suas diretrizes, programas e fins, seria possível a delimitação das atividades que devem ser prestadas pelo Estado e aquelas que devem ficar sob o regime da livre iniciativa.

A discussão sobre a noção de serviço público, entretanto, é mais complexa e está longe de ser unívoca. ${ }^{184}$ Especialmente por conta das transformações oriundas das reformas constitucionais dos anos 1990, é especialmente tênue e nebulosa a separação entre o que seria atividade econômica em sentido estrito e serviço público. Isso se deve, principalmente, à introdução do regime de competição em diversas áreas consideradas como serviço público, como a energia elétrica e a telefonia. E, por outro lado, temos o exemplo do setor de exploração e produção de petróleo, considerado atividade econômica em sentido estrito, onde há uma flexibilização do monopólio estatal, com a instituição de um regime de concessões, o que aproxima também este setor da forma tradicional de organização e prestação dos serviços públicos.

Em resumo, passa-se, com as privatizações e concessões, de um regime único de publicacio nos serviços públicos a um regime de liberdade econômica regulada. ${ }^{185}$ Enquanto na estruturação tradicional todo o setor da atividade era absorvido pela prestação estatal e pela derrogação da concorrência, no formato caudatário das reformas econômicas, somente algumas etapas da cadeia econômica vão ser abrangidas por um regime de derrogação parcial da concorrência.

Floriano Azevedo Marques Neto ${ }^{186}$ defende que não há uma redução da atividade estatal, mas, pelo contrário, um aumento das áreas com forte regulação do Estado. Para o autor, há uma mudança do eixo de intervenção e outra no perfil da regulação. A mudança do eixo de intervenção estatal traduz-se numa diminuição, causada pela crise de financiamento do Estado e pela abertura econômica, da intervenção estatal direta. Em paralelo a esta diminuição, há um aumento da intervenção estatal sobre o domínio

\footnotetext{
${ }^{184}$ Para pontos de vista diversos sobre este tema, ver: MEDAUAR, Odete. Serviços Públicos e serviços de interesse econômico geral. In MOREIRA NETO, Diogo de Figueiredo (coord.). Uma avaliação das tendências contemporâneas do direito administrativo: obra em homenagem a Eduardo García de Enterría. Renovar: Rio de Janeiro e São Paulo, 2003, pp. 115-126; MELLO, Celso Antonio Bandeira de. Serviço Público e sua feição constitucional no Brasil. In MODESTO, Paulo e MENDONÇA, Oscar (orgs.). Direito do Estado: novos rumos. Tomo II. Max Limonad: São Paulo, 2001, pp. 13-35; e ARAGÃO, Alexandre Santos de. Direito dos Serviços Públicos. $2^{\mathrm{a}}$ ed. Forense: Rio de Janeiro, 2008.

${ }^{185}$ MARQUES NETO, Floriano de Azevedo. A nova regulação dos serviços públicos. In Revista de Direito Administrativo v.228. Renovar: Rio de Janeiro, 2002, pp. 13-29.

${ }^{186}$ Ibidem.
} 
econômico nos setores em que o Estado se retira da exploração direta de atividade econômica, e também em outros setores, nos quais a atuação regulatória era tímida. Há uma ampliação e sofisticação da intervenção regulatória estatal em áreas como a saúde suplementar, vigilância sanitária, recursos hídricos e transportes. Há também mudança no perfil da regulação, com o Estado deixando de ser adjudicador de direitos e passando a ser mediador de interesses.

Mais a frente, veremos que a previdência social não passou incólume às alterações constitucionais da década de 1990. Apesar de não se poder falar técnicamente em um processo de privatização, as Emendas Constitucionais 20/1998 e 41/2003 alargaram os espaços para a atuação da entes privados ou semi-públicos (como o caso dos fundos de pensão das empresas estatais), mantendo em todos os casos a atuação do Estado sobre o domínio econômico, através da atividade de regulação. Testaremos, posteriormente, a hipótese deste trabalho, a qual enuncia que, por conta do caráter dos fundos semipúblicos das Entidades Fechadas de Previdência Complementar, estas constituem também uma forma de atuação do Estado no domínio econômico.

\subsection{Antecedentes da Regulação da Previdência}

Ao fazer uma retomada histórica da previdência social no Brasil, Maria Jardim ${ }^{187}$ aponta que a primeira forma de pensar as incertezas no país foi o mutualismo, ainda no período anterior à proclamação da República, com as Santas casas de misericórdia. A previdência social surgiria somente na segunda década do século $\mathrm{XX}$, num contexto de rompimento com o liberalismo dominante na República Velha. As transformações econômicas em curso no país à época fizeram surgir um novo ator político que teria importância central para a construção do modelo previdenciário brasileiro: o operariado. De forma direta ou indireta, os operários, através de suas organizações sindicais, sempre participaram do debate em torno da previdência. As reivindicações, bem como a forma de participação dos trabalhadores na previdência, irão sofrer transformações ao longo do século, culminando com a forte participação dos sindicatos nos atuais fundos de pensão.

O mutualismo consistia numa forma de autoproteção dos trabalhadores que organizavam as suas "caixinhas", com arrecadação coletiva de recursos para amparo daqueles mais necessitados no momento. Estão presentes aqui, algumas das ideias que

\footnotetext{
${ }^{187}$ JARDIM, Maria A. Chaves. Entre a solidariedade e o risco: sindicatos e fundos de pensão em tempos de governo Lula. São Paulo: Annablume, Fapesp, 2009, pp. 27-67.
} 
iriam ser posteriormente consagradas nas formas modernas de previdência social alinhadas com o Estado de Bem Estar Social, como o sistema de repartição e a solidariedade intergeracional entre os trabalhadores, referidos acima. ${ }^{188}$ Esta forma de pensar as incertezas aparece, ao lado da beneficência privada, seja laica ou religiosa, e da criação dos Montépios, conformam, para Maria Fernanda Redi ${ }^{189}$, a primeira das 6 (seis) fases da evolução da proteção social no Brasil, qualificada por Wladmir Novaes Martinez como a "pré-história" da Previdência Social em nosso país. ${ }^{190}$ Vejamos, segundo a classificação de Redi, os principais elementos e legislações que caracterizaram as 5 (cinco) fases posteriores desta evolução.

A segunda fase diz respeito ao aparecimento das Caixas de Aposentadoria e Pensões (CAPs) por ramo de atividade empresarial, regulados pelo Decreto Legislativo $\mathrm{n}^{\circ} 4.682$ de 1923 (Lei Eloy Chaves). Esta norma veio para regrar as CAPs dos Ferroviários, cujos recursos seriam arrecadados a partir de contribuições mensais dos trabalhadores e anuais dos empresários. A Lei Eloy Chaves serviu de inspiração para outras CAPs que surgiriam posteriormente.

A terceira fase tem início com a criação do Instituto dos Maritimos, em 1933, que marca o surgimento de grandes Institutos de Aposentadorias e Pensões (IAPs). Os IAPs partem da mesma ideia de constituição de fundos das CAPs, entretanto sua base de organização são as categorias profissionais (marítimos, bancários, comerciários) e não as empresas. O Decreto-Lei n 627/1938 vem regulamentar sua existência. Note-se que a organização por categoria profissional vai ao encontro do modelo corporativista de organização sindical do Estado Novo de Getúlio Vargas.

Todavia, apesar da regulamentação estatal, o arcabouço normativo permanecia complexo e heterogêneo, com regras e benefícios próprios de cada um destes IAPs. Há uma tentativa de uniformização legislativa com o Decreto-Lei $n^{\circ} 7.526 / 1945$. O referido diploma legal visava a unificar os institutos de previdência social do país no âmbito do Instituto de Serviços Sociais do Brasil (ISSB). No entanto, a medida não prosperou

188 GUIMARÃES, Magda Cristiane Monteiro. Estudo do programa de educação financeira nas Entidades Fechadas de Previdência Complementar. In MINISTÉRIO DA PREVIDẾNCIA SOCIAL. $2^{\circ}$ Prêmio PREVIC de Monografias: previdência complementar fechada. Brasília, 2010, pp. 77-84.

${ }^{189}$ REDI, Maria Fernanda de Medeiros. Fundamentos da Regulação da Previdência Privada no Brasil. Tese de Doutorado em Direito Econômico apresentada na Faculdade de Direito da USP. São Paulo, 2004, pp. 120-127.

${ }_{190}$ MARTINEZ, Wladmir Novaes. Curso de Direito Previdenciário. Tomo II: Previdência Social. São Paulo, LTr, 1998, p. 41. 
dado que promulgada no final do regime do Estado Novo, pouco tempo antes da deposição de Getúlio Vargas.

Na quarta fase evolutiva conforme a classificação supramencionada de Redi, é promulgada da Lei Orgânica da Previdência Social (LOPS), Lei nº 3.807/1960. A LOPS manteve a setorização organizacional por categorias, entretanto logrou unificar contribuições e prestações dos diferentes institutos. Foi apenas na quinta fase que foi consumada a unificação dos institutos, através do Decreto $n^{\circ} 60.501 / 1966$, durante a ditadura militar, que incluiu todos os trabalhadores da iniciativa privada sob a proteção do Instituto Nacional da Previdência Social (INPS).

No que se refere à previdência privada, a Lei 6.435/1977 institucionaliza as suas atividades, regulamentando-as e colocando-as sob a supervisão estatal. Apesar de já existirem entidades de previdência privada, a partir desta lei que o mercado foi ampliado, e a expressão "previdência privada" começou a ser utilizada largamente. ${ }^{191}$ A Lei $\mathrm{n}^{\circ}$ 6.435/1977 trouxe as definições de entidade aberta e entidade fechada de previdência privada. A entidade seria fechada no caso de ser acessível apenas aos empregados de determinada empresa ou de um grupo de empresas, denominadas de patrocinadoras, e abertas quando não houvesse restrição de acesso. Nota-se que estas definições são semelhantes às usadas atualmente pela legislação nacional.

As entidades abertas integravam, segundo a Lei, o Sistema Nacional de Seguros Privados, submetendo-se à regulamentação do seu órgão normativo e à fiscalização do seu órgão executivo, enquanto as entidades fechadas foram definidas como "complementares" ao sistema oficial de Previdência Social, submetendo-se à regulamentação e fiscalização do Ministério da Previdência e Assistência Social, que também seria responsável por expedir autorização para o seu funcionamento. As disposições da Lei 6.435/1977 vigeram até 2001, quando foi promulgada a Lei Complementar $\mathrm{n}^{\circ} 109$ que expressamente a revogou.

A sexta fase da evolução da previdência social, para Redi, diz respeito à promulgação da Constituição Federal de 1988 e posteriores leis ordinárias e complementares, que serão tratadas no item a seguir.

\footnotetext{
191 JARDIM, Maria A. Chaves. Entre a solidariedade e o risco: sindicatos e fundos de pensão em tempos de governo Lula. São Paulo: Annablume, Fapesp, 2009, pp. 27-67.
} 


\subsection{Seguridade Social na Constituição de 1988}

Elaborada num contexto de ascensão das lutas populares no país, após a derrubada do regime militar, a Constituição Federal de 1988 foi pródiga na garantia de direitos sociais e, como já vimos, na afirmação da atuação do Estado na ordem econômica para a superação de desigualdades, prevendo um programa político para o Brasil. A Constituição reservou o Capítulo II do seu Título VIII (Da Ordem Social) às disposições sobre a Seguridade Social, dividindo este capítulo em 3 Seções, cada uma referente a um dos eixos componentes da seguridade: saúde, previdência e assistência social. ${ }^{192}$

Há ainda disposições esparsas sobre seguridade e, em específico, sobre a previdência, a exemplo daquelas mencionadas anteriormente, que dizem respeito às competências administrativas e legislativas da União, além das disposições sobre a previdência dos servidores públicos, contidas no capítulo sobre a Administração Pública; e ainda dispositivo sobre o orçamento da seguridade social, o qual deve constar como uma peça orçamentária específica na Lei Orçamentária Anual encaminhada pelo Poder Executivo $\left(\right.$ art. $\left.165, \S 5^{\circ}\right)$.

O capítulo referente à Seguridade Social afirma logo de início (art. 194) os objetivos do Poder Público em suas ações na área, elencados abaixo. Para Fábio Ibrahim, todavia, trata-se de princípios e não objetivos, pois, ao descrever as normas elementares da seguridade, direcionam toda a atividade legislativa e interpretativa da seguridade social $^{193}$ :

$$
\begin{aligned}
& \text { I - universalidade da cobertura e do atendimento; } \\
& \text { II - uniformidade e equivalência dos benefícios e serviços às } \\
& \text { populações urbanas e rurais; } \\
& \text { III - seletividade e distributividade na prestação dos benefícios e } \\
& \text { serviços; } \\
& \text { IV - irredutibilidade do valor dos benefícios; } \\
& \text { V - eqüidade na forma de participação no custeio; }
\end{aligned}
$$

\footnotetext{
192 Restringiremo-nos, por conta do escopo do trabalho, ao estudo dos dispositivos que dizem respeito à Previdência Social. A saúde e a assistência organizam-se em sistemas - Sistema Único de Saúde e Sistema Único de Assistência Social - com participação de todos os níveis federativos, bem como de usuários e da sociedade em sua gestão, e são regulados pelas Leis nº 8.080/1990 (SUS) e nº 8.742/1993 (SUAS).

193 IBRAHIM, Fábio Zambitte. Curso de direito previdenciário. 15. ed., rev., amp. e atual. Niterói, RJ: Impetus, 2010, pp. 69-70. É corrente na doutrina que estes sejam chamados de princípios, e não objetivos da seguridade social, por isso, optamos por esta classificação em nosso trabalho.
} 
VI - diversidade da base de financiamento;

VII - caráter democrático e descentralizado da administração, mediante gestão quadripartite, com participação dos trabalhadores, dos empregadores, dos aposentados e do Governo nos órgãos colegiados.

O princípio da universalidade tem dupla dimensão: uma subjetiva e outra objetiva. ${ }^{194} \mathrm{~A}$ dimensão objetiva diz respeito à cobertura de todos os riscos sociais (universalidade de cobertura) enquanto a subjetiva fala sobre a possibilidade de qualquer pessoa obter a tutela do sistema protetivo. No caso da assistência e da saúde, isto se dá de forma plena (com a contingência financeira dos recursos estatais), mas, na previdência social, este princípio é relativizado pelo caráter contributivo da proteção (benefícios são percebidos a partir de contribuição), limitando-se assim, àqueles que vivem do seu trabalho. ${ }^{195}$

O princípio da uniformidade entre campo e cidade corrige distorção persistente até 1988, que dispensava regramento previdenciário distinto para o trabalhador rural. Com a previsão constitucional, estende-se ao trabalhador rural, por exemplo, o valor de um salário mínimo como piso para a aposentadoria. Todavia, alerta Ibrahim $^{196}$ que este princípio não deve ser olhado de forma isolada, mas, sim, aplicado junto com a ideia de isonomia, prevendo igualdade material entre trabalhadores do campo e da cidade. Daí decorre o fato de a própria Constituição, no artigo seguinte, estabelecer contribuição diferenciada para o "produtor, o parceiro, o meeiro e o arrendatário rurais e o pescador artesanal" que exerçam suas atividades em regime de economia familiar ( $\operatorname{art.} 195, \S^{\circ}$ ).

No que diz respeito à seletividade na prestação dos benefícios, esta entraria em conflito aparente com a universalidade. Fábio Ibrahim $^{197}$ fala da necessidade de se realizar escolhas trágicas para a aplicação de recursos escassos, enquanto Marcus Orione ${ }^{198}$ entende que a seletividade só pode ser determinada pela própria Constituição. Já a

\footnotetext{
${ }^{194}$ IBRAHIM, Fábio Zambitte. Curso de direito previdenciário. 15. ed., rev., amp. e atual. Niterói, RJ: Impetus, 2010, p. 71.

${ }_{195}$ CORREIA, Marcus Orione Gonçalves; CORREIA, Érica Paula Barcha. Curso de direito da seguridade social. São Paulo, Saraiva, 2002, p. 97.

${ }^{196}$ IBRAHIM, op. cit., p. 72.

${ }^{197}$ Ibidem.

198 CORREIA, Marcus Orione Gonçalves; CORREIA, Érica Paula Barcha. Curso de direito da seguridade social. São Paulo, Saraiva, 2002, p. 101.
} 
distributividade objetiva a uma redução de desigualdades regionais ${ }^{199}$ e sociais. Para Maria Fernanda Redi ${ }^{200}$, o principal feito da Constituição da 1988 no que se refere à Seguridade Social, foi exatamente ter privilegiado a distribuição de renda e reforçado a solidariedade social, o que se expressa neste princípio, mas também no princípio da universalidade, na criação da aposentadoria rural e no estabelecimento do piso de um salário-mínimo.

Quanto à irredutibilidade no valor dos benefícios, pode-se dizer que se refere não só ao valor nominal percebido pelo beneficiário, mas também à necessidade de atualização monetária periódica para manter o valor real. Este é o entendimento de Sérgio Pinto Martins e Fábio Ibrahim ${ }^{201}$, corroborado pelo art. 201, $\$ 4^{\circ}$. Entretanto, há decisões do STF que apontam em sentido contrário, prevendo que há apenas um dever de abstenção do Estado de não reduzir o valor nominal. ${ }^{202}$

Já a equidade na forma de participação no custeio é um desdobramento do princípio da igualdade, e estabelece que quem ganha igual deve contribuir também de forma igual para o financiamento da previdência. ${ }^{203}$ Entretanto, aponta Fábio Ibrahim que o dispositivo abre a possibilidade de o legislador estabelecer alíquotas diferenciadas com base em diversos fatores, como a mão de obra empregada, a exemplo do art. $239, \S 4^{\circ}$ da Constituição.

A diversidade na base de financiamento é desdobrada no artigo posterior da Constituição, que enumera as contribuições da Seguridade Social, que devem ser custeadas por empregadores, trabalhadores e por toda a sociedade, por meio de impostos. Já a previsão de caráter democrático e descentralizado da administração visa à participação dos diferentes setores sociais na gestão da seguridade social, o que está em consonância com a sua previsão de custeio.

\footnotetext{
${ }^{199}$ Muitos municípios brasileiros, especialmente os pequenos, têm sua economia aquecida quando da percepção de benefícios da previdência social. Ver FRANÇA, Álvaro Sólon. A Previdência Social e a Economia dos Municípios. Brasília, ANFIP, 1999.

${ }^{200}$ REDI, Maria Fernanda de Medeiros. Fundamentos da Regulação da Previdência Privada no Brasil. Tese de Doutorado em Direito Econômico apresentada na Faculdade de Direito da USP. São Paulo, 2004, p. 128.

${ }^{201}$ MARTINS, Sérgio Pinto. Fundamentos de direito da seguridade social. 5. ed. São Paulo: Atlas, 2004, p.31, e IBRAHIM, Fábio Zambitte. Curso de direito previdenciário. 15. ed., rev., amp. e atual. Niterói, RJ: Impetus, 2010, pp. 74-75.

${ }^{202}$ Ver RE 298.694 e MS 24.875-1.

${ }^{203}$ MARTINS, op. cit., p. 31.
} 
Há que se destacar no art.195, que dispõe sobre as diversas contribuições para a Seguridade Social, a inexistência de vinculação dos recursos arrecadados para a Previdência Social, mas, sim, a integração do custeio da seguridade social, com a destinação destes recursos tanto para a previdência quanto para assistência e saúde.

Ainda na análise do art. 195, percebe-se a clara opção política do constituinte brasileiro em estabelecer um sistema de proteção social inspirado nos modelos de bem-estar social, com participação decisiva do Estado na sua sustentação financeira. ${ }^{204}$ Isto não elimina a existência de um segundo pilar, complementar ao público, atrelado a outra forma de acumulação, entretanto torna imprópria a ideia largamente difundida de que haveria déficits na Previdência Social ${ }^{205}$. Ora, é a própria Constituição que prevê a existência de aportes estatais, não só por meio dos recursos arrecadados com as contribuições elencadas no art. 195, mas também "mediante recursos provenientes dos orçamentos da União, dos Estados, do Distrito Federal e dos Municípios".

Com esta afirmação, não estamos desconsiderando os impactos das mudanças do perfil demográfico no equilíbrio atuarial da Previdência, muito menos a escassez de recursos para que o Estado dê conta de uma série de serviços públicos, investimentos e proteção social; mas, colocando o debate em outro nível: trata-se de uma escolha política da sociedade brasileira a distribuição orçamentária e a forma de realizar a proteção social, que, no limite, diz respeito à alocação dos impostos arrecadados de todos. Ou seja, a discussão é menos se os recursos gerais do orçamento devem financiar a proteção por meio da previdência, mas como, em quais condições e qual o montante deste financiamento, tendo em vista o atendimento a outras funções estatais e às necessidades do país.

\footnotetext{
${ }^{204}$ PAULANI, Leda Maria. Seguridade social, regimes previdenciários e padrão de acumulação: uma nota teórica e uma reflexão sobre o Brasil. In FAGNANI, Eduardo; HENRIQUE, Wilnês; e LÚCIO, Clemente Ganz (orgs.). Previdência Social: Como incluir os excluídos. LTr: São Paulo, 2008, p. 24.

${ }^{205}$ O "déficit" da Previdência seria oriundo do resultado negativo observado desde 1995 entre as prestações percebidas pelo INSS e as despesas realizadas com o pagamento de benefícios. Todavia, este cálculo é contestado por desconsiderar entre as "receitas" da Previdência Social as contribuições do art. 195 recolhidas pelo Estado, REDI, Maria Fernanda de Medeiros. Fundamentos da Regulação da Previdência Privada no Brasil. Tese de Doutorado em Direito Econômico apresentada na Faculdade de Direito da USP. São Paulo, 2004, pp. 161-167. Para a defesa da tese do déficit, ver ORNÉLAS, Waldeck. Desatando o nó da previdência. Senado Federal, Brasília, 2002, pp. 31-109; ver também, CECHIN, José; CECHIN, Andrei Domingues. Desequilíbrios: Causas e soluções. In GIAMBIAGI, Fábio; TAFNER, Paulo. (orgs.) Previdência no Brasil: debates dilemas e escolhas. IPEA, Rio de Janeiro, 2007, pp. 219263.
} 


\subsubsection{Previdência Social na Constituição de 1988}

A Previdência Social é um seguro com caráter sui generis ${ }^{206}$, pois é de filiação compulsória nos seus dois regimes básicos: Regime Geral da Previdência Social e Regime Próprio da Previdência Social (definições estão adiante). Além disso, é um regime coletivo, contributivo e de organização estatal ${ }^{207}$, embora de gestão descentralizada e com participação de outros setores da sociedade, como vimos anteriormente. Destina-se a cobrir os chamados riscos ou necessidades sociais elencados nos incisos do art. $201^{208}$ :

Art. 201. A previdência social será organizada sob a forma de regime geral, de caráter contributivo e de filiação obrigatória, observados critérios que preservem o equilíbrio financeiro e atuarial, e atenderá, nos termos da lei, a: (Redação dada pela Emenda Constitucional n ${ }^{\circ} 20$, de 1998)

I - cobertura dos eventos de doença, invalidez, morte e idade avançada; (Redação dada pela Emenda Constitucional nº 20, de 1998)

II - proteção à maternidade, especialmente à gestante; (Redação dada pela Emenda Constitucional n ${ }^{\circ} 20$, de 1998)

III - proteção ao trabalhador em situação de desemprego involuntário; (Redação dada pela Emenda Constitucional n ${ }^{\circ} 20$, de 1998)

IV - salário-família e auxílio-reclusão para os dependentes dos segurados de baixa renda; (Redação dada pela Emenda Constitucional $\underline{\left.\mathrm{n}^{\circ} 20, \text { de } 1998\right)}$

V - pensão por morte do segurado, homem ou mulher, ao cônjuge ou companheiro e dependentes, observado o disposto no $\S 2^{\circ}$. (Redação dada pela Emenda Constitucional no 20, de 1998)

\footnotetext{
${ }^{206}$ IBRAHIM, Fábio Zambitte. Curso de direito previdenciário. 15. ed., rev., amp. e atual. Niterói, RJ: Impetus, 2010, p. 29.

${ }^{207}$ TAVARES, Marcelo Leonardo. Direito Previdenciário. $9^{\mathrm{a}}$ ed. Lumen Iuris, Rio de Janeiro, 2007, p. 29.

${ }^{208}$ Dentre os riscos sociais, o desemprego involuntário é o único que não integra os benefícios do Regime Geral de Previdência Social, não tendo cobertura do Instituto Nacional da Seguridade Social (INSS). O benefício correspondente a este risco social é o seguro-desemprego, cujo pagamento é operado pela Caixa Econômica Federal e Ministério do Trabalho e Emprego, ver TAVARES, op. cit., p. 51.
} 
Trata-se de um regime de repartição simples ${ }^{209}$, no qual todo o montante arrecadado é utilizado para o pagamento dos benefícios contemporâneos, não havendo qualquer reserva de contingência. Vimos anteriormente que nos regimes de repartição está intrínseca a ideia de solidariedade intergeracional e não é diferente com o pilar público da previdência brasileira, no qual a geração atual contribui para os benefícios da geração anterior.

A Constituição traz a previsão expressa (art. 201) do vínculo contributivo existente na relação entre o pagamento das contribuições e a possibilidade de perceber o benefício, entretanto este vínculo é flexibilizado pelos elementos de solidariedade presentes na Previdência Social brasileira, inclusive no próprio texto constitucional que estabelece critérios diferenciados para grupos sociais considerados mais vulneráveis, a exemplo $\operatorname{dos} \S \S 1^{\circ}$ e 12 do art. 201.

A compulsoriedade na filiação também é característica decorrente da solidariedade do sistema, e diz respeito a todos que exercem atividade remunerada no país, não apenas àqueles com relação de emprego, excluindo-se, apenas, os filiados a algum regime próprio de previdência. ${ }^{210}$

A Constituição estabelece, ainda, a necessidade de equilíbrio financeiro e atuarial, em redação inserida pela reforma constitucional de 1998. Todavia, como vimos anteriormente, isto não implica, necessariamente, na autossustentação da Previdência Social, pois o texto constitucional prevê o financiamento da seguridade social não só por beneficiários e empresas, mas por toda a sociedade por via dos impostos. Nenhuma reforma constitucional conseguiu alterar este elemento de solidariedade da previdência brasileira. $^{211}$

A Previdência Social no país é obrigatoriamente mantida pelo poder público, como nos mostra o texto constitucional e é composta por dois regimes: o Regime Geral da Previdência Social (RGPS), que é mantido pela União e cobre a grande massa dos trabalhadores brasileiros. O RGPS tem como unidade gestora o Instituto Nacional da Seguridade Social (INSS), autarquia vinculada ao Ministério da Previdência Social. A

\footnotetext{
${ }^{209}$ REDI, Maria Fernanda de Medeiros. Fundamentos da Regulação da Previdência Privada no Brasil. Tese de Doutorado em Direito Econômico apresentada na Faculdade de Direito da USP. São Paulo, 2004, p. 138.

${ }^{210}$ IBRAHIM, Fábio Zambitte. Curso de direito previdenciário. 15. ed., rev., amp. e atual. Niterói, RJ: Impetus, 2010, p. 32.

${ }^{211}$ REDI, op. cit., p. 161.
} 
legislação que rege o RGPS são as Leis 8.212/1991 e 8.213/1991 e seus respectivos regulamentos, que definem e instituem as condições dos segurados, dos benefícios, contribuintes e planos de custeio.

Já os Regimes Próprios de Previdência dos Servidores (RPPS) estão previstos na Constituição Federal no art. 40 e são de competência dos entes federados nos três níveis: União, Estados, Municípios e Distrito Federal. Estes entes estão autorizados pela Constituição Federal a adotarem um regime de aposentadoria para os seus servidores titulares de cargos efetivos. Os regimes instituídos devem, como o RGPS, ser de caráter contributivo e solidário. A Constituição incumbiu a União de estabelecer as regras gerais para os RPPS (Lei 9.717/1998), que devem ser seguidos pelos Estados, Municípios e Distrito Federal.

Note-se que os RPPS destinam-se apenas aos servidores públicos strictu sensu, ou seja, àqueles submetidos ao Regime Jurídico Único que cada ente federado estabelece para os servidores da sua Administração Direta, autarquias e fundações públicas. No caso da União, são aqueles regidos pela Lei 8.112/1990, exceto os titulares exclusivos de cargos em comissão (art. 40, $§ 13^{\circ}$ da Constituição). Isso significa que os RPPS não abarcam os empregados públicos (das empresas públicas e sociedades de economia mista), submetidos à CLT e, consequentemente, ao RGPS.

\subsubsection{Previdência Complementar na Constituição de 1998}

A Previdência Complementar ou privada ${ }^{212}$, por sua vez, encontrava previsão constitucional no art. 192, II, como instituições integrantes do sistema financeiro nacional, devendo, como tal, "promover o desenvolvimento equilibrado do País e a servir aos interesses da coletividade" (art. 192, caput). Entretanto, os incisos deste artigo foram revogados pela EC 40/2003.

Originalmente esta era a única previsão constitucional sobre a previdência complementar. Apenas com a Emenda Constitucional $\mathrm{n}^{\circ}$ 20/1998 este regime previdenciário foi incluído na seção que trata da Previdência Social, com a completa alteração do art. 202. Todavia, apesar de estar inserida formalmente na seção sobre Previdência Social, o caput do art. 202 explicita que ela se organizará “de forma

212 Como vimos, "previdência privada" era a expressão utilizada na a lei 6.435/1977, para designar as instituições de previdência sob gestão não-estatal. Todavia, a nomenclatura foi alterada na Lei Complementar 109/2001 para "Previdência Complementar". A Constituição faz uso dos dois termos como sinônimos, sem diferenciá-los. Neste trabalho, utilizaremos "Previdência Complementar", conforme prevê a legislação em vigor. 
autônoma ao regime geral da previdência social", o que é natural, dado que a Previdência Complementar não seguirá os mesmos princípios do RGPS nem mesmo estará sob gestão do INSS.

O caput do art. 202 fala em complementariedade e facultatividade da previdência privada, o que é coerente com a existência de um pilar público básico e obrigatório de previdência. Esta característica, no entanto, não implica em qualquer dependência entre os dois pilares - público e privado. Ou seja, a contribuição realizada a um dos pilares não obriga ou vincula a contribuição ao outro, muito menos a percepção de benefícios pelo regime privado guarda relação com os benefícios do regime geral. Como observa Maria Fernanda Redi:

Assim o caráter complementar atribuído à previdência privada mais condiz com o sentido de que se constitui supletivamente ao regime geral de previdência, mas não concorrentemente com este. Ou seja, o regime de previdência não será organizado de forma a retirar indivíduos ou grupos do âmbito do dever de solidariedade social representado pelo regime geral de previdência social. ${ }^{213}$

A parte que trata da Previdência Complementar na Constituição é menos descritiva e exaustiva que a da Previdência Social. O que é coerente com o fato desta ser uma área mais aberta à livre iniciativa, conforme veremos posteriormente. A Constituição remete à Lei Complementar a regulação do tema (LC 109/2001), porém garante aos participantes da Previdência Complementar os direitos de acesso às informações sobre os seus planos e benefícios, e de participação na gestão das entidades fechadas $\left(\S \S 1^{\circ} \mathrm{e}\right.$ $6^{\circ}$ do art. 202). Ademais, exclui os contratos deste pilar da previdência de qualquer relação trabalhista.

Estabelece, ainda, que o aporte de recursos de entidade da administração direta e indireta só é permitido enquanto patrocinadoras das entidades de previdência complementar (neste caso, estaremos necessariamente falando de entidades fechadas), e, mesmo assim, devendo ser sempre igual ou inferior aos aportes dos participantes. Também remete a Lei Complementar à regulação da relação destas instituições públicas com as entidades fechadas patrocinadas por elas (Lei Complementar 108/2001).

\footnotetext{
${ }^{213}$ REDI, Maria Fernanda de Medeiros. Fundamentos da Regulação da Previdência Privada no Brasil. Tese de Doutorado em Direito Econômico apresentada na Faculdade de Direito da USP. São Paulo, 2004, p. 336.
} 
Originalmente, a Constituição não previa a existência de um regime de Previdência Complementar específico para os servidores públicos submetidos ao RPPS. Apenas com a EC 20/1998, foi incluído o seguinte dispositivo no art. 40 do texto constitucional:

$\S 14$ - A União, os Estados, o Distrito Federal e os Municípios, desde que instituam regime de previdência complementar para os seus respectivos servidores titulares de cargo efetivo, poderão fixar, para o valor das aposentadorias e pensões a serem concedidas pelo regime de que trata este artigo, o limite máximo estabelecido para os benefícios do regime geral de previdência social de que trata o art. 201.

Assim, foi estabelecido um teto de cobertura para o RPPS, igual àquele do RGPS, com a condição de que o poder público crie, através de lei específica, uma Entidade Fechada de Previdência Complementar (EFPC) para os titulares de cargos efetivos. Nova Emenda Constitucional, a EC 47/2005, modificou a redação do $\$ 15^{\circ}$ (que também havia sido inserido na reforma de 1998), para estabelecer que esta entidade fosse de natureza pública e oferecesse planos apenas na modalidade de contribuição definida.

Ou seja, a EFPC dos servidores públicos teria a peculiaridade de ser constituída sob a forma de pessoa jurídica de direito público, compondo, assim, a Administração Pública Indireta; ao contrário das EFPC então existentes, previstas no art. 202 para serem constituídas sob a forma de pessoas jurídicas de direito privado, não-integrantes da Administração Pública, mesmo se patrocinadas por empresas públicas ou sociedades de economia mista. Mantida, contudo, o caráter de facultatividade e complementariedade deste regime de previdência.

Trata-se, portanto, de uma situação sui generis: um regime de previdência complementar, na forma de capitalização e não de repartição, facultativo, e gerido pelo Estado. O fato de integrarem a Administração Pública, a nosso ver, pode aumentar a possibilidade de controle do poder público sobre as decisões deste regime previdenciário, em especial no que diz respeito às possibilidades e alternativas de investimento.

No plano federal, a previdência complementar para os servidores públicos só viria a ser concretizada mais de uma década depois, com a Lei $n^{\circ} 12.618 / 2012$ e o Decreto $n^{\circ}$ 7.808/2012 que, respectivamente, autorizou a criação e criou a Fundação de Previdência Complementar do Servidor Público Federal do Poder Executivo (Funpresp-Exe), sob a 
forma de fundação pública. A perspectiva do Governo Federal é de que em algumas décadas este se transforme no maior fundo de pensão da América Latina. ${ }^{214}$ Em cartilha publicada pelo Ministério da Previdência Social ${ }^{215}$ estão expressos os objetivos de "expansão da poupança interna brasileira e o aumento de investimentos em obras de infraestrutura no país".

\subsubsection{Reformas Constitucionais}

As previsões constitucionais sobre a Previdência Social foram objeto de duas importantes reformas. ${ }^{216}$ Apesar de não serem diretamente objeto desta dissertação, por tratarem principalmente de mudanças no núcleo básico da previdência, estas reformas interessam à nossa investigação por criarem incentivos ao desenvolvimento $\mathrm{e}$ crescimento da previdência privada, com a ampliação dos regimes previdenciários de capitalização. ${ }^{217}$ Estes regimes, conforme demonstrado no capítulo anterior, estão intrinsecamente ligados à forma de acumulação predominantemente na esfera financeira. Não à toa, trata-se de uma reforma semelhante à verificada em países da Europa, da América Latina e nos EUA. ${ }^{218}$

As duas reformas constitucionais aconteceram num lapso temporal de 5 (cinco) anos, com as Emendas Constitucionais 20/1998 e 41/2003, em governos liderados por partidos distintos e que se opõem na luta político-eleitoral brasileira, a saber: o governo de Fernando Henrique Cardoso, do Partido da Social Democracia Brasileira (PSDB), e o governo de Luís Inácio Lula da Silva, do Partido dos Trabalhadores (PT). ${ }^{219}$ Este fato

\footnotetext{
214 Funpresp será maior fundo de pensão da América Latina, diz ministra. Disponível em: <http://memoria.ebc.com.br/agenciabrasil/noticia/2013-02-04/funpresp-sera-maior-fundo-de-pensao-daamerica-latina-diz-ministra>. Acesso em 23.04.2014.

215 MINISTÉRIO DA PREVIDÊNCIA SOCIAL. Conheça mais sobre a Funpresp - Fundação de Previdência Complementar do Servidor Público Federal. Disponível em: <http://www.mpas.gov.br/arquivos/office/3_120229-095948-775.pdf >. Acesso em: 23.04.2014.

216 Todavia, a primeira alteração constitucional de que foi objeto a Previdência Social foi a Emenda Constitucional $\mathrm{n}^{\circ}$ 3, ainda no ano de 1993, que incluiu a participação dos servidores públicos no financiamento do RPPS da União (art. 40, §6º posteriormente modificado pela EC 20/1998).

217 SOUZA, Claudio Ferrer de. As Reformas da Previdência Social: uma análise comparativa dos sistemas de previdência social sob o aspecto das mudanças contemporâneas no atual cenário mundial. In CORREIA, Marcus Orione Gonçalves (coord.) e VILLELA, José Corrêa (org.) Previdência Privada. São Paulo: LTr, 2004, p. 117.

${ }^{218}$ Para uma discussão das experiências internacionais de reforma da previdência, ver: BLACKBURN, Robin. Banking on Death or investing in life: the history and future of pensions. Verso. Nova York, 2002; e REDI, Maria Fernanda de Medeiros. Fundamentos da Regulação da Previdência Privada no Brasil. Tese de Doutorado em Direito Econômico apresentada na Faculdade de Direito da USP. São Paulo, 2004, pp. 137-158.

${ }^{219}$ No caso do Partido dos Trabalhadores, o episódio chegou a ser traumático para boa parte de sua militância dos seus parlamentares, que consideravam a reforma uma traição ao programa historicamente
} 
demonstra convergência programática entre os dois partidos no que diz respeito ao tema. Discutindo os interesses do Partido dos Trabalhadores na mudança constitucional, Francisco de Oliveira ${ }^{220}$ chega a falar no surgimento de uma nova "classe social", emergente da administração dos fundos de pensão e consequente submissão e admoestação pelo capital financeiro.

A primeira reforma abrangente no sistema previdenciário, realizada pela EC 20/1998, reforçou o caráter contributivo da previdência e inseriu no texto constitucional a necessidade da observância do equilíbrio financeiro e atuarial, tanto na previdência dos servidores públicos quanto no regime geral.

No serviço público, a aposentadoria não se daria mais pelo tempo de serviço, mas sim pelo tempo de contribuição. Foram inseridos ainda requisitos mais restritivos quanto a idade, tempo mínimo de contribuição, tempo no serviço público e de cargo efetivo, e foi vedado o acúmulo de percepção de aposentadorias pelo regime próprio dos servidores.

Ao desconstitucionalizar a forma de cálculo das aposentadorias do RGPS, a EC 20/1988 possibilitou a adoção do fator previdenciário ${ }^{221}$, pela Lei 9.876/1999, o que reduziu, em geral, o valor das aposentadorias. Por último, mas não menos importante, a reforma constitucional de 1998 estabeleceu um teto para o pagamento de aposentadorias no RGPS, teto este que poderia ser estendido aos RPPS, desde que criada a entidade correspondente de Previdência Complementar, conforme observamos acima.

Ainda nesta reforma de 1998, foram inseridos os dispositivos relativos à Previdência Complementar (art. 202, que também já analisamos) e cláusulas que visavam a evitar o desvio de utilização dos recursos arrecadados pelas contribuições sobre a folha salarial. $^{222}$

Já a segunda reforma previdenciária, realizada com a EC 41/2003, concentrou-se na mudança das regras para o setor público, com a adoção do limite do RGPS para a

defendido pela agremiação. Três deputados e uma senadora petistas votaram contra a reforma e foram em seguida expulsos do partido: Luciana Genro, Babá, João Fontes e Heloísa Helena.

${ }^{220}$ OLIVEIRA, Francisco de. Crítica à razão dualista / O ornitorrinco. Boitempo Editorial, São Paulo, 2003.

${ }^{221}$ Resultado de cálculo complexo que leva em conta a idade, a expectativa de sobrevida e o tempo de contribuição do segurado a se aposentar. É usado para calcular o salário-de-benefício do contribuinte, conforme Decreto 3.048/1999.

${ }^{222}$ REDI, Maria Fernanda de Medeiros. Fundamentos da Regulação da Previdência Privada no Brasil. Tese de Doutorado em Direito Econômico apresentada na Faculdade de Direito da USP. São Paulo, 2004, pp. 180-181. 
pensão por morte (com acréscimo de $70 \%$ do valor que superasse o limite), desvinculou a revisão dos benefícios dos inativos à remuneração dos servidores ativos, e previu a contribuição dos servidores inativos e dos pensionistas para ajudar no custeio da previdência. Além disso, alterou a previsão da Previdência Complementar dos servidores para um regime com contribuição definida.

Estas reformas foram aprovadas com o argumento de que as mudanças da pirâmide etária, com o envelhecimento da população, aumentariam o desequilíbrio atuarial do núcleo básico da previdência. ${ }^{223}$ As exposições de motivos enviadas pelo Poder Executivo ao Congresso Nacional por ocasião da propositura das Emendas Constitucionais a que nos referimos são pródigas em trazer dados que corroboram esta tese. Também fazem recurso de argumentos distributivos e de combate a privilégios de setores organizados. Vejamos.

O modelo previdenciário vigente é socialmente injusto pois privilegia os segmentos mais organizados e com maior poder de pressão, em detrimento dos segmentos menos favorecidos, que, por sua precária inserção no mercado de trabalho, encontram maiores obstáculos para ter acesso aos benefícios. Além de injusto, ele é inviável, no curto, médio e longo prazos, do ponto de vista financeiro e atuarial. $\mathrm{O}$ desenho de suas regras não obedece à boa técnica, sem a qual, qualquer sistema previdenciário, quer funcione em regime de repartição, quer em regime de capitalização, corre o risco de entrar em colapso. (...) Viabilizar financeiramente a previdência social, tornando-a ao mesmo tempo mais justa, significa assim garantir o pagamento dos benefícios previdenciários às próximas gerações, legando aos nossos filhos e netos um patrimônio construído com o esforço solidário de todos os brasileiros. ${ }^{224}$

Trata-se de avançar no sentido da convergência de regras entre os regimes de previdência atualmente existentes, aplicando-se aos

\footnotetext{
${ }^{223}$ PAULANI, Leda Maria. Seguridade social, regimes previdenciários e padrão de acumulação: uma nota teórica e uma reflexão sobre o Brasil. In FAGNANI, Eduardo; HENRIQUE, Wilnês; e LÚCIO, Clemente Ganz (orgs.). Previdência Social: Como incluir os excluídos. LTr: São Paulo, 2008. Para uma defesa da necessidade de reforma na previdência, propostas e análise de resultados, ver GIAMBIAGI, Fábio; TAFNER, Paulo. (orgs.) Previdência no Brasil: debates dilemas e escolhas. IPEA, Rio de Janeiro, 2007.

${ }^{224}$ Exposição de Motivos da PEC 33/1996 (posteriormente promulgada como EC 20/1998). Diário do Senado Federal, 19 de Julho de 1996, p. 12470.
} 
servidores públicos, no que for possível, requisitos e critérios mais próximos dos exigidos para os trabalhadores do setor privado. Com este vetor, busca-se tornar a Previdência Social mais equânime, socialmente mais justa e viável financeira e atuarialmente para o longo prazo. $^{225}$

O então Ministro da Previdência, Ricardo Berzoini, afirma que a lógica e os objetivos da reforma da previdência do Governo Lula são rigorosamente diferentes das anteriores, por incorporar a dimensão social. Para José Dirceu, então Ministro-Chefe da Casa Civil, a aprovação da reforma também era uma questão de justiça social. ${ }^{226}$ Parece-nos correta a visão pró-distributividade ${ }^{227}$, todavia, não percebemos lógicas diferentes entre as reformas constitucionais aprovadas pelos dois governos. Ambas apontam no sentido de criar critérios mais restritivos para a concessão de benefícios, vinculados mais ao tempo de contribuição que ao tempo de serviço ou à idade, aumentando a participação dos beneficiários no financiamento do regime (tanto no serviço público quanto na iniciativa privada), sendo coerentes com as mudanças no perfil demográfico da população brasileira, ao mesmo tempo em que prezam pela manutenção de um sistema público de garantia de bem-estar social, cobertura universal, com valor mínimo e máximo para os benefícios.

Contudo, os argumentos na linha do equilíbrio atuarial e da adoção de critérios mais distributivos não são os únicos dos que defendem e defenderam as reformas dos anos 1998 e 2003. Para Maria Fernanda Redi:

(...) [a reforma previdenciária] tem por real e principal fundamento a necessidade de geração/fomento de poupança interna com vistas a aumentar os recursos disponíveis, às custas da transferência do risco financeiro para os próprios participantes e seus dependentes. ${ }^{228}$

\footnotetext{
${ }^{225}$ Exposição de motivos da Proposta de Emenda à Constituição posteriormente promulgada como EC 41/2003. Cf. MORHY, Lauro (org.). Reforma da Previdência em questão. Editora UnB, 2003, p. 377413.

${ }^{226}$ Ver BERZOINI, Ricardo. Previdência Social: a mudança com justiça e respeito. In: MORHY, Lauro (org.). Reforma da Previdência em questão. Editora UnB, 2003, pp. 19-26; e SILVA, José Dirceu de Oliveira e. Uma necessidade de justiça social. In MARQUES, Rosa Maria et al. A previdência social no Brasil. Coleção Cadernos da Fundação Perseu Abramo nº 2. Editora Perseu Abramo, São Paulo, 2003, pp. 121-129.

${ }^{227}$ MEDEIROS, Marceli; SOUZA, Pedro H. G. F. de. Previdência dos trabalhadores dos setores público e privado e desigualdade no Brasil. Texto para Discussão no 1876. IPEA. Brasília, 2013.

${ }^{228}$ REDI, Maria Fernanda de Medeiros. Fundamentos da Regulação da Previdência Privada no Brasil. Tese de Doutorado em Direito Econômico apresentada na Faculdade de Direito da USP. São Paulo, 2004, pp. 192-193.
} 
Com efeito, vejamos a opinião de Giambiagi, Oliveira e Beltrão, de 1996:

A taxa de crescimento de longo prazo da economia brasileira dependerá crucialmente de duas variáveis: o déficit fiscal e a taxa de poupança. Níveis baixos (elevados) de déficit público tenderão a estimular (inibir) o investimento, em face da perspectiva de um ambiente macroeconômica o de equilíbrio (desequilíbrio). Paralelamente, a taxa de crescimento esperada será tanto maior (menor) quanto maior (menor) for o coeficiente de poupança doméstica, para uma dada poupança externa. Ambas as questões - o déficit público e a poupança - estarão intrinsecamente associadas ao formato que vier a as sumir o modelo previdenciário do país. ${ }^{229}$

Também Leda Paulani, numa perspectiva mais crítica às reformas, aponta este objetivo:

Uma primeira explicação [para a natureza das mudanças operadas na previdência], quase intuitiva, está relacionada à ampliação do espaço para a operação dos fundos de pensão privados, fechados ou abertos, que daí se deriva. Sobretudo a reforma patrocinada por Lula, ao vincular também os funcionários públicos ao mesmo tipo de imposição a que já haviam sido submetidos os trabalhadores do setor privado, deu grande impulso à criação do mercado de previdência complementar que já estava na agenda política do país desde o início dos anos $1990 .^{230}$

De fato, ao tornar mais desfavorável a relação entre contribuição e benefício nos regimes básicos de previdência, e especialmente ao estabelecer um valor máximo para as aposentadorias e pensões, o Estado empurra os beneficiários à procura de regimes de capitalização que possam oferecer complementos aos valores pagos pelos benefícios do sistema público. Ao se fazer isso, abre-se a oportunidade de crescimento dos volumes de recursos arrecadados pelas entidades de previdência complementar, tanto as abertas quanto as fechadas, e consequentemente, o volume de poupança interna, o que

\footnotetext{
${ }^{229}$ GIAMBIAGI, Fábio; OLIVEIRA, Francisco Eduardo Barreto de; BELTRÃO, Kaizô Iwakami. Alternativas de Reforma da Previdência Social. Revista do BNDES nº 6, dezembro de 1996. Disponível em:

http://www.bndes.gov.br/SiteBNDES/export/sites/default/bndes_pt/Galerias/Arquivos/bf_bancos/e00006 20.pdf >. Acesso em: 24.08.2014.

${ }^{230}$ PAULANI, Leda Maria. Seguridade social, regimes previdenciários e padrão de acumulação: uma nota teórica e uma reflexão sobre o Brasil. In FAGNANI, Eduardo; HENRIQUE, Wilnês; e LÚCIO, Clemente Ganz (orgs.). Previdência Social: Como incluir os excluídos. LTr: São Paulo, p. 29.
} 
representaria uma maior disponibilidade de recursos para aumentar a taxa de investimento na economia brasileira.

Analisaremos no capítulo seguinte de forma mais detida este estímulo. Por hora, cumpre registrar que esta foi uma motivação explícita das reformas previdenciárias, conforme podemos observar abaixo:

Mantendo-se um teto de contribuição e de valor de benefício para a previdência social, busca-se garantir a adesão facultativa do segurado a regime de previdência complementar, organizado segundo critérios fixados em lei. Reconhece-se assim a importância dos fundos complementares de previdência enquanto instrumentos fundamentais, não apenas para assegurar níveis adicionais de proteção, mas também para a geração de poupança de longo prazo e, consequentemente, para o financiamento de projetos de desenvolvimento. ${ }^{231}$

[com a Proposta de Emenda Constitucional] Proporciona-se mais racionalidade e eqüidade ao sistema previdenciário vigente no país, à medida que se desenha uma estrutura igualitária que abrange todos os trabalhadores e, ao mesmo tempo, fortalece um modelo de previdência que tem como corolários, em primeiro lugar a proteção social com base no princípio da solidariedade, bem como a adesão voluntária à previdência complementar, que, ademais, participa da formação de poupança de longo prazo capaz de gerar riquezas e postos de trabalho. $^{232}$

\subsection{Regulação da Previdência Complementar - LC no 109/2001}

Passamos, a partir daqui, a nos concentrar na regulação infraconstitucional dedicada à Previdência Complementar, que se dá, em nível legal, especialmente através de duas Leis Complementares: LC 109/2001 e LC 108/2001. Publicadas concomitantemente, a primeira dispõe sobre as regras gerais da Previdência Complementar, enquanto a segunda diz sobre a relação da União e dos entes federados com as Entidades

\footnotetext{
${ }^{231}$ Exposição de Motivos da PEC 33/1996 (posteriormente promulgada como EC 20/1998). Diário do Senado Federal, 19 de Julho de 1996, p. 12469.

${ }^{232}$ Exposição de motivos da Proposta de Emenda à Constituição posteriormente promulgada como EC 41/2003. Cf. MORHY, Lauro (org.). Reforma da Previdência em questão. Editora UnB, Brasília, 2003, pp. 377-413.
} 
Complementares de Previdência Complementar, de que são patrocinadores exatamente o núcleo da hipótese da nossa pesquisa.

\subsubsection{Fundamentos e objetivos da regulação}

Primeiramente, cumpre situar a Previdência Complementar dentre as categorias da atividade econômica que expusemos anteriormente, isto para entender como se dará a sua regulação. Maria Fernanda Redi ${ }^{233}$ aponta que a Previdência Complementar, por conta da sua autonomia organizacional atribuída pela Constituição, bem como pelo seu caráter de facultatividade e supletividade ${ }^{234}$, constitui-se uma atividade econômica em sentido estrito, estando então num domínio próprio da iniciativa privada, como prevê Eros Grau. ${ }^{235}$

Já discutimos acima que a linha que separa os conceitos de atividade econômica em sentido estrito e o serviço público é tênue, e veremos à frente que o Estado também pode atuar na economia através das entidades de previdência complementar, mas parece-nos claro neste caso o núcleo básico da previdência, universal, obrigatório, solidário e destinado a assegurar um piso de proteção ao cidadão, tem com mais força os contornos de interdependência social de que fala Eros Grau, e, portanto, se encaixa com maior facilidade na noção de serviço público. Também não há que se falar em serviço público sob concessão à iniciativa privada, exatamente pela inexistência dos elementos de universalidade e obrigatoriedade.

Como atividade econômica em sentido estrito, a Previdência Complementar está sob o domínio dos princípios da livre iniciativa, livre concorrência ${ }^{236}$ e liberdade contratual. ${ }^{237}$ Isso explica o pouco grau de detalhamento trazido pelo texto constitucional sobre o tema, e mesmo a forma não taxativa com que a Lei Complementar 109/2001 elenca as modalidades de planos de previdência que serão oferecidos pelas entidades $\left(\operatorname{art}, 7^{\circ}\right.$, parágrafo único).

\footnotetext{
${ }^{233}$ REDI, Maria Fernanda de Medeiros. Fundamentos da Regulação da Previdência Privada no Brasil. Tese de Doutorado em Direito Econômico apresentada na Faculdade de Direito da USP. São Paulo, 2004, p 333-335.

${ }^{234}$ Redi fala em supletividade e não em complementariedade para explicitar que, a adesão à Previdência Complementar não exclui o segurado do Regime Básico de previdência, seja ele o RGPS ou os RPPS.

${ }^{235}$ GRAU, Eros Roberto. Constituição e Serviço Público. In GRAU, Eros Roberto e GUERRA FILHO, Willis Santiago (orgs). Direito Constitucional: estudos em homenagem a Paulo Bonavides. Malheiros: São Paulo, 2003, pp. 101-105.

${ }^{236}$ Mesmo as Entidades Fechadas de Previdência Complementar atuam sob a livre concorrência, afinal o empregado de determinada empresa ou o associado de entidade classista por optar por aderir ou não aos planos oferecidos pela respectiva EFPC, ou mesmo aderir a uma entidade aberta.

${ }^{237}$ REDI, op. cit., p. 336.
} 
A autonomia do regime de Previdência Complementar, previsto no art. 202 da Constituição Federal e reiterado no art. $1^{\circ}$ da LC 109/2001, implica na possibilidade de autogoverno e de separação da sua estrutura normativa do regime básico e público da Previdência Social. ${ }^{238}$ Entretanto, isso não implica em abstenção por parte do Estado, conforme veremos a seguir.

A LC 109/2001 delimita de forma clara as funções do Estado na Previdência Complementar, que, de acordo com os artigos $3^{\circ}$ e $5^{\circ}$, serão de caráter regulatório e fiscalizatório, buscando assegurar direitos e proteção de interesses dos participantes destas entidades. Também cabe ao Estado, através de órgão específico, expedir autorização para a instituição dos planos de benefício (art. 6 da LC 109/2001). Assim, conforma-se uma atividade econômica em sentido estrito, explorada sob o regime de autorização. Trata-se, deste modo, de uma atuação sobre o domínio econômico, justificada pelo relevante interesse coletivo presente na proteção da poupança dos segurados e consequentemente suas expectativas de direito, além de garantir aos participantes dos planos o acesso a informações. Nos termos da LC 109/2001:

Art. $3^{\circ}$ A ação do Estado será exercida com o objetivo de:

I - formular a política de previdência complementar;

II - disciplinar, coordenar e supervisionar as atividades reguladas por esta Lei Complementar, compatibilizando-as com as políticas previdenciária e de desenvolvimento social e econômico-financeiro;

III - determinar padrões mínimos de segurança econômico-financeira e atuarial, com fins específicos de preservar a liquidez, a solvência e o equilíbrio dos planos de benefícios, isoladamente, e de cada entidade de previdência complementar, no conjunto de suas atividades;

IV - assegurar aos participantes e assistidos o pleno acesso às informações relativas à gestão de seus respectivos planos de benefícios;

\footnotetext{
238 GUERZONI, Ana Paula et al. Comentários à Lei Complementar n. 109/01. In CORREIA, Marcus Orione Gonçalves; VILLELA, José Corrêa. (coord. e org.). Previdência Privada: Doutrina e comentários à Lei Complementar n. 109/01. LTr, São Paulo, 2005, pp. 123-127.
} 
V - fiscalizar as entidades de previdência complementar, suas operações e aplicar penalidades; e

VI - proteger os interesses dos participantes e assistidos dos planos de benefícios.

Defende Vania Souto $^{239}$ que a regulação prevista busca aumentar a credibilidade, o profissionalismo e, assim, a possibilidade de expansão da Previdência Complementar. A atuação do Estado teria como fundamento a ideia de solucionar falhas de mercado, notadamente a assimetria de informações. Por meio da ação de fiscalização, o Estado teria o papel, ainda, de criar mecanismos para garantir o equilíbrio atuarial entre o acúmulo das contribuições e os compromissos assumidos pelas entidades (notadamente o pagamento de benefícios):

Procura-se, desse modo, minimizar a possibilidade de falência da empresa, fato que levaria a um desequilíbrio do plano e ao não cumprimento das obrigações pactuadas. A intervenção do Estado deve ainda inibir que informações enganosas sejam passadas ao participante, quando da sua adesão a um plano de capitalização. ${ }^{240}$

Contudo, não são apenas as falhas de mercado que fundamentam a atuação estatal. Neste sentido, aponta Diogo de Sant'Ana ${ }^{241}$ que a regulação deve estar direcionada, por força de previsão constitucional, para dois objetivos, quais sejam: a garantia das reservas para o pagamento dos benefícios, bem como o pagamento dos benefícios conforme contratado, mas não só. A atividade regulatória deve observar, para o autor, os preceitos presentes da Ordem Econômica da Constituição Federal, como a defesa do interesse nacional, a redução das desigualdades, a defesa do consumidor, erradicação da pobreza, dentre outros. Coaduna com esta visão a previsão do art. 3º II, da LC 109/201, segundo o qual a disciplina sobre as atividades reguladas deve ser compatibilizada com “as políticas previdenciária e de desenvolvimento social e econômico-financeiro".

\footnotetext{
239 SOUTO, Vania Lucia Lins. Regulação e a supervisão do sistema de previdência complementar brasileiro: a análise do novo marco regulatório. Dissertação de Mestrado apresentada ao Departamento de Economia da Universidade de Brasília. Brasília, 2001, p. 97-98.

${ }^{240}$ Ibidem, p. 98.

${ }^{241}$ GUERZONI Ana Paula et al. Comentários à Lei Complementar n. 109/01. In CORREIA, Marcus Orione Gonçalves; VILLELA, José Corrêa. (coord. e org.). Previdência Privada: Doutrina e comentários à Lei Complementar n. 109/01. LTr, São Paulo, 2005, pp. 355-357.
} 
Para Maria Fernanda Redi ${ }^{242}$, a regulação da Previdência Complementar historicamente procurou dar higidez ao regime e permitir a sua expansão. Esta expansão, consequentemente, acarretaria na formação de poupança, e seria alcançada através da flexibilidade conferida para a criação e organização dos planos e entidades, além do aumento de credibilidade das instituições com a promoção da transparência.

Nesse sentido, a introdução de mecanismos com vistas à higidez do sistema, ao longo da evolução da regulação da previdência privada no país, acabou por se justificar como instrumento de atração da poupança interna de longo prazo, que se vislumbrava desenvolver através da regulação da atividade de previdência privada. ${ }^{243}$

De fato, na Exposição de Motivos que encaminhou o Projeto de Lei Complementar $\mathrm{n}^{\circ}$ 10/1999 (posteriormente convertida na LC 109/2001), a credibilidade buscada para a Previdência Complementar era vista como um instrumento para o objetivo de política econômica, qual seja, o aumento do nível da poupança interna de longo prazo. Vejamos.

A maior credibilidade do regime de previdência complementar institucionalizará e consolidará uma modalidade de poupança interna pouco explorada e (sic) nosso País - a de perfil de longo prazo - o que facilitará a redução do grau extremado de dependência de capitais externos e voláteis a que nações que ainda não atingiram o nível pleno de desenvolvimento estão sujeitas. Para essa consolidação da poupança de longo prazo, a credibilidade é irmã da transparência da gestão e do pleno acesso de informações aos participantes de entidades de previdência complementar. (...) As entidades de previdência complementar, especialmente as fechadas, poderão tornarse, sob eficaz regulação e atenta fiscalização, atores estratégicos no financiamento doméstico de investimentos de longo prazo e grande porte, destacadamente nas áreas de infra-estrutura e no setor moderno de serviços. ${ }^{244}$ (grifos nossos)

\footnotetext{
${ }^{242}$ REDI, Maria Fernanda de Medeiros. Fundamentos da Regulação da Previdência Privada no Brasil. Tese de Doutorado em Direito Econômico apresentada na Faculdade de Direito da USP. São Paulo, 2004, pp. 318-339.

${ }^{243}$ REDI, Maria Fernanda de Medeiros. Fundamentos da Regulação da Previdência Privada no Brasil. Tese de Doutorado em Direito Econômico apresentada na Faculdade de Direito da USP. São Paulo, 2004, p. 324.

${ }^{244}$ Exposição de Motivos do PLP 10/1999 (posteriormente convertido na LC 109/2001). Diário da Câmara dos Deputados, 17 de março de 1999, p. 9755.
} 
Ao mesmo tempo em que destaca as possibilidades de poupança de longo prazo e consequentemente investimentos em infraestrutura, a Exposição de Motivos do projeto de lei destaca a possibilidade de utilização dos ativos financeiros das entidades de previdência complementar no desenvolvimento do mercado de capitais do país, “diversificando o espectro de produtos financeiros existentes e aprofundando a profissionalização dos recursos humanos das instituições financeiras aqui sediadas". 245

Com isso, conclui Maria Fernanda Redi que o real objetivo da aprovação deste marco legal para a previdência não foi a adoção de uma disciplina forte de proteção do indivíduo contra os riscos sociais, mas, sim, a instrumentalização das entidades de previdência complementar para estes objetivos de política econômica. ${ }^{246}$

\subsubsection{Natureza do vínculo}

O vínculo entre o participante do plano de Previdência Complementar e a entidade que o institui é de natureza privada e contratual ${ }^{247}$. Depende da manifestação de vontade do participante em ingressar nos planos oferecidos. Entretanto, a igualdade dos contratantes não é plena, pois o participante pode apenas decidir pela adesão ou não ao plano de benefícios, não cabendo a discussão de cláusulas contratuais, por exemplo. Trata-se, portanto, de um contrato de adesão ${ }^{248}$ entre a entidade e o participante, o que justifica a ação do Estado na regulação prudencial da Previdência Complementar, bem como a aplicação do Código de Defesa do Consumidor, conforme prevê a Súmula 321 do Superior Tribunal de Justiça.

Trata-se de contrato de trato sucessivo, porque se prolonga no tempo com prestações e contraprestações; aleatório, porque depende de fatos determinados que podem ou não ocorrer ao longo do tempo; e por ser de trato sucessivo, há a possibilidade de alteração unilateral por parte da Entidade de Previdência Complementar ${ }^{249}$. Todavia, o contrato previdenciário se submete a regras cogentes emanadas pela legislação (especialmente a

245 Exposição de Motivos do PLP 10/1999 (posteriormente convertido na LC 109/2001). Diário da Câmara dos Deputados, 17 de março de 1999, p. 9755.

${ }^{246}$ REDI, Maria Fernanda de Medeiros. Fundamentos da Regulação da Previdência Privada no Brasil. Tese de Doutorado em Direito Econômico apresentada na Faculdade de Direito da USP. São Paulo, 2004, p. 329.

${ }^{247}$ IBRAHIM, Fábio Zambitte. Curso de direito previdenciário. 15. ed., rev., amp. e atual. Niterói, RJ: Impetus, 2010, pp. 801-803.

${ }^{248}$ MARTINS, Sérgio Pinto. Direito da Seguridade Social. $29^{\text {a }}$ ed. Editora Atlas, São Paulo, 2009, p. 466.

${ }^{249}$ ALENCAR, Marcele Caroline Maciel de. Defesa do contrato previdenciário das Entidades Fechadas de Previdência Complementar: aspectos jurídicos relevantes e proposições. In PREVIC. $2^{o}$ Prêmio PREVIC de Monografias: previdência complementar fechada. Brasília, 2010, p. 20. 
LC 109/2001 e, no caso daquelas patrocinadas por entes federados ou órgãos da Administração Pública, a LC 108/2001). Assim, as alterações contratuais devem ser aprovadas previamente pelo órgão regulador e o contrato deve submete-se ao órgão fiscalizador do Estado.

Nas Entidades Fechadas de Previdência Complementar subiste um caráter de mutualismo do contrato, o que significa que o plano de benefícios oferecido pela entidade é um "patrimônio coletivo, em que cada participante possui uma fração ideal, porém quantificável monetariamente". 250

\subsubsection{Forma das Entidades de Previdência Complementar}

Como visto anteriormente, existem dois tipos de entidade de Previdência Complementar, as abertas e as fechadas, ambas com previsão na Lei Complementar 109/2001.

As Entidades Abertas de Previdência Complementar (EAPC) (arts. 36 a 40 da LC 109/2001) devem-se constituir, obrigatoriamente, sob a forma de sociedade anônima (art. 36). Como tal, estas entidades de previdência visam ao lucro com a sua atividade econômica. Visam a garantir cobertura previdenciária a quem não possa ou não queira aderir a um fundo fechado, dado que estes são de acesso restrito, como veremos abaixo. As EAPC podem oferecer benefícios previdenciários de forma continuada ou em pagamento único. Esta característica, em conjunto com o fato de a Previdência Complementar aberta ser fomentada individualmente, sem participação dos empregadores, acentua o caráter de investimento destes planos. ${ }^{251}$

Já as Entidades Fechadas de Previdência Complementar (EFPC) (arts. 31 a 35 da LC 109/2001) são aquelas acessíveis apenas a determinado grupo de pessoas, conforme dispõe a lei. Elas podem ser restritas "aos empregados de uma empresa ou grupo de empresas e aos servidores da União, dos Estados, do Distrito Federal e dos Municípios" ou aos "associados ou membros de pessoas jurídicas de caráter profissional, classista ou setorial”. No primeiro caso, as empresas, grupo de empresas ou o ente federado será

\footnotetext{
${ }^{250}$ ALENCAR, Marcele Caroline Maciel de. Defesa do contrato previdenciário das Entidades Fechadas de Previdência Complementar: aspectos jurídicos relevantes e proposições. In PREVIC. $2^{o}$ Prêmio PREVIC de Monografias: previdência complementar fechada. Brasília, 2010, p. 22.

${ }^{251}$ NASCIMENTO, Sergio. Entidades Abertas de Previdência Privada. In CORREIA, Marcus Orione Gonçalves (coord.) e VILLELA, José Corrêa (org.) Previdência Privada. São Paulo: LTr, 2004, pp. 5758.
} 
denominado de patrocinador, enquanto as associações classistas e profissionais serão denominadas instituidoras.

As EFPC serão constituídas sob a forma de associação ou fundação ${ }^{252}$ da sociedade civil, em ambos os casos sem fins lucrativos. Numa Entidade Fechada de Previdência Complementar, eventual resultado superavitário destina-se à formação de reserva de contingência para cobrir possíveis desequilíbrios futuros, e caso o superávit seja persistente, pode ser revertido em aumento no valor dos benefícios pagos, o que decorre da característica de mutualismo que expusemos anteriormente (art. 20 da LC 109/2001). ${ }^{253}$ Por seu turno, o mutualismo implica também em uma "socialização dos riscos" entre patrocinadores, participantes e assistidos, que devem arcar com o equacionamento de eventual resultado deficitário, podendo, entretanto, buscar indenização através de ação regressiva contra os administradores da entidade (art. 21).

As EFPC também têm como regime obrigatório a capitalização. Aqui, ao contrário das entidades abertas, é facultado ao empregador ou à associação a contribuição para o custeio do plano. Entretanto, a empresa ou associação não responde pelos riscos do fundo. Os fundos de pensão têm sua estrutura mínima de órgãos de direção prevista em lei, neles participando os empregadores (patrocinadores) e empregados (beneficiários).

Os planos de benefícios oferecidos pelas entidades, fechadas ou abertas, devem atender a padrões mínimos estabelecidos pelo órgão regulador e fiscalizador e podem ser de três modalidades: benefício definido, contribuição definida e contribuição variável, além de outras modalidades que "reflitam a evolução técnica e possibilitem flexibilidade ao regime de previdência complementar" (art. $7^{\circ}$, parágrafo único). Todavia, para as EFPC, a Lei estabelece que elas só poderão ofertar planos na modalidade contribuição definida (art. $\left.31 \S 2^{\circ}, \mathrm{I}\right)$.

A Resolução no 16, de 22 de novembro de 2005, do Conselho de Gestão da Previdência Complementar $(\mathrm{CGPC})^{254}$, traz a definição destas três modalidades de plano de

\footnotetext{
${ }^{252}$ Com a exceção, já observada, das entidades patrocinadas por entes federados, que serão constituídas como pessoas jurídicas de direito público.

${ }^{253}$ ALENCAR, Marcele Caroline Maciel de. Defesa do contrato previdenciário das Entidades Fechadas de Previdência Complementar: aspectos jurídicos relevantes e proposições. In PREVIC. $2^{o}$ Prêmio PREVIC de Monografias: previdência complementar fechada. Brasília, 2010, p. 19.

${ }^{254}$ O CGPC, com atribuições previstas no Decreto $n^{\circ} 4.678 / 2003$, era órgão integrante da estrutura do Ministério da Previdência Social e exerceu o papel de órgão regulador das atividades das Entidades Fechadas de Previdência Complementar, até a publicação do Decreto no 7.123/2010, que criou o Conselho
} 
benefícios. O plano de benefício definido é aquele "cujos benefícios programados têm seu valor ou nível previamente estabelecidos, sendo o custeio determinado atuarialmente, de forma a assegurar sua concessão e manutenção" (art. $\left.2^{\circ}\right)$.

Já o plano de contribuição definida, o único que pode ser oferecido pelas EFPC, é:

aquele cujos benefícios programados têm seu valor permanentemente ajustado ao saldo de conta mantido em favor do participante, inclusive na fase de percepção de benefícios, considerando o resultado líquido de sua aplicação, os valores aportados e os benefícios pagos. (art. $3^{\circ}$ )

Ou seja, aqui, a contribuição do participante tem valor fixo e o benefício a ser percebido submete-se às variações da remuneração do capital do fundo. Por último, temos o plano de contribuição variável, "aquele cujos benefícios programados apresentem a conjugação das características das modalidades de contribuição definida e benefício definido" (art. $4^{\circ}$ ). Geralmente, estes planos de contribuição variável funcionam como planos de contribuição definida na fase de acumulação e de benefício definido na fase de pagamento. ${ }^{255}$

\subsubsection{Governança das Entidades de Previdência Complementar}

No que se refere à estrutura de governança das entidades, a LC 109/2001 confere tratamento bem diferente às entidades abertas e fechadas.

Quanto às abertas, não estabeleceu qualquer critério de formação ou composição de suas instâncias diretoras e/ou fiscalizadoras. ${ }^{256}$ Delegou ao órgão regulador o estabelecimento dos critérios de investidura e posse nos cargos de direção, com a ressalva de que estes não podem ter sofrido condenação criminal transitada em julgado ou penalidade administrativa como servidor público ou por infração contra a seguridade social (art. 37, I). De todo modo, a lei estabelece que a constituição e o funcionamento dessas entidades, bem como as suas disposições estatutárias e respectivas alterações devem passar por aprovação prévia do órgão fiscalizador (art. 38, I).

Nacional de Previdência Complementar(CNPC) e a Câmara de Recursos da Previdência Complementar (CRPC).

255 AMARAL, Felipe Vilhena Antunes. Desafios na gestão dos ativos financeiros e passivos previdenciários nos fundos de pensão. In PREVIC. $3^{\circ}$ Prêmio PREVIC de Monografias: previdência complementar fechada. Brasília, 2011, p. 64.

${ }^{256}$ Todavia, enquanto Sociedades Anônimas, submetem-se às regras de governança aplicadas a estas empresas (Lei n ${ }^{\circ}$ 6.404/1976). 
As entidades fechadas submetem-se aos mesmos requisitos de "ficha limpa" para os pretendentes a cargos de direção (art. $35,3^{\circ}$, II e III), bem como de autorização prévia do órgão fiscalizador sua constituição e aplicação de seus estatutos (art. 33, I). Todavia, a LC 109/2001 prevê uma estrutura mínima de governança para as EFPC, composto por três órgãos: conselho deliberativo, conselho fiscal e diretoria-executiva (art. 35), assegurando aos participantes e assistidos pelo plano um mínimo de um terço dos assentos nos conselhos deliberativo e fiscal. Esta última regra estende para todas as EFPC o direito que a Constituição assegurou aos participantes de fundos de pensão patrocinados por entes federados e entidades da Administração Pública (art. 202, $\S 6^{\circ}$ da Constituição Federal).

Os membros da diretoria-executiva da EFPC devem, além de cumprir os requisitos relativos aos antecedentes, ter formação mínima de nível superior (art. 35, §4º ). Dentre os integrantes da diretoria-executiva, será escolhido o responsável pelas aplicações dos recursos arrecadados, devendo, entretanto, os demais diretores responder solidariamente por eventuais prejuízos causados (art. $35, \S \S 5^{\circ}$ e $6^{\circ}$ ). Tanto os membros da diretoriaexecutiva quanto dos conselhos deliberativo e fiscal poderão perceber remuneração (art. $35, \S 7^{\circ}$ ). Quanto à administração dos recursos arrecadados, determina a LC 109/2001 que as EFPC devem terceirizar a gestão, através da contratação de instituição financeira especializada e credenciada no órgão regulador competente (art. $\left.31 \S 2^{\circ}, \mathrm{I}\right)$.

Fica clara, com estas regras, a intenção do legislador em: i) profissionalizar a gestão das EFPC com a permissão para remuneração dos dirigentes, exigência de que tenham nível superior, e exigência de contratação de instituição especializada para gerir os recursos; ii) proteger a entidade da má-administração através da responsabilidade solidária pelos prejuízos, e; iii) garantir a participação dos assistidos nas decisões do plano e na sua fiscalização.

As EFPC, objeto desta dissertação, que são aquelas patrocinadas por empresas estatais, têm regras específicas para a sua estrutura de governança, como veremos à frente, estabelecidas pela Lei Complementar $n^{\circ}$ 108/2001, aplicando-se subsidiariamente a LC 109/2001 (conforme previsão do art. $2^{\circ}$ da LC 108/2001). 


\subsubsection{Proteção da higidez da Previdência Complementar}

A LC 109/2001, seguindo a linha de conferir equilíbrio atuarial para a segurança dos participantes e credibilidade para a expansão do regime de Previdência Complementar, estabelece diversos mecanismos prudenciais para a proteção da higidez das Entidades de Previdência Complementar. Já expusemos alguns exemplos, como a profissionalização dos gestores e a responsabilização solidária dos diretoresexecutivos, além da concorrência entre patrocinadores/instituidores, participantes e assistidos em eventual resultado deficitário das EFPC. Vale explicitar outros mecanismos previstos na legislação, que veremos a seguir.

O primeiro deles é a necessidade de aprovação prévia e específica de cada plano de benefícios pelo órgão regulador e fiscalizador (art. $6^{\circ}$ ), tanto nas entidades abertas quanto nas fechadas. Esta aprovação prévia justifica-se pela necessidade de assegurar transparência, solvência, liquidez e equilíbrio econômico-financeiro e atuarial aos planos $\left(\operatorname{art.} 7^{\circ}\right)$.

Igualmente importante é a imposição às entidades de constituírem reservas técnicas, provisões e fundos (art. $9^{\circ}$ ), para a cobertura das incertezas inerentes ao mercado financeiro, combinada com a possibilidade de contratação de resseguros conforme determinação dos órgãos reguladores e fiscalizadores (art. 11). Explica Maria Fernanda Redi que o resseguro é um contrato entre seguradores, pelo qual um deles se obriga perante o outro a cobrir, ao menos em parte, um risco que o último já assumiu diretamente perante o segurado. ${ }^{257}$ Ainda, a lei estabelece competência, de um lado, para o órgão regulador a criação regras gerais atuariais e contábeis e, de outro, para o órgão fiscalizador, o controle da observância dessas regras pelas entidades abertas e fechadas (arts. 23 e 29, I).

Para as Entidades Fechadas de Previdência Complementar, a LC 109/2001 estabelece ainda algumas regras específicas (que não se aplicam às EAPC) para a preservação de sua higidez:

i) Elaboração de plano de custeio, com periodicidade mínima anual (art. 18, caput);

\footnotetext{
${ }^{257}$ REDI, Maria Fernanda de Medeiros. Fundamentos da Regulação da Previdência Privada no Brasil. Tese de Doutorado em Direito Econômico apresentada na Faculdade de Direito da USP. São Paulo, 2004, p. 346.
} 
ii) Imposição de que as reservas técnicas, provisões e fundos deverão atender permanentemente à cobertura integral dos compromissos assumidos, em cada plano de benefícios $\left(\operatorname{art.} 18, \S 3^{\circ}\right)$;

iii) Dever de manter a sua contabilidade atualizada (art. 23, caput), bem como de encaminhar ao final de cada exercício as demonstrações contábeis e avaliações atuariais de cada plano de benefícios (art. 22);

iv) Submissão de suas contas a auditoria externa independente (art. 23, caput).

\subsection{6 Órgãos Reguladores e Fiscalizadores}

A Lei Complementar 109/2001 prevê em seu art. 5ª edição de uma lei específica para detalhar os atores e as competências das atividades de "normatização, coordenação, supervisão, fiscalização e controle das atividades das entidades de previdência complementar". Já em suas disposições gerais, prevê que, até que houvesse a aprovação da lei, as funções de órgão regulador seriam exercidas pelo Conselho de Gestão da Previdência Complementar (CGPC), no caso das entidades fechadas, e pelo Conselho Nacional de Seguros Privados (CNSP), no caso das abertas. Já a atividade de fiscalização seria exercida pela Secretaria de Previdência Complementar (SPC), para as entidades fechadas, e pela Superintendência de Seguros Privados (SUSEP) para as entidades abertas. Assim, a lei consagrou um modelo no qual as atividades de regulação e fiscalização para as entidades fechadas estaria a cargo do antigo Ministério da Previdência e Assistência Social (MPAS), e do Ministério da Fazenda no caso das entidades abertas.

De fato, foi este o modelo que vigorou até a Lei $\mathrm{n}^{\circ} 12.154 / 2009$, que criou a Superintendência Nacional de Previdência Complementar (Previc), autarquia vinculada ao Ministério da Previdência Social, e o Decreto $n^{\text {o }} 7.123 / 2010$, que dispôs sobre a organização e funcionamento do Conselho Nacional de Previdência Complementar (CNPC), dentro da estrutura organizacional do mesmo Ministério. Com estes diplomas legais, o CNPC e a Previc passaram a ser, respectivamente, os órgãos regulador e fiscalizador das Entidades Fechadas de Previdência Complementar (EFPC). Manteve-se a diferenciação, na regulação e fiscalização, entre as entidades abertas e fechadas de 
Previdência Complementar, sendo aquelas submetidas aos mesmos órgãos que atuam sobre as demais instituições securitárias.

Quanto às aplicações das EFPC, a LC 109/2001, designou o Conselho Monetário Nacional $(\mathrm{CMN})$ como órgão regulador $\left(\operatorname{art.} 9^{\circ}, \S^{\circ}\right)$. Hoje, esta regulação é feita através da Resolução no 3.792/2009 deste órgão, que será esmiuçada adiante.

O Conselho Nacional de Previdência Complementar (CNPC) é uma instância colegiada integrante do Ministério da Previdência Social e, portanto, parte da Administração Pública Direta. O CNPC é composto por 8 (oito) membros com mandato de 2 (dois) anos, permitida uma recondução, além de seu presidente, que será obrigatoriamente o Ministro de Estado da Previdência Social. O presidente do Conselho exerce o direito de voto qualificado em caso de empate. Dos 8 (oito) membros do CNPC, 2 (três) serão indicados pelo Ministério da Previdência Social, 1 (um) pelo Ministério da Fazenda, 1 (um) do Ministério do Planejamento, 1 (um) pela Casa Civil da Presidência da República, além de representantes dos patrocinadores/instituidores, das EPFC e dos participantes/assistidos.

Já a Superintendência Nacional de Previdência Complementar (Previc) é uma autarquia especial vinculada ao Ministério da Previdência Social. Portanto, é uma entidade da Administração Pública Indireta, dotada de autonomia administrativa, quadro pessoal próprio e orçamento proveniente da Taxa de Fiscalização e Controle da Previdência Complementar (TAFIC), paga quadrimestralmente pelas EFPC. Os diretores da autarquia são indicados pelo Ministro da Previdência Social e nomeados pelo Presidente da República. Estes diretores não possuem mandato, ou seja, podem ser nomeados e/ou exonerados a qualquer tempo.

A Previc tem como suas atribuições (art. $2^{\circ}$ da Lei 12.154/2010):

i) Fiscalizar as atividades e operações das EFPC;

ii) Apurar e julgar infrações e aplicar as penalidades cabíveis;

iii) Expedir instruções para aplicação das normas do setor, de acordo com o CNPC;

iv) Autorizar:

a. Constituição e funcionamento das EFPC, bem como aplicação dos estatutos e regulamentos; 
b. Operações de fusão, aquisição, incorporação e outras formas de reorganização societária das EFPC;

c. Celebração de convênios e termos de adesão por patrocinadores e instituidores, bem como as retiradas por eles realizadas;

d. As transferências de patrocínio, grupos de participantes e assistidos, planos de benefícios e reservas entre EFPC;

v) Harmonizar as atividades das EFPC com as normas e políticas estabelecidas para o segmento;

vi) Decretar intervenção e liquidação extrajudicial nas EFPC;

vii) Nomear administrador especial para as EFPC, podendo atribuir poderes de intervenção e liquidação extrajudicial;

viii) Promover a mediação e conciliação entre EFPC ou entre estas e seus participantes, assistidos, instituidores ou patrocinadores.

A Lei 12.154/2010 prevê, ainda, a existência da Câmara de Recursos da Previdência Complementar (CRPC), instância colegiada integrante do Ministério da Previdência Social, como instância recursal das decisões proferidas pela diretoria da Previc, especialmente nos processos administrativos para apurar infrações e nas impugnações dos lançamentos tributários da TAFIC (art. 15). A CRPC tem composição de 7 (sete) membros, sendo 4 (quatro) servidores concursados do Ministério da Previdência Social, e os demais indicados por patrocinadores/instituidores, pelas EFPC e pelos participantes/assistidos.

\subsection{Estrutura das EFPC patrocinadas por empresas estatais}

Aprovada junto com a LC 109/2001, a Lei Complementar $n^{\circ} 108 / 201$ visa a regular a relação entre os entes federados, entidades da Administração Indireta e suas respectivas Entidades Fechadas de Previdência Complementar. Isso inclui as EFPC patrocinadas pelas empresas públicas e sociedades de economia mista do Governo Federal, que são objeto deste trabalho.

A referida lei trata fundamentalmente de três aspectos das EFPC patrocinadas pelo poder público: i) planos de benefícios (arts. $3^{\circ}$ a $7^{\circ}$ ); ii) estrutura e governança (arts. $8^{\circ}$ a 23), e; iii) fiscalização. Quanto aos planos de benefícios, a lei estabelece carência mínima, regras para a concessão e reajuste de benefícios, veda o aporte de recursos por parte do poder público a não ser na condição de patrocinador (mesma disposição da 
Constituição Federal no seu art. 202, $\S 3^{\circ}$ ), e estabelece regras de fiscalização para estes planos.

No que se refere à fiscalização das EFPC, a lei atribui competência aos mesmos órgãos reguladores e fiscalizadores das demais EFPC (conforme as regras da LC 109/2001). Entretanto, como diferenciação importante, impõe ao poder público a responsabilidade de fiscalizar e supervisionar as entidades que patrocina, inclusive encaminhando o resultado da supervisão e fiscalização aos órgãos reguladores e fiscalizadores (art. 25 da LC 108/2001).

Para a nossa pesquisa, que testa a hipótese de atuação do Estado no domínio econômico através destas entidades, é especialmente importante analisarmos a forma que a lei estabeleceu para a governança das EFPC, para tentarmos compreender qual o espaço que ocupa o poder público, nas entidades que patrocina, para a tomada de decisão, especialmente quanto aos investimentos. Vejamos, então, as regras relativas à governança das EFPC.

São três as instâncias de governança previstas na LC 108/2001: i) Conselho Deliberativo; ii) Conselho Fiscal, e; iii) Diretoria Executiva. O Conselho Deliberativo é o órgão máximo da EFPC, com as principais atribuições relativas à administração da entidade e à aplicação de recursos.

Art. 13. Ao conselho deliberativo compete a definição das seguintes matérias:

I - política geral de administração da entidade e de seus planos de benefícios;

II - alteração de estatuto e regulamentos dos planos de benefícios, bem como a implantação e a extinção deles e a retirada de patrocinador;

III - gestão de investimentos e plano de aplicação de recursos;

IV - autorizar investimentos que envolvam valores iguais ou superiores a cinco por cento dos recursos garantidores; 
V - contratação de auditor independente atuário e avaliador de gestão, observadas as disposições regulamentares aplicáveis;

VI - nomeação e exoneração dos membros da diretoria-executiva; e

VII - exame, em grau de recurso, das decisões da diretoria-executiva. (grifos nossos)

O Conselho Deliberativo deve ser formado por, no máximo, seis membros, e deverá ter composição paritária entre representantes dos patrocinadores (ou seja, o ente público ou empresa estatal), por um lado, e de participantes e assistidos, por outro (art.11, caput). O presidente do conselho deverá ser indicado pelos patrocinadores e terá voto de qualidade. A LC 108/2001 prevê eleição direta dentre participantes e assistidos para a escolha dos representantes $\left(\operatorname{art} .11, \S 1^{\circ}\right.$ ). Todavia, a própria legislação prevê a possibilidade de flexibilização da paridade entre participantes, desde que seja respeitado o número máximo de membros para a composição do conselho e que as regras sejam submetidas à aprovação e autorizadas pelo órgão regulador e fiscalizador $\left(\operatorname{art} .11, \S 2^{\circ}\right.$ ). A lei dispõe, ainda, que os conselheiros terão mandato fixo de quatro anos com garantia de estabilidade, permitida uma recondução (art.12, caput). A estabilidade no cargo só poderá ser interrompida pela abertura de processo disciplinar $\left(\operatorname{art.} 12, \S \S 1^{\circ}\right.$ a $3^{\circ}$ ).

O Conselho Fiscal, por sua vez, também tem previsão de paridade na composição e número máximo de quatro membros. Todavia, aqui a indicação do presidente e, por consequência, o voto de qualidade, caberá aos participantes e assistidos da EFPC (art.15, caput). A LC 108/2001 traz a mesma previsão de flexibilização na composição do Conselho Fiscal, caso haja previsão estatutária e caso seja submetido à aprovação dos órgãos fiscalizador e regulador (art.15, parágrafo único). Os conselheiros também terão mandatos de quatro anos, permitida uma recondução (art.16).

Já a Diretoria-Executiva é o órgão responsável pela administração da entidade, a partir das diretrizes estabelecidas pelo Conselho Deliberativo (art.19), sendo composta por, no máximo, seis membros (art.19 $\left.\$ 1^{\circ}\right)$. A lei deixa a cargo do estatuto da EFPC as

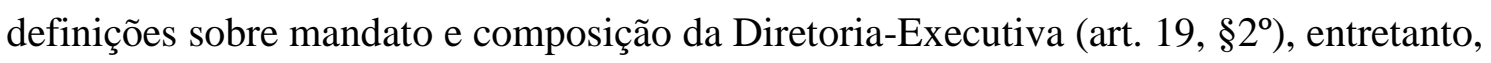
elenca requisitos mínimos para os diretores: 
Art. 20. Os membros da diretoria-executiva deverão atender aos seguintes requisitos mínimos:

I - comprovada experiência no exercício de atividade na área financeira, administrativa, contábil, jurídica, de fiscalização, atuarial ou de auditoria;

II - não ter sofrido condenação criminal transitada em julgado;

III - não ter sofrido penalidade administrativa por infração da legislação da seguridade social, inclusive da previdência complementar ou como servidor público; e

IV - ter formação de nível superior.

Aos membros do Conselho Fiscal e do Conselho Deliberativo, também se aplicam os requisitos acima, com exceção da formação de nível superior (art.18). Observa-se que os requisitos para os conselheiros das entidades patrocinadas pelo poder público são os mesmos elencados no art.35 da Lei 109/2001 para as demais EFPC.

A lei veda aos membros da Diretoria-Executiva o exercício de atividade simultânea no patrocinador, bem como a prestação de serviços a outras instituições financeiras e o exercício simultâneo de atribuições nos Conselhos Fiscal ou Deliberativo (art.22). Também é estabelecida a necessidade de uma quarentena para o diretor da entidade, que se aplica igualmente a outras instituições financeiras, entretanto, não veda a prestação de serviços ou a assunção de cargos na Administração Pública (art.23).

\subsection{Diretrizes para as aplicações: Resolução CMN n 3.792/2009}

O Conselho Monetário Nacional $(\mathrm{CMN})$ é o órgão máximo do Sistema Financeiro Nacional, e foi criado pela Lei $n^{\circ} 4.595 / 1964$. A sua composição atual é determinada pela Lei no 9.069/1994, e é formada pelo Presidente do Banco Central, pelo Ministro do Planejamento, Orçamento e Gestão, além do Ministro da Fazenda, que o preside (art. $8^{\circ}$ ).

De acordo com o art. $3^{\circ}$ da Lei no 4.595/1964, a atuação do CMN tem como objetivo:

I - Adaptar o volume dos meios de pagamento às reais necessidades da economia nacional e seu processo de desenvolvimento; 
II - Regular o valor interno da moeda, para tanto prevenindo ou corrigindo os surtos inflacionários ou deflacionários de origem interna ou externa, as depressões econômicas e outros desequilíbrios oriundos de fenômenos conjunturais;

III - Regular o valor externo da moeda e o equilíbrio no balanço de pagamento do País, tendo em vista a melhor utilização dos recursos em moeda estrangeira;

IV - Orientar a aplicação dos recursos das instituições financeiras, quer públicas, quer privadas; tendo em vista propiciar, nas diferentes regiões do País, condições favoráveis ao desenvolvimento harmônico da economia nacional;

V - Propiciar o aperfeiçoamento das instituições e dos instrumentos financeiros, com vistas à maior eficiência do sistema de pagamentos e de mobilização de recursos;

\section{$\underline{\text { VI - Zelar pela liquidez e solvência das instituições financeiras; }}$}

VII - Coordenar as políticas monetária, creditícia, orçamentária, fiscal e da dívida pública, interna e externa. [grifos nossos]

Desta forma, além de competências de politica monetária, relativas ao controle dos meios de pagamento e regulação do valor da moeda (estabilidade monetária), o CMN tem atribuições de regular as instituições do Sistema Financeiro Nacional, por meio da coordenação das aplicações dessas instituições e de zelar pela sua liquidez e solvência. É justamente nesta última linha de atribuições que se insere a atuação do CMN como órgão regulador da Previdência Complementar.

Vimos anteriormente que a LC 109/2001 reserva ao Conselho Monetário Nacional a atribuição de estabelecer diretrizes para a "aplicação dos recursos correspondentes às reservas, às provisões e aos fundos" constituídos pelas entidades de previdência complementar, sejam elas abertas ou fechadas $\left(\operatorname{art.} 9^{\circ}, \S 1^{\circ}\right)$. Assim, o CMN tem um papel importante no desenho institucional da Previdência Complementar brasileira, especialmente no que diz respeito à política de investimento das entidades. 
No período anterior à LC 109/2001, quando da vigência da Lei 6.435/1997, também competia ao CMN a regulação das diretrizes dos investimentos das entidades, competência que era exercida por meio das Resoluções emanadas do referido Conselho $^{258}$. Inicialmente, eram previstos limites mínimos e máximos para cada classe de ativos. Os limites mínimos aplicavam-se aos títulos públicos federais e às ações de empresas e imóveis $^{259}$. Todavia, a partir da Resolução 2.109/1994, o CMN passou a prever apenas limites máximos para cada categoria de ativo.

Para Paixão, Pinheiro e Chedeak $^{260}$, a imposição de limites mínimos visava ao desenvolvimento e fortalecimento do mercado de capitais brasileiro. Entretanto, gerava, em muitos casos, distorções alocativas que não otimizavam a relação entre risco e retorno dos investimentos. Outra abordagem ${ }^{261}$ entende que a regulamentação visava direcionar os recursos das EFPC ao financiamento da dívida pública.

Esta mudança nas diretrizes (abolição dos limites mímimos) foi elevada a nível legal pela LC 109/2001, que, em seu art. $9^{\circ}$, $2^{\circ}$, a LC 109/2001, veda o estabelecimento de limites mínimos para as aplicações em determinados tipos de ativos, ou a existência de aplicações compulsórias. O limite mínimo poderia ser útil como mais um instrumento de garantia do valor do patrimônio das EAPC e EFPC e consequentemente dos benefícios a serem percebidos pelos assistidos, caso a escolha regulatória determinasse a aplicação em ativos considerados mais conservadores, por exemplo. De outro lado, também poderia constituir um instrumento para o direcionamento da poupança arrecadada para o estímulo de setores da economia. Para Maria Fernanda Redi, a vedação estabelecida na lei:

(...) mitiga os possíveis efeitos do aumento do mercado de previdência complementar na aplicação do volume de recursos que administra em investimentos considerados de interesse público. Mostra-se, assim, uma certa esquizofrenia do modelo regulatório brasileiro atual, pois

\footnotetext{
258 Ver Resoluções CMN 460/1978; 729/1982; 794/1983; 964/1984; 1.025/1985; 1.148/1986; $1.362 / 1987 ; 1.612 / 1989 ; 2.038 / 1993 ; 2.109 / 1994 ; 2.324 / 1996 ; 2.720 / 2000 ; 2.829 / 2001 ; 3.121 / 2003$, e; $3.792 / 2009$.

${ }^{259}$ Cf. Resolução 460/1978 do CMN.

${ }^{260}$ PAIXÃO, Leonardo André; PINHEIRO, Ricardo Pena; CHEDEAK, José Carlos Sampaio. Regulação dos investimentos nos fundos de pensão: evolução histórica, tendências recentes e desafios regulatórios. In Revista de Previdência, n. ${ }^{\circ} 3$. Rio de Janeiro: Faculdade de Direito / UERJ, outubro de 2005, p. 35-53. ${ }^{261}$ INSTITUTO DE PESQUISA ECONOMICA APLICADA. Estado, instituições e democracia: desenvolvimento. Livro 9, Volume 3. Ipea, Brasília, 2010, p. 650.
} 
deixou de utilizar instrumento apto às próprias finalidades regulatórias do regime de previdência privada. ${ }^{262}$

Desta forma, o Conselho Monetário Nacional terá a sua atuação restrita ao estabelecimento de limites máximos para a aplicação de recursos. No caso das Entidades Fechadas, esta regulação é dada pela Resolução no 3.792/2009.

A Resolução 3.792/2009 classifica em 6 (seis) os segmentos de aplicações dos recursos das EFPC (art. 17). São eles: i) renda fixa; ii) renda variável; iii) investimentos estruturados; iv) investimentos no exterior; v) imóveis, e; vi) operações com participantes. Os investimentos em renda fixa (art.18) são principalmente a compra de títulos da dívida pública (dívida mobiliária da União, estados, distrito federal e municípios), depósitos em poupança, títulos emitidos por companhias abertas, dentre outros. Já os investimentos em renda variável (art. 19) são as ações de companhias abertas, fundos compostos de ações de companhias abertas negociadas na bolsa de valores, títulos de Sociedades de Propósito Específico (SPE), debêntures e os Certificados de Potencial Adicional de Construção (CEPAC), dentre outros.

A resolução entende como investimento estruturado (art. 20) as cotas de fundo de investimento em empresas emergentes, cotas de fundo de investimento imobiliário, e fundos de investimento classificado como multimercado, conforme legislação da Companhia de Valores Mobiliários (CVM). Os investimentos no exterior (art. 21), por sua vez, incluem os ativos emitidos no exterior de fundos constituídos no Brasil, os fundos de investimento em dívida externa, e as cotas de fundos que seguem índices do exterior negociadas em bolsas brasileiras, além das empresas estrangeiras sediadas no Mercosul. As operações com imóveis (art. 22) incluem empreendimentos imobiliários e aluguel, entretanto não incluem os fundos imobiliários, classificados como investimentos estruturados, conforme verificamos, nem as operações com os CEPAC, classificados como renda variável. Já as operações com os participantes (art. 23) incluem basicamente as operações de empréstimo e financiamentos imobiliários realizados pelas EFPC com seus participantes e assistidos.

A resolução estabelece que todas as operações com os ativos das EFPC devem seguir as normas emanadas pelo Banco Central e pela CVM (art. 25), e que aquelas que

\footnotetext{
${ }^{262}$ REDI, Maria Fernanda de Medeiros. Fundamentos da Regulação da Previdência Privada no Brasil. Tese de Doutorado em Direito Econômico apresentada na Faculdade de Direito da USP. São Paulo, 2004, pp. 330-331.
} 
envolvem determinados ativos de renda fixa ou renda variável devem passar previamente por análises de risco (art. 30). A resolução estabelece ainda regras específicas de governança para as Sociedades de Propósito Específico pertencentes à carteira das EFPC, bem como uma análise da viabilidade econômica e financeira desses projetos pelas EFPC, que deverá ser realizada previamente à realização das operações (arts.31 e 32).

Posteriormente a estas considerações, a resolução passa a tratar dos limites de alocação dos investimentos. Quanto aos investimentos em renda fixa (art. 35), a resolução estabelece que devem observar, em relação ao valor dos recursos de cada plano de benefícios, o máximo de $100 \%$ em títulos da divida mobiliária federal, ou $80 \%$ se desconsiderados estes títulos, distribuídos entre os demais investimentos em renda fixa (máximo de $20 \%$ para cada modalidade). Ou seja, a resolução faculta às EFPC a possibilidade de investir todos os recursos do seu plano de benefícios na dívida pública federal - que normalmente é considerado como um investimento conservador, de risco baixo.

Em relação aos investimentos em renda variável (art. 36), eles podem chegar a até $70 \%$ do valor de cada plano de benefícios, sendo que a referida legislação impõe limites adicionais diferenciados de acordo com o nível em que as companhias abertas operam na Bolsa de Valores. As companhias negociadas no "Novo Mercado", por exemplo, podem representar $70 \%$ dos ativos de cada plano, enquanto aquelas negociadas no "Nível 2" podem chegar a apenas 60\%. Esses "níveis" nas quais as empresas são negociadas dizem respeito à observância de regras de governança corporativa. Quanto mais alto o "nível", maior o limite para aplicação dos recursos das EFPC. Quanto às SPE, o limite é de $20 \%$ dos recursos de cada plano, enquanto o limite para outras modalidades de investimento de renda variável é de apenas $3 \%$.

Já os investimentos estruturados podem representar até $20 \%$ dos recursos de cada plano de benefício (art. 37), sendo 10\% em fundos de investimento imobiliário e $10 \%$ em fundos multimercado, Fundos de Investimento em Participações - FIP e Fundos de Investimento em Empresas Emergentes. Os investimentos no exterior devem observar o limite de $10 \%$, enquanto $8 \%$ dos recursos de cada plano de benefício podem ser aplicados em imóveis (arts. 38 e 39). As operações com participantes devem observar o 
limite de $15 \%$ em relação aos fundos garantidores de cada plano (aqui o percentual aplicado não se refere ao total dos recursos do plano de benefícios).

\begin{tabular}{|c|c|}
\hline \multicolumn{2}{|c|}{ Eabela 4 - Principais limites de alocação por modalidade de investimento das } \\
\hline Modalidade & Percentual \\
\hline Renda fixa & $100 \%$ \\
\hline Dívida mobiliária federal & $100 \%$ \\
\hline Outros investimentos em renda fixa & $80 \%$ \\
\hline Renda variável & $70 \%$ \\
\hline Companhias negociadas no "Novo Mercado" & $70 \%$ \\
\hline Sociedades de Propósito Específico & $20 \%$ \\
\hline Investimentos Estruturados & $20 \%$ \\
\hline Fundos Imobiliários & $10 \%$ \\
\hline Fundos: Multimercado, de Investimento em Participações & $10 \%$ \\
\hline e de Investimento em Empresas Emergentes & $10 \%$ \\
\hline Investimentos no Exterior & $8 \%$ \\
\hline Imóveis & \\
\hline
\end{tabular}

Elaboração Própria. Valores considerados em relação ao total dos recursos de cada plano de benefícios das EFPC. Fonte: Resolução no 3.792/2009 do CMN.

O órgão regulador dos investimentos mostrou preocupação ainda com a distribuição dos recursos da EFPC em diferentes emissores e investimentos. Por isso, também aqui previu limites máximos de concentração, relativos tanto ao valor de cada plano de benefícios, quanto ao total de recursos por ela administrados (arts. 41 a 43).

Quanto aos limites por emissor destacamos: 20\% se o emissor for instituição financeira; $10 \%$ se o emissor for SPE, tesouro estadual ou municipal, companhia aberta ou patrocinador do plano de benefícios, dentre outros; além de $100 \%$ se o emissor for o Tesouro Nacional (coerente com o limite de $100 \%$ para títulos da dívida federal). Considerada a soma total dos recursos administrados pelas EFPC, os limites de concentração são de 25\%: i) do capital total de uma mesma companhia aberta ou de uma mesma SPE; ii) do capital votante de uma mesma companhia aberta; iii) do 
patrimônio líquido de uma mesma instituição financeira, e; iv) do patrimônio líquido de um mesmo fundo de investimento.

Outras disposições importantes da Resolução 3.792/2009 são a vedação da realização de aplicações no exterior (note-se que as possibilidades admitidas na modalidade investimentos no exterior tratam de fundos constituídos no Brasil e/ou negociados em bolsas brasileiras), a vedação à atuação como instituição financeira e a vedação à atuação como incorporadora, seja de forma direta ou indireta, e a vedação a aplicar em ativos ou modalidades não previstas na resolução.

\subsection{Conclusões preliminares}

Ao chegar neste ponto do trabalho, já é possível apontar algumas conclusões preliminares sobre o desenho jurídico que rege a Previdência Complementar. O Brasil mantém um sistema sustentado em dois pilares: o público, sob regime de repartição, com as características de universalidade e solidariedade (apesar de ter um caráter contributivo), com piso e teto para o valor dos benefícios; e o complementar, sob regime de capitalização, administrado por entidades abertas e fechadas de previdência.

No sistema público, a existência do piso garante a todos os brasileiros que contribuem para a previdência o mínimo de proteção, vinculada ao valor do salário mínimo, para os casos de invalidez e aposentadoria. Por sua vez, a existência de um teto do valor pago pelos benefícios limita e dá um caráter mais distributivo ao gasto público com a previdência, além de estimular a busca por uma complementação no setor privado, com as entidades abertas e fechadas de previdência complementar, que atuam no regime de capitalização.

Tal estímulo foi acentuado com as reformas constitucionais de 1998 e 2003, com a imposição de regras mais rígidas para as aposentadorias do sistema público e para o cálculo de seus benefícios. Vimos também que o deslocamento destes recursos para as EAPC e EFPC provocaria um aumento da poupança interna e consequentemente do nível de investimento no país, e que estes foram objetivos implícitos e explícitos dessas reformas.

Especialmente, os empregados das empresas estatais, cujo contrato de trabalho é regido pela CLT, são segurados do RGPS, estando, assim, submetidos ao teto e ao fator previdenciário, e têm nas EFPC uma alternativa para a complementação da renda na 
aposentadoria e na cobertura de demais riscos sociais. Estes empregados podem também recorrer às EAPC que atuam concorrentemente no mercado financeiro, entretanto, as EFPC apresentam o atrativo do aporte de recursos pelo patrocinador, o que tende a gerar melhores resultados em termos de benefícios futuros.

Assim, o sistema da Previdência Social constitui-se num serviço público prestado pelo Estado através do Regime Geral de Previdência Social (RGPS) e dos Regimes Próprios de Previdência Social dos servidores públicos. Já na Previdência Complementar é um terreno primordialmente da iniciativa privada, no qual a atuação do Estado como regulador e fiscalizador justifica-se pelo relevante interesse público. Temos uma atuação do Estado sobre o domínio econômico.

Esta atuação tem como objetivos a higidez do sistema, para a garantia do pagamento dos beneficiários, a garantia do acesso dos beneficiários às informações sobre os planos de benefícios e a credibilidade da Previdência Complementar, de modo a atrair mais usuários e a fomentar o nível de poupança interna do país. A atuação estatal também se dá sob os princípios da Ordem Econômica da Constituição de 1988, com o objetivo de compatibilizar a ação dos entes privados com a política previdenciária e $\mathrm{o}$ desenvolvimento social e econômico-financeiro do país.

Com as Leis Complementares 108/2001 e 109/2001, buscou-se ordenar a atuação das EAPC e EFPC, exatamente tendo em vista o equilíbrio atuarial, a garantia dos benefícios e a proteção dos beneficiários, estabelecendo requisitos para os administradores, atribuindo responsabilidades e prevendo estruturas de governança mínimas. Para as EFPC patrocinadas pelo poder público, a lei previu paridade nos colegiados de decisão, em especial o Conselho Deliberativo e o Conselho Fiscal, com voto de qualidade dos patrocinadores (entes da Administração Pública) naquele e dos participantes e assistidos nestes.

Quanto ao órgão regulador das EFPC, o CNPC, este é um colegiado com participação de entidades, patrocinadores e participantes, mas com maioria de integrantes do poder público. Já o órgão fiscalizador e supervisor é a Previc, uma autarquia vinculada ao Ministério da Previdência Social. Contudo, estes órgãos não têm a atribuição de regular a política de investimentos dos fundos, que ficou a cargo do Conselho Monetário Nacional (CMN). 
A LC 109/2001 impediu a imposição de limites mínimos para as modalidades de investimento das entidades de previdência, inclusive as fechadas. Com isso, perdeu-se uma importante oportunidade de criar mecanismos jurídicos que alocassem recursos em determinados investimentos. Também o CMN, na sua Resolução 3.792/2009, emana uma regulamentação preocupada especialmente com os riscos envolvidos nas operações com os recursos das entidades, permitindo maior aporte em investimentos com rentabilidade garantida, como os títulos da dívida pública, ou, pelo menos, com um nível maior de segurança, como as companhias abertas que operam no Novo Mercado da Bovespa. Na mesma linha de prevenir riscos, a Resolução impõe uma diversificação na carteira de investimentos de cada plano de benefícios e do total de recursos administrados pelas EFPC.

Percebe-se, assim, a ausência de mecanismos que garantam ou, pelo menos, estimulem o direcionamento do montante de poupança arrecadado por estas entidades para projetos específicos ou estratégias específicas de desenvolvimento, como investimentos em infraestrutura, em operações imobiliárias ou em concessionárias de serviço público, para citar alguns exemplos. Todavia, isto não impede que os recursos sejam destinados para estes fins. Adicionalmente, a regulamentação dá discricionariedade aos administradores dos recursos, e sabemos que, nas Entidades Fechadas de Previdência Complementar patrocinadas por entes do poder público, como empresas estatais, a maioria dos votos no Conselho Deliberativo, considerando o voto de desempate é da empresa estatal patrocinadora. Por isso, chamamos estas entidades de paraestatais. Afinal, além de receberem aportes de entes públicos, o poder público tem lugar privilegiado na sua estrutura de governança. É utilizando-se destas entidades que o Estado poderá atuar na economia, participando e controlando empresas, concessionárias de serviço público, ou mesmo manejando com a compra de títulos da dívida.

Nosso desafio, no próximo capítulo dessa dissertação, é verificar como, sob quais condições e em qual sentido isto acontece. Em suma, buscaremos compreender como o Estado pode atuar no domínio econômico através das Entidades Fechadas de Previdência Complementar patrocinadas por suas empresas. 


\section{A ATUAÇÃO DOS FUNDOS DE PENSÃO DAS EMPRESAS ESTATAIS}

No capítulo 1 deste trabalho pudemos analisar a forma da inserção brasileira no que Arrighi chamou de ciclo de acumulação americano. Vimos que, durante boa parte do século XX, o país logrou um modelo de desenvolvimento no qual ocupavam lugares privilegiados o funding propiciado pelo fluxo de capitais externos e a articulação da ação do Estado brasileiro na mobilização de recursos. Nos anos 1980, porém, a crise da dívida provoca a interrupção desse fluxo externo e também a desorganização fiscal do Estado brasileiro, com a perda das capacidades estatais para articulação da economia.

Desde então, e mesmo com a retomada da entrada de capitais na década de 1990, o país não conseguiu, a contento, enfrentar um desafio: encontrar fontes internas relativamente estáveis para financiar o desenvolvimento. Para Luciano Coutinho, essa é um problema que se abateu sobre os países da América Latina de uma forma geral:

A ausência de sistemas doméstico de poupança e financiamento, robustos e suficientes para a sustentação de um novo ciclo de desenvolvimento, constitui um fator fragilizador para as economias da América Latina. ${ }^{263}$

Com efeito, Fernando Nogueira da $\operatorname{Costa}^{264}$ defende que o ciclo recente de crescimento brasileiro na década de 2000 encontra sua limitação nesta ausência de funding que proporcione autonomia para o país conduzir suas políticas internas e consolidar uma rota de desenvolvimento sustentado:

Recentemente, o movimento das forças de mercado, apoiado por políticas públicas, conseguiu alcançar alguns fatores endógenos de dinamismo da economia brasileira: a dimensão significativa do seu mercado interno e sua diversificação setorial. Porém, são fatores de esgotamento de ciclos de crescimento as carências de autonomia

\footnotetext{
${ }^{263}$ COUTINHO, Luciano. O desenho de um novo modelo de financiamento para a América Latina. In: COUTINHO (Org.). Fundos de Pensão: novo fator de desenvolvimento para a América Latina. IE/UNICAMP. Campinas, 1996, p. 1.

${ }^{264}$ COSTA, Fernando Nogueira da. Financiamento interno de longo prazo. In CALIXTRE, André Bojikian; BIANCARELLI, André Martins; CINTRA, Marcos Antonio Macedo. Presente e futuro do desenvolvimento brasileiro. IPEA. Brasília, 2014, p. 293.
} 


$$
\begin{aligned}
& \text { nacional em inovação tecnológica e financiamento do } \\
& \text { desenvolvimento. }^{265} \text { (grifo nosso) }
\end{aligned}
$$

Tendo em vista o problema explicitado acima, qual seja, a necessidade de provimento de fontes autônomas para o financiamento do desenvolvimento, este capítulo examinará o papel que as Entidades Fechadas de Previdência Complementar patrocinadas por empresas estatais vem cumprindo como funding para a economia brasileira.

Por serem geridos a longo prazo, os recursos dos chamados "fundos de pensão" podem cumprir o papel de ser uma fonte estável de financiamento de longo prazo para economia $^{266}$.

Faremos isso por meio da verificação da composição da carteira das três maiores EFPCs brasileiras: a Previ (patrocinada pelo Banco do Brasil), a Petros (patrocinada pela Petrobrás) e a Funcef (patrocinada pela Caixa Econômica Federal). Veremos de que forma se dá a participação destas entidades em algumas das principais empresas e empreendimentos nacionais. Esta verificação será realizada a partir de dados dos órgãos reguladores, de dados oficiais publicados pelos fundos de pensão e de relatórios das companhias participadas. Na última parte do capítulo, analisaremos a origem e o perfil dos dirigentes das principais EFPCs do país, representados por seus presidentes, no período que começa a partir da entrada em vigor da legislação.

\subsection{O Estado investidor e as EFPCs}

Consultora do governo britânico para crescimento e inovação e professora da Universidade de Sussex no Reino Unido, Mariana Mazzucato discute em seu livro "O Estado empreendedor" ${ }^{267}$ o papel do Estado na economia e especialmente na inovação, com base no exemplo do desenvolvimento tecnológico estadunidense em diferentes áreas do conhecimento.

A autora defende a existência e o fortalecimento de um Estado empreendedor, cuja atuação não se resuma à correção das falhas de mercado, nem à ação contracíclica

\footnotetext{
265 COSTA, Fernando Nogueira da. Financiamento interno de longo prazo. In CALIXTRE, André Bojikian; BIANCARELlI, André Martins; CINTRA, Marcos Antonio Macedo. Presente e futuro do desenvolvimento brasileiro. IPEA. Brasília, 2014, p. 293.

266 MATIJASCIC. Milko. Fundos de pensão e rearticulação da economia brasileira. Campinas: UNICAMP, 1994, pp. 25-26

${ }^{267}$ MAZZUCATO, Mariana. O Estado Empreendedor: desmascarando o mito do setor público vs. setor privado. Trad. Elvira Serapicos. $1^{\mathrm{a}}$ ed. Portifólio-Penguin, São Paulo, 2014.
} 
pregada por Keynes. Mazzucato utiliza a metáfora do "tigre"268 para explicar a atuação do setor publico na formação e criação de mercados, principalmente nos setores cujos graus de incerteza e risco são tão altos, como no caso da inovação. Para Mariana, o Estado empreendedor não apenas reduz riscos por meio da provisão de funding, mas também antevê o espaço de risco e opera para "fazer as coisas acontecerem". O setor público não apenas reúne (crowd in) os investimentos do empresariado, como também o dinamiza e o orienta.

Este cenário, segundo a autora, é o pano de fundo do extraordinário avanço tecnológico observado no Vale do Silício ${ }^{269}$ nas últimas décadas, bem como a realidade da indústria farmacêutica e do desenvolvimento de novos medicamentos. No caso da indústria farmacêutica $^{270}$, a autora aponta uma divisão do trabalho entre as instituições públicas e privadas. Enquanto os laboratórios financiados com dinheiro público produziram cerca de $75 \%$ dos medicamentos inovadores entre 1993 e 2004, os laboratórios privados investem prioritariamente em variações menos arriscadas de medicamentos já existentes (com dosagem diferente, por exemplo) e em campanhas de marketing para promoção destas drogas com pequena variação. Além disso, com o processo de financeirização em curso, as farmacêuticas são levadas a investir parte dos excedentes na recompra das suas ações, com o intuito de valorizá-las, em detrimento da inversão em Pesquisa e Desenvolvimento $-\mathrm{P} \& \mathrm{D}^{271}$.

No que se refere ao recente surto de desenvolvimento tecnológico de ponta na indústria eletrônica de consumo e nos setores ligados à internet, a autora utiliza o exemplo da Apple, empresa de sucesso mundial que criou e comercializa produtos como o iPod, o iPhone e o iPad. Com o caso Apple, a autora busca mostrar que o Estado cumpre diversas funções na estruturação dos mercados, sem as quais uma empresa com essas características não seria viável. Segundo Mazzucato ${ }^{272}$, a atuação estatal está presente em todas as tecnologias utilizadas no iPhone, desde os semicondutores de silício até à

\footnotetext{
268 Trata-se da discussão sobre os homens de negócios realizada por Keynes e recuperada pela autora. Para Keynes, os homens de negócios não teriam o espírito animal de tigres e lobos, mas o comportamento de animais domesticados. Para Mazzucato, o setor público seria o tigre. Ver: MAZZUCATO, Mariana. $O$ Estado Empreendedor: desmascarando o mito do setor público vs. setor privado. Trad. Elvira Serapicos. $1^{\mathrm{a}}$ ed. Portfólio-Penguin, São Paulo, 2014, pp. 28-33.

${ }^{269}$ Região do estado da Califórnia, na costa oeste dos Estados Unidos, na qual estão instaladas empresas tecnológicas de ponta, como a Apple, o Facebook e o Google, dentre outras.

${ }^{270}$ MAZZUCATO, op. cit., 2014, pp. 100-103.

${ }^{271}$ Ibidem, pp. 54-57.

272 Ibidem, pp. 136-154.
} 
tela de cristal líquido sensível ao toque, passando pelo HTTP (sigla em inglês para protocolo de transferência de hipertexto), que viabiliza a internet.

Este apoio estatal se deu direta ou indiretamente, de três maneiras principais ${ }^{273}$ : i) Investimento direto de capital nos estágios iniciais de criação e crescimento; ii) Viabilização do acesso a tecnologias resultantes de pesquisas governamentais, iniciativas militares e contratos públicos, e; iii) Criação de políticas fiscais, comerciais e de tecnologia para apoiar empresas dos EUA.

Das várias agências do governo estadunidense que participaram deste processo de intensa inovação tecnológica, destaca-se a DARPA (sigla em inglês para Agência de Projetos de Pesquisa Avançada de Defesa). ${ }^{274}$ A DARPA foi criada para dar aos EUA superioridade tecnológica no período posterior à segunda guerra mundial. Financiou a formação de departamentos de ciência da computação, deu apoio a startups com pesquisas iniciais, contribuiu para a pesquisa de semicondutores, apoiou a pesquisa da interface homem-computador e supervisionou os estágios iniciais da internet.

A agência atuou para furar o bloqueio de grandes empresas de defesa, possibilitando ao governo estadunidense liderar a mobilização pela inovação, com laboratórios próprios e de suas universidades. A DARPA possui dinâmica flexível, atuando por meio de uma série de escritórios pequenos com autonomia e formados por cientistas e engenheiros de ponta, que definem uma agenda para os pesquisadores de campo. Nesse arranjo, o financiamento ramifica-se entre pesquisadores de universidades, startups, empresas estabelecidas e consórcios industriais.

De fato, Mazzucato mostra que o governo esteve presente desde o financiamento ativo a pesquisas iniciais até a criação de redes necessárias entre as agências estatais e o setor privado para facilitar o desenvolvimento comercial, contribuindo, inclusive, para que as empresas levem os produtos para o estágio da viabilidade comercial em áreas de desenvolvimento tecnológico consideradas estratégicas:

(...) os Estados Unidos passaram as últimas décadas usando políticas intervencionistas bastante ativas para estimular a inovação no setor privado visando objetivos mais amplos para as políticas públicas. $\mathrm{O}$

\footnotetext{
${ }^{273}$ MAZZUCATO, Mariana. O Estado Empreendedor: desmascarando o mito do setor público vs. setor privado. Trad. Elvira Serapicos. $1^{a}$ ed. Portfólio-Penguin, São Paulo, 2014, p. 134.

${ }^{274}$ Ibidem, pp. 110-116.
} 
que essas três intervenções têm em comum é o fato de não comprometerem o governo com nenhuma empresa específica, embora ele continue a "escolher vencedores"; não existem acusações de políticas industriais ineficientes. ${ }^{275}$

Mazzucato cita ainda experiências nas áreas de nanotecnologia e tecnologia verde, e de alguns países como China e Brasil (especificamente o BNDES), para exemplificar o que chama de Estado empreendedor e recomendar ao governo do Reino Unido a adoção de medidas visando a fortalecer as instituições públicas e fomentar a inovação. Sobre as experiências descritas no livro, a pesquisadora aponta:

As lições dessas experiências são importantes. Elas obrigam o debate a ir além do papel do Estado no estímulo à demanda, ou da preocupação de 'escolher vencedores'. Em vez disso, o que temos é um caso de Estado direcionado, proativo, empreendedor, capaz de assumir riscos e criar um sistema altamente articulado que aproveita o melhor do setor privado para o bem nacional em um horizonte de médio e longo prazo. É o Estado agindo como principal investidor e catalisador, que desperta toda a rede para a ação e difusão do conhecimento. O Estado pode e age como criador, não como mero facilitador da economia do conhecimento. ${ }^{276}$

Decerto que os elementos da análise de Mazzucato não são completamente novos. Mas o seu livro contribui com um ângulo diferente de visão sobre o papel do Estado e suas formas de atuação. Mesmo se restringindo à questão da inovação tecnológica, acreditamos que podemos projetar a ideia de um Estado empreendedor ou investidor em outros setores da economia, como, por exemplo, a infraestrutura.

A obra de Mazzucato dialoga com o que vimos no primeiro capítulo desta dissertação e converge com diversos autores brasileiros chamados desenvolvimentistas ao reconhecer o papel do Estado na criação e estruturação dos mercados e no provimento de produtos e serviços, especialmente daqueles cuja criação e produção demandam maior aporte inicial de recursos e também maior risco. A autora elenca, ainda, diversas formas de atuação estatal, entre algumas já estudadas e praticadas há décadas no Brasil, como os

\footnotetext{
${ }^{275}$ MAZZUCATO, Mariana. O Estado Empreendedor: desmascarando o mito do setor público vs. setor privado. Trad. Elvira Serapicos. $1^{\text {a }}$ ed. Portfólio-Penguin, São Paulo, 2014 , p. 121.

${ }^{276}$ Ibidem, p. 48.
} 
incentivos fiscais, o financiamento a setores considerados estratégicos e o desenvolvimento de pesquisa básica e aplicada. Mas também amplia o leque de possibilidades estatais com formas de atuação tais quais a participação acionária ${ }^{277} \mathrm{em}$ empresas e a articulação de agências do Estado com o setor privado. No caso brasileiro, estas possibilidades podem se concretizar através de empresas estatais, bancos públicos e fundos paraestatais, e também das EFPCs patrocinadas por estatais.

Com efeito, Fernando Nogueira da $\operatorname{Costa}^{278}$ aponta que as iniciativas particulares vencedoras no Brasil têm em comum o financiamento ofertado por instituições públicas federais (BNDES, Banco do Brasil, Caixa Econômica Federal e bancos regionais), a articulação com órgãos governamentais de pesquisa, como a Empresa Brasileira de Pesquisa Agropecuária (Embrapa) e a Financiadora de Estudos e Projetos (Finep), e a associação com empresas estatais (a exemplo da Petrobras) e instituições paraestatais, como as EFPCs patrocinadas por estatais. Vejamos algumas das características destes instrumentos.

\subsubsection{Os fundos públicos}

Mesmo com a fragilização do Estado no plano fiscal, determinados fundos públicos ${ }^{279}$ continuam cumprindo papel importante no financiamento da economia nacional, especialmente no que diz respeito ao financiamento de longo prazo. Além disso, estes fundos ganharam ainda mais relevância com a perda de capacidade da atuação direta do Estado no domínio econômico.

Os principais fundos públicos são o FGTS (Fundo de Garantia por Tempo de Serviço), o FAT (Fundo de Amparo ao Trabalhador), e os fundos de desenvolvimento regional, quais sejam: Fundo de Desenvolvimento do Nordeste (FDNE), Fundo de Desenvolvimento da Amazônia (FDA) e o Fundo de Desenvolvimento do Centro-Oeste

\footnotetext{
277 Aqui, não falamos no Estado tão somente enquanto controlador das empresas, mas também como acionista minoritário, conforme será visto adiante.

${ }^{278}$ COSTA, Fernando Nogueira da. Financiamento interno de longo prazo. In CALIXTRE, André Bojikian; BIANCARELLI, André Martins; CINTRA, Marcos Antonio Macedo. Presente e futuro do desenvolvimento brasileiro. IPEA. Brasília, 2014, pp. 293-295.

${ }^{279}$ Enquanto os fundos regionais e setoriais recebem recursos da arrecadação tributária, o FGTS e o FAT são considerados fundos parafiscais. A parafiscalidade destes fundos é caracterizada pelo caráter compulsório das contribuições os financiam, bem como pelo fato de as suas receitas não integrarem o orçamento do Estado e da sua administração ficar a cargo de entes descentralizados.
} 
(FDCO). Com um volume significativo de recursos arrecadados, consolida-se com estes fundos um patrimônio significativo destinado $\mathrm{a}^{280}$ :

a) Implantar projetos de infraestrutura econômica e social - estradas, portos, ferrovias, energia elétrica, habitação, saneamento básico, etc.;

b) Investir em ampliação da capacidade produtiva e criação de empregos;

c) No caso dos fundos de desenvolvimento regional, promover o desenvolvimento econômico e social das regiões mais atrasadas, por intermédio de programas de financiamento aos setores produtivos.

O FGTS, criado em 1967, tem a finalidade precípua de proteger o trabalhador demitido sem justa causa. É constituído por contas vinculadas, abertas em nome de cada trabalhador, cujo saldo é formado pelos depósitos mensais efetivados pelo empregador. Com o FGTS, o trabalhador tem a oportunidade de formar um patrimônio, que pode ser sacado em momentos especiais.

Todavia, a função do fundo não se limita aos benefícios sociais para os trabalhadores formais. O FGTS tem sido a maior fonte de recursos para a Habitação Popular e o Saneamento Básico, e tem ampliado a sua atuação, desde 2008, direcionando recursos para outros segmentos da infraestrutura, beneficiando especialmente o setor de energia elétrica, no qual tem comprado participação em empresas privadas de capital fechado. Destacam-se, também, os subsídios concedidos a fundo perdido para o Programa Minha Casa Minha Vida. ${ }^{281} \mathrm{O}$ total de ativos do FGTS chegou a 325 bilhões de reais ${ }^{282} \mathrm{em}$ dezembro de 2013.

Além disso, destaca-se, recentemente, a criação do Fundo de Investimento do Fundo de Garantia do Tempo de Serviço (FI-FGTS) no âmbito do Programa de Aceleração do Crescimento (PAC). ${ }^{283} \mathrm{O}$ fundo de investimento destina-se a empreendimentos na área de infraestrutura, atuando por meio da participação acionária nestes empreendimentos, na compra de fundos de investimento, debêntures, derivativos e títulos públicos federais. O FI-FGTS pode participar, também, de projetos realizados através de parcerias público-privadas (PPP) e administrados por um Comitê de Investimento,

\footnotetext{
${ }^{280}$ COSTA, Fernando Nogueira da. I Relatório de Pesquisa para o IPEA. PND 059-2012. 2012, p. 19. ${ }^{281}$ Ibidem, pp. 22-28.

282 Fonte: Demonstrações contábeis do FGTS - Exercício 2013. Disponível em: $<$ http://downloads.caixa.gov.br/arquivos/fgts/demonstracao financeira fgts/DEMONSTRACAO FINA NCEIRA_FGTS_2013.pdf $>$. Acesso em: 17.11.2014.

${ }^{283}$ Ver Lei 11.191/2007.
} 
composto por representantes governamentais, de empregadores e trabalhadores (os dois últimos por meio de confederações sindicais patronais e centrais sindicais, respectivamente).

O FAT, por sua vez, foi criado pela Constituição de 1988 através da unificação dos fundos constituídos com recursos do Programa de Integração Social (PIS) e do Programa de Formação do Patrimônio do Servidor Público (PASEP). Das contribuições do PIS-PASEP, $60 \%$ devem ser destinadas ao pagamento de abono salarial e seguro desemprego, enquanto $40 \%$ se destinam ao Banco Nacional de Desenvolvimento Econômico e Social (BNDES).

A destinação dos recursos do FAT ao BNDES assegurou uma fonte segura de recursos para o banco, chegando, em 2011, a 23,4\% das suas receitas. Entretanto, a importância do FAT para a obtenção de recursos para o BNDES vem decaindo, por conta da alta do salário mínimo e da média do rendimento dos brasileiros, além da alta rotatividade do mercado de trabalho, que implica no aumento dos gastos com seguro desemprego. Desde 2009, o Tesouro Nacional passou a ser o principal financiador do BNDES e também vêm aumentando as suas contribuições para o próprio FAT, de modo a evitar déficits no fundo. ${ }^{284}$ Apesar disso, o patrimônio do FAT chegou a 227 bilhões de reais em agosto de $2014 .^{285}$

Há também 17 fundos setoriais de ciência e tecnologia que constituem instrumentos de financiamento de projetos de pesquisa, desenvolvimento e inovação no país. Eles visam à execução de projetos em instituições cientificas que incluem não só a geração de conhecimento como também a transferência tecnológica para empresas. ${ }^{286}$ Com exceção do Fundo para o Desenvolvimento Tecnológico das Telecomunicações (Funttel), que é gerido pelo Ministério das Comunicações, os demais fundos setoriais são administrados pela Finep.

Em comum os fundos públicos dos quais tratamos:

\footnotetext{
${ }^{284}$ COSTA, Fernando Nogueira da. I Relatório de Pesquisa para o IPEA. PND 059-2012. 2012, pp. 2932.

285 Boletim de informações financeiras do FAT. $4^{\circ}$ bimestre de 2014. Disponível em <http://portal.mte.gov.br/data/files/FF80808148EC2E5E01497683654B0F4A/KIT\%204\%C2\%BA\%20BI MESTRE\%202014.pdf >. Acesso em: 17.11.2014.

286 INSTITUTO DE PESQUISA ECONOMICA APLICADA. Estado, instituições e democracia: desenvolvimento. Livro 9, Volume 3. Ipea, Brasília, 2010, pp. 594-595.
} 
(...) constituem-se como fundos contábeis e financeiros, garantindo acumulação patrimonial, fluxos constantes de receita por estarem vinculados a fontes de arrecadação, além de gestão financeira específica e compartilhada (...). Assim, esse tipo de instrumento garante disponibilidade de recursos para além dos exercícios fiscais e orçamentários, e o patrimônio acumulado permite o desenho e execução de programas de fomento ao desenvolvimento econômico e tecnológico. $^{287}$

Podemos concluir que os fundos públicos conferem uma fonte relativamente estável de funding para a economia nacional, além da atuação em setores e regiões específicos, com considerável capacidade de atuação na economia, dado o volume de recursos que gerem e também a capacidade discricionária de atuação, em especial aqueles fundos que não têm gastos legais obrigatórios definidos. Esta capacidade discricionária, que também é uma característica marcante na regulação dos investimentos das Entidades Fechadas de Previdência Complementar (vide capítulo 2), pode propiciar aos fundos a liberdade de alocar recursos e investir em áreas que o mercado por si só não da conta, como vimos nos autores estudados até agora. Além disso, pode-se perceber que os fundos públicos começam a atuar também com participação acionária em empreendimentos, negociando ativos no mercado financeiro e em bolsas de valores, como é o caso do FI-FGTS.

\subsubsection{Os bancos públicos}

Os bancos públicos brasileiros são outra importante alternativa de funding nacional. Isso ocorre porque as instituições bancárias têm, segundo uma abordagem keynesiana ${ }^{288}$, a prerrogativa de criar moeda escritural a partir dos seus empréstimos, e por isso são essenciais para disponibilizar recursos iniciais para o investimento. No caso dos bancos públicos, as operações com crédito direcionado e a taxas de juros inferiores às de mercado contribuem para a geração de funding.

Sua atuação justifica-se, sobretudo, pela necessidade de autonomia financeira para implementar políticas de desenvolvimento, que envolvem estímulo a investimentos privados em setores estratégicos (infraestrutura, inovações, etc.), ou mesmo programas de investimentos públicos nestes setores. A autonomia dos bancos públicos é maior que

287 INSTITUTO DE PESQUISA ECONOMICA APLICADA. Estado, instituições e democracia: desenvolvimento. Livro 9, Volume 3. Ipea, Brasília, 2010, p. 592.

${ }^{288}$ Ibidem, pp. 547-549. 
a do governo central, pois podem recorrer a fontes diversificadas de financiamento, como a captação de poupança doméstica, empréstimo de outras instituições financeiras e reinvestimento do excedente operacional; além de gerirem recursos de alguns dos fundos parafiscais que vimos anteriormente, como o FAT no caso do Banco Nacional de Desenvolvimento Econômico e Social (BNDES) e do FGTS no caso da Caixa Econômica Federal (CEF). ${ }^{289}$

Os bancos públicos no Brasil destacam-se na oferta de financiamento de longo prazo, pois estas operações são marcadas por elevado grau de incerteza:

(...) o desenvolvimento econômico envolve investimentos em setores, produtos e/ou processos produtivos novos, o que tende a torna-lo um processo marcado por grandes incertezas e elevados custos. Por outro lado, os ofertantes de fundos (pessoas físicas e instituições financeiras) tendem a rejeitar riscos presumidamente muito elevados: além das dificuldades de previsão da exata proporção destes riscos, sua incorporação às taxas de retorno exigidas dos ativos pode ser dificultada pela retração da demanda por recursos. ${ }^{290}$

A importância destes bancos para a economia brasileira pode ser medida pela sua participação no crédito em alguns setores, como no crédito industrial (cerca de $40 \%$ do total), na habitação (73\%) e na agropecuária (média histórica de 50\%). Também se destaca a atuação anticíclica destas instituições financeiras, a exemplo da crise de 20082009, quando houve crescimento negativo do crédito ao setor industrial no setor privado, enquanto no setor público o crescimento foi em média de $4 \%$ ao mês ${ }^{291}$.

No caso específico do BNDES, Mario Schapiro ${ }^{292}$ mostra que o banco esteve alinhado com as prioridades governamentais previstas no Plano de Metas e no II Plano Nacional de Desenvolvimento (II PND), momentos cruciais da industrialização brasileira. No Plano de Metas, direcionou o crédito especialmente para o setor ferroviário e elétrico,

\footnotetext{
${ }^{289}$ INSTITUTO DE PESQUISA ECONOMICA APLICADA. Macroeconomia para o Desenvolvimento: crescimento, estabilidade e emprego. Livro 4. Ipea, Rio de Janeiro, 2010, pp. 279-281.

${ }^{290}$ Ibidem, 2010, p. 279.

${ }^{291}$ O setor habitacional é servido principalmente pela Caixa Econômica Federal, enquanto o crédito rural fica a cargo do Banco do Brasil e o crédito à indústria é contemplado pelo BNDES. Fonte dos dados: INSTITUTO DE PESQUISA ECONOMICA APLICADA. Estado, instituições e democracia: desenvolvimento. Livro 9, Volume 3. Ipea, Brasília, 2010, pp. 558-567.

${ }^{292}$ SCHAPIRO, Mario Gomes. Novos Parâmetros para a Intervenção do Estado na Economia: persistência e dinâmica na atuação do BNDES em uma economia baseada no conhecimento. Tese de doutorado apresentada à Faculdade de Direito da USP. São Paulo, 2009, p. 101.
} 
enquanto no II PND os principais beneficiários com os recursos do banco foram os setores de insumos básicos e bens de capital.

No período recente o banco participou da formulação da política industrial (Política Industrial, Tecnológica e de Comércio Exterior - Pitce) brasileira e atua como um de seus principais financiadores. Em 2007, o banco também assumiu papel importante no Programa de Aceleração do Crescimento ${ }^{293}$. Para Schapiro, o BNDES vem adotando formas de atuação que passam a usar critérios de risco e rentabilidade (mais próximos do mercado) e a se aproximar do mercado de capitais. Todavia, continua, segundo o autor, como um importante mecanismo de regulação institucional, através de ferramentas societárias e contratuais que sugerem um novo tipo de parceira públicoprivada. $^{294}$ A BNDES Participações S/A - BNDESPAR, sociedade por ações que é subsidiária integral do BNDES, cumpre papel importante nesse sentido, pois tem a atribuição de operar com valores mobiliários para a consecução das finalidades do banco.

\subsubsection{As EFPCs patrocinadas por estatais}

As Entidades Fechadas de Previdência Complementar patrocinadas por empresas estatais constituem o que Fernando Nogueira da Costa chama de "a perna trabalhista" do capitalismo brasileiro, cujas outras três pernas seriam o capital estatal, o capital privado nacional e o capital privado internacional. ${ }^{295}$ De fato, a afirmativa vai ao encontro da hipótese deste trabalho, qual seja, a de que estes "fundos de pensão"296 são um instrumento de atuação do Estado no domínio econômico.

As EFPCs patrocinadas por estatais se caracterizam por serem entidades privadas, sem fins lucrativos, que arrecadam poupança pulverizada (e igualmente privada) de milhares de trabalhadores. São instituições que atuam no mercado participando de empresas, investindo no mercado financeiro e no setor imobiliário. Seus recursos não provêm diretamente da União e também não é a União que controla diretamente as entidades.

\footnotetext{
${ }^{293}$ INSTITUTO DE PESQUISA ECONOMICA APLICADA. Macroeconomia para o Desenvolvimento: crescimento, estabilidade e emprego. Op. cit., p. 300.

${ }^{294}$ SCHAPIRO, Mario Gomes. Novos Parâmetros para a Intervenção do Estado na Economia: persistência e dinâmica na atuação do BNDES em uma economia baseada no conhecimento. Tese de doutorado apresentada à Faculdade de Direito da USP. São Paulo, 2009, pp. 149-159.

${ }^{295}$ COSTA, Fernando Nogueira da. Financiamento interno de longo prazo. In CALIXTRE, André Bojikian; BIANCARELLI, André Martins; CINTRA, Marcos Antonio Macedo. Presente e futuro do desenvolvimento brasileiro. IPEA. Brasília, 2014

${ }^{296}$ Utilizaremos neste capítulo a expressão fundos de pensão como sinônimo de Entidade Fechada de Previdência Complementar.
} 
Portanto, estes recursos não poderiam, a priori, ser considerados como fundos públicos. $^{297}$

No entanto, ao considerarmos que: i) que conforme previsão da LC 108/2001 as estatais indicam metade dos membros do Conselho Deliberativo destas EFPCs, além de possuir o direito ao voto de minerva, e; ii) a forte presença estatal nos órgãos de regulação, supervisão e fiscalização; temos o caminho por meio do qual o governo central pode, mesmo que de forma indireta, utilizar as EFPCs como instrumentos de política econômica.

Vimos já no capítulo 1 que as EFPCs operam no mercado como investidores institucionais, ao lado de fundos mútuos, seguradoras e demais fundos de investimento. Todavia, ao contrário destes outros investidores institucionais, as EFPCs têm a característica de serem relativamente homogêneas quanto aos aspectos relacionados ao prazo de maturação de recursos. Isto é, os fundos de pensão são voltados à constituição de recursos com longo prazo de maturação, uma vez que o pagamento de obrigações começa a ser exigido em média 30 anos depois de iniciado o período contributivo. Isto propicia que as EFPCs possam fazer investimento com um horizonte de retorno a médio e longo prazo. Por outro lado, quando mais "maduro" o plano, menor a possibilidade de o gestor do plano adquirir ativos com risco mais elevado.

Os gestores das EFPCs submetem-se às exigências atuariais que são determinantes para definir o grau de risco ao qual ele pode se expor. O cálculo atuarial estabelece qual a taxa de crescimento mínima da massa de recursos sobre administração do fundo para fazer frente aos compromissos futuros. Algumas das variáveis atuariais que compõem este cálculo são ${ }^{298}:$ i) nível e periodicidade das contribuições; ii) taxa de rotatividade do emprego na empresa; iii) proporção de contribuição empregador/empregado, e; iv) cálculo do valor presente das exigibilidades do plano. Estima-se, para o caso brasileiro

\footnotetext{
${ }^{297}$ Em caso que guarda alguma semelhança, o Supremo Tribunal Federal, no julgamento da Ação Penal 470, considerou os recursos do Fundo Visanet como públicos, para caracterizar do crime de peculato do réu Henrique Pizzolato. O fundo foi criado por uma empresa, a Companhia Brasileira de Meios de Pagamento e partilhado por Banco do Brasil, Bradesco e outras instituições que operam com a marca Visa no país. Prevaleceu a tese de que o BB teria ganhos e perdas conforme o saldo das operações. $\mathrm{O}$ suposto desvio dos recursos, portanto, repercutiria nos cofres do banco estatal. Entretanto, o regulamento que cria o fundo rejeita expressamente a tese de que os recursos pertenciam ao Banco do Brasil. O Acórdão da Ação Penal 470 está disponível em: <www.stf.jus.br>.

${ }^{298}$ INSTITUTO DE PESQUISA ECONOMICA APLICADA. Estado, instituições e democracia: desenvolvimento. Livro 9, Volume 3. Ipea, Brasília, 2010, p. 648.
} 
que essa taxa esperada seja de $6 \%$ de rendimento real ao ano ${ }^{299}$, ou seja, descontada a inflação do período. Considerando a inflação acumulada dos últimos doze meses em outubro de $2014^{300}$, esta taxa atuarial mínima seria de $12,58 \%$.

Em 2014, eram 320 as EFPCs no Brasil ${ }^{301}$, sendo 38 delas patrocinadas por entidades públicas federais. O total de ativos das entidades chegava a 702,3 bilhões de reais, sendo 391,3 bilhões daquelas com patrocínio público federal. Já o total de investimento destes fundos era de 669,9 bilhões de reais, sendo 372,9 bilhões de fundos patrocinados por entidades do governo federal.

Ou seja, apesar de representarem apenas 11,8\% do universo de EFPCs, os fundos de pensão das estatais concentram 55,7\% dos ativos e 55,6\% dos investimentos. Isto se deve ao tamanho destes fundos de pensão, especialmente às três maiores EFPCs patrocinadas por entidades federais: a Previ, a Petros e a Funcef, que concentram, juntas, $80,4 \%$ destes ativos e são também os maiores no universo geral EFPCs. Abaixo, tabela dos 10 maiores fundos de pensão brasileiros, com o respectivo patrocínio.

\begin{tabular}{|l|l|l|l|}
\hline \multicolumn{3}{|l|}{ Tabela 5 - 10 maiores Entidades Fechadas de Previdência Complementar } \\
\hline Posição & EFPC & $\begin{array}{l}\text { Patrocínio } \\
\text { predominante }\end{array}$ & $\begin{array}{l}\text { Ativos } \\
\text { (em bilhões de reais) }\end{array}$ \\
\hline 1 & Previ & Público federal & 178,839 \\
\hline 2 & Petros & Público federal & 79,170 \\
\hline 3 & Funcef & Público federal & 56,706 \\
\hline 4 & Funcesp & Privado & 24,099 \\
\hline 5 & Itaú Unibanco & Privado & 19,120 \\
\hline 6 & Valia & Privado & 17,534 \\
\hline
\end{tabular}

299 INSTITUTO DE PESQUISA ECONOMICA APLICADA. Estado, instituições e democracia: desenvolvimento. Livro 9, Volume 3. Ipea, Brasília, 2010, p. 657.

${ }^{300}$ Inflação calculada pelo Índice Nacional de Preços ao Consumidor Amplo (IPCA), conforme dados de outubro de 2014 o índice acumulado em 12 meses chegava a 6,58\%. Disponível em: <http://www.ibge.gov.br/home/estatistica/indicadores/precos/inpc ipca/defaultinpc.shtm $>$. Acesso em 23.11.2014.

${ }^{301}$ Os dados apresentados neste parágrafo e nos seguintes sobre as EFPCs foram extraídos do Relatório Estatístico Trimestral da PREVIC, último disponível quando da conclusão deste trabalho. SUPERINTENDENCIA NACIONAL DE PREVIDENCIA COMPLEMENTAR (PREVIC). Estatística trimestral -junho de 2014. Ministério da Previdência Social: Brasília, 2014. Disponível em: <http://www.previdencia.gov.br/wp-content/uploads/2014/09/2-trim-2014.pdf > . Acesso em: 23.11.2014. 


\begin{tabular}{|l|l|l|l|}
\hline 7 & Banesprev & Privado & 15,031 \\
\hline 8 & Sistel & Privado & 14,459 \\
\hline 9 & Forluz & Público estadual & 13,041 \\
\hline 10 & Real Grandeza & Público Federal & 11,999 \\
\hline
\end{tabular}

Elaboração própria. Fonte PREVIC.

Para que se tenha uma real noção do quanto significam estes montantes, vale dizer que o total de ativos dos fundos de pensão de empresas estatais (391,3 bilhões de reais) representa $8 \%$ do PIB brasileiro de $2013 .{ }^{302}$

Desde a edição das Leis Complementares 108 e 109/2001, os ativos das EFPCs vêm se expandido de maneira constante, com exceção com ano de 2008, em que se registra uma leve retração da soma dos ativos das EFPCs, em geral, e uma forte contração dos ativos da Previ, em especial. Entre dezembro/2002 e junho/2014, observa-se um crescimento de $270 \%$ do total de ativos das EFPCs, sendo que na Previ o aumento foi de $296 \%$. Petros e Funcef registraram incremento de $325 \%$ e $509 \%$, respectivamente. No mesmo período, o crescimento do PIB nacional foi de $227 \%$ em termos nominais. ${ }^{303}$

\footnotetext{
302 O PIB a preços de mercado calculado pelo IBGE foi de 4,844 trilhões de reais em 2013. Dados disponíveis em: <http://www.ibge.gov.br/home/estatistica/indicadores/pib/pib-vol-val_201402_8.shtm>. Acesso em 23.11.2014.

303 Dados disponíveis em: <http://www.ibge.gov.br/home/estatistica/indicadores/pib/pib-volval_201402_8.shtm>. Acesso em 23.11.2014
} 


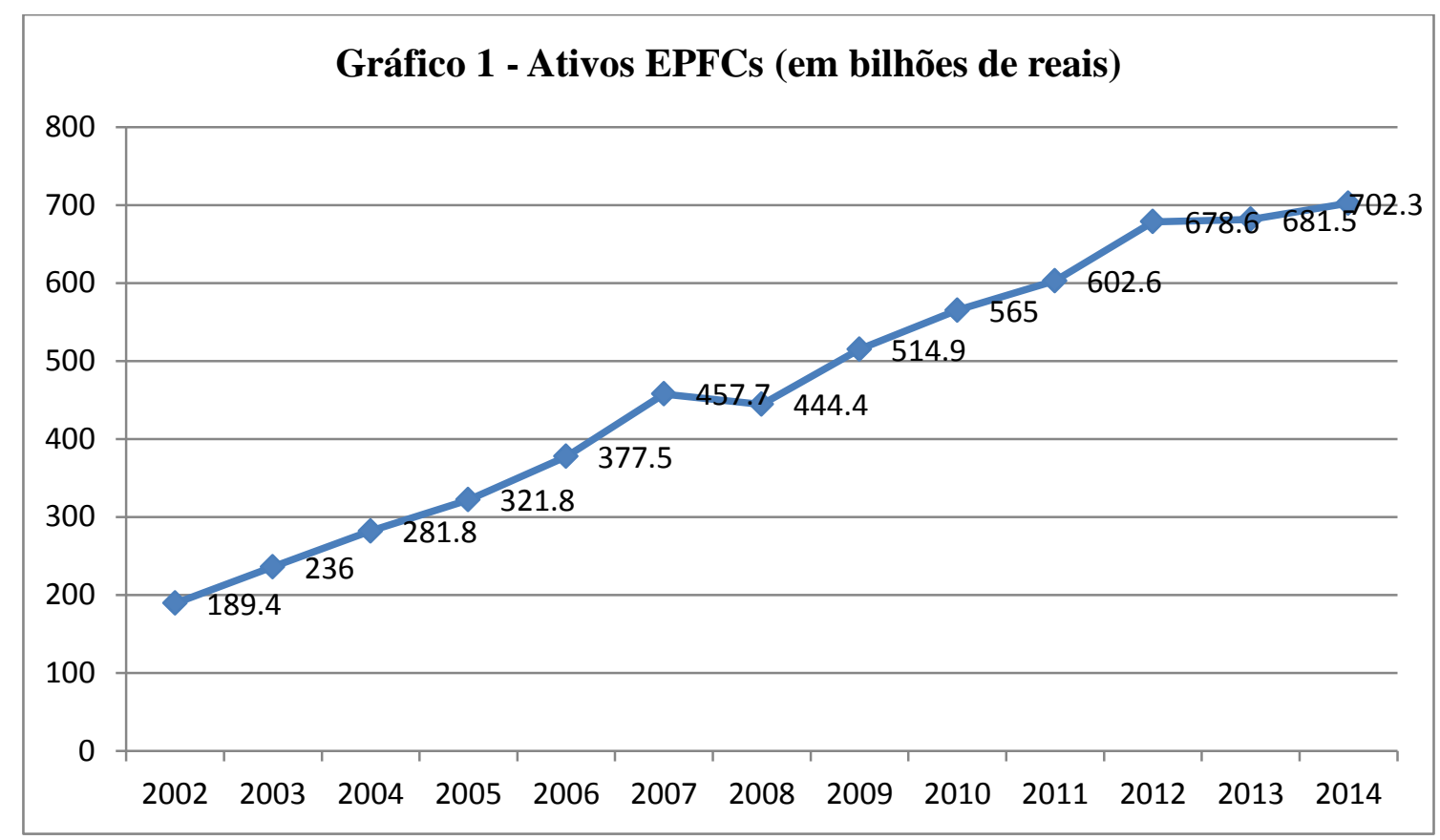

Elaboração própria. Fonte: PREVIC e ABRAPP. ${ }^{304}$

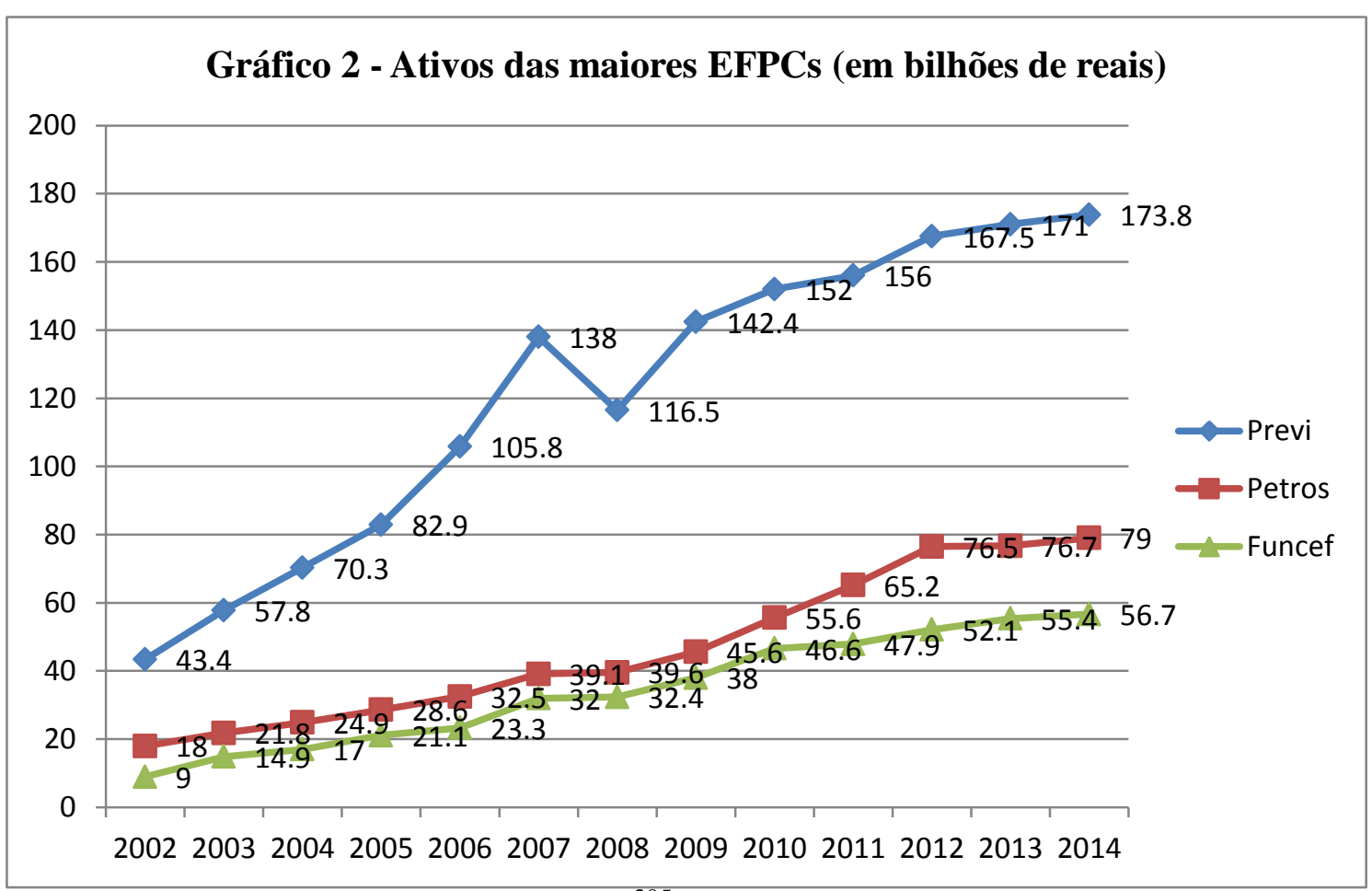

Elaboração própria. Fonte: PREVIC e ABRAPP. ${ }^{305}$

\footnotetext{
${ }^{304}$ Dados extraídos dos informes estatísticos destas entidades. Os valores referem-se a dezembro de cada ano. Para 2014, os dados são do mês de junho, último com estatísticas disponíveis. Disponível em: 〈http://www.previdencia.gov.br/wp-content/uploads/2014/09/2-trim-2014.pdf > $<$ http://www.abrapp.org.br/Consolidados/Forms/AllItems.aspx $>$. Acesso em 23.11.2014.

${ }^{305}$ Dados extraídos dos informes estatísticos destas entidades. Os valores referem-se a dezembro de cada ano. Para 2014, os dados são do mês de junho, último com estatísticas disponíveis. Disponível em: <http://www.previdencia.gov.br/wp-content/uploads/2014/09/2-trim-2014.pdf > $<$ http://www.abrapp.org.br/Consolidados/Forms/AllItems.aspx >. Acesso em 23.11.2014.
} 
No que se refere à participação dos fundos de pensão nas maiores empresas brasileiras, Lazzarinni $^{306}$ mostra que esta fatia está longe de ser desprezível e que aumentou sensivelmente entre os anos de 1996 e 2009.

\begin{tabular}{|l|l|l|}
\hline \multicolumn{3}{|l|}{ Tabela 6-Empresas com participação paraestatal } \\
\hline Ano & Grandes empresas pesquisadas & Participação paraestatal \\
\hline $\mathbf{1 9 9 6}$ & 516 & 72 \\
\hline $\mathbf{2 0 0 3}$ & 494 & 95 \\
\hline $\mathbf{2 0 0 9}$ & 624 & 119 \\
\hline
\end{tabular}

Elaboração própria. Dados de Lazzarinni apud Costa. O levantamento do autor incluiu todas as empresas de capital aberto e as maiores de capital fechado.

Alguns exemplos recentes de negociações e empreendimentos são significativos da ação articulada do Estado via fundos de pensão das estatais com o setor privado e apontam para uma forma de atuação do Estado no domínio econômico próxima daquela apontada por Nogueira da Costa e Mazzucato. Vejamos, então, os casos Sete Brasil, Vale e Invepar.

\section{Caso Sete Brasil}

A descoberta de vultosas reservas de petróleo na camada "pré-sal" em 2007, conjugada com a política de conteúdo local adotada pelo governo federal para o setor de petróleo e gás, fizeram surgir a demanda por parte da Petrobrás da construção de sondas de perfuração marítima em solo nacional. Com isso, foi criada, em 2010, a Sete Brasil, sociedade anônima de capital fechado especializada em gestão ativos da indústria petrolífera.

A Sete Brasil opera da seguinte forma ${ }^{307}$ : firma contratos de afretamento ${ }^{308}$ de longo prazo com a Petrobrás tendo como objeto 28 sondas de perfuração em águas ultraprofundas, que, por sua vez, têm a sua construção contratada com os estaleiros

\footnotetext{
${ }^{306}$ LAZZARINNI apud COSTA, Fernando Nogueira da. I Relatório de Pesquisa para o IPEA. PND 0592012, p. 61.

307 Informações do site institucional da empresa Sete Brasil. Disponível em $<$ http://ri.setebr.com/static/ptb/perfil-e-historico.asp?idioma=ptb $>$. Acesso em: 23.11.2014.

${ }^{308}$ Contratos de afretamento se caracterizam pela utilização (arrendamento) de uma embarcação marítima por um tempo determinado, no qual o proprietário dispõe de seu navio ao afretador, o qual assume a posse e o controle do mesmo, mediante pagamento. Disponível em: $<$ http://jus.com.br/artigos/4022/contratos-de-afretamento-e-transporte-no-direitomaritimo\#ixzz3Jwomk0mN>. Acesso em: 23.11.2014
} 
locais. Segundo a empresa, os contratos com a Petrobrás preveem uma receita de 89 bilhões de dólares (cerca de 200 bilhões de reais), e os investimentos para a construção das sondas demandam investimentos da ordem de 25 bilhões de dólares (cerca de 63 bilhões de reais).

Juntos, Previ, Petros e Funcef detêm 37,5\% do capital da empresa Sete Brasil, por meio de um Fundo de Investimentos em Participações chamado FIP Sondas ${ }^{309}$. Também participam do fundo Valia (EFPC dos empregados da Vale), além do Fundo de Investimento do FGTS, bancos como o BTG Pactual, o Santander e o Bradesco, e a Petrobrás (esta última com 5\% da composição acionária.

\section{Caso Vale}

A Companhia Vale do Rio Doce foi criada como estatal em 1942 e privatizada em 1997 durante o governo Fernando Henrique Cardoso. ${ }^{310}$ Atualmente denominada apenas de Vale, a composição acionária do seu capital ordinário (aquele com direito a participação nas tomadas de decisão) é a seguinte ${ }^{311}$ :

\begin{tabular}{|l|l|}
\hline \multicolumn{2}{|l|}{ Tabela 7 - Composição acionária da Vale } \\
\hline Acionista & Participação \\
\hline Valepar & $53,9 \%$ \\
\hline BNDESPAR & $6,5 \%$ \\
\hline Investidores brasileiros & $7,7 \%$ \\
\hline Investidores não-brasileiros & $31,9 \%$ \\
\hline
\end{tabular}

Elaboração Própria. Fonte: Vale.

A Valepar, acionista majoritária da Vale, é uma Sociedade de Propósito Específico (SPE), que foi constituída com o único objetivo de ter participação na Vale e que adquiriu o seu controle ainda em 1997, quando da venda dos ativos pelo Governo Brasileiro. Em dezembro/2013 312 , 49\% das ações da Valepar eram de titularidade do

\footnotetext{
${ }^{309}$ Ver adiante a discussão sobre os Fundos de Investimento em Participação.

${ }^{310}$ A participação dos fundos de pensão no processo de privatização dos anos 1990 será retomada adiante. 311 VALE. Shareholder Vale: outubro de 2014. Disponível em: <http://www.vale.com/brasil/PT/investors/company/shareholding-structure/Paginas/default.aspx $>$. Acesso em: 17.11.2014.

${ }^{312}$ As informações sobre acionistas da Valepar, da Litel Participações e do fundo de investimentos BB Carteira Ativa constam do Relatório Anual da Vale de 2013. Disponível em: <
} 
fundo de investimentos Litel Participações S/A, enquanto $11,51 \%$ pertenciam ao BNDESPAR. Também participam da Valepar investidores nacionais, como o Bradesco $(21,21 \%)$, e internacionais, como a Mitsui $(18,24 \%)$.

Por sua vez, o fundo de investimentos Litel é composto, em maioria absoluta, por fundos de investimentos controlados por EFPCs estatais (Previ, Petros, Funcef), com destaque para o fundo BB Carteira Ativa, 100\% de propriedade da Previ. Assim, com diversas mediações, o Estado brasileiro ainda pode manter decisiva influência sobre o controle sobre a Vale, conforme o fluxograma abaixo.

O controle do governo federal foi consumado em 2003, quando o BNDESPAR comprou 11,5\% da Valepar por 1,5 bilhão de reais, parcela que mantém até hoje, como vimos acima. Esta transação visava a evitar a venda das ações para a Mitsui, acionista minoritário da Valepar, que com isso superaria $25 \%$ de participação na SPE e consequentemente garantiria o direito de veto em decisões estratégicos da Vale. ${ }^{313}$ Ressaltamos que o governo brasileiro mantém ainda 12 ações golden share da Companhia, que lhe confere poderes de veto sobre decisões como mudança de nome, localização da sede e objeto social. ${ }^{314}$

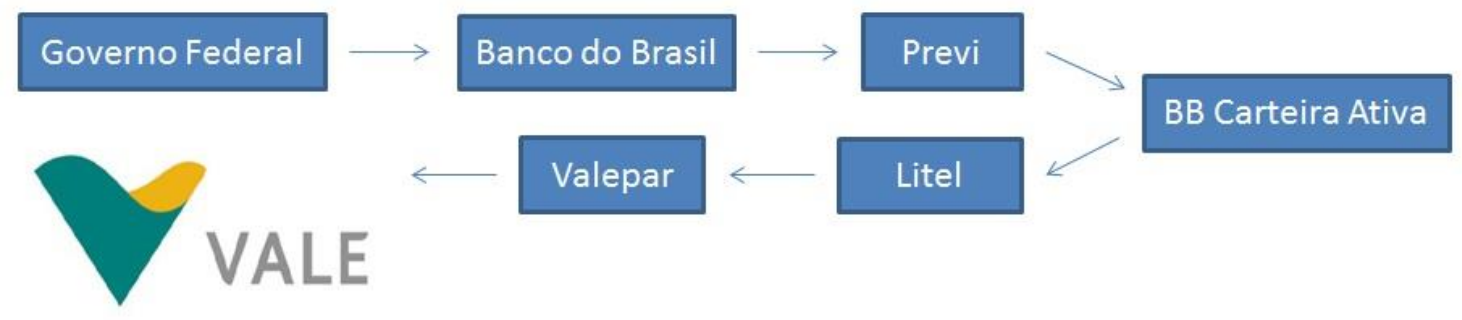

Elaboração própria. Diversas fontes.

O controle indireto do governo federal via participação minoritária com os fundos de pensão e o BNDESPAR ficou nítido em abril de 2011 quando da mudança do presidente da Vale. A troca contou com atuação do Poder Executivo, inclusive, pelo que

http://www.vale.com/PT/investors/Quarterly-results-reports/20F/20FDocs/20F 2013_p.pdf >. Acesso em: 17.11.2013.

313 COSTA, Fernando Nogueira da. Financiamento interno de longo prazo. In CALIXTRE, André Bojikian; BIANCARELLI, André Martins; CINTRA, Marcos Antonio Macedo. Presente e futuro do desenvolvimento brasileiro. IPEA. Brasília, 2014, p. 298.

${ }^{314}$ Ibidem. 
foi noticiado ${ }^{315}$, da própria Presidenta da República, Dilma Rousseff, que optou por um dirigente mais afinado com uma estratégia desenvolvimentista.

\section{Caso Invepar}

A Invepar ${ }^{316}$ é uma sociedade anônima de capital aberto, apesar de não ter suas ações negociadas em bolsa, composta por um grupo de 12 empresas concessionárias de serviço público em diversas regiões do país e no Peru, especialmente em rodovias, mobilidade urbana e aeroportos. Foi fundada em 2000, a partir da associação entre a construtora OAS e o fundo de pensão Previ. Naquele ano, assumiu duas concessões de rodovias: a LAMSA (Linha Amarela), no Rio de Janeiro, e a CLN (Concessionária Litoral Norte), na Bahia.

Posteriormente, no ano de 2012, o grupo de empresas recebeu um aporte de capital de 1,3 bilhões de reais da Petros e da Funcef, que, então, se tornaram acionistas. Com isso, a composição acionária da Invepar passou a ser a seguinte: PREVI - 25,56\%; FUNCEF - 25,00\% e PETROS - 25,00\% e Grupo OAS - 24,44\%. Também naquele ano, consórcio liderado ${ }^{317}$ pela Invepar venceu o leilão de concessão do maior aeroporto do país, o Aeroporto Internacional de Guarulhos. ${ }^{318}$ Hoje, este grupo de infraestrutura tem 12 concessões no país, conforme tabela abaixo, e experimentou uma valorização de $32,78 \%$ durante o ano de $2013 .^{319}$

\begin{tabular}{|l|l|l|}
\hline \multicolumn{3}{|c|}{ Tabela 8 - Empreendimentos grupo Invepar } \\
\hline Concessão & Participação & Localização \\
\hline Rodovias & \\
\hline
\end{tabular}

315 Conforme as reportagens: A guerra no banco começou na troca da presidência da vale, publicada em 29.02.2012 e disponível em: <http://www.estadao.com.br/noticias/impresso,a-guerra-no-banco-comecou-na-troca-da--presidencia-da-vale> e Dilma vetou escolha do Bradesco para a presidência da Vale, publicada em 06.04.2011 e disponível em: <http://www1.folha.uol.com.br/mercado/898851-dilmavetou-escolha-do-bradesco-para-a-presidencia-da-vale.shtml>. Ambas com acesso em 20.04.2012.

${ }^{316}$ Informações extraídas do site institucional da empresa: www.invepar.com.br, especialmente no seu Relatório Anual 2013. $\quad$ Disponível em: <http://www.invepar.com.br/midias/conteudo/pdf/Invepar_RA2013_PT_29set.pdf $>. \quad$ Acesso em 23.11.2014.

${ }^{317}$ A Infraero, empresa estatal que atua no setor, participou obrigatoriamente com $49 \%$ nos consórcios de concessão dos aeroportos. No que se refere aos parceiros privados, a Invepar é a maior acionista.

318 Fundos de pensão garantem controle estatal de aeroporto. Disponível em: <http://economia.estadao.com.br/noticias/geral,fundos-de-pensao-garantem-controle-estatal-deaeroporto, 131388e >. Acesso em: 23.11.2014.

$\begin{array}{ccccc}319 & \text { AUNCEF. } & \text { Relatório } & \text { Anual } & \text { Disponível }\end{array}$ 〈http://www.funcef.com.br/COSOC/relatorios/RAI2013/arquivos/relatorio-anual-2013.pdf >. Acesso em: 25.11.2014. 


\begin{tabular}{|l|c|l|}
\hline LAMSA (Linha Amarela) & $100 \%$ & Rio de Janeiro \\
\hline CLN (Concessionária Litoral Norte) & $91,5 \%$ & Bahia \\
\hline CART (Concessionária Auto Raposo Tavares) & $100 \%$ & São Paulo \\
\hline CBN (Concessionária Bahia Norte) & $50 \%$ & Bahia \\
\hline CRT (Concessionária Rio-Teresópolis) & $25 \%$ & Rio de Janeiro \\
\hline Complexo Viário e Logístico Suape & $50 \%$ & Pernambuco \\
\hline Rodovia BR-040 & $100 \%$ & $\begin{array}{l}\text { Goiás, Distrito Federal } \\
\text { e Minas Gerais }\end{array}$ \\
\hline Mobilidade Urbana & $100 \%$ & Rio de Janeiro \\
\hline MetrôRio & $100 \%$ & Lima, Peru \\
\hline Línea Amarilla S.A.C. & $33,3 \%$ & Rio de Janeiro \\
\hline Corredor Expresso Transolímpico & $100 \%$ & Rio de Janeiro \\
\hline Linha 4 do metrô do Rio de Janeiro & $24,49 \%$ & Rio de Janeiro \\
\hline VLT Carioca & $45,9 \%$ & São Paulo \\
\hline Aeroporto & \\
\hline Aeroporto de Guarulhos &
\end{tabular}

Elaboração própria. Fonte: Relatório Anual 2013 da Invepar.

\subsection{Carteira de Investimentos das EFPCs}

Vimos no capítulo anterior a classificação e os limites estabelecidos pela CVM para os investimentos das EFPCs, quais sejam: i) renda fixa; ii) renda variável; iii) investimentos estruturados; iv) investimentos no exterior; v) imóveis, e; vi) operações com participantes. Neste item, iremos analisar a composição da carteira dos fundos de pensão e sua distribuição, em cada um destes itens, das EFPCs, a partir da análise das três maiores entidades patrocinadas por estatais: Previ, Petros e Funcef. Os dados sobre a composição da carteira são extraídos dos relatórios destas três entidades, bem como dos informes estatísticos trimestrais da PREVIC e da Associação Brasileira das Entidades Fechadas de Previdência Complementar (ABRAPP).

Como vimos anteriormente, os fundos de pensão trabalham com a busca de valorização dos seus ativos para o pagamento de benefícios aos participantes. Ao mesmo tempo em que buscam essa valorização no mercado, em títulos públicos, privados, ações ou imóveis, precisam manter uma liquidez suficiente para pagamento de benefícios, e também por conta disso moderar o nível de risco a que estão expostos. 


\begin{tabular}{|l|l|l|}
\hline \multicolumn{4}{|c|}{ Tabela 9- Composição dos investimentos das EFPCs - Junho/2014 } \\
\hline Investimentos & R\$(bilhões) & Percentual \\
\hline Renda Fixa & 417,158 & $62,5 \%$ \\
\hline Títulos Públicos & 78,195 & $11,7 \%$ \\
\hline Créditos Privados e Depósitos & 26,680 & $4,0 \%$ \\
\hline Sociedades de Propósito Específico & 0,187 & $0,0 \%$ \\
\hline Fundos de Investimentos $-R F$ & 312,095 & $46,7 \%$ \\
\hline Renda Variável & 179,731 & $26,9 \%$ \\
\hline Ações & 78,697 & $11,8 \%$ \\
\hline Fundos de Investimento - RV & 101,034 & $15,1 \%$ \\
\hline Investimentos Estruturados & 21,205 & $3,2 \%$ \\
\hline Empresas Emergentes & 0,341 & $0,1 \%$ \\
\hline Participações & 18,541 & $2,8 \%$ \\
\hline Fundo Imobiliário & 2,323 & $0,3 \%$ \\
\hline Investimentos no Exterior & 0,374 & $0,1 \%$ \\
\hline Imóveis & 29,261 & $4,4 \%$ \\
\hline Operações com participantes & 18,244 & $2,7 \%$ \\
\hline Outros & 1,889 & $0,3 \%$ \\
\hline Total & 667,862 & $100,0 \%$ \\
\hline
\end{tabular}

Elaboração Própria. Fonte: APRAPP. 


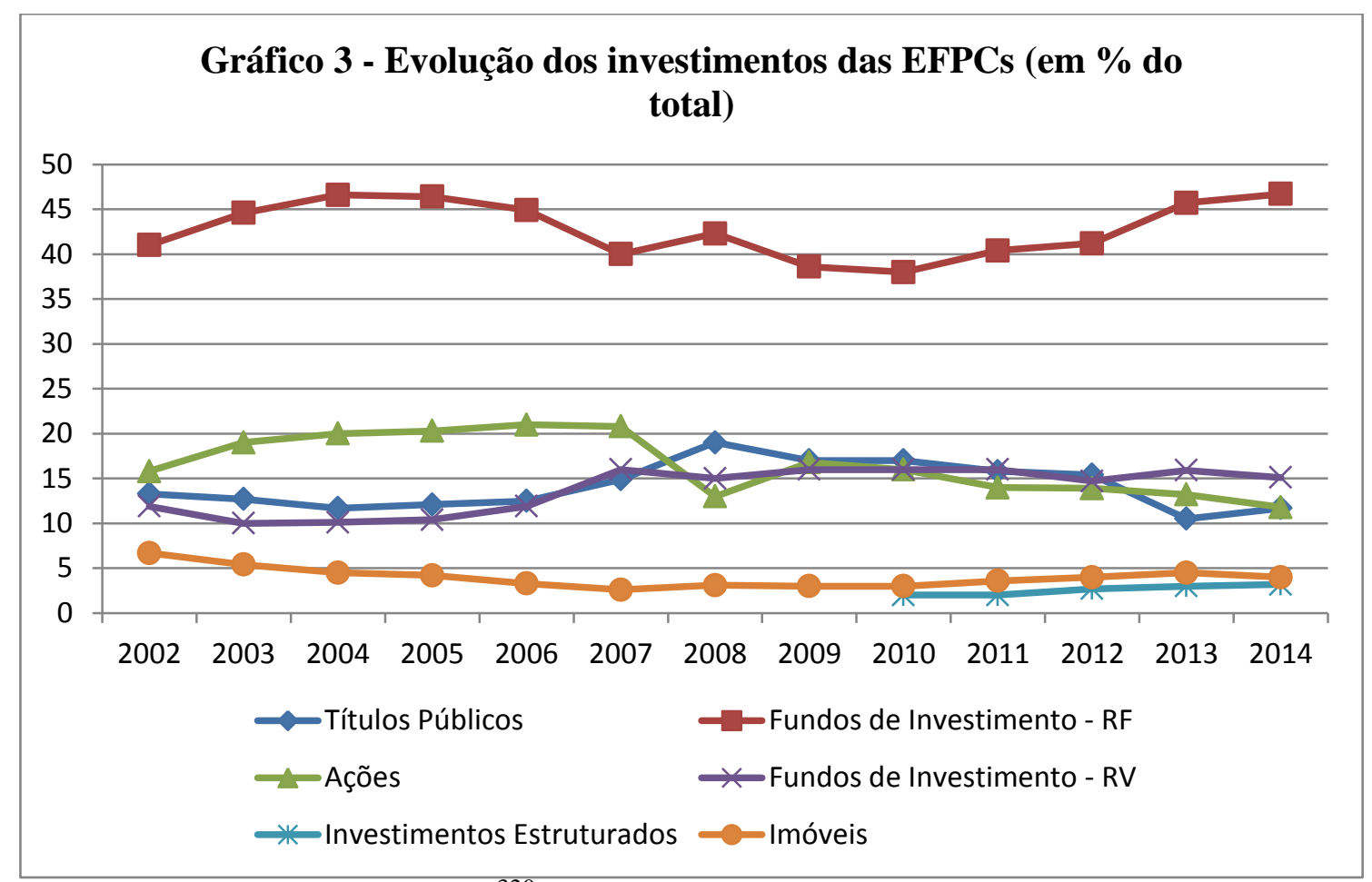

Elaboração própria. Fonte: ABRAPP. ${ }^{320}$

As aplicações em renda fixa constituem a maioria dos investimentos das EFPCs. Em Junho/2014, totalizavam 417,1 bilhões de reais, representando 62,5\% das carteiras. Esta proporção se mantém relativamente constante nos últimos 6 anos, apesar de ter experimentado aumento sensível em 2008, ano da crise financeira.

Parcela considerável destes investimentos em renda fixa é composta por títulos da dívida pública, tanto de forma direta, ou por meio de fundos de investimento em renda fixa. Inclusive, estima-se que quase a totalidade destes fundos seja composta por papéis da dívida. ${ }^{321}$ Isso porque, os títulos públicos são as aplicações mais tradicionais entre todas as existentes nos mercados financeiros, e tornam-se atraentes por sua liquidez, rentabilidade previsível e segurança. ${ }^{322}$ Adicionalmente, no Brasil a dívida pública torna-se ainda mais atrativa aos investidores pelo seu elevado nível de remuneração, dado que o Brasil tem ostentado taxas básicas de juros dentre as maiores do mundo, apesar da recente trajetória de baixa.

\footnotetext{
320 Até a Resolução CMN 3729/2009, os investimentos em fundos imobiliários eram computados na categoria Imóveis. Posteriormente, passaram a ser contabilizados na categoria Investimentos Estruturados. 321 INSTITUTO DE PESQUISA ECONOMICA APLICADA. Estado, instituições e democracia: desenvolvimento. Livro 9, Volume 3. Ipea, Brasília, 2010, pp. 652-653.

${ }^{322}$ PEREIRA, Francisco; MIRANDA, Rogério Boueri; SILVA, Marly Matias. Os fundos de pensão como geradores de poupança interna. Texto para discussão 480, IPEA. Maio de 1997, pp. 25-27.
} 
Durante a crise da dívida da década de 1980, os fundos de pensão, sobretudo aqueles patrocinados por estatais, foram obrigados a adquirir títulos da dívida pública para financiar o Estado brasileiro, que, por sua vez, chegou a proibir a venda destes papéis, especialmente aqueles de rentabilidade e negociabilidade duvidosa. ${ }^{323}$ Lembramos, ainda, que até 1994 o Estado continuava obrigando as EFPCs a manterem títulos da dívida pública em carteira, por meio do órgão regulador, o Conselho Monetário Nacional.

Contudo, mesmo após a extinção da obrigatoriedade, a dívida pública segue exercendo papel central na carteira dos fundos de pensão. Uma explicação para isso pode ser a "falta de opção" nos mercados de crédito e de capitais, ou também numa tendência conservadora dos administradores de fundo, dado que a liquidez, o menor risco e a remuneração próxima ou superior à taxa atuarial fazem dos títulos públicos uma opção quase que natural. $^{324}$

Todavia, a distribuição dos investimentos em renda fixa não é uniforme ou homogênea entre as EFPCs. O consolidado estatístico da ABRAPP mostra que quanto maior a entidade, maior é o percentual de investimentos alocados fora das opções da renda fixa. ${ }^{325}$ Isso pode, por um lado, ser devido ao fato de que os fundos médios e grandes, devido ao maior volume de recursos, têm também maior oportunidade para diversificalos, compondo sua carteira com ativos que não poderiam ser objeto de investimento por EFPCs menores, além de fornecer mais estrutura a equipes próprias de análise de financiamento. ${ }^{326}$

Por outro lado, ao conferirmos o argumento com a composição da carteira dos dois maiores fundos de pensão com patrimônio público, vemos que este não se verifica, pois mesmo sendo EFPCs de grande porte, a Fundação CESP e a Fundação Itau Unibanco alocam a maior parte de seus recursos em renda fixa, sendo este percentual de $74,80 \%$

\footnotetext{
323 MATIJASCIC. Milko. Fundos de pensão e rearticulação da economia brasileira. Campinas: UNICAMP, 1994, pp. 11-12.

${ }^{324}$ PEREIRA, Francisco; MIRANDA, Rogério Boueri; SILVA, Marly Matias. Os fundos de pensão como geradores de poupança interna. Texto para discussão 480, IPEA. Maio de 1997, p. 26; e INSTITUTO DE PESQUISA ECONOMICA APLICADA. Estado, instituições e democracia: desenvolvimento. Livro 9, Volume 3. Ipea, Brasília, 2010, p. 653.

${ }_{325}$ ABRAPP. Consolidado estatístico Junho/2014, p. 4.

${ }^{326}$ INSTITUTO DE PESQUISA ECONOMICA APLICADA, op. cit., p. 655.
} 
no caso da Fundação $\mathrm{CESP}^{327}$. No que se refere à Fundação Itaú Unibanco, os percentuais variam entre $77,55 \%$ e $100 \%$ de alocação em renda fixa, conforme o Plano de Benefícios ${ }^{328}$.

Ao contrário, as EFPCs patrocinadas pelas estatais e estudadas neste trabalho têm uma composição da carteira por tipo de investimento diferente. Vejamos os dados.

\begin{tabular}{|l|r|r|r|r|}
\hline \multicolumn{5}{|c|}{$\begin{array}{c}\text { Tabela 10 - Composição carteira Previ por classe de investimento (em bilhões de } \\
\text { reais) }\end{array}$} \\
\hline Investimentos & Plano 1 & Previ Futuro & \multicolumn{1}{c|}{ TOTAL } & \multicolumn{1}{c|}{$\%$} \\
\hline Renda Fixa & 52,02 & 2,679 & 54,699 & $31,64 \%$ \\
\hline Renda Variável & 99,401 & 1,848 & 101,249 & $58,56 \%$ \\
\hline Imóveis & 9,308 & 0,127 & 9,435 & $5,46 \%$ \\
\hline Operações com Participantes & 5,703 & 0,606 & 6,309 & $3,65 \%$ \\
\hline Investimentos Estruturados & 0,987 & 0,099 & 1,086 & $0,63 \%$ \\
\hline Investimentos no Exterior & 0,073 & 0,008 & 0,081 & $0,05 \%$ \\
\hline Outros & 0,029 & 0 & 0,029 & $0,02 \%$ \\
\hline Total Investimentos & 167,524 & 5,37 & 172,894 & $100,00 \%$ \\
\hline
\end{tabular}

Elaboração Própria. Fonte: Previ. ${ }^{329}$

\begin{tabular}{|l|r|r|}
\hline \multicolumn{3}{|c|}{$\begin{array}{l}\text { Tabela 11 - Composição carteira Petros por classe } \\
\text { de investimento (em bilhões de reais) }\end{array}$} \\
\hline Investimentos & \multicolumn{1}{|c|}{ TOTAL } & \multicolumn{1}{l|}{$\%$} \\
\hline Renda Fixa & 27,97 & $42,33 \%$ \\
\hline Renda Variável & 27,667 & $41,87 \%$ \\
\hline Imóveis & 4,056 & $6,14 \%$ \\
\hline Operações com Participantes & 3,735 & $5,65 \%$ \\
\hline Investimentos Estruturados & 2,048 & $3,10 \%$ \\
\hline Outros & 0,596 & $0,90 \%$ \\
\hline Total Investimentos & 66,075 & $100,00 \%$ \\
\hline
\end{tabular}

Elaboração própria. Fonte: Petros. ${ }^{330}$

327 Relatório Anual de Informações 2013. Disponível em < http://redecred.prevcesp.com.br/redecredenciada/iframe institucional_Portal/2013/FUNDACAOCESP.pd f >. Acesso em: 14.12.2014.

$\begin{array}{cccc}328 & \text { Relatório } & \text { Anual } 2013 . & \text { Disponível }\end{array}$ http://www.fundacaoitauunibanco.com.br/documentos/relatorios/relatorio_anual_2013.pdf $>$. Acesso em: 14.12.2014.

${ }^{329}$ Plano 1 e Previ Futuro são os dois planos de benefícios administrados pela Previ. Dados disponíveis em: 〈http://www.previ.com.br/investimentos/demonstrativos/>. Acesso em 25.11.2014.

330 Números de dezembro de 2013 (não há relatório posterior disponível). A Petros é um fundo multipatrocinado, ou seja, possui diversas empresas patrocinadoras (embora a maior seja a Petrobrás), boa parte delas subsidiárias da estatal de petróleo. Em virtude disso, o fundo de pensão possui grande 


\begin{tabular}{l} 
Tabela 12 - Composição carteira Funcef por classe de investimento (em bilhões de \\
reais) \\
\hline
\end{tabular}

Elaboração própria. Fonte: Funcef. ${ }^{331}$

De fato, chama atenção a grande diferença existente entre a composição destas carteiras e o consolidado geral das EFPCs no Brasil, especialmente no que diz respeito à concentração de ativos fora da renda fixa. Estes três fundos de pensão concentram $55,6 \%$ do total de investimentos das EFPCs, como já vimos. Entretanto, no que se refere aos investimentos em renda variável e aos investimentos estruturados temos uma concentração que está em torno de $75 \% .{ }^{332}$ A título de comparação, o Funcesp, maior fundo de pensão privado do país, aloca $75,8 \%$ dos seus investimentos em renda fixa. ${ }^{333}$ Chama atenção, ainda, a alta participação relativa - e também em termos absolutos dos investimentos estruturados na carteira da Funcef. Estes dados nos mostram que do total da poupança previdenciária das entidades fechadas que efetivamente contribui para a formação de funding, e que atua como capitalista no Brasil, três quartos estão nos grandes fundos federais. Isso se deve, por óbvio, ao tamanho destes fundos, mas também às opções explicitadas nas políticas de investimento dos planos de benefícios dessas três EFPCs.

quantidade de planos de benefícios. Daí a nossa opção por exibir os números totais consolidados. O relatório não informa investimentos no exterior. Demonstrativo de Investimento por Plano - Petros 2013. Disponível em: <https://www.petros.com.br/PortalPetros/faces/Petros/invs/dem?_adf.ctrl$\underline{\text { state }}=113 \mathrm{gb} 4 \times n 3 \mathrm{e} 4 \&$ afrLoop $=765848212130301>$. Acesso em: 25.11.2015.

${ }^{331}$ Informações extraídas dos Relatórios de Enquadramento de Investimento dos três planos de benefícios da Funcef: Novo Plano, REB e REG/Regplan. Os dados são de dezembro/2013, data dos últimos relatórios anuais publicizados. Disponíveis em: <http://www.funcef.com.br/COSOC/relatorios/RAI2013/seu-plano/novo-plano/politica-deinvestimento.html >; <http://www.funcef.com.br/COSOC/relatorios/RAI2013/seu-plano/reb/politica-deinvestimento.html $>; \quad<$ http://www.funcef.com.br/COSOC/relatorios/RAI2013/seu-plano/regreplan/modalidade-nao-saldada/politica-de-investimento.html >. Acesso em: 25.11.2015.

${ }^{332}$ Esta proporção não é exata, pois os dados extraídos sobre a Petros e a Funcef para este trabalho datam de dezembro/2013, enquanto os dados da Previ são de setembro/2014 e os números para o conjunto das EFPCs de junho/2014.

${ }^{333}$ Disponível em <http://www.prevcesp.com.br/wps/portal/Tema2013/Investimento\#tabs5 >. Acesso em: 26.11.2014. 
Com efeito, a política de investimento do plano de benefícios Plano 1 da Previ ${ }^{334}$ para o ano de 2014 estabelecia um piso de 53,52\% e um teto de $61,52 \%$ de renda variável e estabelece um limite máximo de 35,62\% de alocação em renda fixa, o que caracteriza uma carteira arrojada. Todavia, é relativamente tímida a política de investimento no que tange à categoria dos investimentos estruturados, que podem representar no máximo 1,5\% da carteira. Já no plano Previ Futuro, a política de investimentos ${ }^{335}$ é menos arrojada, prevendo máximo de 50\% da carteira em renda variável e de $95 \%$ em renda fixa, com um espaço um pouco maior para os investimentos estruturados (máximo de 5\%, sendo no mínimo 90\% do segmento em Private Equity).

Os "investimentos estruturados", como vimos anteriormente e retomaremos adiante, são uma categoria relevante que abrange os Fundos de Investimento em Participação Private Equity, os Fundos de Investimento em Empresas Emergentes - Venture Capital e os Fundos Imobiliários, podendo se constituir numa alternativa interessante para investimento em setores estratégicos que demandam alta mobilização de recursos e em inovação.

No caso da Petros, a política de investimentos apresenta bastante variação de acordo com o fluxo de caixa e grau de maturação de cada um dos seus planos de benefícios ${ }^{336}$, chegando a estabelecer um máximo de $60 \%$ de renda fixa e $50 \%$ de variável no Plano Petros Sistema Petrobrás (política de investimentos mais arrojada) e mínimo de $90 \%$ de renda fixa em seus planos de Contribuição Definida.

Por sua vez, a Funcef disponibiliza os percentuais de alocação da sua política de investimento dos planos de benefícios apenas para os participantes do fundo. ${ }^{337}$ Todavia, sinaliza que fará um retorno maior aos títulos públicos nos próximos 4 anos, como consequência da "mudança de cenário de curto prazo, com elevação dos juros reais para patamares acima da meta atuarial" ${ }^{\text {338 }}$, o que difere de informações veiculadas

\footnotetext{
334 Dados disponíveis em: <http://www.previ.com.br/investimentos/demonstrativos/>. Acesso em 25.11.2014.

${ }^{335}$ Dados disponíveis em: <http://www.previ.com.br/investimentos/demonstrativos/>. Acesso em 25.11.2014.

336 PETROS. Políticas de Investimentos 2014-2018. Disponível em: <https://www.petros.com.br/PortalPetros/faces/Petros/invs/pol? adf.ctrlstate=ajtkfuf6n $4 \&$ afrLoop $=157182985130298>$. Acesso em: 26.11.2014.

337 Conforme nota publicada em <http://www.funcef.com.br/noticias/politicas-de-investimentos-20142018-1.htm>. Acesso em: 26.11.2014.

${ }^{338}$ REVISTA FUNCEF, nº7, pp. 10-12.
} 
na imprensa em $2013^{339}$, nas quais o presidente da entidade afirmava a meta de chegar a 45\% de alocação em renda variável e 15\% em investimentos estruturados até 2017.

\subsection{Participação das EFPCs em empresas e empreendimentos}

As Entidades Fechadas de Previdência Complementar possuem um amplo portfólio de participações em empresas e empreendimentos, com importante capilaridade na economia brasileira. O Relatório Social de 2010 da ABRAPP $^{340}$ mostra que o conjunto dos fundos de pensão brasileiros (sem distinção por tipo de patrocinador) está presente em empresas nos mais diversos setores da economia, com destaque para:

- Alimentos, bebidas e fumo: Ambev, Perdigão, Sadia e Souza Cruz.

- Automotivo: FrasLe, Kepler Weber e Randon.

- Bancos: Banco do Brasil, Banrisul, Bradesco e Itaú.

- Confecções e têxteis: Coteminas e Teka.

- Construção civil: Duratex e Mendes Júnior.

- Energia: Afluente, Baguari, Bahia PCH, Celesc, Celpe, Cemig, Coelba, Coelce, Cosern, CPFL Energia, Eletrobrás, Goiás Sul, GTD, Itapebi, NC Energia, Neo Energia, Proman, RGE, Termopernambuco e Tractebel.

- Imobiliário: Iguatemi e Jereissati Participações.

- Limpeza: Bombril

- Transporte: ALL, CLN, Embraer, Invepar, Lamsa, Opportrans, Ponta do Félix.

- Mecânica: Weg.

- Papel e celulose: Aracruz, Klabin, Suzano Papel e Celulose e Votorantim Celulose e Papel.

- Petróleo e Gás: Clep e Petrobras.

- Química e Petroquímica: Petroflex e Ultrapar.

- Siderurgia e metalurgia: Acesita, Caraíba Metais, CSN, Cia. Vale do Rio Doce, Eluma, Forjas, Taurus, Gerdau, Litel, Paranapanema, Tupy, Usiminas.

- Telecomunicações: Brasil Telecom, Contax, Fiago, Invitel, Jereissati Participações, La Fonte, Newtel, Solpart, Techold, Tele Norte Leste, Telemar, TIM, Vivo.

\footnotetext{
${ }^{339}$ VALOR ECONÔMICO. Funcef busca mais renda variável e investimentos estruturados. 05.04.2013. Disponível em: <http://www.valor.com.br/financas/3075738/funcef-busca-mais-renda-variavel-einvestimentos-estruturados >. Acesso em: 26.11.2014.

340 Disponível em: <http://www.abrapp.org.br/apoio/relatorio_social/relatorio3.html>. Acesso em: 27.11.2014.
} 
- Turismo e Lazer: Hopi Hari, Sauípe.

As EFPCs podem participar das empresas das seguintes formas: i) participação direta, com a aquisição de ações da companhia; ii) participação indireta, adquirindo cotas de fundos de investimento que manejam a compra e venda de ações no mercado, ou dos Fundos de Investimento em Participações (FIPs) - também conhecidos como fundos de Private Equity ou Venture Capital -, e Fundos de Investimento em Empresas Emergentes (FMIEEs) - Venture Capital.

Ainda, as empresas e fundos participados pelas EFPCs podem formar Sociedades de Propósito Específico (SPE), que são consórcios empresariais formados com uma única finalidade (estabelecida no seu consórcio social), geralmente relacionada a grandes projetos de engenharia e/ou à concessão de serviços públicos, especialmente concessões no modelo de Parceria Público Privada (PPP) (Lei 11.079/2004). Compõem o segmento de renda variável, conforme Resolução 3792/2009 da CVM.

Abaixo, tabelas com a participação acionária da Previ e da Petros. ${ }^{341}$

\begin{tabular}{|l|l|l|l|}
\hline \multicolumn{4}{|c|}{ Tabela 13- Empresas Participadas Previ } \\
\hline \multicolumn{1}{|c|}{ Empresas } & \% PREVI & \multicolumn{1}{c|}{ Empresas } & \% PREVI \\
\hline 521 Participações & 100,00 & Itausa & 2,56 \\
\hline Afluente Geração & 2,29 & JP Participações & 23,87 \\
\hline Afluente Transmissão & 2,29 & Jereissati Telecom & 19,78 \\
\hline Ambev & 2,77 & Kepler Weber & 17,47 \\
\hline America Latina Logística & 3,98 & Klabin & 0,07 \\
\hline Banco Do Brasil & 10,41 & Magazine Luiza & 2,37 \\
\hline Bradesco & 1,62 & Metalúrgica Gerdau S.A. & 1,62 \\
\hline BRF - Brasil Foods S.A. & 11,73 & Neoenergia S.A. & 49,01 \\
\hline Celesc & 14,46 & Newtel Part. & 14,36 \\
\hline Cemig & 0,37 & Oi S.A. & 0,88 \\
\hline Coelba & 2,29 & Paranapanema & 23,96 \\
\hline Cosern & 1,54 & Petrobras & 2,81 \\
\hline Cpfl Energia & 30,03 & Randon & 6,80 \\
\hline Embraer & 7,83 & Sauípe & 100,00 \\
\hline Fiago & 51,89 & Sete Brasil & $* *$ \\
\hline Fibria Celulose S.A. & 1,45 & Sul 116 Participações & 11,17 \\
\hline Forjas Taurus S.A. & 19,43 & Suzano Papel e Celulose S.A. & 0,95 \\
\hline Fras-Le & 22,50 & Telemar Participações & 3,13 \\
\hline Gerdau S.A. & 0,67 & Tupy & 27,99 \\
\hline Gtd Participações & $21,63 *$ & Ultrapar Part. & 5,77 \\
\hline
\end{tabular}

${ }^{341}$ Não foram encontrados fontes para as empresas participadas da Funcef. 


\begin{tabular}{|l|l|l|l|}
\hline Invepar & 25,56 & Usiminas & 5,87 \\
\hline Invitel Legacy & 19,99 & Vale & $15,15^{* * *}$ \\
\hline Itaú Unibanco Holding S.A. & 1,80 & Weg & 0,06 \\
\hline
\end{tabular}

Elaboração: Previ. ${ }^{342} *$ Reflete a participação direta $(1,99 \%)$ e indireta $(19,64 \%$ via fundo de investimentos). ** Participação via Fundo de Investimentos em Participações Sondas (FIP Sondas). *** Reflete a participação direta (Previ Futuro) e indireta (Plano1), considerando ações resgatáveis.

\begin{tabular}{|l|l|}
\hline \multicolumn{2}{|c|}{ Tabela 14 - Participações acionárias Petros (valores em milhões de reais) } \\
\hline ALL América Latina UNT 378,542 & Invitel Legacy ON 0,082 \\
\hline Brasil Ecodiesel ON 28,776 & Itausa PN 3.089,787 \\
\hline BRF - Brasil Foods ON 2.343,941 & JBS ON 237,045 \\
\hline Braskem ON 34,071 & Litel ON 0,001 \\
\hline Coelce PNA 83,983 Litel PNA & Litel PNA 0,002 \\
\hline Coteminas ON 13,949 & Log-In Logística ON 122,047 \\
\hline Coteminas PN 6,621 & Lupatech ON 137,856 \\
\hline CTX Participações ON 28,534 & Marcopolo PN 100,366 \\
\hline Estacionamento Cinelândia ON 2,514 & Newtel ON 2,286 \\
\hline Eucatex PN 8,826 & Paranapanema ON 188,887 \\
\hline Fiago ON 0,311 & Petrobras ON 914,341 \\
\hline Fras-le ON 44,070 & Petrobras PN 604,665 \\
\hline GTD ON 1,441 & Romi ON 101,734 \\
\hline GTD PN 1,340 & Telebras PN 0,288 \\
\hline Iguatemi ON 339,663 & Telebras Recibo PN 7,602 \\
\hline Inepar Energia ON 2,798 & Telesp ON 0,126 \\
\hline Inepar Energia PNA 4,820 & Telemar Participações ON 573,882 \\
\hline Invepar ON 217,402 & Totvs ON 52,829 \\
\hline Invepar PN 434,804 & Carteira Ativa II (Mellon) - FIA 4.738,396 \\
\hline
\end{tabular}

Fonte: Petros. 345

A Previ possui, ainda, forte entrada no segmento de shopping centers, detendo participação no Shopping Metrô Tatuapé e Shopping Center Morumbi (São Paulo), New York City Center (Rio de Janeiro) ParkShopping (Brasília), além de edifícios comerciais como o São Luiz Gonzaga e o Morumbi Office Tower (São Paulo). No ramo hoteleiro, a Previ é proprietária do complexo de Costa do Sauípe, litoral baiano. O grupo Iguatemi, por sua vez, tem a participação da Petros e da Previ, esta última por intermédio da Jereissati Participações.

342 Disponível em: <http://www.previ.com.br/investimentos/empresas-participadas/>. Acesso em: 26.11.2014.

${ }^{343}$ As ações classificadas como PN são ações preferenciais, enquanto as ON são ordinárias (com direito a voto).

${ }^{344}$ Fundo detentor de ações da Vale.

345 PETROS. Balanço Social 2010. Disponível em: < https://www.petros.com.br/cs/groups/public/documents/documento/y2lh/bf8y/ edisp/balanco_social_201 0.pdf > . Acesso em: 28.11.2014. 
Como se depreende da tabela, as empresas atuantes em setores regulados, que assumiram os serviços privatizados durante a década de 1990, possuem grande participação no portfólio dos fundos de pensão das estatais. Isso se deve à intensa participação destas entidades na compra de ativos à época. No setor de telefonia, esta atuação dos fundos desembocaria no que se chamou de maior disputa acionária da história com o banqueiro Daniel Dantas. ${ }^{346}$ Para Sérgio Rosa, acabou havendo, durante as privatizações uma inusitada convergência de interesses entre os dirigentes indicados pelo governo e aqueles ligados aos sindicatos, que seria um dos motivos que levaram à concentração da carteira da Previ em investimentos de renda variável:

Eu não estava aqui quando o portfólio foi montado [portfólio da Previ montado na década de 1990]. A maior parte dos investimentos ocorreu em função das privatizações (...). De um lado, havia os representantes do $\mathrm{BB}$ e do governo buscando contribuir para o processo de privatização, orientando o fundo a integrar os consórcios. Por outro lado, havia representantes dos participantes dentro da Previ com uma visão nacionalista, desenvolvimentista, dizendo: "já que vai privatizar, vamos entrar. Somos investidores de longo prazo, então, vamos ajudar essas empresas a não caírem na mão de qualquer um". 347

Também destacam-se as participações de Previ e Petros em companhias telefônicas e de logística, bem como a presença do grupo Neoenergia na carteira da Previ, controlador de empresas estaduais de energia privatizadas e detentor de participação na concessão da maior usina hidrelétrica em construção no país, Belo Monte, com o consórcio Norte Energia S/A, do qual também participam Petros e Funcef.

Em 2010, o consórcio venceu o leilão para construção e exploração do potencial hidrelétrico da UHE Belo Monte, estimado em 11.233,1 MW de potência e geração anual prevista de 38.790.156 $\mathrm{MWh}^{348} \mathrm{O}$ consórcio Norte Energia é liderado pelas empresas do grupo Eletrobrás, detentoras de 49,98\% das ações. A Neoenergia, empresa participada da Previ, tem 10\%, enquanto Petros e Funcef têm 10\% de participação cada uma no consórcio. A UHE Belo Monte é a terceira maior obra do Programa de

\footnotetext{
${ }^{346}$ Ver relato em <http://revistapiaui.estadao.com.br/edicao-35/vultos-brasileiros/sergio-rosa-e-o-mundodos-fundos $>$. Acesso em: 30.11.2014.

347 Disponível em: <http://www.contec.org.br/index.php/contec-online/informes-anteriores-geral/102outubro-2009/2248-2248>. Acesso em: 30.11.2014.

348 Disponível em: <http://norteenergiasa.com.br/site/portugues/norte-energia-s-a/>. Acesso em: 28.11.2014.
} 
Aceleração do Crescimento (PAC), com um valor total de investimento previsto de 28,9 bilhões de reais.

Dentre os maiores empreendimentos do PAC com participação das EFPCs patrocinadas por estatais, figura também a "Ferrovia Norte-Sul", que, em sua extensão total terá 1980 km. O trecho já concluído vai de Açailândia (MA) até Anápolis (GO). O trecho sul, incluído no $\mathrm{PAC}^{349}$, vai de Palmas até Estrela D’Oeste (SP) e compreende um investimento total de 6,9 bilhões de reais. A execução das obras é de responsabilidade da empresa estatal VALEC.

A participação dos fundos de pensão se dá por meio da Vale, que arrematou, em $2007^{350}$, o trecho que vai de Açailandia (MA) a Palmas (TO). Com a concessão, a empresa tornou-se responsável pela operação, conservação e melhoramentos da Ferrovia por 30 anos. Em 2012, foi criada a holding VLI (Valor da Logística Integrada $^{351}$ a partir dos ativos de logística da Vale. Os acionistas da VLI são Mitsui, FI-FGTS, Brookfield, além da própria Vale. ${ }^{352}$ A VLI opera as ferrovias que estão sob concessão da Vale, além de portos e terminais integrados de carga em todo o país.

Verifica-se, também, que Previ e Petros e Funcef ${ }^{353}$ detêm participação acionária na América Latina Logística (ALL), detentora de quatro concessões de ferrovias nas regiões Sudeste, Sul e Centro-Oeste, totalizando $13 \mathrm{mil} \mathrm{km}$, responsáveis pelo transporte especialmente de commodities agrícolas para alguns dos principais portos do país, como Santos, Paranaguá, Rio Grande e São Francisco do Sul. Na Embraer, terceira maior fabricante de jatos comerciais do mundo, a Previ vem diminuindo a sua participação, que já chegou a ser de $20 \%{ }^{354}$

\footnotetext{
${ }^{349}$ Disponível em: 〈http://www.pac.gov.br/obra/5309 e <http://www.pac.gov.br/obra/5311 >. Acesso em: 28.11.2014.

${ }^{350}$ FOLHA DE SÃO PAULO. Única interessada, Vale leva ferrovia Norte-Sul por 14 bi. Disponível em: $<$ http://www1.folha.uol.com.br/mercado/2007/10/333483-unica-interessada-vale-leva-ferrovia-norte-sulpor-r-14-bi.shtml>. Acesso em: 28.11.2014.

351 VALOR ECONÔMICO. Vale tira do papel VLI, sua empresa de logística. Disponível em: <http://www.valor.com.br/empresas/2889054/vale-tira-do-papel-vli-sua-empresa-de-logistica >. Acesso em: 28.11.2014.

${ }^{352}$ Disponível em: 〈http://www.vli-logistica.com/pt-br/conheca $>$. Acesso em: 28.11.2014.

353 Disponível em: <http://ri.all-logistica.com/all/web/conteudo pt.asp?idioma=0\&conta=28\&tipo=279 > Acesso em: 28.11.2014.

354 EXAME. Previ reduz participação na Embraer. Disponível em: <http://exame.abril.com.br/mercados/noticias/previ-reduz-participacao-na-embraer>. Acesso em: 30.11 .2014
} 
Já no setor de alimentos, percebemos que a Previ e a Petros são as duas maiores acionistas da BRF (Brasil Foods), com cerca de 12\% da composição acionária, cada uma. A BRF foi formada a partir da fusão entre Sadia e Perdigão em 2009 e hoje encontra-se entre as maiores empresas do mundo do ramo de alimentos, sendo responsável por $9 \%$ da exportação mundial de proteína animal. ${ }^{355}$ A companhia compõe, junto com a JBS Friboi e Mafrig ${ }^{356}$, as campeãs nacionais do setor.

Por sua vez, os Fundos de Investimento em Participação (FIPs) (Private Equity), são disciplinados pela Instrução da Comissão de Valores Mobiliários (CVM) no 391/2003. Trata-se de fundos que têm como ativos-alvo de seu investimento participações societárias em empresas de capital aberto ou fechado, ou ainda em cotas de outros fundos.

Sua especificidade está no fato de serem direcionados a investidores qualificados (art. $5^{\text {o }}$ da Instrução CVM 391/2001), quais sejam: i) instituições financeiras; ii) companhias seguradoras; iii) entidades abertas e fechadas de previdência complementar; iv) pessoas físicas ou jurídicas que possuam investimentos superiores a $\mathrm{R} \$ 300 \mathrm{mil}$, e; v) administradores autorizados pela CVM. ${ }^{357}$ Ainda conforme a Resolução, os FIPs devem exercer "efetiva influência na definição de sua política estratégica e na sua gestão, notadamente através da indicação de membros do Conselho de Administração" (art. $2^{\circ}$ ).

Os FIPs investem em empresas de grande porte com potencial de crescimento e em sua maioria sem capital aberto na bolsa de valores. ${ }^{358} \mathrm{O}$ segmento passa a atrair de forma mais intensa os fundos de pensão nos anos 2000, quando foi estruturado, com a participação dos fundos (inclusive os patrocinados por estatais - Previ, Petros, Funcef), e coordenação do BNDES, o Fundo Brasil Energia, para investimento em linhas de transmissão e ativos voltados à geração de energia. ${ }^{359}$

Os FIPs têm papel estratégico na estruturação de grandes investimentos em ativos de infraestrutura ou ainda de porte industrial.

\footnotetext{
${ }^{355}$ Disponível em: 〈http://www.brf-global.com/brasil/sobre-brf/quem-somos-nossa-historia >. Acesso em: 28.11.2014.

${ }^{356}$ A JBS Friboi conta com pequeno aporte acionário da Petros. Entretanto, destaca-se nesta companhia e também na Mafrig, a participação acionária do BNDESPar: 24,6\% e 19,6\%, respectivamente.

${ }^{357}$ Conforme art. 109 da Instrução CVM no 409, de 18 de agosto de 2004.

358 COSTA, Fernando Nogueira da. Financiamento interno de longo prazo. In CALIXTRE, André Bojikian; BIANCARELlI, André Martins; CINTRA, Marcos Antonio Macedo. Presente e futuro do desenvolvimento brasileiro. IPEA. Brasília, 2014, p. 319.

359 INSTITUTO DE PESQUISA ECONOMICA APLICADA. Estado, instituições e democracia: desenvolvimento. Livro 9, Volume 3. Ipea, Brasília, 2010, p. 660.
} 
Não destinado a adquirir a totalidade das ações ou cotas, o FIP pode ser um parceiro estratégico na composição de uma estrutura de financiamento em um determinado ativo, na medida em que sua permanência no mesmo ativo pode ser tão longa quanto a duração prevista no FIP, prevista em regulamento. 360

Já os FMIEEs (Venture Capital) são regidos pela Instrução CVM no 209/1994 e destinam-se prioritariamente a empresas novas e de pequeno porte com forte conteúdo tecnológico e de inovação. Essas companhias, chamadas emergentes devem ter um faturamento líquido anual de, no máximo, 150 mil reais. É considerado um investimento de alto risco, dada a elevada mortalidade dessas empresas, mas possui alto potencial de valorização. ${ }^{361}$

Dados da Associação Brasileira de Private Equity e Venture Capital (ABVCAP) ${ }^{362}$ mostram um crescimento relevante $(58 \%)$ do total de investimentos nestas duas modalidades, em dois anos. Em 2011, o capital comprometido era de 63,5 bilhões de reais, passando para 100,2 bilhões em 2013. A Previ aponta que obteve rentabilidade alta nestes investimentos em 2013, sendo 30,9\% no Plano Previ Futuro e 20,6\% no Plano 1.363

Todavia, conforme vimos no item anterior deste capítulo, os investimentos estruturados, compostos também por FIP e FMIEE, têm participação ainda baixa na carteira da Previ (1\%), bem como da Petros (3\%). Esta classe de investimento tem maior participação na carteira da Funcef (cerca de $8 \%)^{364}$, mesmo que distante do limite de $20 \%$ estabelecido pela Resolução no 3.792/2009 da CVM. Ainda assim, o conjunto dos fundos de pensão responde por nada menos que $40 \%$ do total do capital investido nos FIPs e FMIEEs. ${ }^{365}$ Destaca-se dentre estes investimentos o FIP Sondas, com 6,5 bilhões de reais de

360 INSTITUTO DE PESQUISA ECONOMICA APLICADA. Estado, instituições e democracia: desenvolvimento. Livro 9, Volume 3. Ipea, Brasília, 2010, p. 661.

${ }^{361}$ Ibidem, pp. 661-662.

${ }^{362}$ ABVCAP e KPMG. Consolidação de dados da indústria de Private Equity e Venture Capital no Brasil. 2014. Disponível em <http://www.abvcap.com.br/Download/Estudos/2716.pdf>. Acesso em: 28.11.2014.

363 PREVI, Relatório 2013, em: $<$ http://www.previ.com.br/quemsomos/relatorio2013/home.html >. Acesso em: 28.11.2014.

364 A Funcef pretende ampliar este percentual para $15 \%$ até 2019. Ver: <http://www.valor.com.br/financas/3518896/fundo-de-pensao-quer-ampliar-fatia-em-private-equity $>$. Acesso em: 30.11.2014.

${ }^{365}$ ABVCAP e KPMG, op. cit.. 
patrimônio líquido (sendo $75 \%$ dos EFPCs patrocinados pelas estatais), que serve como funding para a Sete Brasil, companhia a que nos referimos no item anterior.

A título exemplificativo ${ }^{366}$, elencamos na tabela abaixo alguns FIPs dos quais participam os três maiores fundos de pensão do país:

\begin{tabular}{|l|l|l|}
\hline \multicolumn{3}{|c|}{ Tabela 15 - FIPs participados por Previ, Petros e Funcef } \\
\hline FIP & Patrimônio Líquido & EFPCs participantes \\
\hline InfraBrasil & $1,08 \mathrm{bi}$ & Previ, Petros Funcef \\
\hline Brasil Agronegócios & $310 \mathrm{mi}$ & Previ, Petros \\
\hline Terra Viva & $285 \mathrm{mi}$ & Previ, Petros, Funcef \\
\hline Brasil Energia & $1,3 \mathrm{bi}$ & Petros \\
\hline Fundo Florestal Brasil & $1,5 \mathrm{bi}$ & Petros, Funcef \\
\hline
\end{tabular}

Elaboração própria. Fontes: $\operatorname{Jardim}^{367}$ e CVM.

No que ser refere à rentabilidade dos planos de benefício, objetivo das Entidades Fechadas de Previdência Complementar, elas ficaram abaixo da meta atuarial em 2013 - um ano ruim especialmente para a bolsa de valores. Entretanto, se considerados os resultados da última década, a conta é positiva. Entre 2004 e 2013, a Previ acumulou rendimento de $374 \%$, quase o dobro da meta atuarial de $199 \%{ }^{368}$. Já a Petros, no mesmo período acumulou rendimento de $295,36 \%$, contra $221,23 \%$ da meta ${ }^{369}$. Por sua vez, a Funcef teve rentabilidade de $310 \%$ entre 2003 e 2011, vis a vis uma meta de $154,29 \%{ }^{370}$.

\subsection{Dirigentes das EFPCs}

Vimos no capítulo 2 deste trabalho que a estrutura de governança estabelecida pela LC 108/2001 para as EFPCs prevê a participação paritária de representantes indicados pela

\footnotetext{
${ }^{366}$ As EFPCs em estudo não disponibilizam em seus balanços a relação de FIPs nos quais investem, e a CVM também não publiciza esta informação. A tabela com o elenco de FIPs participados pelos fundos tem como fonte o estudo de Maria A. Chaves Jardim (ver nota abaixo).

367 JARDIM, Maria A. Chaves. Fundos de Pensão: o investimento dos fundos de pensão durante o governo Lula, a construção das crenças de responsabilidade social e sustentabilidade e o recente interesse por investimentos na Amazônia brasileira. Relatório de pesquisa apresentado ao Inesc. 2010.

368 Disponível em: <http://www.valor.com.br/financas/3440480/em-ano-ruim-previ-supera-bolsa-mas$\frac{\text { nao-cumpre-meta }}{369}$. Acesso em: 30.11.2014.

<https://www.petros.com.br/PortalPetros/faces/Petros/arqnot/not? afrLoop=260842438431981\&content= WCC017033\& afrWindowMode $=0 \&$ adf.ctrl-state=17xjc3xz96 4 $>$. Acesso em: 30.11.2014.

$370 \quad$ Disponível em:

<http://www.funcef.com.br/flipbook/Revista_Especial_Maio2011/files/revista_alterada_18maio_final.pdf >. Acesso em: 30.11.2014.
} 
patrocinadora e pelos participantes no Conselho Deliberativo, com voto de minerva para o presidente do Conselho, indicado pela patrocinadora. Por sua vez, o Conselho Deliberativo tem como atribuição indicar os membros da Diretoria Executiva da entidade, instância de governança responsável por sua administração (art. 13, VI, e arts. 19 a 23 da LC 108/2001).

Neste item, analisaremos o perfil dos diretores-presidentes das Diretorias Executivas dos três grandes fundos de pensão brasileiros e suas declarações públicas sobre as políticas de investimento das EFPCs. Estes dirigentes são os "CEO" das entidades, e verificar a sua origem, formação e atuação pode nos fornecer indícios que respondam à hipótese formulada no começo deste trabalho. O recorte temporal utilizado aqui é a LC 108/2001. Ou seja, pesquisamos os presidentes dos fundos de pensão que estavam no cargo quando da entrada em vigor da atual regulação da previdência complementar fechada, e também aqueles cujos mandatos iniciaram após a entrada em vigor da referida lei.

Nas tabelas a seguir, elencamos as informações referentes ao currículo de cada um dos presidentes das EFPCs. As informações nelas contidas foram obtidas através dos currículos e perfis publicados nos sítios eletrônicos de órgãos oficiais, dos próprios fundos de pensão, bem como de jornais e meios de grande circulação nacional.

\begin{tabular}{|c|}
\hline Quadro 1 - Presidentes Previ \\
\hline Luiz Tarquínio Sardinha Ferro (1998-2002) \\
\hline $\begin{array}{l}\text { - Pós-graduado em Economia. } \\
\text { - Superintendente de Finanças do Banco do Brasil entre } 1996 \text { e } 1998 . \\
\text { - Presidente da Previ entre } 1998 \text { e } 2002 \text {. } \\
\text { - Diretor de Relações com Investidores da Tupy de } 2002 \text { a } 2013 \text { (empresa de } \\
\text { fundições na qual a Previ tem participação de } 27,99 \%^{371} \text { na estrutura acionária } \\
\text { da entidade, enquanto o BNDESPar participa com outros 28,2\%). } \\
\text { - Diretor Presidente da Tupy desde } 2002 \text {. }\end{array}$ \\
\hline Carlos Eduardo Esteves Lima (2002) \\
\hline $\begin{array}{l}\text { - Formado em engenharia. } \\
\text { - Secretário-adjunto de Previdência Complementar (governo FHC). } \\
\text { - Nomeado pelo presidente da república interventor na Previ no ano de 2002, em } \\
\text { meio a disputas com sindicalistas. }\end{array}$ \\
\hline
\end{tabular}

\footnotetext{
${ }^{371}$ Segundo informações da empresa, a participação da Previ é de 28,2\%, segundo a Previ, no dado que expusemos anteriormente, a participação é de $27,99 \%$.
} 
- Subchefe-adjunto da Casa Civil (governo Lula).

- Ministro interino da Casa Civil (governo Lula).

Sergio Rosa (2003-2010)

- Bancário, funcionário do Banco do Brasil.

- Sindicalista, dirigente do Sindicato dos Bancários de São Paulo e presidente da Confederação Nacional dos Bancários.

- Formado em jornalismo.

- Diretor de Participações da Previ a partir de 1999.

- Vereador em São Paulo pelo PT.

- Indicado para a Previ por Luiz Gushiken, Antonio Palloci e Ricardo Berzoini, todos ministros do primeiro governo Lula. Gushiken e Berzoini foram, ainda, dirigentes do Sindicato dos Bancários de São Paulo.

- Entre 2010 e 2012, foi presidente da BrasilPrev, empresa que administra a previdência complementar aberta do Banco do Brasil.

- Atualmente, é vice-presidente do Conselho de Administração da BRF, por indicação da Previ.

\section{Ricardo Flores (2010-2012)}

- Bancário, funcionário de carreira do Banco do Brasil (entrou no banco como menor aprendiz).

- Formado em economia.

- Vice-presidente de crédito do BB durante o governo Lula.

- Visto como alguém com perfil "técnico".

- Saída teria sido motivada por divergências com o presidente do BB. Flores era nome ligado ao PT e ao PMDB.

- Presidente da Brasilprev por curto período (2012-2013).

\section{Dan Conrado (2012-2014 $\left.{ }^{372}\right)$}

- Bancário, funcionário de carreira do Banco do Brasil (entrou no banco como menor aprendiz).

- Formado em direito.

- No Banco do Brasil, foi administrador de agência, superintendente regional, superintendente, diretor de Marketing e Comunicação e vice-presidente de Varejo, Distribuição e Operações.

Elaboração própria. Fontes: diversas.

\begin{tabular}{|c|}
\hline Quadro 2 - Presidentes da Petros \\
\hline Carlos Henrique Flory (1999-2003) \\
\hline $\begin{array}{l}\text { - Formação em economia, com pós-graduação em finanças pela USP. } \\
\text { - Diretor-financeiro da Siemens } \\
\text { - Instituto de Previdência Municipal de São Paulo (Iprem) entre } 2005 \text { e } 2007 \\
\text { (gestões PSDB e PFL/DEM). }\end{array}$ \\
\hline
\end{tabular}

372 Dan Conrado anunciou em 28.11.2014 a sua saída da Previ devido a "mudanças no cenário político". Disponível em: <http://www.previ.com.br/menu-auxiliar/noticias-e-publicacoes/noticias/detalhes-danoticia/dan-conrado-comunica-aposentadoria.htm>. Acesso em: 30.11.2014. 
- Instituto de Previdência do Estado de São Paulo (gestão PSDB).

- Presidente da Fundação de Previdência Complementar do Estado de São Paulo (SP-PREVCOM) (gestão PSDB).

\section{Wagner Pinheiro (2003-2010)}

- Formado em economia.

- Analista de investimentos do Banespa, entre 1987 a 1991.

- Sindicalista, foi diretor da Federação dos Bancários da CUT/SP e da Associação dos Funcionários do Banespa, entre 1996 e 2002.

- Ligado ao PT de Campinas.

- Atual presidente dos correios.

\section{Luís Carlos Afonso (2011-2014)}

- Formado em economia.

- Consultor financeiro da FGV.

- Diretor administrativo da Assembleia Legislativa de São Paulo.

- Secretário de Finanças e Desenvolvimento da Prefeitura de São Paulo (gestão do PT).

- Diretor Financeiro e de Investimentos da Petros.

\section{Carlos Fernando Costa (2014-)}

- Formado em matemática.

- Carreira na Petros: Gerente Executivo de Planejamento de Investimentos, Gerente Executivo de Operações de Mercado, Diretor Financeiro e de Investimentos.

- Secretário Adjunto de Finanças da Cidade de São Paulo (gestão do PT).

- Diretor de Receita da Prefeitura Municipal de Santo André (gestão do PT).

- Secretário Adjunto de Finanças em Campinas (gestão do PT).

Elaboração própria. Fontes: diversas.

\begin{tabular}{|c|c|}
\hline \multicolumn{1}{|c|}{ Quadro 3 - Presidentes da Funcef } \\
\hline Edo Antônio Ferreira de Freitas (1999-2002) \\
\hline • & $\begin{array}{l}\text { Diretor da Companhia de Desenvolvimento Habitacional do Distrito Federal } \\
\text { (gestão DEM) }\end{array}$ \\
\hline Guilherme Lacerda (2003-2011) \\
\hline - & Doutor em economia. \\
- & Coordenador do curso de Economia da UFJF. \\
- & Consultor do Ministério da Educação. \\
- Assessor Econômico na Câmara dos Deputados (1991). \\
- Secretário Adjunto da Secretaria da Indústria e Comércio de Belo Horizonte \\
- (gestão do PT). \\
- do Estado do Espírito Santo (gestão do PT) \\
- Secretário de Planejamento do Estado do ES (gestão do PT) \\
\hline
\end{tabular}


pelo PT).

- Atualmente é Diretor de Infraestrutura Social, Meio Ambiente, e Agropecuária e Inclusão Social do BNDES.

Carlos Alberto Caser (2011-)

- Formado em Direito e História.

- Funcionário da Caixa desde 1982.

- Dirigente da Associação do Pessoal da Caixa Econômica Federal (APCEF) e da Federação Nacional das Associações do Pessoal da Caixa Econômica Federal (FENAE).

- Participou do Conselho de Administração da Funcef em 1993.

- Diretor de Controladoria da FUNCEF entre 2002 e 2007.

- Diretor de Benefícios entre 2007 e 2010.

- Presidente desde 2011.

Elaboração própria. Fontes: diversas.

Podemos concluir pelas informações expostas acima que os dirigentes dos fundos de pensão das estatais têm formações acadêmicas diversas e ocupam ou ocuparam cargos públicos de médio e alto escalão em governos das respectivas coalizões partidárias, lideradas, respectivamente, pelo PSDB e pelo PT. Isso demonstra que, como é próprio a qualquer posto de grande importância estratégica cuja indicação é dada por agentes políticos, a direção dos fundos é objeto de cobiça e disputa por estes agentes. Destacamos, a título exemplificativo, a intervenção feita pelo governo FHC na Previ em $2002^{373}$ e as mudanças realizadas no comando desta mesma entidade durante o governo Dilma por conta de divergências no Banco do Brasil ${ }^{374}$. Frisamos que, o fato de ser uma indicação política, em nossa opinião, não é absolutamente um demérito e não vai de encontro aos interesses dos participantes e assistidos pelos fundos. Dirigentes podem realizar boas ou más gestões de recursos, independente de serem ou não indicados por agentes políticos. Não haveria, ainda em nossa opinião, incompatibilidade entre eventual alinhamento de estratégias de investimento com as políticas de um determinado governo e a sustentabilidade financeira das entidades.

\footnotetext{
${ }^{373}$ O motivo alegado para a intervenção governamental foi a recusa da Previ em adaptar o seu estatuto às regras da Lei Complementar 108/2001, especialmente no que diz respeito ao voto de minerva do presidente do Conselho de Administração. Ver FOLHA DE SÃO PAULO. Governo intervém no fundo de pensão do BB. Disponível em: <http://www1.folha.uol.com.br/fsp/dinheiro/fi0406200212.htm>. Acesso em: 30.11.2014.

${ }^{374}$ Foi noticiado na imprensa que, após disputas entre o presidente do Banco do Brasil e o presidente da Previ, a presidenta Dilma optou pelo afastamento de Ricardo Flores. Ver O ESTADO DE SÃO PAULO. Ricardo Flores renuncia à presidência da Previ; Dan Conrado assume. Disponível em: $<$ http://economia.estadao.com.br/noticias/geral,ricardo-flores-renuncia-a-presidencia-da-previ-danconrado-assume,113859e >. Acesso em: 30.11.2014.
} 
Também a partir das informações acima, observamos ser comum que os dirigentes tenham um passado de funcionários nas empresas patrocinadoras dos fundos de pensão, e, no caso dos presidentes indicados durante os governos Lula e Dilma, estes dirigentes têm, ainda, destacada atuação sindical. Maria Jardim ${ }^{375}$ realizou estudo minucioso sobre a participação dos sindicatos na gestão dos fundos de pensão, demonstrando que há uma continuidade histórica entre as associações mutualistas do começo do século e os fundos de pensão atuais. Jardim descreve ainda a aproximação da elite sindical brasileira (especialmente bancária) dos postos de direção das entidades, movimento que atinge o seu auge com a vitória eleitoral do Partido dos Trabalhadores e que fica patente pelo currículo dos dirigentes.

Em suas textos e manifestações públicas, os presidentes das EFPCs enfatizam que o objetivo e o compromisso dos fundos de pensão são garantir rendimentos dos ativos para o pagamento de benefícios aos participantes, apesar de reconhecer o potencial das entidades na geração de poupança e no investimento. Vejamos:

O papel dos fundos de pensão sempre será o de garantir a aposentadoria de seus associados. No caso da Previ, mais de R 6 bilhões por ano. É um grande compromisso e este sempre será o nosso foco. Mas somos obviamente observados como poupança interna e como grandes investidores institucionais. Com desafios crescentes de rentabilidade, vamos buscar os melhores investimentos, em sintonia com os interesses do país. ${ }^{376}$

As pessoas pensam na PREVI como um grande investidor institucional. A entidade é lembrada pela grande contribuição para a economia e o desenvolvimento do país, mas o nosso principal objetivo, o que realmente nós somos é um gerador de tranquilidade. Cuidamos de quase 200 mil participantes e seus familiares, cerca de um milhão de pessoas. ${ }^{377}$

\footnotetext{
${ }^{375}$ JARDIM, Maria A. Chaves. Entre a solidariedade e o risco: sindicatos e fundos de pensão em tempos de governo Lula. São Paulo: Annablume, Fapesp, 2009, pp. 197-222.

376 Disponível em: <http://revistaepoca.globo.com/Revista/Epoca/0,EMI144722-15223,00RICARDO+FLORES+INVESTIMENTO+EM+INFRAESTRUTURA+E+ALTERNATIVA+PARA+PR EVI.html >. Acesso em: 30.11.2014.

377 Disponível em: <http://www.previ.com.br/previ-mobile/noticias/previ-realiza-seminario-sobre-ofuturo-da-previdencia-complementar-fechada.htm $>$. Acesso em: 30.11.2014.
} 
Os presidentes das EFPCs divergem quanto ao sentido de apoios políticos para as indicações à liderança dos fundos. Wagner Pinheiro, por exemplo, trata o assunto com naturalidade $^{378}$, enquanto Ricardo Flores afirma que o motivo da sua indicação teria sido o bom desempenho em cargos anteriores, todavia afirma ser natural a influencia do presidente da república. ${ }^{379}$ Sobre a influência estatal nas decisões dos fundos, Sergio Rosa fala em relação de parceria:

O nível de autonomia é muito grande. Obviamente, estamos sempre atentos a interpretar as políticas de governo, uma vez que elas influenciam o ambiente econômico. Fazemos isso como qualquer investidor. Temos tido um diálogo muito constante com o governo. Até em coisas que não andaram muito, como as parcerias públicoprivadas. $^{380}$

Quanto à ainda alta participação dos títulos da dívida pública na carteira dos fundos, os dirigentes reconhecem que isso se deve à alta rentabilidade que estes ativos sempre propiciaram, presidentes das três entidades afirmam estar concentrando sua carteira de títulos em papéis de longo prazo:

Em parte, por causa da memória de rentabilidade alta da renda fixa, que não desaparece de uma hora para outra. Ainda ontem, havia títulos do Tesouro de longo prazo pagando juros de $13 \%$ ao ano. (...) ainda é uma zona de conforto muito grande. Falta também um pouco de incentivo para buscar essa rentabilidade adicional em nome do participante do fundo. ${ }^{381}$

Aumentamos muito nossa participação em títulos públicos de longo prazo nos últimos três anos, como nos (papéis com vencimento em)

\footnotetext{
378 Disponível em: <http://www.valor.com.br/arquivo/473965/presidente-da-petros-diz-que-foi-indicadopor-gushiken>. Acesso em: 30.11.2014.

379 Disponível em: <http://revistaepoca.globo.com/Revista/Epoca/0,,EMI144722-15223,00RICARDO+FLORES+INVESTIMENTO+EM+INFRAESTRUTURA+E+ALTERNATIVA+PARA+PR EVI.html http://www1.folha.uol.com.br/fsp/mercado/me0507201021.htm>. Acesso em: 30.11.2014. 380 Disponível em: <http://www.contec.org.br/index.php/contec-online/informes-anteriores-geral/102outubro-2009/2248-2248 >. Acesso em: 30.11.2014. É necessário lembrar, entretanto, que há um forte questionamento quanto à existência e à conveniência da influencia estatal nas decisões dos fundos de pensão. Recentemente, chapas portando este discurso elegeram representantes para os Conselhos Deliberativos das EFPCs, derrotando as chapas ligadas aos sindicalistas. Ver: <http://www.istoe.com.br/reportagens/paginar/367202_COMO+O+PT+PERDEU+PODER+NOS+FUND OS+DE+PENSAO/2>. Acesso em: 30.11.2014.

381 Disponível em: <http://www.contec.org.br/index.php/contec-online/informes-anteriores-geral/102outubro-2009/2248-2248>. Acesso em: 30.11.2014.
} 
2039, 2040, 2045. Fomos grandes compradores de títulos, mas agora nem tanto, porque as taxas já não estão tão atrativas. ${ }^{382}$

Percebe-se, ainda, através da leitura do conjunto das manifestações dos dirigentes, que a lógica de mercado está presente de maneira muito forte nas decisões sobre alocação dos recursos dos fundos de pensão, seja em relação à valorização do mercado imobiliário, ao crescimento do comércio varejista com a ampliação do consumo das famílias, ou à infraestrutura. Apesar de não terem a sua origem no mundo dos negócios, ao contrário, boa parte veio do movimento sindical, podemos notar que estes dirigentes estão sujeitos a estes constrangimentos, especialmente por conta dos ditames de rentabilidade e liquidez dos fundos. O fato de que os dirigentes das EFPCs, independente de sua origem, seguirem a lógica própria de atuação dos fundos pode indicar que não é tão relevante eventuais diferenças entre perfis de direção.

Por outro lado, vejamos os discursos que se referem aos investimentos em infraestrutura:

(...) há essa possibilidade de agirmos de maneira integrada com a sociedade e a necessidade que o Brasil possui de infra-estrutura. $\mathrm{O}$ Brasil precisa demais de investimentos nessa área e, se os fundos de pensão puderem participar, estarão contribuindo de maneira mais ampla, ajudando a arrumar emprego e também valorizando nossos artigos [sic] (...) um outro aspecto importantíssimo nessas parcerias é que o fundo e seus parceiros (como o financiador BNDES, por exemplo) estabeleçam um manual de governança no contrato do projeto para que tenham participação na definição de como será a gestão. $^{383}$

Com a tendência de crescimento da poupança institucional corporativa de longo prazo e com a perspectiva de redução do custo da dívida pública em relação ao Produto Interno Bruto (PIB), haverá uma maior

\footnotetext{
${ }^{382}$ Disponível em: < http://noticias.uol.com.br/ultnot/2007/06/06/ult29u55820.jhtm > Disponível em: < http://www.contec.org.br/index.php/contec-online/informes-anteriores-geral/102-outubro-2009/2248$\underline{2248}$ >. Acesso em: 30.11.2014. Declarações semelhantes de Wagner Pinheiro (Petros) e Dan Conrado (Previ) deram declarações no mesmo sentido. Ver: <http://www.fetecpr.org.br/presidente-da-petrosreitera-oportunidade-para-os-fundos-de-pensao/> <http://noticias.uol.com.br/ultnot/2007/06/06/ult29u55820.jhtm>. Acesso em: 30.11.2014. 383 Disponível <http://www.istoe.com.br/assuntos/entrevista/detalhe/15196_DINHEIRO+PARA+O+SOCIAL+>. em:
} Acesso em: 30.11.2014. 
disponibilidade de recursos dos investidores institucionais para serem destinados a investimentos alternativos, que não o passivo nacional do qual somos o maior financiador. (...) As taxas de juros reais projetadas para o futuro exigem que busquemos alternativas de investimentos compatíveis com as nossas obrigações. Por isso, a Funcef, juntamente com outras fundações, criou fundos de investimento nas áreas de infra-estrutura, de aquisição, participação e gestão de empresas de setores específicos. ${ }^{384}$

Vamos continuar investindo fortemente porque as carências estão aí e nós precisamos de rentabilidade. São projetos de longo prazo e que casam perfeitamente com o nosso perfil. ${ }^{385}$

Nestas últimas falas percebemos que, se por um lado é verdade que os presidentes dos fundos veem oportunidades de valorização dos ativos, por outro lado eles trazem em seus discursos a ideia de "colaboração" com outros setores da sociedade e o poder público. Entretanto, entendemos que seria precipitada uma conclusão definitiva neste sentido.

\subsection{Conclusões parciais}

Nos dados e casos expostos, comprovamos a hipótese que, de fato, os fundos de pensão são importantes provedores de funding para as principais empresas do país. Pudemos ver alguns exemplos de atuação do poder público atua como acionista minoritário com a participação societária em empresas, holdings, e Fundos de Participação, por meio BNDESPAR, do FI-FGTS e especialmente dos fundos de pensão. Essa participação minoritária é decisiva para viabilizar projetos na área de infraestrutura ou mesmo para influenciar nas decisões de comando nas companhias. Trata-se de assumir um papel não de "empresário", mas de "capitalista".

Os fundos de pensão (...) não logram realizar o papel do 'empresário' e sim do 'capitalista', pois a sua função é a de fornecer capitais a novos empreendimentos. Eles não sabem combinar os elementos existentes para a realização de inovações, mas dispõem de recursos

\footnotetext{
${ }^{384}$ Disponível em: 〈http://migre.me/ncG9I $>$. Acesso em: 30.11.2014.

385 Disponível em: <http://www.valor.com.br/financas/2936894/funcef-quer-mais-infraestrutura $>$. Acesso em: 30.11.2014.
} 
que precisam ser valorizados e necessitam do dinamismo inerente à capacidade empresarial. ${ }^{386}$

Para Fernando Nogueira da Costa, está em curso nesta etapa do desenvolvimento capitalista no Brasil um novo modelo de atuação do Estado na economia, com a substituição da participação como acionista majoritário e controlador de empresas por esta participação, e até controle, indireto, que ele chama de modelo de acionista minoritário. A participação do Estado como acionista minoritário gera funding para as empresas (caso da Sete Brasil, das concessões de infraestrutura da Invepar, da concessionária da UHE Belo Monte e da BRF Foods) e também atua na definição de estratégias (caso Vale):

Enfim, o argumento analítico é que alteraram-se a regulação e o direcionamento das grandes empresas brasileiras, sejam as estatais em que o Conselho de Administração que define as estratégias da empresa é presidido por membro do controlador (a União), sejam as privadas em que o Estado brasileiro trocou controle majoritário por minoritário. Ao adquirir ações de empresas estratégicas, via BNDESPAR e fundos de pensão patrocinados, o Estado visava elevar a competitividade brasileira. No modelo de acionista minoritário, o Estado possui grande influência em todo o Brasil corporativo, inclusive aumentando o retorno destas companhias sobre seus ativos, já que as participações estatais favorecem o provimento de recursos em longo prazo que não conseguem em mercado de capitais. ${ }^{387}$

Em nossa opinião, esta forma de atuação do Estado na economia vai ao encontro do novo momento do ciclo capitalista, no qual predomina a acumulação na esfera financeira, e das restrições fiscais que decorreram da crise da dívida e das mudanças no direito financeiro ${ }^{388}$. Também pode se constituir como uma alternativa frente ao processo de venda de ativos que aconteceu durante a década de 1990.

\footnotetext{
386 MATIJASCIC. Milko. Fundos de pensão e rearticulação da economia brasileira. Campinas: UNICAMP, 1994, p. 33.

387 COSTA, Fernando Nogueira da. Financiamento interno de longo prazo. In CALIXTRE, André Bojikian; BIANCARELLI, André Martins; CINTRA, Marcos Antonio Macedo. Presente e futuro do desenvolvimento brasileiro. IPEA. Brasília, 2014, p. 300.

${ }^{388}$ MASSONETTO, Luís Fernando. O Direito Financeiro no Capitalismo Contemporâneo: a emergência de um novo padrão normativo. Tese de doutorado apresentada ao Departamento de Direito Econômico, Financeiro e Tributário da Faculdade de Direito da USP. São Paulo, 2006.
} 
O Estado que antes fabricava aviões por meio da Embraer, hoje oferece funding para que estaleiros nacionais produzam, a partir de conteúdo local, sondas de exploração de petróleo em águas profundas. Igualmente, o Estado que criou a Vale do Rio Doce para fornecer insumos no seu processo de industrialização, hoje busca influenciar nas decisões da empresa com a participação das EFPCs em fundos de investimento acionistas da companhia. O mesmo exemplo vale para as concessões de ferrovias, rodovias e de energia elétrica, no qual através da Neoenergia permanece uma participação significativa estatal.

Trazendo essa ideia de atuação estatal via fundos de pensão para o campo do direito econômico, em especial a tipologia de Eros Grau vista no capítulo anterior, percebemos que esta forma de atuação estatal, que podemos chamar aqui de Estado investidor, enquadra-se como uma atuação no domínio econômico. Certamente, esta não é uma atuação por absorção (não há regime de monopólio), e mesmo a classificação como uma intervenção por participação não parece estar em perfeita conformidade com a realidade, pois não há empresas estatais propriamente ditas atuando no mercado em competição com privados. Há, sim, uma participação estatal, porém por meios indiretos. De alguma forma, trata-se também de uma intervenção por indução, na qual há um convite, isto é, um estímulo ao setor privado para atuar de acordo com as prioridades definidas pelo poder público; todavia não há a edição de normas ou regulamentos, que completaria a caracterização da intervenção sobre o domínio econômico por indução.

Esta forma de atuação dos fundos de pensão como "capitalistas" não escapa, entretanto, dos constrangimentos impostos pela lógica de mercado. As entidades não podem simplesmente dispor de - todos - os seus recursos seguindo eventuais estratégias de desenvolvimento ou provisão de fundos pra determinados setores da atividade econômica. Premidos pelas necessidades de liquidez, de proteção dos seus ativos, tendo em vista as expectativas de seus participantes e o atingimento da meta atuarial, os fundos de pensão seguem as tendências de mercado, fazendo opções mais conservadoras ou mais arrojadas e alocando recursos de acordo com a conjuntura. Exemplos disso são a migração para ativos mais conservadores durante a crise de 2008, e a busca por alternativas aos títulos da dívida pública com o processo de redução de juros em 2012. 


\section{CONSIDERAÇÕES FINAIS}

Buscamos investigar, ao longo deste trabalho, as mudanças na economia mundial e brasileira nas últimas décadas do século $\mathrm{XX}$, a regulação das Entidades Fechadas de Previdência Complementar no país e a maneira como a interação entre tais mudanças econômicas e a forma jurídica da regulação possibilitaram ao Poder executivo brasileiro ter considerável influência sobre os três maiores fundos de pensão do país. Analisamos também o perfil dos investimentos realizados por estes fundos, as empresas por eles participadas e a origem e declarações públicas de seus dirigentes.

Vimos neste trabalho que o chamado Welfare State Keynesiano (WSK) foi um arranjo de organização econômica que possibilitou a boa parte dos países capitalistas um período de estabilidade financeira e expansão da riqueza. O WSK esteve associado à etapa de acumulação realizada predominantemente na esfera produtiva, e teve como um de seus sustentáculos o fundo público e a atuação do Estado no provimento de bens e serviços e na ampliação da proteção social aos cidadãos. Corolários a esta forma de organização capitalista estiveram os sistemas públicos de previdência por repartição, nos quais Estado, empregadores e trabalhadores contribuíam para o pagamento de benefícios àqueles que não conseguiam vender a sua força de trabalho no mercado.

Todavia, este modelo perdeu sustentação a partir da década de 1970 quando começa a fase de acumulação predominantemente financeira do ciclo americano. As fases de acumulação financeira, para Arrighi, decorrem da tendência à queda na taxa de lucro, que faz aumentar o pessimismo dos grandes agentes capitalistas em relação ao retorno dos investimentos, o que os leva a deslocar seus fluxos de caixa para o sistema de crédito. Assim, observa-se nas últimas décadas do século XX uma expansão dos ativos financeiros por todo o mundo, especialmente com o crescimento da liquidez mundial e consequente queda do padrão dólar-ouro. Com a securitização do mercado de dívida pública e a crescente complexidade e inovação dos ativos financeiros, aprofunda-se um período de desregulamentação dos sistemas financeiros e maior mobilidade do capital.

Característica da expansão financeira importante para a compreensão do objeto estudado neste trabalho é a exterioridade dos proprietários em relação à esfera produtiva, o que se chamou de capitalismo patrimonial, no qual a propriedade se manifesta principalmente através de títulos das empresas. Neste contexto, ganham grande protagonismo os investidores institucionais, que atuam como centralizadores dos 
lucros não reinvestidos e rendas não consumidas, e tornam-se grandes detentores de ações das empresas e portadores de títulos de dívida pública e privada. Dentre os investidores institucionais, aparecem com destaque os fundos de pensão - instituições que arrecadam vultosos recursos com a poupança dos trabalhadores. Estes recursos são canalizados especialmente para ativos financeiros com o intuito de valorizá-los para o pagamento posterior de benefícios de previdência, num regime previdenciário por capitalização.

Arrecadando recursos de rendas não-consumidas dos trabalhadores, que de outro modo escapariam do sistema financeiro, os fundos de pensão passam a constituir um pilar importante da fase de acumulação na esfera financeira. Assim, a previdência por capitalização constitui-se o regime previdenciário característico da etapa atual do capitalismo, e passa a ser paulatinamente adotado em todo o mundo, inclusive com o incentivo de organismos internacionais.

No Brasil, a expansão financeira, especialmente após os choques do petróleo e o aumento dos juros, põe fim a um período de crescimento econômico calcado no endividamento externo, o que leva o Estado brasileiro a uma profunda crise fiscal que se manifesta, na década de 1980 com a moratória da dívida externa. Vimos que o setor público foi o mais afetado pela interrupção dos fluxos externos, por conta da assunção das dívidas do setor privado e pelo grande volume do passivo em moeda estrangeira das estatais. Estas viram a sua capacidade de investimento ser reduzida substancialmente, ao passo que cresciam as suas despesas financeiras com a elevação dos juros e também pela política cambial adotada. Com isso, o Estado brasileiro perde capacidade de atuação e direção econômica.

Ao analisarmos o arcabouço normativo que conforma a seguridade social no país, vimos que a Constituição de 1988 estabeleceu dois núcleos de previdência: o primeiro, o núcleo básico, é formado pela previdência pública financiada de forma tripartite pelo setor público, trabalhadores e empregadores. Trata-se de um modelo de repartição de cobertura universal e filiação compulsória, no qual está presente a ideia da solidariedade, inclusive entre as gerações. Isso porque, apesar de ter um caráter contributivo (os seus benefícios estão ligados ao período e ao montante das suas contribuições), a previdência social também estabelece regras específicas para a proteção de grupos vulneráveis. Este sistema está em consonância com o modelo de 
previdência do Estado de Bem Estar Social, com forte participação pública no seu financiamento.

O segundo núcleo da previdência brasileira é o núcleo complementar, ou privado. A previdência privada tem antecedentes históricos no Brasil que remontam ao século XIX, com as instituições de caráter mutualista dos trabalhadores. Em 1977, a previdência privada passa a ter uma regulação que a organiza juridicamente e institucionaliza as suas atribuiçõoes sob supervisão estatal. Com a Constituição de 1988, este núcleo passa a ser previsto entre as instituições do sistema financeiro, mas apenas na reforma de 1998 ganha tratamento mais detido e sistemático. A EC 20/1998 organizou a previdência privada de forma autônoma à previdência social, estabelecendo o seu caráter de complementariedade e facultatividade.

Nos anos de 1998 e 2003 foram operadas reformas na arquitetura constitucional da previdência, que, em suma, tornaram mais rígidos os critérios para acessar os benefícios do regime público, consonância com a tendência mundial. Estas reformas foram justificadas pelo envelhecimento populacional e pela consequente necessidade de aportes estatais cada vez maiores. Além disso, tiveram um objetivo econômico explícito, qual seja, incentivar a formação de poupança interna e o nível de investimento do país com a expansão da previdência privada.

Concluímos que o Brasil mantém um sistema previdenciário híbrido, cabendo ao núcleo básico um papel relevante na cobertura universal dos riscos sociais, principalmente das camadas menos abastadas e grupos sociais em situação de vulnerabilidade, até determinado limite (hoje em torno de 4,4 mil reais), a partir do qual entram em cena o núcleo de previdência complementar. Pelas suas características, o núcleo básico de previdência está inserido no âmbito dos serviços públicos, enquanto o núcleo complementar pode ser classificado como atividade econômica em sentido estrito, sendo objeto de regulação, supervisão e fiscalização estatal por parte dos órgãos desenhados para estas funções (CNPC, PREVIC, CMN, dentre outros).

As Leis Complementares 108/2001 e 109/2001 dão forma às entidades de previdência complementar, regulamentando o seu funcionamento, seu estatuto jurídico, planos de benefícios e governança. Vimos que estas Leis se preocupam com a proteção da higidez dos investimentos e com a profissionalização da gestão destas entidades. Trata-se de 
uma regulação prudencial, que determina a realização de auditorias, prestações de contas, reservas técnicas, dentre outros mecanismos.

A LC 108/2001, em particular, se preocupa com a organização interna e governança das Entidades Fechadas de Previdência Complementar que são patrocinadas por órgãos e entidades do poder público. Aprovada com o apoio de dirigentes sindicais, a legislação estabelece presença paritária de representantes dos patrocinadores e participantes/assistidos nos órgãos de cúpula destas entidades, contudo dá o voto de qualidade (desempate) ao presidente, indicado pela patrocinadora (órgão ou entidade pública).

Pudemos observar que, ao disciplinar os investimentos das Entidades Fechadas de Previdência Complementar, o Conselho Monetário Nacional não estabelece limites mínimos ou compulsórios de investimento, e dá grande discricionariedade aos administradores dos fundos de pensão para a aplicação dos seus investimentos. Assim, ao tempo em que reafirmou a necessidade de proteção patrimonial das entidades e seus participantes e patrocinadores, conferiu um importante poder decisório aos gestores e dirigentes das EFPCs.

Os elementos expostos acima conferem aos fundos de pensão patrocinados pelas estatais brasileiras (em especial Previ, Petros e Funcef, estudados neste trabalho) um grande protagonismo na economia nacional. Por meio destes fundos, e em associação com outros fundos e bancos públicos, o Estado brasileiro exerce o que se chamou de poder acionário no domínio econômico, valendo-se de participações em ações de empresas e outros fundos de investimento para provisão de funding e estímulos a determinados setores econômicos.

Este poder de acionista minoritário é demonstrado na presença forte dos fundos de pensão das estatais como empreendedores nas áreas de infraestrutura e logística, nas quais o financiamento oriundo do setor privado, por si só, poderia não dar conta de promover os investimentos necessários. Os fundos ajudam a articular e estruturar estes setores, em consonância com a forma de atuação do Estado preconizada por Mariana Mazzucato. Exemplos são as concessões de hidrelétricas, ferrovias, rodovias e aeroportos com participação destes fundos de pensão nos consórcios, bem como no fundo de investimento em participações que pretende viabilizar as sondas para exploração e produção de petróleo em águas ultra profundas (camada pré-sal). Os 
fundos também exercem papel fundamental mantendo o controle indireto do Estado sobre a maior empresa mineradora do país, a Vale, e suas subsidiárias de logística.

Quando observamos a distribuição da carteira de ativos dos fundos das estatais, bem como o extenso e diverso rol de empresas participadas, podemos notar que estas EFPCs possuem um comportamento diferenciado. De fato, a maioria dos fundos de pensão privados possuem carteiras muito conservadoras, concentradas em títulos da dívida pública, o que lhes confere segurança e rendimentos relativamente elevados para honrar os compromissos que lhe são típicos. Já estes três fundos das estatais possuem participação muito maior de ações, fundos de investimentos em ações e investimentos estruturados em suas carteiras. Isto se deve em parte ao seu tamanho, como vimos, mas não só, pois as maiores EFPCs privadas também estão concentradas na renda fixa.

Entretanto, a capacidade discricionária de atuação sofre sérios constrangimentos provenientes da necessidade de rendimento e liquidez das EFPCs. Percebemos que, para manter o seu equilíbrio atuarial e consequentemente sua capacidade de pagar benefícios aos participantes e assistidos, os fundos seguem os movimentos de mercado, modificando a composição de suas carteiras de investimentos de acordo com alta ou baixa de juros e o comportamento da bolsa. Esta tensão está expressa nas declarações públicas de seus dirigentes, que, mesmo com origens diversas dos operadores financeiros tradicionais, reiteram compromissos com a rentabilidade e segurança do fundo.

Em suma, esta dissertação mostrou que há atuação do Estado no domínio econômico via fundos de pensão, sem a pretensão de oferecer respostas definitivas a esta problemática. Vimos de uma maneira ampla que os fundos compõem uma nova forma de atuação estatal, característica da atual etapa de expansão financeira do capitalismo, que utiliza os instrumentos e inovações do mercado financeiro em articulação com outros investidores públicos e privados.

O aprofundamento da pesquisa sobre os fundos de pensão é importante, pela relevância que estas entidades têm na atualidade, e pode ser muito fecunda quando combinados os instrumentais oferecidos pelo direito econômico, pela sociologia econômica e pela economia política. Há uma vasta agenda de pesquisa, cujos elementos foram tangenciados por esta dissertação e que precisam de uma análise mais detida. Neste 
sentido, apontamos cinco linhas de investigação para aprofundar a pesquisa realizada neste trabalho.

A primeira delas é a verificar se há realmente uma estratégia de desenvolvimento que conduz os investimentos dos fundos de pensão das estatais, se esta eventual estratégia está alinhada aos instrumentos de planejamento governamental, como os planos plurianuais (PPA), o Programa de Aceleração do Crescimento (PAC) e as políticas setoriais, bem como os seus resultados. Afinal, vimos neste trabalho que há grande quantidade de funding arrecadado e disponibilizado para empresas, entretanto não fica claro se há uma lógica nesta atuação e para onde ela aponta.

A segunda linha de pesquisa diz respeito à lógica decisória adotada para os investimentos do fundo de pensão, por meio do exame das suas justificativas e posicionamento dos seus dirigentes em atas das reuniões dos Conselhos Deliberativos e Diretorias-Executivas, tendo em vista, inclusive, os responsáveis pelas indicações destes dirigentes (patrocinadora ou participantes).

Uma terceira linha refere-se à participação dos fundos de pensão das estatais nas iniciativas de ciência, tecnologia e inovação. Os dados expostos neste trabalho indicam que é robusta a presença dos fundos nos setores regulados e de infraestrutura, entretanto mostram uma participação ainda incipiente em Fundos de Investimento em Empresas Emergentes (FMIEE). Estudar o papel das EFPCs neste quesito é premente, já que o estímulo à inovação é essencial para a promoção do desenvolvimento na sociedade do conhecimento.

Outra linha de pesquisa sugerida é o comportamento que as empresas participadas assumem em relação às questões trabalhistas e de sustentabilidade social e ambiental. Afinal, como vimos neste trabalho, os fundos de pensão são constituídos por uma massa de recursos arrecadados dos trabalhadores, e estes tem participação importante na sua direção. Entretanto, vimos que a expansão financeira têm aumentado os ditames de rentabilidade e que há algumas denúncias de desrespeito à legislação trabalhista e de promoção de impactos sociais e ambientais negativos em empreendimentos participados pelos fundos, especialmente na área de infraestrutura. Daí a importância de verificar com mais profundidade se e de que forma os próprios trabalhadores, por meio dos seus gestores nas EFPCs, podem estar contribuindo para a superexploração do trabalho e para a geração destes impactos. 
Por último, pode-se aprofundar a relação entre os fundos de pensão das estatais e o planejamento, o uso e a ocupação do solo urbano. De fato, estes fundos são responsáveis por quantidade significativa de aporte de recursos em operações urbanas e empreendimentos imobiliários, especialmente com o desenvolvimento de inovações financeiras que tem esta finalidade específica, como o Certificado de Potencial Adicional de Construção (CEPAC).

Enfim, há uma gama de questões que demandam aprofundamento teórico e empírico. Este estudo procurou enfrentar algumas delas e indicar outras, mas ainda há um longo caminho de pesquisa a se trilhar. 


\section{REFERÊNCIAS BIBLIOGRÁFICAS}

ALENCAR, Marcele Caroline Maciel de. Defesa do contrato previdenciário das Entidades Fechadas de Previdência Complementar: aspectos jurídicos relevantes e proposições. In PREVIC. $2^{o}$ Prêmio PREVIC de Monografias: previdência complementar fechada. Brasília, 2010.

AMARAL, Felipe Vilhena Antunes. Desafios na gestão dos ativos financeiros $e$ passivos previdenciários nos fundos de pensão. In PREVIC. $3^{\circ}$ Prêmio PREVIC de Monografias: previdência complementar fechada. Brasília, 2011.

ARAGÃO, Alexandre Santos de. Direito dos Serviços Públicos. 2aed. Forense: Rio de Janeiro, 2008.

ARRIGHI, Giovanni. O Longo Século XX: Dinheiro, Poder e as Origens do Nosso Tempo. São Paulo: Unesp, 1996.

BELLUZZO, Luiz Gonzaga. Finança global e ciclos de expansão. In FIORI, José Luís. Estados, moedas e desenvolvimento. In FIORI, José Luís (org.). Estados e moedas no desenvolvimento das nações. $2^{\text {a }}$ Ed. Petrópolis: Editora Vozes, 1999.

BERCOVICI, Gilberto, O Ainda Indispensável Direito Econômico. In BENEVIDES, Maria Victoria de Mesquita; BERCOVICI, Gilberto \& MELO, Claudineu de (orgs.), Direitos Humanos, Democracia e República: Homenagem a Fábio Konder Comparato, São Paulo, Quartier Latin, 2009.

BERCOVICI, Gilberto. Constituição Econômica e Desenvolvimento: uma leitura a partir da constituição de 1988. Malheiros Editores. São Paulo, 2005.

BERCOVICI, Gilberto. O Ainda Indispensável Direito Econômico. In BENEVIDES, Maria Victoria de Mesquita; BERCOVICI, Gilberto; MELO, Claudineu de (orgs.), Direitos Humanos, Democracia e República: Homenagem a Fábio Konder Comparato. São Paulo: Quartier Latin, 2009.

BERCOVICI, Gilberto. Petróleo, Recursos Minerais e Apropriação do Excedente. Tese de titularidade apresentada à Faculdade de Direito da USP. São Paulo, 2010, pp. 234235; ver ainda, GRAU, Eros Roberto, A Ordem Econômica na Constituição de 1988 (Interpretação e Crítica), 12ªed., São Paulo, Malheiros, 2007.

BERZOINI, Ricardo. Previdência Social: a mudança com justiça e respeito. In: MORHY, Lauro (org.). Reforma da Previdência em questão. Editora UnB, 2003.

BLACKBURN, Robin. Banking on Death or investing in life: the history and future of pensions. Verso. Nova York, 2002.

BRENNER, Robert. O Boom e a bolha: os Estados Unidos na economia mundial. Rio de Janeiro: Record, 2003.

CALIXTRE, André Bojikian; BIANCARELLI, André Martins; CINTRA, Marcos Antonio Macedo. Presente e futuro do desenvolvimento brasileiro. IPEA. Brasília, 2014. 
CAMARA, Mamadou; SALAMA, Pierre. A inserção diferenciada - com efeitos paradoxais - dos países em desenvolvimento na mundialização financeira. In CHESNAIS, François (Org.). A finança mundializada. São Paulo: Boitempo, 2005.

CARNEIRO, Ricardo. Desenvolvimento em Crise: a economia brasileira no último quarto do século XX. Editora Unesp, IE Unicamp. São Paulo, 2002.

CECHIN, José; CECHIN, Andrei Domingues. Desequilíbrios: Causas e soluções. In GIAMBIAGI, Fábio; TAFNER, Paulo. (orgs.) Previdência no Brasil: debates dilemas e escolhas. IPEA, Rio de Janeiro, 2007.

CHESNAIS, François (Org.). A finança mundializada. São Paulo: Boitempo, 2005,.

CHESNAIS, François. (Org.). A mundialização financeira: gênese, custos e riscos. São Paulo: Xamã, 1998.

CHESNAIS, François. El fin de um ciclo: Alcance y rumbo de la crisis financeira. 2008. Disponível em: <http://www.iade.org.ar/uploads/c87bbfe5-1033-09ca.pdf >. Acesso em: 31.07.2012.

COMPARATO, Fábio Konder. "Ordem Econômica na Constituição Brasileira de 1988”, Revista de Direito Público n 93, São Paulo, RT, janeiro/março de 1990.

COMPARATO, Fábio Konder. O Indispensável Direito Econômico. In Estudos e Pareceres de Direito Empresarial. Rio de Janeiro: Forense, 1978.

CORREAA, Vanessa Petrelli; ALMEIDA FILHO, Niemeyer. Fragilidade financeira e vulnerabilidade externa em países periféricos. In CASSIOLATO, José Eduardo; MATOS, Marcelo Pessoa de; LASTRES, Helena M. M. Desenvolvimento $e$ mundialização - O Brasil e o pensamento de François Chesnais. E-papers: Rio de Janeiro, 2014.

CORREIA, Marcus Orione Gonçalves; CORREIA, Érica Paula Barcha. Curso de direito da seguridade social. São Paulo, Saraiva, 2002.

COSTA, Fernando Nogueira da. Financiamento interno de longo prazo. In CALIXTRE, André Bojikian; BIANCARELLI, André Martins; CINTRA, Marcos Antonio Macedo. Presente e futuro do desenvolvimento brasileiro. IPEA. Brasília, 2014.

COSTA, Fernando Nogueira da. I Relatório de Pesquisa para o IPEA. PND 059-2012. 2012.

COUTINHO, Carlos Nelson. Contra a corrente: ensaios sobre democracia $e$ socialismo. São Paulo: Cortez Editora, 2000.

COUTINHO, Luciano. $O$ desenho de um novo modelo de financiamento para a América Latina. In: COUTINHO (Org.). Fundos de Pensão: novo fator de desenvolvimento para a América Latina. IE/UNICAMP. Campinas, 1996. 
CRUZ, Paulo R. Davidoff C. Notas sobre financiamento de longo prazo na economia brasileira do após guerra, 12/1994, Economia e Sociedade (UNICAMP. Impresso), Vol. S/N, Fac. 3, Campinas, 1994.

DUARTE, Anna Luiza. A gestão dos fundos de pensão e a sua influencia sobre a organização interna das empresas participadas. Dissertação de Mestrado apresentada à Faculdade de Direito da Universidade de São Paulo, 2003.

EVANS, Peter. A tríplice aliança: as multinacionais, as estatais e o capital nacional no desenvolvimento dependente brasileiro. Rio de Janeiro: Zahar, 1980.

FIORI, José Luís. Estados, moedas e desenvolvimento. In FIORI, José Luís (org.). Estados e moedas no desenvolvimento das nações. $2^{\text {a }}$ Ed. Petrópolis: Editora Vozes, 1999.

FIORI, José Luís. O nó cego do desenvolvimentismo brasileiro. In Novos Estudos CEBRAP n ${ }^{\circ}$ 40, novembro de 1994.

FIORI, José Luís. $O$ vôo da coruja: para reler o desenvolvimentismo brasileiro. Ed. Record. Rio de Janeiro, 2003.

FIORI, José Luís. Para repensar o papel do Estado sem ser um neoliberal. In Revista de Economia Política, vol. 12, no 1, janeiro/março de 1992, pp. 76-89.

FRANÇA, Álvaro Sólon. A Previdência Social e a Economia dos Municípios. Brasília, ANFIP, 1999.

FURTADO, Celso. Formação Econômica do Brasil. Edição comemorativa: 50 anos. Companhia das Letras. São Paulo: 2009, pp.

GIAMBIAGI, Fábio; OLIVEIRA, Francisco Eduardo Barreto de; BELTRÃO, Kaizô Iwakami. Alternativas de Reforma da Previdência Social. Revista do BNDES nº 6, dezembro de 1996.

GIAMBIAGI, Fábio; TAFNER, Paulo. (orgs.) Previdência no Brasil: debates dilemas e escolhas. IPEA, Rio de Janeiro, 2007.

GRANEMANN, Sara. Políticas Sociais e Financeirização dos Direitos do Trabalho. In Revista da Faculdade de Serviço Social da Universidade do Estado do Rio de Janeiro, $\mathrm{n}^{\circ}$ 20, 2007.

GRAU, Eros Roberto, A Ordem Econômica na Constituição de 1988 (Interpretação e Crítica), 12ªed., São Paulo: Malheiros, 2007.

GRAU, Eros Roberto. Constituição e Serviço Público. In GRAU, Eros Roberto e GUERRA FILHO, Willis Santiago (orgs). Direito Constitucional: estudos em homenagem a Paulo Bonavides. Malheiros: São Paulo, 2003.

GREMAUD, Amaury Patrick; VASCONCELOS, Marco Antonio Sandoval; TONETO JUNIOR, Rudinei. Economia Brasileira contemporânea. $7^{\mathrm{a}}$ edição. $11^{\mathrm{a}}$ reimpressão. Editora Atlas. São Paulo, 2014. 
GUERZONI, Ana Paula et al. Comentários à Lei Complementar n. 109/01. In CORREIA, Marcus Orione Gonçalves; VILLELA, José Corrêa. (coord. e org.). Previdência Privada: Doutrina e comentários à Lei Complementar n. 109/01. LTr, São Paulo, 2005.

GUIMARÃES, Magda Cristiane Monteiro. Estudo do programa de educação financeira nas Entidades Fechadas de Previdência Complementar. In MINISTÉRIO DA PREVIDÊNCIA SOCIAL. 2 ${ }^{\circ}$ Prêmio PREVIC de Monografias: previdência complementar fechada. Brasília, 2010.

IBRAHIM, Fábio Zambitte. Curso de direito previdenciário. 15. ed., rev., amp. e atual. Niterói, RJ: Impetus, 2010.

INSTITUTO DE PESQUISA ECONÔMICA APLICADA. Estado, instituições $e$ democracia: desenvolvimento. Livro 9, Volume 3. Ipea, Brasília, 2010.

INSTITUTO DE PESQUISA ECONÔMICA APLICADA. Macroeconomia para o Desenvolvimento: crescimento, estabilidade e emprego. Livro 4. Ipea, Rio de Janeiro, 2010.

JARDIM, Maria A. Chaves. Entre a solidariedade e o risco: sindicatos e fundos de pensão em tempos de governo Lula. São Paulo: Annablume, Fapesp, 2009.

JARDIM, Maria A. Chaves. Fundos de Pensão: o investimento dos fundos de pensão durante o governo Lula, a construção das crenças de responsabilidade social $e$ sustentabilidade e o recente interesse por investimentos na Amazônia brasileira. Relatório de pesquisa apresentado ao Inesc. 2010.

KEYNES, John Maynard. $O$ fim do Laissez-Faire. 1926. Disponível em: $<$ http://www.cefetsp.br/edu/eso/globalizacao/fimlaissezfaire.html $>$. Acesso em: 14.12.2014.

KEYNES, John Maynard. Teoria Geral do Emprego, do Juro e da Moeda. Lisboa: Relógio D’Água Editores, 2010.

LUÍS, Alessandro S. Octaviani, Recursos Genéticos e Desenvolvimento: Os Desafios Furtadiano e Gramsciano, mimeo, São Paulo, Tese de Doutoramento (Faculdade de Direito da USP), 2008.

MARQUES NETO, Floriano de Azevedo. A nova regulação dos serviços públicos. In Revista de Direito Administrativo v.228. Renovar: Rio de Janeiro, 2002.

MARTINEZ, Wladmir Novaes. Curso de Direito Previdenciário. Tomo II: Previdência Social. São Paulo, LTr, 1998.

MARTINS, Sérgio Pinto. Direito da Seguridade Social. $29^{\text {a }}$ ed. Editora Atlas, São Paulo, 2009.

MARTINS, Sérgio Pinto. Fundamentos de direito da seguridade social. 5. ed. São Paulo: Atlas, 2004. 
MASSONETO, Luís Fernando. O Direito Financeiro no Capitalismo Contemporâneo: a emergência de um novo padrão normativo. Tese de doutorado apresentada ao Departamento de Direito Econômico, Financeiro e Tributário da Faculdade de Direito da USP. São Paulo, 2006.

MATIJASCIC. Milko. Fundos de pensão e rearticulação da economia brasileira. Campinas: UNICAMP, 1994.

MAZZUCATO, Mariana. O Estado Empreendedor: desmascarando o mito do setor público vs. setor privado. Trad. Elvira Serapicos. $1^{a}$ ed. Portfólio-Penguin, São Paulo, 2014.

MEDAUAR, Odete. Serviços Públicos e serviços de interesse econômico geral. In MOREIRA NETO, Diogo de Figueiredo (coord.). Uma avaliação das tendências contemporâneas do direito administrativo: obra em homenagem a Eduardo García de Enterría. Renovar: Rio de Janeiro e São Paulo, 2003.

MEDEIROS, Marceli; SOUZA, Pedro H. G. F. de. Previdência dos trabalhadores dos setores público e privado e desigualdade no Brasil. Texto para Discussão $\mathrm{n}^{\circ} 1876$. IPEA. Brasília, 2013.

MELlO, Celso Antonio Bandeira de. Serviço Público e sua feição constitucional no Brasil. In MODESTO, Paulo e MENDONÇA, Oscar (orgs.). Direito do Estado: novos rumos. Tomo II. Max Limonad: São Paulo, 2001.

MORHY, Lauro (org.). Reforma da Previdência em questão. Editora UnB, 2003.

NASCIMENTO, Sergio. Entidades Abertas de Previdência Privada. In CORREIA, Marcus Orione Gonçalves (coord.) e VILLELA, José Corrêa (org.) Previdência Privada. São Paulo: LTr, 2004.

NUNES, António José Avelãs. Uma Introdução à Economia Política. São Paulo: Quartier Letin, 2007.

OFFE, Claus. A Democracia Partidária Competitiva e o "Welfare State” Keynesiano: fatores de estabilidade e desorganização. In OFFE, Claus. Problemas Estruturais do Estado Capitalista. Rio de Janeiro: Tempo Brasileiro, 1984.

OLIVEIRA, Francisco de. Crítica à razão dualista / O ornitorrinco. Boitempo Editorial, São Paulo, 2003.

OLIVEIRA, Francisco de. Os direitos do antivalor: a economia política da hegemonia imperfeita. Editora Vozes. Petrópolis, 1998.

ORNÉLAS, Waldeck. Desatando o nó da previdência. Senado Federal, Brasília, 2002.

PAIXÃO, Leonardo André; PINHEIRO, Ricardo Pena; CHEDEAK, José Carlos Sampaio. Regulação dos investimentos nos fundos de pensão: evolução histórica, tendências recentes e desafios regulatórios. In Revista de Previdência, n. ${ }^{\circ} 3$. Rio de Janeiro: Faculdade de Direito / UERJ, outubro de 2005. 
PAULANI, Leda M. A Autonomização das formas verdadeiramente sociais na teoria de Marx: comentários sobre o dinheiro no capitalismo contemporâneo. Revista Economia, vol. 12, n. 1, jan/abril 2011.

PAULANI, Leda Maria. Seguridade social, regimes previdenciários e padrão de acumulação: uma nota teórica e uma reflexão sobre o Brasil. In FAGNANI, Eduardo; HENRIQUE, Wilnês; e LÚCIO, Clemente Ganz (orgs.). Previdência Social: Como incluir os excluídos. LTr: São Paulo, 2008.

PEREIRA, Francisco; MIRANDA, Rogério Boueri; SILVA, Marly Matias. Os fundos de pensão como geradores de poupança interna. Texto para discussão 480, IPEA. Maio de 1997.

PIRES, Julio Manuel. Uma visão histórica sobre o problema do padrão de financiamento da economia brasileira. Ensaios FEE, Porto Alegre, v. 25, n. 2, pp. 545560, out. 2004.

POLANYI, Karl. A Grande Transformação: as origens da nossa época. Rio de Janeiro: Elsevier, 2000.

REDI, Maria Fernanda de Medeiros. Fundamentos da Regulação da Previdência Privada no Brasil. Tese de Doutorado em Direito Econômico apresentada na Faculdade de Direito da USP. São Paulo, 2004.

SAlGUES, Oto. Contratos de afretamento e transporte no Direito Marítimo. Jus Navigandi, Teresina, ano 8, n. 65, 1 maio 2003. Disponível em: $<$ http://jus.com.br/artigos/4022>. Acesso em: 14.12.2014.

SAUVIAT, Catherine. Os fundos de pensão e os fundos mútuos: principais atores da finança mundializada e do novo poder acionário. In: CHESNAIS, François (Org.). A finança mundializada. São Paulo: Boitempo, 2005.

SCHAPIRO, Mario Gomes. Novos Parâmetros para a Intervenção do Estado na Economia: persistência e dinâmica na atuação do BNDES em uma economia baseada no conhecimento. Tese de doutorado apresentada à Faculdade de Direito da USP. São Paulo, 2009.

SILVA, José Dirceu de Oliveira e. Uma necessidade de justiça social. In MARQUES, Rosa Maria et al. A previdência social no Brasil. Coleção Cadernos da Fundação Perseu Abramo n 2. Editora Perseu Abramo, São Paulo, 2003.

SOUTO, Vania Lucia Lins. Regulação e a supervisão do sistema de previdência complementar brasileiro: a análise do novo marco regulatório. Dissertação de Mestrado apresentada ao Departamento de Economia da Universidade de Brasília. Brasília, 2001.

SOUZA, Claudio Ferrer de. As Reformas da Previdência Social: uma análise comparativa dos sistemas de previdência social sob o aspecto das mudanças contemporâneas no atual cenário mundial. In CORREIA, Marcus Orione Gonçalves (coord.) e VILLELA, José Corrêa (org.) Previdência Privada. São Paulo: LTr, 2004. 
TAVARES, Marcelo Leonardo. Direito Previdenciário. 9a ed. Lumen Iuris, Rio de Janeiro, 2007.

TAVARES, Maria da Conceição e MIRANDA, José Carlos. Brasil: estratégias de conglomeração. In FIORI, José Luís. Estados, moedas e desenvolvimento. In FIORI, José Luís (org.). Estados e moedas no desenvolvimento das nações. $2^{\mathrm{a}}$ Ed. Petrópolis: Editora Vozes, 1999.

TORRES FILHO, Ernani Teixeira, e COSTA, Fernando Nogueira da. Financiamento de Longo Prazo no Brasil: um mercado em transformação. Revista Economia e Sociedade, 2012.

TRUBEK, David M. e SANTOS, Alvaro. The New Law and Economic Development: a critical appraisal. Nova York: Cambridge Press, 2006.

\section{Sítios Eletrônicos Institucionais}

AMÉRICA LATINA LOGÍSTICA <http://ri.all-logistica.com/>. Acesso em: 28.11.2014.

ASSOCIAÇÃO BRASILEIRA DAS ENTIDADES FECHADAS DE PREVIDÊNCIA COMPLEMENTAR <http://www.abrapp.org.br/>. Acesso em: 23.11.2014.

ASSOCIAÇÃO BRASILEIRA DE PRIVATE EQUITY E VENTURE CAPITAL <http://www.abvcap.com.br/>. Acesso em: 28.11.2014.

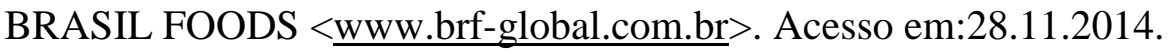

CAIXA DE PREVIDÊNCIA DOS FUNCIONÁRIOS DO BANCO DO BRASIL <www.previ.com.br>. Acesso em: 25.11.2014.

CAIXA ECONÔMICA FEDERAL <http://downloads.caixa.gov.br/>. Acesso em: 17.11.2014.

CONFEDERAÇÃO NACIONAL DOS TRABALHADORES EM EMPRESAS DE CRÉDITO <www.contec.org.br>. Acesso em: 14.12.2014.

CONSÓRCIO NORTE ENERGIA <www.norteenergiasa.com.br>. Acesso em: 28.11.2014.

FEDERAÇÃO DOS TRABALHADORES EM EMPRESAS DE CRÉDITO DO PARANÁ <http://www.fetecpr.org.br/>. Acesso em: 14.12.2014.

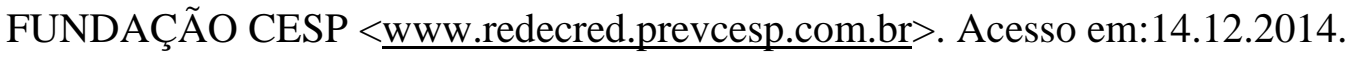

FUNDAÇÃO DOS ECONOMIÁRIOS FEDERAIS <http://www.funcef.com.br/>. Acesso em: 14.12.2014.

FUNDAÇÃO ITAÚ UNIBANCO < http://www.funcacaoitauunibanco.com.br/>. Acesso em 14.12.2014. 
FUNDAÇÃO PETROBRAS DE SEGURIDADE SOCIAL < http://www.petros.com.br/>. Acesso em: 25.11.2014.

INSTITUTO BRASILEIRO DE GEOGRAFIA E ESTATÍSTICA $<$ http://www.ibge.gov.br/>. Acesso em 23.11.2014.

INVEPAR <http://www.invepar.com.br/> . Acesso em 14.12.2014.

MINISTÉRIO DA PREVIDÊNCIA SOCIAL < http://www.previdencia.gov.br/>. Acesso em: 23.11.2014.

MINISTÉRIO DO TRABALHO E EMPREGO < http://portal.mte.gov.br>. Acesso em 17.11.2014.

PROGRAMA DE ACELERAÇÃO DO CRESCIMENTO < http://www.pac.gov.br $>$. Acesso em: 28.11.2014.

RECEITA FEDERAL DO BRASIL <http://www.receita.fazenda.gov.br >. Acesso em 04.05.2014.

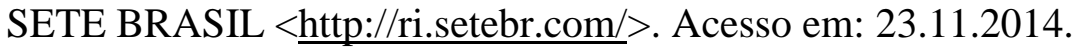

VALE < http://www.vale.com/>. Acesso em: 14.12.2014.

VALOR DA LOGÍSTICA INTEGRADA <http://www.vli-logistica.com/ptbr/conheca>. Acesso em: 28.11.2014.

\section{Sítios Eletrônicos de Periódicos e Agências de Notícias}

AGÊNCIA BRASIL < www.memoria.ebc.com.br $>$. Acesso em 23.04.2014.

JORNAL FOLHA DE SÃO PAULO <http://www1.folha.uol.com.br/>. Acesso em 14.12.2014.

JORNAL O ESTADO DE SÃO PAULO < http://www.estadao.com.br/>. Acesso em: 14.12.2014.

JORNAL VALOR ECONÔMICO <http://www.valor.com.br/>. Acesso em: 26.11.2014.

REVISTA ÉPOCA <http://revistaepoca.globo.com/>. Acesso em: 30.11.2014.

REVISTA EXAME < http://exame.abril.com.br/> . Acesso em: 30.11.2014.

REVISTA ISTOÉ < http://www.istoe.com.br/> . Acesso em: 30.11.2014.

REVISTA PIAUÍ <http://revistapiaui.estadao.com.br/> . Acesso em: 30.11.2014.

UNIVERSO ONLINE < http://noticias.uol.com.br/> . Acesso em: 14.12.2014. 